\title{
The Assassination of Jacques Lemaigre Dubreuil
}

This is a fascinating study of a forgotten patriot - now ranked as a national hero in Morocco-who struggled to realise his vision for France and North Africa amidst the turmoil of mid-twentieth century social unrest, war, defeat and occupation, resistance and liberation, and postwar decolonization

The French industrialist and political activist Jacques Lemaigre Dubreuil (1894-1955) was:

- $\quad$ president of the Taxpayers' Federation in the 1930s;

- entrepreneur in wartime France and Africa;

- $\quad$ organizer of the 'Group of Five' in Algiers which prepared for the Allied landings in North Africa (November 1942);

- ' inventor' of General Henri Giraud as a candidate for the leadership of liberated North and West Africa;

- negotiator of the Murphy-Giraud Agreements and the Anfa Memorandum with President Roosevelt (1942 and 1943);

- $\quad$ political writer on the postwar future of France in Morocco;

- the owner of the liberal newspaper Maroc-Presse.

His assassination in Casablanca by French counter-terrorists in June 1955 was a 'turning point' event which pushed the French government to grant independence to Morocco. Was he a rabble-rouser, a demagogue, a betrayer of French interests at home and overseas or a reformer, a patriot, a hero of the anti-German resistance, and a champion of Franco-Moroccan solidarity? Written by a prize-winning author, this story is of great interest to students and researchers in modern French and Moroccan history, French Colonial history, African history, Islamic history and politics.

William A. Hoisington, Jr is Professor Emeritus of Modern European and French Colonial History at the University of Illinois at Chicago. He has published widely, and is the author of two prize-winning books on the history of French imperialism in North Africa, The Casablanca Connection: French Colonial Policy, 1936-1943 and Lyautey and the French Conquest of Morocco. 


\section{History and society in the Islamic world \\ Edited by Anoushiravan Ehteshami \\ University of Durham and George Joffé Centre \\ for International Studies, Cambridge University \\ ISSN: $1466-9390$}

Contemporary events in the Islamic world dominate the headlines and emphasize the crises of the Middle East and North Africa, yet the Islamic world is far larger and more varied than we realize. Current affairs there too mask the underlying trends and values that have, over time, created a fascinating and complex world. This new series is intended to reveal that other Islamic reality by looking at its history and society over the ages, as well as at the contemporary scene. It will also reach far further afield, bringing in Central Asia and the Far East as part of a cultural space sharing common values and beliefs but manifesting a vast diversity of experience and social order.

French Military Rule in Morocco

Colonialism and its consequences

Moshe Gershovich

Tribe and Society in Rural Morocco

David M. Hart

North Africa, Islam and the Mediterranean World

From the Almoravids to the Algerian War

Edited by Julia Clancy-Smith

The Walled Arab City in Literature, Architecture and History

The living Medina in the Maghrib

Edited by Susan Slyomovics

Tribalism and Rural Society in the Islamic World

David M. Hart

Technology, Tradition and Survival

Aspects of material culture in the Middle East and Central Asia

Richard Tapper and Keith McLachlan

\section{Lebanon}

The politics of frustration - the failed coup of 1961

Adel Beshara

Britain and Morocco During the Embassy of John Drummond Hay

Khalid Ben Srhir 


\section{The Assassination of Jacques Lemaigre Dubreuil}

A Frenchman Between France and North Africa

William A. Hoisington, Jr.

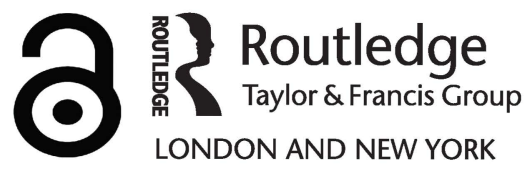


First published 2005 by Routledge

Published 2017 by Routledge

2 Park Square, Milton Park, Abingdon, Oxon OX14 4RN

711 Third Avenue, New York, NY 10017, USA

Routledge is an imprint of the Taylor \& Francis Group, an informa business

Copyright (c) 2005 William A. Hoisington, Jr.

Professor Emeritus of Modern European and French Colonial History

University of Illinois at Chicago

Chicago, Illinois, USA.

Typeset in Times New Roman by Bookcraft Ltd, Stroud, Gloucestershire

The Open Access version of this book, available at www.tandfebooks.com, has been made available under a Creative Commons Attribution-Non Commercial-No Derivatives 4.0 license.

British Library Cataloguing in Publication Data

A catalogue record for this book is available from the British Library

Library of Congress Cataloging in Publication Data

A catalog record for this book has been requested

ISBN13: 978-0-415-35032-7 (hbk)

ISBN13: 978-0-415-58946-8 (pbk)

\section{Publisher's Note}

The publisher has gone to great lengths to ensure the quality of this reprint but points out that some imperfections in the original may be apparent. 
To the memory of Jean-Pierre Lemaigre Dubreuil 


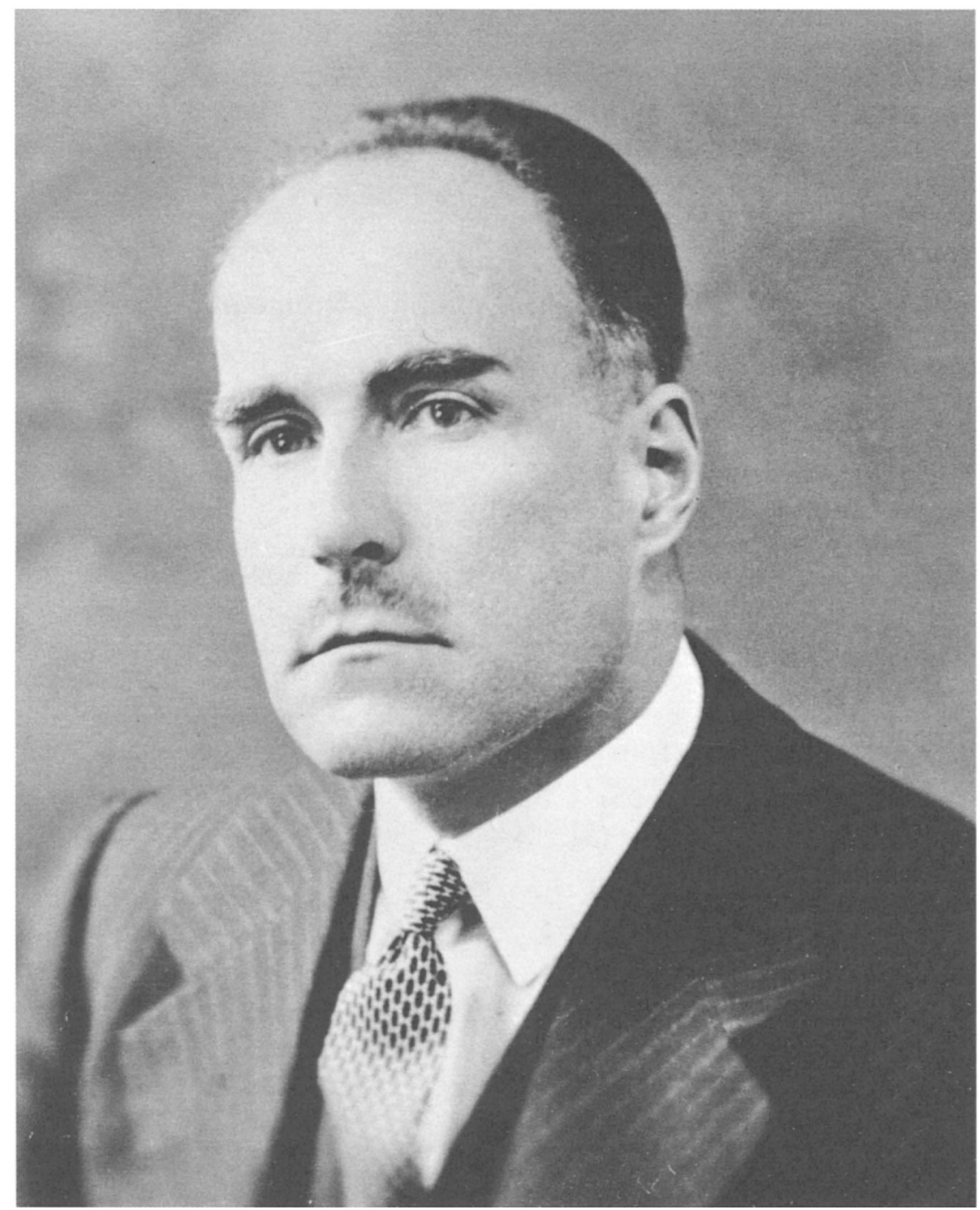

Jacques Lemaigre Dubreuil (Collection Roger Viollet) 


\section{Contents}

List of plates viii

Acknowledgements $\quad$ ix

Preface xi

1 Taxpayer revolt in France 1

2 France's fall and the Vichy change 45

3 Defending French Africa 60

4 Working for Giraud 82

5 To die in Casablanca $\quad 99$

$\begin{array}{ll}\text { Conclusion } & 138\end{array}$

$\begin{array}{ll}\text { Notes } & 141\end{array}$

Bibliography 169

Index 177 


\section{Plates}

Jacques Lemaigre Dubreuil

1 'A la porte les exploiteurs,' January-February 1936

2 'Contribuables!,' 1936,

3 'Le désastre,' July-August 1937

4 'Contribuable souviens-toi ...,' February 1938

5 'Les Pantins!,' June 1938

6 'Une victoire des contribuables parisiens,' January 1939

7 'Arrêtez les voleurs,' October-November 1938
Frontispiece

23

25

31

35

37

40

43 


\section{Acknowledgements}

I am grateful to the late Gordon Wright of Stanford University, a lucid interpreter of French history who could turn even the writing of a textbook into an art form, for first suggesting this project to me. And to my friends and colleagues who listened to and commented on parts of this text in its various stages of development over the years, especially the late William B. Cohen of Indiana University at Bloomington, French colonial historian 'sans peur et sans reproche,' and Arthur Layton Funk of the University of Florida at Gainesville, the only historian I know who in the course of his own work on France and America during the Second World War met and interviewed Lemaigre Dubreuil. Sharon Leigh Hoisington encouraged me to keep on this research trail despite the interruptions of other writing projects and we will never forget the generous hospitality of the Lemaigre Dubreuil family in Paris, Rabat, and Casablanca. Finally, I am ever and always indebted to my three daughters for their unflagging interest in and enthusiasm for my work.

I dedicate this book to the memory of Jean-Pierre Lemaigre Dubreuil who made his father's papers available to me and by so doing introduced me to the contours of the political life of a passionate and determined individual.

The author and publishers would like to thank the following for permission to reprint material previously published in article form: The University of Chicago Press for 'The Struggle for Economic Influence in Southeastern Europe: The French Failure in Romania, 1940,' Journal of Modern History, 43, 3 (September 1971); Alfred University for 'Toward the Sixth of February: Taxpayer Protest in France, 1928-1934,' Historical Reflections/ Réflexions historiques, 3, 1 (Summer 1976); Sage Publications Ltd for 'Commerce and Conflict: French Businessmen in Morocco, 1952-55,' Journal of Contemporary History, 9, 2 (1974); L'Express and Chantal Blondeau for permission to reproduce the cover of L'Express (June 18, 1955); and Roger Viollet for permission to reprint the late-1930s photograph of Jacques Lemaigre Dubreuil used as the frontispiece.

Every effort has been made to contact copyright holders for their permission to reprint material in this book. The publishers would be grateful to hear from any copyright holder who is not here acknowledged and will undertake to rectify any errors or omissions in future editions of this book. 



\section{Preface}

'Et comme toujours ce sont les meilleurs qui tombent, et le pays vient de perdre un grand Français.'

'It is always the finest who fall, and once again our country has lost a great Frenchman.'

Alphonse Juin, Maréchal de France

'Les Français du Maroc et les Marocains peuvent également s'enorgueillir du nom de Jacques Lemaigre Dubreuil. C'est beaucoup, pour sceller l'amitié de deux peuples, que d'avoir les mêmes martyrs.'

'The Frenchmen of Morocco and the Moroccans themselves can take equal pride in the name of Jacques Lemaigre Dubreuil. To seal a friendship between two peoples it is important to have the same martyrs.'

François Mauriac, de l'Académie Française

The assassination of Jacques Lemaigre Dubreuil in Casablanca in June 1955 was a turning point in modern Moroccan history, speeding up the process of colonial independence much as the murder of Dr Émile Mauchamp in Marrakech almost 50 years earlier had triggered quite the opposite action - the French occupation of Oujda which was the prelude to the French protectorate of 1912. ${ }^{1}$ Matters Moroccan occupy a large part of this text, but so do matters French and North African. This explains the title of my book.

Jacques Lemaigre Dubreuil presided over the vegetable-oil firm of Georges Lesieur et ses Fils of Dunkirk ('L'Huile Lesieur transforme les plats les plus simples en régals délicieux,' 1938). In the 1930s he headed the Taxpayers' Federation, a noisy citizen anti-tax group, was an elected member of the Bank of France, and owned the Paris newspaper, Le Jour-Écho de Paris. During the Second World War he transferred Lesieur factories from devastated and German-occupied France to French Africa (Algiers, Casablanca, Dakar) and conspired with American diplomatic agents to prepare for the Allied landings in North Africa in November 1942, 'inventing' General Henri Giraud as a rival to the austere, uncompromising Charles de Gaulle along the way. After the war he made Casablanca his North African headquarters and worked to resolve the political disputes that put France and the Sultan of Morocco at odds. Until his death, his newspaper articles in Le Monde 


\section{xii The assassination of Jacques Lemaigre Dubreuil}

(and his purchase of the Casablanca daily Maroc-Presse) made him a leader of French 'liberals' determined to end Moroccan 'terrorism' (and the French 'counter-terrorism' that paralleled it) which accompanied the forced exile of Sultan Sidi Mohammed Ben Youssef in August 1953 and to create a new FrancoMoroccan partnership.

Someone once called Lemaigre Dubreuil a 'born conspirator' and his life has elements that would fit a spy novel or a screen thriller. ${ }^{2} \mathrm{He}$ walked the streets of wartime Casablanca while Humphrey Bogart and Ingrid Bergman were practicing their lines for Casablanca (1942) on a Hollywood sound stage. And Alfred Hitchcock filmed his 1956 classic The Man Who Knew Too Much in Marrakech the month before Lemaigre Dubreuil died in a hail of machine-gun bullets. ${ }^{3}$ Was he a rabble-rouser, a demagogue, a betrayer of French interests at home and overseas or a reformer, a patriot, a hero of the resistance, and a champion of Moroccan independence?

Chapter 1 introduces the French taxpayer movement of the 1930s, then centers on Lemaigre Dubreuil's presidency of the Taxpayers' Federation between 1935 and 1940. Chapter 2 describes Lemaigre Dubreuil's wartime mission to Romania (1940), his purchase of Le Jour-Écho de Paris, and his transfer of Georges Lesieur et ses Fils to French Africa. Chapters 3 and 4 view Vichy France and the war years from Algiers, emphasizing Lemaigre Dubreuil's role in securing the political agreements that preceded the Allied landings in North Africa, then as an adviser to General Giraud. Chapter 5 details Lemaigre Dubreuil's work in Morocco, especially his political writing, culminating with his assassination in June 1955.

All his life Jacques Lemaigre Dubreuil was plagued with a hyphen Lemaigre-Dubreuil - that he did not want. In the end he accepted it, even from the copy editors of the newspapers he owned and managed. Here, however, he will get what he wanted, a hyphen-free name spelled as he and the members of his family wrote it. 


\title{
1 Taxpayer revolt in France
}

\author{
'Contribuables, réveillez-vous!' \\ 'Taxpayers, wake up!'
}

Le Réveil du contribuable, April 1931

\section{Toward 6 February}

The Taxpayers' Federation was the creation of Louis-Alphonse Large, an enterprising small-town auditor from east-central France, who set up a Taxpayer Defense League, the Ligue de Défense des Intérêts du Contribuable, in 1921. Three years later, in 1924, he began mailing a newsletter from Paris (where he now headed the accounting department of Maison Lamoesse Frères) entitled Défendre, filled with suggestions for the harried taxpayer. In November 1928, together with journalist Auguste Cavalier of the conservative L'Intérêt français, and Paris businessman Charles Kula, Large established the National Taxpayers' Federation, the Fédération Nationale des Groupements et Syndicats des Contribuables, with the financial support of perfume manufacturer François Coty. Cavalier and Kula were committed to taxpayer organization and action; Kula believed that France was 'collapsing under the weight of excessive taxation' and had founded his own taxpayer group, the Confédération Générale des Contribuables, early in 1928 as a symbolic counterweight to the power of organized labor and the political groups of the Left which he said were leading France to 'moral and economic ruin.' Coty yearned for a public role. He owned the Paris newspaper Le Figaro, launched the mass circulation daily L'Ami du peuple in 1928, and generously subsidized organizations of a conservative persuasion; he founded and presided over the veterans' organization, the Croix de Feu, and in 1933, he formed his own political group, the Solidarité Française. ${ }^{2}$

It is not difficult to account for this flurry of taxpayer activity, given France's tax history and its postwar economic problems. The battle over an income tax had preoccupied the Chamber of Deputies for 40 years and although it did not rival the Dreyfus Affair in sound, fury, or passion, it made active combatants out of usually passive citizens. The tax was finally adopted in 1913 as an emergency national defense measure. Nevertheless, with the exception of the income tax, the French tax system in 1919 was virtually identical to that which had been created by the governments of the French Revolution. Out of touch with the 


\section{The assassination of Jacques Lemaigre Dubreuil}

contemporary realities of wealth and income, taxes in France were inequitable and inelastic, a mockery of the democratic ideal and woefully inadequate to cope with the financial needs of the Third Republic in the third decade of the twentieth century. Still, rather than recast the tax system, French political leaders counted on German reparations and even American loans to provide required revenues. This was not to be. The wrangling over war debts, reparations, and international loans lasted a full decade after the end of the Great War and France was none the richer for it. As a result, taxes had to increase. And they climbed steadily during the 1920s, perhaps most dramatically in 1924 with Premier Raymond Poincaré's 20 percent across-the-board increase, a levy which the middle-income taxpayer, especially the small businessman and investor, considered harsh. At the same time a persistent inflation and the devaluation of the currency robbed Frenchmen of the value of their savings and destroyed the worth of government bonds and private securities. $^{3}$

Unfortunately, taxation also became connected with the social struggle in France. Champions of the income tax such as Socialist Jean Jaurès, for example, saw it as a way to redistribute national wealth, furnishing 'new means of action to the workers. ${ }^{4}$ Opponents of the tax such as the Association for the Defense of the Middle Classes viewed it as a knife at the throat of the bourgeoisie. ${ }^{5}$ The sales tax, adopted in 1920 in order to produce a steady, easily collectible flow of revenue to the state which would adjust automatically with prices, also created an ideological battlefield even though the adversaries disagreed on its effect: the Left argued that it discriminated against the poor whereas the Right complained that it taxed business unfairly. ${ }^{6}$ Taxes were regarded as weapons in a class conflict rather than as instruments for raising national revenue. And this was precisely how the Taxpayers' Federation saw them. 'Excessive taxation has created divisions [among Frenchmen] ... Not since the end of the hostilities have Frenchmen fought so much! Economic war and social hatred have replaced the hatred of the invader."7

Predictably, the National Taxpayers' Federation drew its support from those conservative middle sectors in French society which saw high taxes and government spending as the root causes of France's economic crisis and the organization of the classes moyennes as the sine qua non of class survival and national salvation. 'We want ... substantial economies,' demanded Baron Albert d'Anthouard de Wasservas, a former minister to Brazil and the federation's first president. 'We want the state to reduce its expenses instead of spending money recklessly. We want those who ... are the guardians of these expenditures to stop pushing toward extravagance.' D'Anthouard insisted that much of the money paid to the government went for 'an army of civil servants' which was little more than a political instrument to be used at election time. And he admitted that in part the taxpayers had organized to oppose the civil servants' union, the Confédération Générale des Fonctionnaires. However, this was not the federation's main purpose. 'We want the financial forces of the nation ... to be used to their maximum effectiveness and developed rationally. Our aim, our only aim, is to make France more prosperous, to allow its inhabitants to enjoy more comfort and security. However, 
we protest the disorder which invades our public finances and rips at the fabric of our national life because it engenders anarchy and ruins the general economy. The abuses of the tax system are unacceptable because they destroy family, property, and production, and by reducing the birthrate prepare our country for its ruin and destruction."

Such sentiments won the ringing endorsement of traditional bourgeois agricultural, commercial, and professional groups such as the Société d'Agriculteurs de France, the Association des Viticulteurs de France, the Syndicat Général du Commerce et de l'Industrie, the Fédération des Commerçants-Détaillants de France, the Union de la Propriété Bâtie de France, the Chambre Syndicale des Propriétés Immobilières de la Ville de Paris, the Fédération des Porteurs de ValeursMobilières, the Chambre des Avoués, and the Fédération des Architectes de France. They were joined by those concerned with the interests of women and the family, the Action Sociale de la Femme, the Société pour l'Amléioration du Sort de la Femme, and the Alliance Nationale pour l'Accroissement de la Population Française as well as others interested in national economic development such as the Union des Grandes Associations Françaises pour 1'Essor National. ${ }^{9}$

It was from organizations such as these that the federation drew its leaders. From 1928 to 1934 the governing board (comité d'action) included president d'Anthouard, landowner [agriculteur] from the Haute-Loire; vice-presidents Paul Lefaivre, landowner (Seine), Édouard Ferrasse, lawyer and winegrower (Hérault), Claude Gaillard, architect (Rhône), Alfred-Joseph Colmart, landowner (Marne); delegate-general Louis Large, journalist (Seine); secretary-general Paul Lefebvre, lawyer (Seine); treasurer Arthur Denuit, notary (Seine); and members Georges Barthet, pharmacist (Seine), Jacques Buisson, businessman [industriel] (HauteGaronne), Gustave Durandeau, businessman (Gironde), Georges d'Hattecourt, landowner (Maine-et-Loire), Georges Mongelard, merchant [commerçant] (Gard), Jean Pequin, retired Forests and Waterways inspector (Charente-Inférieure), Frédéric Saucet, avoué (Haute-Garonne), Georges Segalen, merchant (Loire-Inférieure), François Tillet, merchant (Rhône), Amedée Vallée, insurance representative (Ille-etVilaine), and Marquis Aymar Davy de Virville, landowner (Mayenne). ${ }^{10}$

But the federation aspired to represent a much larger constituency in middleclass France. It sought to rally those among the artisans, shopkeepers, merchants, small businessmen, professionals, and property owners who had been most seriously affected by the economic crisis and who sought a remedy for present and future hardships, those for whom economic questions now took precedence over political ones. 'There are no reds or whites or pinks in the federation and whether the government is royalist, radical, or socialist makes little difference to us. What we want is tax relief. We simply ask for the end of waste, fraud, and the spoils of office. ${ }^{11}$ The non-partisan stance was somewhat forced, since the federation blamed the trade unions and the parties of the Left for France's difficulties, but it was not entirely disingenuous. Kula was ousted from the federation in 1930 for what d'Anthouard considered intemperate statements about the responsibility of the unions, the Radical-Socialist party, and freemasonry for France's decline. $^{12}$ 


\section{The assassination of Jacques Lemaigre Dubreuil}

The federation was headquartered in the ninth arrondissement at 24 rue de Clichy (and later nearby at 22 rue LaFayette). Large was the delegate-general responsible for the federation's day-to-day operation and its monthly journal, Le Réveil du contribuable, and Baron d'Anthouard presided over the federation's governing board which oversaw the work of the federation. The board, elected by a central committee, had a membership of twenty-four, each member serving a three-year term, staggered so that eight seats were renewed every year. The central committee of about 100 members was composed of the representatives of departmental federations formed by local and municipal taxpayer unions and groups. The central committee met once a year to review the federation's activity and to discuss and vote on federation reports, committees, and programs. Funds for the national federation were provided by the departmental federations, which contributed 20 percent of their annual receipts to Paris, and the affiliated social, corporative, and professional groups, which supplied the federation with as much money as they could spare. This was never a satisfactory arrangement. In November 1930, the treasurer revealed that the federation existed only through the generosity of the members of the governing board; a year later, however, there was a budget surplus of 4400 francs. But in November 1933, the federation reported a deficit of 35,000 francs. There was, of course, the guardian angel, François Coty, but even before he founded Solidarité Française which took enormous amounts of his time and money he had become less interested in the fortunes of the federation. Le Réveil $d u$ contribuable lived a separate life; it was supported by advertising and subscriptions of six francs a year. ${ }^{13}$

In December 1931 d'Anthouard announced that the federation had 'nearly 700,000 individual members' and the support of 'more than 150 associations of corporative, syndical, and social defense, of veterans and war victims, and of victims of the depreciation of the franc.' When tallied up, this gave the federation the backing of 'about five million taxpayers. ${ }^{\text {'1 }}$ Undoubtedly these were exaggerated estimates. Yet there appear to have been no paper committees. The member groups of the federation, however small some may have been, did exist, met, carried out the work of organization and propaganda, and in many cases had remarkable success in persuading the public authorities to act on their recommendations. They took credit for the reduction of municipal taxes in towns scattered across France (Alès, Carpentras, Decize, Dunkirk, Libourne, Montignac, Nevers, Pau, and Toulon) and departmental taxes in the Bouches-du-Rhône, Nièvre, Saône-et-Loire, and Vienne. ${ }^{15}$ As a member of the governing board confidently remarked: 'The taxpayer unions constitute an important, disciplined, active unit. It is true that they are only a minority, but they contain an intelligent elite (élite réflechie) whose decisions are capable of influencing the voting public by educating them. ${ }^{, 16}$

In general the federation desired to introduce economy into the management of the public funds of the state, of the departments, and of the communes; to increase governmental efficiency; to restore the activity and the rights of private initiative; to establish a tax court; and to revise the tax laws to provide for a more 'equitable' distribution of the tax burden. ${ }^{17}$ It suggested specific measures as well: a single basic deduction on the income tax (abattement à la base unique) 
for all categories of taxpayers; the repeal or modification of the business licensing tax (the patente); the reduction of taxes on motor vehicles, on stocks and bonds, on property transfers, and inheritances; the repeal of the sales tax (taxe sur le chiffre d'affaires); and tax relief for large families. ${ }^{18}$ Most of these reforms were geared to help the propertied, business-oriented middle class.

In 1930 a major issue of concern to the taxpayers was the law on social insurance which compelled employers in agriculture, commerce, and industry to contribute to a national social security fund. The federation called it a 'disaster' for the entire country, an indirect tax on all the productive forces of the nation. ${ }^{19}$ Henri Dorgères, editor of Le Progrés agricole de l'Ouest of Rennes and the aggressive leader of Peasant Defense, Défense Paysanne, the farmer defense group of western France, claimed that social insurance cost the taxpayers four billion francs a year; he characterized it as 'the best scheme that democracy has yet devised to take money from the pockets of the taxpayers and put it into the hands of the bureaucrats. ${ }^{20}$ The federation formed a Front Unique Contre les Assurances Sociales to fight for the law's modification or repeal, and this brought the taxpayers and the farmers together in a common cause. ${ }^{21}$ Boisterous anti-government rallies at Rennes (20,000 in attendance), Lisieux (6000), Caen $(12,000)$, Angers $(15,000)$, and Chartres in the spring of 1932 gave this protest nation-wide attention. ${ }^{22}$ For a while at least, taxpayer hatchets ('to chop away at the forest of abuses') and farmer pitchforks were wielded in unison. The cooperation was not surprising. Farmers in western France were angry about the collapse of agricultural prices which in 1930 were down 28 percent from the 1928 levels and which continued to drop through the mid-1930s. Dorgères blamed the government for the lack of a 'firm and coherent' agricultural policy and complained incessantly about the heavy farm tax burden. ${ }^{23}$ And the Taxpayers' Federation was impressed with the large crowds at Dorgères's meetings as well as the farmer commitment to direct action against the government. Moreover, federation leaders (in truth, as most Frenchmen) had a strong sentimental attachment to peasant France. They lamented the decline of agricultural and artisan industries, endorsed the family vote to encourage the expression of rural views, and opposed the ongoing industrialization of the cities which drew the farm population from the land. ${ }^{24}$

Discontent with parliamentary government was mingled with the taxpayers' protest. Since they figured that the politicians had created their problems, how could they look to them for solutions? 'Our elected officials are in the majority the opponents of the taxpayers; they are preoccupied with taking care of themselves, with ensuring their own re-election, and with satisfying only their most influential voters ...; they are professional politicians first and foremost, unconcerned with the needs of the country and ... with its problems ... ${ }^{25}$ Still, d'Anthouard insisted that the taxpayers were not 'in principle adversaries of either the government, or parliament, or any departmental or municipal assembly; on the contrary it is by cooperating with the public authorities and through the use of legitimate pressure that we can help them perform their difficult task ...' ${ }^{26}$ 'Our only goal is to see that those who pay the taxes are listened to ...' ${ }^{27}$ But there was a warning as well. Should government refuse to heed them, the taxpayers would fight: '... we will 


\section{The assassination of Jacques Lemaigre Dubreuil}

oppose all those elected officials, whatever their political affiliation, who disregard our grievances. ${ }^{28}$ And among their weapons was the tax strike, first hinted at by Large in his report to the federation's second congress in 1930, and then openly endorsed by the federation at its third congress in 1931 as one 'means of action' to force the government to reduce the national budget and to alleviate the taxpayers' burden. ${ }^{29}$

Persuasion, however, was the federation's preferred tactic. In a radio broadcast from Paris in January 1932, d'Anthouard outlined the federation's program and listed the more than sixty organizations which had approved it. The purpose was two-fold: to publicize the federation and to prove to the government that it was a valid spokesman for taxpayer France. Moreover, the groups named indicated that the federation had indeed broadened its base of support. Small independent merchants and businessmen had responded to the federation's appeal. ${ }^{30}$ In addition, the endorsement of veterans' organizations - the Légion des Combattants Français, the Fédération Nationale des Anciens Combattants, and the Croix de Feu - which were powerful interest groups in inter-war France, gave a serious, militant, and patriotic tone to d'Anthouard's declaration.

Since 1932 was an election year in France, the federation urged the spring parliamentary contestants to accept its program or lose taxpayer support. 'Be merciless, but fair toward all the candidates,' counseled Le Réveil du contribuable. It was an uncomfortable list of demands to present to candidates for the Chamber of Deputies because the taxpayers wanted to deprive the Chamber of the right to introduce financial legislation in order to check 'parliamentary demagoguery,' to reduce the number of seats in the Chamber, and to cut the number of civil servants everywhere. ${ }^{31}$ Surprisingly, there was an encouraging response. The conservative Fédération Républicaine incorporated the taxpayers' complaints into its election platform. Prime Minister André Tardieu, one of France's few inter-war reformers, renewed his public promise for economy in government. ${ }^{32}$ And of the deputies elected to the Chamber, over seventy pledged to support the taxpayers' program, among them many who would find notoriety in the 1930s and beyond, such as René Coty (Républicain de Gauche, Seine-Inférieure), Jean Goy (Radical Independent, Seine), Pierre Mendès France (Radical-Socialist, Eure), and Xavier Vallat (Independent, Ardèche) ${ }^{33}$ The federation credited itself with bringing the taxpayers' cause to the attention of all the candidates, forcing some unfriendly deputies into run-off elections (and in certain cases of aiding in their defeat), and increasing citizen awareness of the federation's work. ${ }^{34}$ In the new Chamber the Group for the Protection of Taxpayer Interests had a membership of $217 .^{35}$

Unfortunately, election promises were forgotten in the business of forming a government. The Radical-Socialist party, whose views on the need for a balanced budget were in harmony with those of the federation, finally formed a partnership with the Socialists; this meant that no stern deflationary plan would be adopted. In fact, the legislative session accomplished little of importance because of the basic difference of opinion between the coalition partners in financial matters. And eventually finances destroyed the coalition. To make matters worse, even the government leaders whom the taxpayers had counted among their friends, such as 
Finance Minister Joseph Caillaux, were somewhat annoyed at the federation's meddling in politics. ${ }^{36}$ Presumably the politicians had all they could handle without bourgeois pressure groups raising a fuss.

New federation directives were issued for the future action of the taxpayers: meetings would be sponsored in cooperation with 'the greatest possible number of corporative and professional organizations,' and payment of taxes held back until 'the last limit imposed by law, using ... every delay and every legal means. ${ }^{37}$ Legal resistance to taxation was only a step away from a tax strike. 'Those subject to taxation,' d'Anthouard stated, 'must be ready for anything. At a given signal they must be prepared to put the tax strike into operation.' But the federation hesitated. Large explained that the strike was 'an extremely dangerous revolutionary action,' requiring 'careful planning, based on indispensable education.' $\mathrm{He}$ reported that at this time the federation was unready to commit itself to a strike, so the most it would do in June 1932 was to endorse the principle of legal resistance to taxation. ${ }^{38}$

By October things had changed. Parliament had approved tax increases during the summer and the federation's preparations were completed. At a Paris meeting attended by 2000 citizens federation leaders announced the strike. 'Not a total strike,' Large explained. 'We are not revolutionaries. We know that the state needs money ... We have no intention of making it impossible to govern. But since the government is ruining both itself and us, we must force it to reduce its expenditures by refusing to pay a part of the taxes that are crushing us.' Joined by representatives of Peasant Defense, the Comité du Salut Économique, the Union Nationale des Combattants, the Légion des Combattants Français, and the Jeunesses Patriotes, the taxpayers agreed that the 'partial' tax strike would apply to the taxes of 1932 and 1933. 'Those who govern us must finally realize ...,' so Dorgères told the crowd, 'that we have had enough ... C'est fini! We will not be the eternal suckers. ${ }^{39}$

The federation now began to draw larger crowds and to catch the interest of the political leagues whose leaders recognized the potential of a rightist taxpayer revolt. At the Magic-City meeting hall 3500 Parisians listened to Large and d'Anthouard denounce parliament and call for a non-partisan taxpayer coalition. 'The time has come to group together all the solid elements of the nation under the taxpayer banner without regard to considerations of personal interest or political party. We have had enough of the false promises with which our politicians fill us. We no longer have confidence in our political leaders and we are here today to let them know that we have decided to impose our will.' After the speech-making, Large invited the audience to march to the Chamber of Deputies, the Senate, and the Élysée Palace as a show of taxpayer strength and determination. Although police barricades made a mass march impossible by dividing the crowd as it left the hall, 200 members of the royalist Action Française's Camelots du Roi rallied some of the taxpayers and began the move on the Chamber. Repeated police interventions dispersed the group five blocks from Magic-City at the Pont de l'Alma. Police actions with the taxpayers and Camelots were also reported at Place de l'Alma, avenue Marceau, avenue Pierre Ier, and rue Pierre Charron on the right bank and rue Malar, rue Surcouf, and rue Cognacq-Jay on the left bank. In all 
sixteen arrests were made. ${ }^{40}$ It was the taxpayers' initiation into the growing fraternity of Frenchmen who were taking their protest into the streets.

An ambitious national publicity campaign followed the Paris meeting of 28 January, culminating on 19 March - 'National Taxpayers' Day' - with meetings and marches in 46 provincial cities. At these rallies federation spokesmen called for a balanced budget, economy in government, administrative reform, and the establishment of a 'government of authority,' alone capable of returning order to public affairs. Following the meetings the taxpayers marched to the prefecture or the town hall. The largest crowds were in western France at La Roche sur Yon (14,000 in attendance), Angers (10,000), and Caen where a morning rally drew 4000 citizens, mostly farmers, and an afternoon meeting, attended by some members of parliament, attracted 11,000. The smallest gathering at Soissons had 250 people. Most meetings were calm and orderly: Laval (5500), Nevers (5000), Châteauroux (4000 'mostly farmers'), Rochefort (3000), Poitiers (2000), Évreux (1500), Melun (1200), Versailles (1100), Corbeil (1000), Beauvais (1000), Agen (800), Toulouse (700), Le Puy (700), Montpellier (700), Saint-Brieuc (500), Meaux (500), Besançon (500), Cherbourg (500), and 'several hundred' at Libourne, Pau, Nîmes, Mâcon, and Annency. At Nîmes, Montpellier, and Cherbourg there was a holiday atmosphere and automobiles decorated with protest posters paraded through the streets of the cities. ${ }^{41}$

Disturbances occurred at nine meetings. According to police reports, groups belonging to 'political and union formations of the Left and extreme Left' disrupted the Saint-Quentin (2000) rally: fighting broke out and 'Communists' took over the speaker's platform. 'Extremists' prevented any votes on taxpayer resolutions at Tours (1800). At Châtellerault (1250) there was a 'stormy' meeting during which 'Socialists' shouted their replies to taxpayer speakers, seized the rostrum several times, and chanted the 'Internationale.' At Houilles (3000) two members of parliament of the 'extreme Left' tried to respond to the federation orators which resulted in a shouting match. At Nantes (6000) leftists tried to drown out the speakers, forcing the police to evacuate the hall to avoid any incident; among those attending the gathering were 'a certain number of Camelots du Roi and members of the Jeunesses Patriotes.' 'Socialists' and members of the parties of the 'extreme Left' sabotaged the Reims meeting (4000) which had to be dismissed before it was over; similar 'Leftist' and 'extreme Left' disruption caused the early termination of the Troyes (400) meeting. On the other hand, at Angoulême (2500) the taxpayers took the initiative and surrounded the prefecture, shouting 'hostile cries' at the prefect; and at Rennes (6000) a taxpayer march which included 'farmer militants' was stopped by the Garde Mobile and about twenty marchers were arrested. ${ }^{42}$

According to police estimates, the 'National Taxpayers' Day' had involved about 100,000 citizens and represented 'an enormous propaganda effort among shopkeepers, businessmen, artisans, farmers, and veterans. ${ }^{43}$ Federation leaders admitted that the response was far greater than they had hoped for. ${ }^{44}$ But opponents of the federation claimed to be unimpressed. Based on reports from the Reims and Tours meetings, Le Peuple, the official journal of the Confédération Générale du 
Travail, dismissed the federation as 'a small group trying to stir up fascist agitation in France. ${ }^{45}$ The Socialist newspaper Le Populaire saw things in a similar way. ${ }^{46}$ On the other hand, the Communists sided ' ... with the taxpayers, the shopkeepers [and] the peasants who are struggling against the tax burden, [and] who ask that it be alleviated.' But they condemned the federation and its leaders: 'Reject your bad shepherds: the fascist grands bourgeois, the large landowners, the sellers of fertilizer and machinery, the directors of large commercial enterprises with multiple branches, the expropriators of small commerce. They are your enemies as well as ours ... We shall fight them together.' For the communists, a coalition of 'all the victims of capitalist exploitation' was the only answer, a coalition which would overthrow the grande bourgeoisie. ${ }^{47}$

Le Temps treated the federation seriously and with some sympathy. 'Whether one likes it or not the spirit of the country has changed ... The good citizen, the excellent taxpayer who used to be content with grumbling, now goes to meetings and participates in demonstrations.' The editorialist concluded that economies were needed in government spending to allow for reductions in taxes. 'Until now tax increases have been more frequent than budget cuts. We hope that ... a new balance will be established. If nothing happens, we will witness the continuation of a situation which will rapidly deteriorate, creating deeper and deeper discontent throughout the land. This is the conclusion that we draw from yesterday's demonstrations. $^{48}$

Members of the government and parliament answered 'National Taxpayers' Day' with a mix of ridicule and threats. Minister of the Budget Lucien Lamoureux brushed off the taxpayer meetings as nothing more than 'artificial agitation,' but hastened to add that a law passed the previous month had made it a crime to organize 'the collective refusal to pay taxes. ${ }^{49}$ Taxpayers beware! Socialist leader LudovicOscar Frossard thought the federation sinister enough to report on it to his colleagues at the Palais Bourbon. He described it as a shabby front organization for big business and its president as a failed businessman, revealing that d'Anthouard was a member of the board of directors of three companies - the Compagnie Française d'Afrique, the Crédit Foncier du Brésil, and the Crédit Commercial et Industriel de Paris - that were part of the scandal-ridden Bouilloux-Lafont group. The first two were in the process of a court-ordered dissolution as the result of mismanagement and the third had suspended its dividend payments. This was the man, stormed Frossard, who dared accuse parliament of corruption and the misuse of public funds! $!^{50}$

Frossard's disclosures may have embarrassed the federation but did not shake its confidence in its leaders. D'Anthouard quickly explained that while Frossard's information was correct, the courts had cleared him of any responsibility in those business misadventures. After all, he was a career diplomat not a businessman and had spent twenty-four years in service outside of France. In short, he was a director in name only and quite a silent partner in matters of management. ${ }^{51}$ Although d'Anthouard's explanation seemed to be accepted, there was still some disagreement among federation members on the tactics which had brought the taxpayers under such scrutiny. A vocal minority opposed the violent demonstrations and the 
inflammatory statements which encouraged breaking the law. ${ }^{52}$ The majority, however, was still armed to do battle. 'The directors of the federation have decided not to back away from any obstacle,' Large announced, 'and to go into the streets if need be, because this is a question of life or death for us all.' He even linked the federation with the notion of some sort of national revolution: 'when the H-Hour is upon us, we will call on you to come in strength to our sides. ${ }^{53}$

Plans for the federation's meetings in Paris on 27 May were watched closely by the police who detected a growing sympathy for the taxpayer spirit among traditionally moderate commercial groups such as the Paris Chamber of Commerce, the Union des Intérêts Économiques, and the Fédération des Groupements Commerciaux et Industriels de France. ${ }^{54}$ Taxpayer propaganda was impressive. Thousands of posters decorated the Paris region and 400,000 handbills were distributed in the city itself by the federation, the Action Française, and the Jeunesses Patriotes. Newspaper publicity, special editions of Le Réveil du contribuable, and favorable press comment forecasted an event of major significance for the taxpayer movement. ${ }^{55}$

Compared with the provincial meetings of 19 March, the Paris rally was disappointing. The 4000 in attendance, divided about evenly between two meeting halls (Magic-City and Salle Bullier), were less than half the number expected by police and much less than that anticipated by the federation. It equaled rather than surpassed previous gatherings in noise and numbers. Federation orators renewed their commitment to a tax strike to bring 'the politicians to their knees,' demanded the establishment of a 'new order,' and, in violation of a pledge made to the police, encouraged the taxpayers to take their protest from the halls into the streets ('vous livrer à des exercises d'action'). ${ }^{56}$ Despite the summons, however, the Camelots du Roi at Bullier had no success at getting the crowd to march on the Chamber, and at Magic-City a small group of Camelots and their followers were quickly dispersed between avenue Bosquet and the Esplanade des Invalides. ${ }^{57}$ Contrary to police intelligence the disappointing turn out and the lack of street action were due to the unwillingness of some of the taxpayer sympathizers - the Comite National d'Entente Économique, the Jeunesses Patriotes, and the Miliciens Socialistes Nationaux - to risk fights with the police. ${ }^{58}$

Nevertheless, Large was arrested while trying to force his way into the house of the budget reporter of the Chamber of Deputies, Paul Jacquier. ${ }^{59}$ And this incident brought forth familiar statements from the leaders of the Republic on a time-honored theme: la République en danger! Radical-Socialist Édouard Herriot spoke of the need 'to defend the republican regime threatened by seditious organizations' and Minister of the Interior Camille Chautemps reminded citizens of the government's duty to ensure 'public order.' At the Palais Bourbon Prime Minister Édouard Daladier promised action against the taxpayers: 'the tumultuous movements, the threats, the violations of the homes of the representatives of the people ... all will be stopped! If the means presently at our disposal are insufficient, I will ask you for more authority. Our troubles will not be solved by street demonstrations. ${ }^{60}$ To all but those who knew him Daladier sounded like a Robespierre-in-the-making ready to defend the Republic at all costs. 
The federation was not cowed. Large wrote to Daladier: 'We have decided - and nothing can stop us - to fight with all our might against any government which works ... against the national interest. We refuse to back down before a dictatorship of incompetents and profiteers.' ${ }^{61}$ This was the tough language of the political leagues! But was his spirited declaration credible given the poor federation performance of 19 May? It was a case of taxpayer talk without taxpayer action. The Comité National d'Entente Économique had quietly disassociated itself with the federation by sponsoring its own meetings, emphasizing that it would pursue its goals in a 'legal and orderly' manner. ${ }^{62}$ The relationship with the veterans' groups had also deteriorated. Veterans' leaders now warned against requesting or accepting any help whatsoever from the taxpayers. ${ }^{63}$ And within the federation there was concern about Large's 'authoritarian and headstrong nature' and about the offhanded way in which he made federation decisions. ${ }^{64}$

The planning session for the federation's 1933 annual meeting was devoted entirely to the 'Large question,' debated in a 'rough and excited' manner. Large stood accused of abusing his authority by organizing demonstrations and issuing press releases without the approval of the governing board and plunging the federation into debt. He was charged with alienating 'the majority of the leaders of the economic groups affiliated with the federation' and bringing the work of the Paris taxpayers' group, the Syndicat des Contribuables Parisiens, to a standstill. ${ }^{65}$ Large's police record may have been growing, but the friends and funds of the federation were not. There were calls for his resignation but the governing board rejected them, proposing instead a compromise whereby a council would assist Large in directing the federation's day-to-day activities. ${ }^{66}$ The anti-Large forces refused to be appeased, however, and renewed their attack on him at the December congress. But Large's supporters who praised his 'combative spirit' and 'devotion' to the taxpayer cause, outnumbered his opponents. The test of strength was the decision to expel the Syndicat des Contribuables Parisiens, whose leaders were among the chief critics of Large's conduct. ${ }^{67}$

Even after Large's victory and the expulsion of some of the dissidents, perfect harmony was never restored; the internal conflicts had taken their toll. Large admitted privately that the federation was in serious financial shape. Many members had failed to renew their memberships and the contributions of some groups were behind schedule. Regretfully he predicted that 'since we cannot count on any significant influx of money before the end of February, it is possible that we will remain dormant until then.' ${ }^{68}$

At the same time the federation was receiving a steady flow of protests from leaders of departmental federations and corporative associations reproaching Large for failing to pursue an aggressive campaign against the government and parliament. ${ }^{69} \mathrm{He}$ was caught in a cross-fire, pressed for action by the provincials, but held back by lack of money and the less-than-wholehearted support in Paris. In fact, while Paris hibernated, the provinces erupted in taxpayer action; 30 meetings were held in winter 1933-1934, all of which centered on the tax strike. ${ }^{70}$ And in December the Ligue des Contribuables de la Gironde organized a protest march together with veterans' groups at Bordeaux which pitted 6000 angry demonstrators against police and firemen. ${ }^{71}$ 


\section{The assassination of Jacques Lemaigre Dubreuil}

At the beginning of January the Action Française appealed 'to the people of Paris' to demonstrate against the government's handling of the Stavisky scandal which implicated national politicians in a municipal bond scandal. There was a special message for taxpayers. 'At a time when the Government and the Parliament of the Republic declare themselves incapable of balancing our budget, and continue to defend the topsy-turvy foundations of their regime; while they refuse to reduce the burden of taxation, and are actually inflicting more taxes on the French people, a scandal breaks out. This scandal shows that, far from protecting the savings of the people, the Republican authorities have given free course to the colossal rackets of an alien crook.' The lengthy brief against government ministers and members of parliament concluded: 'The honest people of France who want to protect their own interests, and who care for the cleanliness of public life, are forced to take the law into their own hands. At the beginning of this week, Parliament will reconvene, and we urge the people of Paris to come in large numbers before the Chamber of Deputies, to cry "Down with the Thieves," and to clamor for honesty and justice. ${ }^{72}$ The appeal was too tempting to let pass and Large agreed to throw in his lot with the Action Française: 'We shall march on this den called the Palais Bourbon and, if necessary, use whips and clubs to clean out this Chamber of Incompetents. ${ }^{73}$ Taxpayers joined the Action Française on the Pont de la Concorde on 23 January and the federation endorsed a second Action Française meeting for 27 January. ${ }^{74}$

Then on 6 February - the day when many thought that the fate of the Republic had hung in the balance - Paris taxpayers marched together with the veterans' groups and political leagues on the Palais Bourbon. This march earned the Taxpayers' Federation a permanent place in the Third Republic's rogues' gallery. Socialist Léon Blum believed that those who had gathered on the Place de la Concorde that Tuesday afternoon had been intent on overthrowing the Republic and establishing an authoritarian regime. The bloody fighting between the police and armed citizens seemed to confirm this. Yet, despite the dead and injured, the demonstrators probably only wanted to serve notice on the Daladier government that many Frenchmen were still dissatisfied with the sad state of public morality.

Not surprisingly, the march did not have the formal approval of the national federation. Rather, it was the Fédération des Contribuables de la Seine, the Paris group created after the expulsion of the Syndicat des Contribuables Parisiens, which called on its members 'according to their political beliefs, personal preferences, or availability of transportation' to join together 'in all the movements which will take place in Paris this Tuesday the sixth. ${ }^{, 75}$ Later in testimony before the parliamentary commission established to investigate the 'events' of 6 February, Large insisted that the national federation 'had not at any moment alerted its members to participate in those demonstrations' and that the Fédération des Contribuables de la Seine had acted 'independently. ${ }^{76}$ Large tried to have it both ways: to participate and not to participate in the march. But there was no doubt of his personal feelings, for he took part in the clashes on the Place de la Concorde. And participate directly or not, the national federation quickly hailed the 'patriotmartyrs' who had been 'assassinated' by the police and exploited the tide of anti- 
government sentiment by asking all taxpayers 'to suspend immediately ... all tax payments, to refuse all credit to the government, and to withdraw all the funds that they kept in public savings institutions. ${ }^{77}$

For many taxpayers Large had committed yet another error in judgment by embroiling the federation in what the Left was calling a coordinated 'fascist' plot to overthrow the Republic and what the extreme Right insisted was a révolution manquée. Overthrowing the Republic was farther than they wanted to go. Moreover, Large further embarrassed the federation by telling the parliamentary commission - in a moment of pique at their rapid-fire questions - that the Taxpayers' Federation did not have and never had had a program of financial reforms. ${ }^{78}$ This was untrue, of course, but it left a bad impression.

To counteract Large's unfavorable performance the taxpayer press reminded its readers of the specific tax and legislative proposals that the federation had made in the past. ${ }^{79}$ And in a letter to Henry Bérenger, president of the Senate Committee for Governmental Reform, Baron d'Anthouard summed up the taxpayers' current agenda: the participation of taxpayer representatives in the oversight of municipal, departmental, and national finances; the reform of the public accounting system to enable the average citizen to understand better the government's financial operations; the creation of a tax court and the recognition of the right of taxpayer groups to defend their members before this body; the official government acknowledgment of the work of the taxpayer groups, granting them the means and necessary authority to carry out their tasks; and the establishment of a supreme court to protect the rights of citizens whenever infringed upon by the public authorities. ${ }^{80}$

Large still praised those who had fallen on the 'field of honor,' but he also talked about peace and order. 'Our duty is to quiet the passions,' he announced, 'to prevent killings and massacres.' In fact, those who wanted 'to fight instead of to reason,' who believed that 'killing one another' was the only way to solve their problems were told 'to enroll in those organizations which have that as their program. ${ }^{81}$ His change of heart had come too late. Citing financial irregularities uncovered during an audit of federation accounts, the central committee of the Taxpayers' Federation asked for his resignation as delegate-general in June 1934. When Large refused, the committee forced the issue and in October voted unanimously to sever all ties with him. Regrettably, this left Large in possession of all the federation assets - the national offices on rue Lafayette, the bank accounts, and Le Réveil du contribuable. ${ }^{82}$

It is tempting to conclude that the events of 6 February 1934 did the Taxpayers' Federation in by casting its middle-class members in the role of hard-bitten enemies of the Republic who used taxpayer protest merely as a means to overturn a despised political regime. And there is no doubt of the sincerity or depth of taxpayer anger. But these taxpayers were really quite reluctant revolutionaries who were genuinely embarrassed by the unhappy consequences of Large's leadership. Still, there was always grudging admiration of the militant 'political' leagues and Peasant Defense. The interim president of the 'new' Taxpayers' Federation - the Fédération Nationale des Contribuables - Dr. Adolphe Javal (who replaced Baron d'Anthouard, now named 'honorary president') was a long-time supporter of 
Dorgères, as was the interim vice-president, Louis Varinot, a successful Paris lawyer, who handled all of Peasant Defense's legal troubles. ${ }^{83}$ Neither of these men was shy of scandal nor wary of skirmishes with politicians in the press or police in the streets. And Dorgères, too, was a member of the federation's executive committee where taxpayer activists (such as Dr. Georges Bardou, the former and controversial president of the Taxpayers' Federation of the Seine, and André Bouton, president of the Taxpayers' Union of the Sarthe, L'Union des Contribuables de la Sarthe) sat in force. ${ }^{84}$ Nevertheless, when the federation sought a new president, it looked to the traditional business community and recruited someone who had had no prior active involvement with the taxpayers nor in fact with any political or public action group of any sort in France.

\section{Jacques Lemaigre Dubreuil and the Taxpayers' Federation}

From March 1935 to September 1939, Jacques Lemaigre Dubreuil, the president, director-general of Georges Lesieur et ses Fils, manufacturers of Huiles Lesieur, the premier vegetable cooking oil in France, presided over the Taxpayers' Federation. In these four-and-a-half years before the Second World War the federation emerged as a pesky critic of the tax and fiscal policies of the governments of the Third Republic and of the economic and financial policies of the political Left in France, particularly those of the Popular Front governments of Socialist Léon Blum. Its notoriety and success were due in large part to the leadership of Lemaigre Dubreuil who sought to apply his considerable managerial skills and the organizational principles of a modern business enterprise to federation operations. In the collective memory of inter-war France the Taxpayers' Federation brought two images to mind - 6 February and Jacques Lemaigre Dubreuil - even though each represented separate and distinct moments in the federation's history.

Lemaigre Dubreuil's pre-Taxpayers' Federation biography is of interest. He was born on 30 October 1894 in Solignac (Haute-Vienne), five miles south of the porcelain center of Limoges, in a region that 100 years earlier Arthur Young, the wandering English agriculturalist, had described as 'by far the most beautiful I have seen in France..${ }^{85}$ Lemaigre Dubreuil never forgot the Limousin of his youth - the green hills and meadows, the open fields, the deep, black, rapid rivers, the distant mountain ridges. Years later he insisted: "I am not myself in this "big Paris" which I do not like because I feel too small here. I am only myself in my dear Limousin where I love the people and the things. ${ }^{86}$ Nevertheless, his parents (and his father was the mayor of Solignac for over 40 years) sent him to Paris for his schooling, first to the École Gerson, a Catholic preparatory school for boys who planned to take the baccalauréat, then to the Institut d'Études Politiques. He was nineteen years old at the outbreak of the Great War in 1914 and he enlisted with the Twentieth Dragoons from Limoges. The following year he was accepted at the cavalry school at Saumur for training with light armored vehicles. In 1916 he was sent to Romania (with the rank of second lieutenant) as part of the French military mission operating with the Romanian army against the Austrians. To reach the 
Romanians, however, the French contingent was first forced to sail north to the Russian port of Murmansk on the Barents Sea, then traverse the entire north-south length of the continent by rail. This trip was repeated in reverse six months later (in June 1917) when the French withdrew their forces. Back in France Lemaigre Dubreuil served with the Ninth Army, winning promotion to first lieutenant on Christmas Day 1918. He was then assigned to the military staff of the French High Commissioner in Constantinople, followed by four years of on-the-ground commands with the Army of the Levant in Syria. Discharged in 1922 with the rank of captain, Lemaigre Dubreuil had spent eight years under the flag, decorated with the Legion of Honor and cited many times for bravery under fire. ${ }^{87}$

Talented, educated, patriotic, and worldly-wise, Lemaigre Dubreuil returned to Paris to a job with the Banque du Pays du Nord, ready to start his peacetime career and in an individual way to help fashion postwar France. Within the year, he joined the firm of Marc Desaché, brokers on the Paris Stock Exchange. Three years later (on 27 January 1926) he married Simone Lesieur, daughter of the founder of Georges Lesieur et ses Fils of Dunkirk; and made his final career move by entering the family business. On the death of Georges Lesieur in 1931 Lemaigre Dubreuil (at the age of 37) became the president and director-general of the company that produced and marketed France's foremost vegetable cooking oil, Huiles Lesieur. In practice he shared the running of the company with Paul Lesieur, the oldest of the Lesieur sons, who chaired the board of directors and oversaw the firm's internal operations at the extensive Dunkirk factory and shipping complex. From his Paris offices Lemaigre Dubreuil concentrated on national and international assignments: the supply of raw materials to Dunkirk from Dakar (principally groundnuts from Senegal from which the peanut oil was extracted and transformed into Lesieur oil) and the marketing of Huiles Lesieur to France and Europe. ${ }^{88}$

The Europe that Lemaigre Dubreuil surveyed from Paris was increasingly preoccupied with the emerging Germany under Hitler. After a short trip across the Rhine in 1934 Lemaigre Dubreuil chanced to read a pamphlet by taxpayer militant Charles Kula who insisted that Hitler's Germany was becoming an armed camp and in consequence that France was in serious military danger. 'In my opinion there is something ... more important for us than just the transformation of the civilian population into soldiers throughout all of Germany,' Lemaigre Dubreuil wrote to Kula. 'It is to witness the total rebirth of their civic spirit (sens moral) as compared with a France which is lost in parliamentary squabbles. A great people is beginning anew under the direction of a leader who knows what he wants and who vigorously applies his principles. ${ }^{89}$

This assessment of the Nazi revolution revealed Lemaigre Dubreuil's own fears of a Third Republic in decline, his frustration with the scandals and corruption of republican politics that had ended in Paris street fighting on 6 February 1934. On that night he, too, was on the Solférino Bridge watching 'with dreadful sadness' as citizens and policemen clashed, and Frenchmen killed Frenchmen. The mix of grievances that brought citizen marchers to the point of assaulting the Palais Bourbon and quickly turning the heart of Paris into a combat zone affected him as well. He regretted the bloodshed and said so, but he did not shrink from the fight. In 
fact, he suggested that it was time to replace talk with action and partisan politics with the interests of France. Was it not proper, he asked, to stand up for all those 'honest people' who in truth had the right not to be 'oppressed' by a 'disgraceful government and parliament' ${ }^{90}$ It was this personal sense of patriotic duty and civic spirit that made him accept the presidency of the Taxpayers' Federation in January 1935. The invitation came in part because of his admiring letter to Kula, newly returned to the federation fold after Large's departure, for apparently it was Kula who first proposed Lemaigre Dubreuil for federation president. Kula later remarked that Lemaigre Dubreuil was the kind of leader that he had 'dreamed of seeing at the head of an army of taxpayers. ${ }^{\text {91 }}$ Dorgères also believed that Lemaigre Dubreuil presented an opportunity for the taxpayers (and perhaps even for Peasant Defense) to recruit a new François Coty, a vigorous entrepreneur with real sympathy for the taxpayer cause and deep pockets as well. Unlike Coty, however, Lemaigre Dubreuil had no desire to play the role of a behind-the-scenes financier or string puller. From the first, he preferred to be on stage, front and center. This was quite a different part for a 'typical' French businessman, for it momentarily pushed his business concerns to the background; and Lesieur was ultimately eclipsed in favor of Lemaigre Dubreuil's public and political involvement with the Taxpayers' Federation.

In March 1935 Lemaigre Dubreuil became the federation president at a Paris meeting that was followed by a reception which also honored two new members of the federation's advisory committee, Marshal Louis Franchet d'Espérey and Joseph Barthélemy, the former dean of the law faculty of the University of Paris. In his acceptance speech Lemaigre Dubreuil promised that he would organize the federation like 'an immense business concern' with an efficient and effective national office, a well-trained staff, and a professional advertising department. He pledged to work for the abolition of 'expensive and useless' government offices and monopolies, the reduction of existing taxes, and the 'judicious use' of taxpayer funds. The first step toward realizing these goals, he insisted, was for parliament to surrender its right to initiate all legislation to increase expenses, a power which he claimed rested solely with the Republic's executive authority. The taxpayers' final goal, of course, was to restore those ideas vital to the nation's health: authority, family, economy, and country. ${ }^{92}$ The press reception was friendly but cautious. After all, who could ever imagine the Chamber of Deputies giving up the right to spend the taxpayers' money, its most potent and lucrative function? Yet following Lemaigre Dubreuil's first public address in April, the moderate Le Journal des débats urged the federation on: 'Tonight marks the beginning of an entirely renovated taxpayer movement. With it go the hopes of many Frenchmen of all classes and categories. To make it strong enough to play a role worthy of these hopes ... it is the duty of everyone to join. ${ }^{93}$

It was clear from the beginning that for Lemaigre Dubreuil the Taxpayers' Federation was only a 'means, not an end in itself.' Although he sought to satisfy the taxpayers' complaints which he believed were legitimate, he emphasized the need to tackle a wide variety of national problems and to use the strength of the taxpayer movement 'to impose a solution on them.' 94 Since the force of the 
movement was critical to the program's progress, Lemaigre Dubreuil appointed a young journalist, Jean Rigault, as federation secretary-general and his second in command, the day-to-day manager of taxpayer affairs, who would spend the bulk of his time on press matters (both with the coordination and development of the taxpayer press and with public relations and publicity in the Paris and provincial press) and on fund-raising as well. ${ }^{95}$ In all this the power of advertising, especially as an instrument of political persuasion and support, was evident. Rigault's press office solicited business and industry contributions to the federation in the form of an agreed-upon percentage of that company's annual advertising budget. Then Rigault himself parceled out this advertising to taxpayer-friendly newspapers. ${ }^{96}$

On the matter of the tax strike the new federation wanted to break with the old federation, but it was not always a clean or easy cut. For example, at Rouen in February 1935 Dorgères warned that if the government refused to heed the farmers' demands, he might be forced to advocate a 'tax strike' and call for the farmers to withdraw all their money from both public and private institutions. André Bouton of the Taxpayers' Union of the Sarthe, Union des Contribuables de la Sarthe and a member of the federation's executive committee wrote to Dorgères that he had reached the same conclusion for the taxpayers. Dorgères's speech and Bouton's letter (which had fallen into the hands of the police) were used as evidence of the complicity of Peasant Defense and the Taxpayers' Federation in illegal action. Both Dorgères and Bouton were arrested. ${ }^{97}$

At first Lemaigre Dubreuil was unwilling to do more than repudiate Bouton and deny that the federation had anything to do with the plans for a tax strike. But when Dorgères was found guilty and sentenced to eight months in prison, he protested the severity of the sentence, hinting that it was intended to prevent Dorgères from becoming a candidate in the spring 1936 legislative elections. In an open letter to Premier Pierre Laval, printed in full in Le Journal des débats and Action française, he asked: 'Can you blame Dorgères for telling his farmers to take every means to protect their homes, their families, and their interests when our institutions are such that to obtain certain indispensable financial measures ... you are forced to ask for decree powers from your own colleagues?' Lemaigre Dubreuil's letter may have had no impact at all, but the Rouen Court of Appeals did reduce, then suspend Dorgères's sentence. ${ }^{98}$

Now a rural celebrity of sorts, Dorgères turned up beside Lemaigre Dubreuil at a combined taxpayer-farmer meeting in Bordeaux (8 July 1935) while airplanes showered the city with handbills. The two teamed up at Beaupréau (Maine-etLoire) two months later at a meeting sponsored by all the agricultural associations of Anjou, and again on 17 September at Larchamp (Mayenne) at a joint rally of the Taxpayers' Federation and Peasant Defense. ${ }^{99}$ Through it all Le Journal des débats praised the farmer-taxpayer cooperation, but warned against 'demagogic agitation' or 'revolutionary methods' such as the refusal to pay taxes. Reason, sweet reason, and, above all, a healthy respect for law and order ought to guide taxpayer action, for, if not, the taxpayers would compromise their own reasonable goals. ${ }^{100}$ All this was not lost on Lemaigre Dubreuil who, speaking for the Taxpayers' Federation under his leadership, insisted: 'We recognize the obligation 
to pay taxes and have never advocated the collective refusal to pay them.' At the same time he commended Dorgères. '[W]ithout Dorgères rural poverty would have driven the farmers to the worst form of international extremism, handing them over to foreign agents.' These were conservative code words for the Red Menace. Some might 'deplore' Dorgères's bluntness, he continued, but it was foolish to think, as the political Left claimed, that the current unrest among the peasantry was due to demagogues and agitators. ${ }^{101}$

Nevertheless, at the height of Dorgères's popularity (and perhaps in part because of it), Lemaigre Dubreuil moved the Taxpayers' Federation away from Peasant Defense, breaking the strategic and financial connections that Dorgères had hoped would grow ever stronger. Despite some advertising from the Taxpayers' Federation in Dorgères's newspapers, the gulf between the farmers and taxpayers widened until Dorgères finally left the federation's executive committee in mid-1936. Then Lemaigre Dubreuil announced the creation of Rural Alliance, Alliance Rurale, the federation's own organizational link to the land, to replace the tie with Peasant Defense. ${ }^{102}$ At a time when politics in France were becoming more polarized, the Taxpayers' Federation chose to be less confrontational or at least less connected to what historian Robert O. Paxton would later call 'peasant fascism.'

In November 1935 Lemaigre Dubreuil's Taxpayers' Federation published a handsome brochure, Les Contribuables, which stated the taxpayer case and proclaimed the taxpayer program. The federation's purpose was to protect 'all those who worked and saved' by organizing them for united action, to suggest remedies for France's economic recovery from the effects of the world-wide economic depression, and to propose comprehensive and far-reaching measures for reshaping the French political, social, and economic system. ${ }^{103}$ To those who wondered why the taxpayers did not concentrate solely on tax matters, Lemaigre Dubreuil answered that there was a connection between 'the general reform of the state and the particular problems affecting the taxpayers.' It was impossible to reform the budget without reforming the state; it was impossible to reform the economy without reforming the state; and to reform the state and the economy without dealing with the social question seemed inconceivable. ${ }^{104}$

According to Les Contribuables, the economic crisis of the 1930s proved the bankruptcy of economic liberalism, a doctrine which in any event never conformed to economic realities. Textbook liberalism proclaimed the unfettered interplay of economic forces and a free, competitive economic system, adjusting itself naturally by the laws of supply and demand. Yet no one was prepared to permit the rules of liberal economics to be the final arbiter of economic success or failure. Businessmen and industrialists banded together for protection or profit, lobbying the government for subsidies or pressing for favorable tariff legislation. At the same time labor unions or workers' parties pushed for economic concessions and social safety nets from both employers and the government. ${ }^{105}$ In the pre-war world and at times of relative national affluence the action of business associations, trade unions, and government on the economy went largely unnoticed. But after the Great War, and especially at a 
moment of economic depression, what had earlier been ignored or accepted with little concern was now an 'insupportable' burden. In particular, the state's demands on the taxpayer had increased at an enormous rate: in 1913 the state requisitioned 24 percent of the national income, 38.8 percent in 1928, 43.5 percent in 1930, 55 percent in 1933, and 65 percent in 1935, the largest part of this in direct and indirect taxes. ${ }^{106}$ And all Frenchmen were not equally affected, leading to a 'social crisis' and the loss of a sense of community because there was simply 'too great a difference in the condition of individuals within the same nation.' Until this social question was resolved, France's future would hang in the balance. The first step in resolving it, however, was to recognize that economic liberalism was unrealistic and outmoded. ${ }^{107}$

Since the government had contributed to the crisis, it was foolish to look to it for help. The increased demands of the state were functions of its increased activity. It had constantly expanded its role in utter disregard of liberal principles which posited a state of limited functions. This was so in large part because the state (and its treasure) were treated as a prize to be divided up among the political parties for their own partisan ends. The result, according to the taxpayers, was a huge public debt and the erosion of all concern with thrift or economy in government. In the end, this would lead to 'the death of the economy' and 'the death of the taxpayer.' ${ }^{108}$ Unfortunately but predictably, the government failed to do anything to improve the disastrous economic situation. At best, politicians tried half-hearted deflationary schemes. At worst they did nothing, hoping that the crisis would pass on its own. Moreover, whenever solutions were proposed, they were always partial and half-hearted measures that avoided the larger and more difficult issues. ${ }^{109}$ Les Contribuables now addressed these issues.

To put an end to the financial legacy of the past, the Taxpayers' Federation first demanded the liquidation of the public and private debt. For the future, they pledged to protect the family, to organize labor, and to reform the administrative structure of the country by reinforcing state authority, setting up professional corporations, and decentralizing the administrative network. ${ }^{110}$

For the family, the taxpayers proposed the family vote, government aid for large families, tax exemptions, and the abolition of legal restrictions on inheritance. ${ }^{111}$ At the heart of the labor question was unemployment, the result of a poorly organized labor market. This was considered one of the pernicious side effects of 'social and economic disorder.' Although the taxpayers endorsed piecemeal solutions such as the restriction of foreign workers, the creation of public works projects, the organization of placement bureaux, raising the minimum working age to fifteen, and the revival of artisan industries, their most important recommendation was the organization of labor into professional corporations. ${ }^{12}$

The Taxpayers' Federation realized that corporatism suggested two extremes: 'paternalism' and 'state socialism.' 'For some, it means a concession by the employers; for others, it means a step toward the abolition of private property.' For the taxpayers corporatism resolved 'the problems of competition, of prices, and of freedom,' permitting a 'free collective economy' to replace a 'directed individual economy.' 'To establish the corporation is to organize the producers 
who are not yet organized, to permit them to benefit from the advantages of the union of professional interests, a union that others have formed giving them the means to influence the market, precisely because their adversaries are not organized. In a word, to establish the corporation is to balance competition by limiting its effects. ${ }^{113}$

Organized at the regional and national levels, the corporation was to be 'an association of producers, grouping together all those who work in the same category of production,' employees as well as employers. The goal was to regulate the interests of the profession and its members. Employers and employees were to be given equal rights, protected by equal representation on all boards of control or decision; disputes would be adjudicated before regional committees with the right of appeal to a regional council and final recourse to a government control board. Corporation membership would be optional for private individuals and small companies, but obligatory for large companies and corporations. ${ }^{114}$

As a social organization, the corporation would concern itself with apprenticeship, job placement, health and life insurance, unemployment compensation, and perhaps one day even the construction and management of housing projects. It would oversee working conditions, establish professional training and educational standards, regulate labor conflicts, design labor contracts, and enforce labor legislation. As an economic institution, it would adapt production to consumption by regulating prices and controlling quality in cooperation with regional, national, and international authorities; and recommend government legislation. As a political institution, it would send delegates (equal in number to those chosen directly by the voters through 'integral' universal suffrage) to regional councils. When these councils met together, they would constitute the Chambre Législative, the national legislative assembly. ${ }^{115}$

Taxpayers hoped that corporatism would put an end to the class struggle and the 'partnership of labor and capital' became one of the important themes of their meetings. Prior to the elections of 1936, which raised class tensions to their highest point in the century, Lemaigre Dubreuil announced: 'To the hatred that presently divides men and political parties, we shall answer that happiness and prosperity can only be found in class collaboration ... To capital confronting labor, we shall counter with labor associating itself with capital, sharing the benefits of the task accomplished in common. We shall demonstrate that the employer and the employee have a social duty to fulfill. ${ }^{116}$ In March 1937 he stated that only with a constructive program stressing 'the cooperation of labor and capital' could one outbid the revolutionaries. 'There is no such thing as salaries or profits by divine right. Workers and owners must have only one goal: the prosperity of the enterprise. You cannot regulate the social question with paid vacations. The only solution, the only way to escape state socialism is the cooperation of labor and capital, I mean the participation of everyone in the profits of the enterprise. ${ }^{117}$ Later, he proposed the idea as a barrier to collectivism and the socialist transformation of society. And in Limoges in 1938 he predicted that class collaboration would bring workers a prosperity far beyond the wildest Marxist dreams. ${ }^{118}$

The taxpayers blamed the imbalance between wholesale and retail prices for the 
economic depression in the countryside and its 'desertion' by farmers and their families. They recommended tax relief, lower interest rates, and the reduction of debts. ${ }^{119}$ To stop rural flight the taxpayers proposed the liquidation of the private debt, a moratorium on taxes, a reduction in certain taxes (in particular, inheritance taxes), the modification of inheritance laws to make the transfer of land easier and to avoid the division of family farms among all the heirs, the regional corporative organization of agriculture (which Dorgères defined as 'the union of members of the profession in a cooperative effort with certain resources in common and under the direction of the best and most competent individuals'), and tariff protection. ${ }^{120}$

The taxpayers' administrative reforms aimed at restoring the state to its proper role, limiting and reinforcing the 'central authority,' and reorganizing regional administration. 'It is necessary to limit the state to its mission and to give it the means to accomplish it. The confusion between decision and supervision, between the executive and the legislative branch is perhaps the most important cause of all our troubles. It is certainly one of the permanent ones. ${ }^{, 21}$ For the taxpayers the state had to be divested of all the functions that did not concern it (for example, state banking, commercial, and insurance operations); these should be returned to private hands. The 'central authority' would consist of executive and legislative branches. The executive would be composed of eight ministries: the prime minister's office, foreign affairs, defense, finance, justice, colonies, public instruction, and national economy. The legislative would comprise a Conseil d'État to prepare legislative texts and decrees at the government's request, to advise on economic and administrative policy, and to act as an arbitration board; and a legislature, the Chambre Législative, which would debate, ratify, or reject the money bills presented by the government, but have no right of initiative in financial matters. $^{122}$

The taxpayers accepted the judgments of the Fédération Régionaliste Française, animated by the well-known geographers Jean Brunhes and Paul Vidal de la Blache, that the départements had created an artificial division between la France économique and la France administrative. To overcome that split they endorsed the establishment of twenty regional assemblies throughout France endowed with economic, judicial, financial, and administrative powers. As the federation saw it, each region would have its own 'spontaneous life.' The state would intervene in the region only as the 'regulator' of French life, the arbiter between different regions, and the guardian of the public order and national safety. ${ }^{123}$

The financial reforms of the Taxpayers' Federation were based on the contention that 'in a modern nation the budget, treasury, currency, and economy are closely linked, but linked precisely in that order ...' Thus, for the taxpayers the budget was of prime importance. 'There can be no social peace without a healthy economy, no healthy economy without a low interest rate, no low interest rate without a strong credit policy, no strong credit policy without a balanced budget.' To achieve a balanced budget, the taxpayers demanded budgetary deflation and proposed a plan that would reduce government spending by over twelve billion francs. ${ }^{124}$

At the same time the taxpayers demanded reductions in taxes which they claimed 'absorb and devour more than half of the country's income.' 'The weight 
of this burden,' they maintained, 'is more insupportable to Frenchmen than the unevenness of its distribution.' ${ }^{125}$ To this end they proposed the outright abolition of the sales tax, the tax on farm profits, and direct inheritance taxes; and they suggested the reduction of the taxes on land, the income surtax, and the tax on income from stocks and bonds. ${ }^{126}$

Taxpayers endorsed a 'diversified' tax system rather than the projects for a single tax whether on expenses or receipts. They believed that the direct taxes compensated for the indirect taxes which taxed low income groups and contributed to the high cost of living. But they did suggest the introduction of a progressive scale in the various scheduler income taxes. They also proposed a new scale for the income surtax, charging that its base was too narrow, its yield uncertain, and its control burdensome; and they suggested methods for its collection and supervision. Finally, they proposed the creation of a taxe de mainmorte mobilière, a 50 percent increase in the tax on stock market transactions and in the stamp tax, and the combination of several small taxes into one. ${ }^{127}$

The taxpayer credo echoed themes that were familiar throughout the 1930s among conservative, middle-class groups unhappy with the leftward march of French democracy and its political and economic consequences. There is no doubt that taxpayer reforms would have compromised the gains made by the working class under the Third Republic's system of universal manhood suffrage, organized political parties, and freely constituted labor unions. To protect the middle class the Republic needed to be reshaped. And this was the point of the taxpayer plan which always identified the national interest with that of the middle class. It is therefore not surprising that, although the Taxpayers' Federation preferred to keep the political leagues (such as the Jeunesses Patriotes and the Action Française) at arms length, it welcomed any association with the veterans' organizations for this underscored its patriotic, national, and militant message.

Lemaigre Dubreuil presided over the Taxpayers' Federation at a time which historian Robert O. Paxton has likened to a period of civil war in France. ${ }^{128}$ The Left - the Radical-Socialist, Socialist, and Communist parties - had combined forces in 1934 to present a common front (called a Popular Front or front populaire) in the 1936 legislative elections against what it termed the 'fascism' of the Right. The Right - moderate to conservative parliamentary groups, political leagues, and national organizations and movements of all sorts - had joined in an organizationally weak yet ideologically strong national front (or front national) to combat what it called the 'communism' of the Left.

Standing with the Right, the Taxpayers' Federation continued to demand the 'abolition of parliamentary initiative on the question of public expenses' and in addition the elimination of 100 seats from the Chamber of Deputies. Both proposals promised to save the taxpayers money, yet neither had any chance of success. Despite petition drives and mass taxpayer meetings in spring 1935 parliament took no notice. Protesting parliament's inaction on a host of reform measures, Lemaigre Dubreuil insisted that he would 'do the impossible to obtain satisfaction through the normal channels,' but he warned that he knew how to take his responsibilities and would not shrink from putting himself at the head of an army of taxpayers 'to 


\section{A LA PORTE LES EXPLOITEURS i}

Pendant que le pays a les yeux tournés vers le Rhin. Pendant que le pays succombe sous les impôts et le chômage. Après deux mois de marchandages et de comédies La Chambre vient de décider

\section{L'AUGMENTATION DU NOMBRE DES DÉPUTÉS}

Toutes les classes de la Nation ont consenti des sacrifices.

Les politiciens ne veulent renoncer à aucun de leurs privilèges.

\section{Voici les noms des exploiteurs de votre région}

qui ont repoussé la diminution du nombre des députés réclamée par tous les Français Les élections sont dans six semaines, quelles que soient vos opinions politiques

\section{IL FAUDRA LES METTRE A LA PORTE}

Seine : Brandon, Piot, Graziani, Montagnon, Perrin, Martineau-Déplat, Jardel, Marsais, Grisoni, Barthélemy, Poncet, Longuet J., Susset.

Seine-et-Marne : Augé, Chaussy.

Seine-et-Oise : Dalimier.

Oise : Jammy-Schmidt, Aubaud, Mellènne, Dupuis, Vassal.

FÉdÉRATION NATIONALE DES CON7 RIBUABLES, 76, Rue de PronY - PARIS

VU: LE CANDIDAT

Plate 1 'A la porte les exploiteurs,' January-February 1936, author's collection.

go down into the streets. ${ }^{129}$ The taxpayers' anti-parliamentary edge became sharper over time. In Les Contribuables, Lemaigre Dubreuil confessed: 'I can see only one solution: to impose these reforms outside of parliament ${ }^{130}$ And by January 1936 he concluded: 'It is through the voice of the country, it is through public opinion that the reforms - which the beneficiaries of the present system refuse to accept - will be imposed. ${ }^{131}$ 
Because of its anti-parliamentary stance, the Taxpayers' Federation never ran candidates for public office. But it did express opinions on both the candidates and the issues. Before the 1936 elections, taxpayer posters condemned past governments of both the Left and the Right, urging voters to support candidates who, once elected, would be willing 'to step aside for the representatives of a regime based on organized trades and professions,' a legal revolution that would empower a new corporate state. ${ }^{132}$ Another poster listed 285 'exploiters' whom voters were told to oust from the current chamber; 240 of those named were Socialists and Radical-Socialists and there was no one on the list from the parties of the Right. ${ }^{133}$ To make taxpayers politics even clearer Lemaigre Dubreuil repeatedly denounced any 'communist or communizing experiment,' insisting that this was opposed to French tradition, freedom, and prosperity. ${ }^{134}$

The victory of the Popular Front, made possible by the discipline of the Left on the second ballot, brought to power a government headed by Léon Blum, the first Socialist to become a premier of France. Blum sought to stimulate the economy by increasing consumption which he hoped would restore normal levels of production. Since the Socialists had no qualms about budget deficits, Blum was prepared to venture into an economic experiment which counted on increased government spending for success. Nevertheless, the Popular Front still pledged a balanced budget, but admitted that it would be the last rather than the first step in the economic recovery plan. ${ }^{135}$

To combat unemployment and the industrial crisis the Popular Front proposed the creation of a National Unemployment Fund, the shortening of the work week without a corresponding reduction in workers' salaries, the establishment of a system of 'adequate' pensions, and the institution of urban and rural public works projects. For the agricultural and commercial crisis the Popular Front suggested higher produce prices combined with a campaign against speculation and the high cost of living in order to reduce the difference between wholesale and retail prices, the creation of a Wheat Office (Office Interprofessionnel des Céréales), aid to agricultural cooperatives, the control of the fertilizer trade, the expansion of agricultural credit, and the reduction of farm rents. To end the financial crisis, the Popular Front recommended transforming the private Bank of France into a public institution; the nationalization of 'war industries;' the 'democratic reform' of the tax system by taxing 'large fortunes' through a 'rapid upward progression' of the income surtax rate on incomes over 75,000 francs, the 'reorganization' of the inheritance tax, and the taxation of the profits of 'defacto' monopolies; and the control of the export of capital. ${ }^{136}$

The Popular Front program was anathema to the Taxpayers' Federation. To draw attention to its complaints the federation scheduled a three-day meeting in Paris, a Taxpayers' Estates-General, the États-Généraux des Contribuables. When the first session opened on 25 June, the country was still feeling the effects of a nation-wide strike of factory workers, begun after the April-May elections and transformed in early June into an occupation of the factories, what labor historians would later call factory 'sit-ins.' These strikes expressed in a dramatic and unexpected way the workers' solidarity with the Popular Front and they immediately 


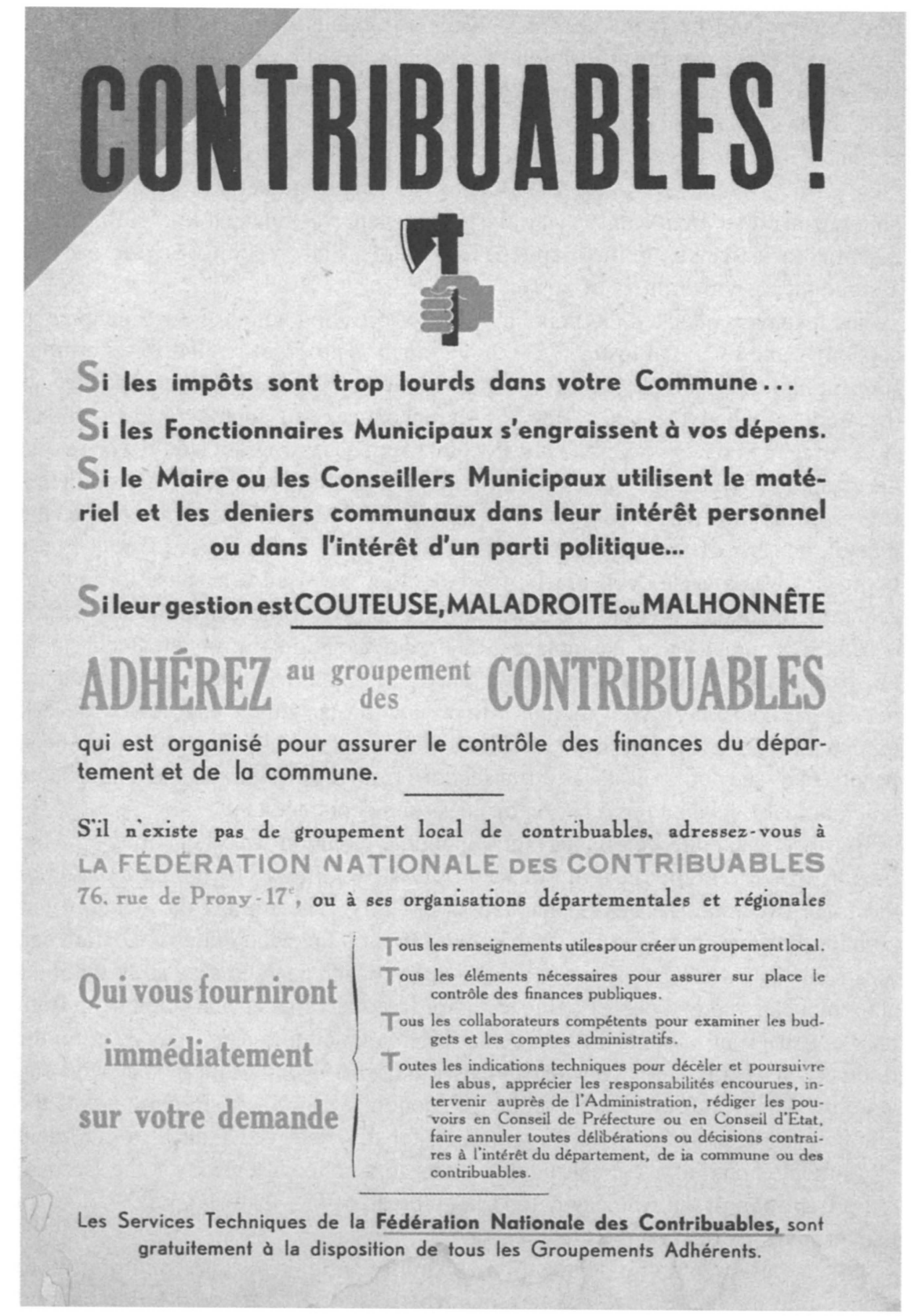

Plate 2 'Contribuables!', 1936, author's collection. 
forced angry and frightened business leaders to make major concessions on the issues of salaries and the arbitration of labor disputes. For the taxpayers it was an example of the fearsome power of organized labor, now working hand-in-hand with the leaders of the government. 'Like the working class,' Lemaigre Dubreuil predicted, 'the taxpayers would have to seek the means to obtain satisfaction for their own just claims.' And referring to the ongoing factory occupations he announced rather menacingly that if the government was 'incapable of fulfilling its essential tasks which are the maintenance of order and freedom, we are ready to assume the responsibilities of power.' ${ }^{137}$

The taxpayers attacked the Popular Front for breaking with 'all the principles of economy' and of 'fiscal justice.' The government's programs called for enormous sums of money which the taxpayers were certain would come from their pockets as the Left reshaped the tax system to fit its concept of 'democratic taxation.' According to Lemaigre Dubreuil, the Popular Front's tax program would work to the disadvantage of the largest category of taxpayers: the middle class. ${ }^{138}$ Although this was probably true, the Popular Front did abolish the 1920 sales tax which topped the federation's list of tax reform recommendations. The Left opposed the sales tax because it was a tax on consumers; the federation opposed it because in times of economic difficulty it could not always be passed on to the consumer and hence became a tax on business. To replace the sales tax the Popular Front created a single tax to be applied at the end of the production process, in theory a tax on the producer, not on the consumer. Even though this production tax might have eased the tax burden on some small merchants and family businesses (which had previously been penalized by the numerous taxable transactions from the producer to the retailer), the federation also labeled this a tax on business and denounced it. ${ }^{139}$

But what catapulted the taxpayers to national attention was their protest of the 'nationalization' of the Bank of France in July 1936 followed by the devaluation of the franc two months later (in September 1936). ${ }^{140}$ The franc's devaluation was perhaps the most controversial of the Popular Front's financial initiatives. Blum had repeatedly stated his opposition to a devaluation which he dismissed as an unthinkable 'monetary coup d'état.' But the economic recovery that he had counted on from the Popular Front's social and economic reforms failed to materialize. In truth, his reform plans, particularly the wage increases and paid vacations for factory workers, were in part responsible for the failure of economic revival. As important was the middle-class fear of the Blum government, for this deprived France of confident investment capital at a critical moment. And international tensions - the German remilitarization of the Rhineland and the outbreak of the Spanish Civil War - also had an adverse effect on the French economy. ${ }^{141}$

The taxpayers saw the devaluation as simply another means of putting more money into the hands of the government (by revalorizing its gold holdings) and not, as the government claimed, an attempt to increase national productivity by making French prices competitive in world markets. ${ }^{142}$ It dramatically amputated middle-class fortunes and the taxpayers decried it as another instrument and consequence of class rule. To forestall devaluation Lemaigre Dubreuil had suggested the less severe practices of borrowing from the Treasury, issuing government 
bonds, and deficit spending. But none of these would have had the economic impact of the currency devaluation. ${ }^{143}$

On the announcement of the devaluation Lemaigre Dubreuil began legal action against Premier Blum and Finance Minister Vincent Auriol on behalf of French taxpayers for 'serious errors and abuse of power ... committed as a result of the recent devaluation of the franc.' He asserted that throughout the summer of 1936 the government had declared devaluation to be an impossibility and that, as a result, this had promoted the sale of the Treasury bonds for $1936 .{ }^{144}$ In fact, only after the bond issue had been fully subscribed did the government move to devalue. On the face of things this seemed a cruel deception. Lemaigre Dubreuil did not stand alone. Paris Municipal Councillors Henri Torchaussé and Gabriel Boissière, organizers of the Committee for the Protection of Holders of Auriol Bonds, followed his lead, citing Blum and Auriol before the twelfth Correctional Chamber. ${ }^{145}$

Within a week of his lawsuit, Lemaigre Dubreuil presented himself as a candidate for the seat of one of the two councillors to be elected by the Bank of France's shareholders. ${ }^{146}$ Meeting in general congress in Paris's Salle Pleyel on 15 October, the shareholders' assembly was a boisterous protest over the government's mismanagement of the nation's finances. Eight hundred stockholders, furious at the currency devaluation, greeted Bank Governor Émile Labeyrie and Councillor Léon Jouhaux, secretary-general of the General Confederation of Labor, with hoots, boos, and cries of 'throw them out!' and 'we've been robbed!' The noise was so loud that a visibly shaken Labeyrie could not make himself heard; and whatever he did say was met with shouts of 'lies, lies!' It was in this atmosphere that Lemaigre Dubreuil was elected a Councillor of the Bank of France, a stunning repudiation of the Popular Front and the most important victory to date for the Taxpayers' Federation. ${ }^{147}$ He summed it up in these words: 'They approved of the fight that I am waging on behalf of economy in government and on behalf of the taxpayers. ${ }^{148}$ And it demonstrated the middle-class fury over the currency devaluation, 'not against the deed itself,' Lemaigre Dubreuil explained, 'but against the circumstances under which it was carried out.' To devalue right after having floated a loan was 'a vulgar swindle.'149

Lemaigre Dubreuil broke the tradition of silence at the Bank of France. He publicized what he discovered about the Bank's operations in a regular column for $L$ 'Action contribuable and not surprisingly he argued that the Bank was the victim of an ongoing 'exploitation' or 'progressive invasion' by the Popular Front government. He predicted that this 'last refuge of the country's credit,' would 'gradually succumb' to the unhappy fate of the nation's finances, if something was not done. The Bank had successfully resisted all assailants from Napoleon Bonaparte to the Communards, but it now risked being 'legally pillaged' without any cry of alarm being raised. 'The patrimony of the Bank is the patrimony of all Frenchmen,' he reminded his readers. 'To save its independence is indispensable.' ${ }^{150}$

In January 1937 he reported that one-fourth of the Bank's active capital was tied up in credit to the government, a figure which he knew would increase substantially 
if one added to it the value of government securities put up as collateral by private interests in their dealings with the Bank. ${ }^{151}$ Because of the state's near monopoly of the Bank's funds (and in consequence of its services), Lemaigre Dubreuil believed that the government was primarily responsible for the increase in the Bank's unproductive resources and operating costs, and the decrease in its productive resources. ${ }^{152}$ Moreover, the Bank had loaned away its independence to the government: the creditor had become the captive of the debtor, quite the reverse of any healthy banking situation. Making matters worse, the state was not a good risk, engaged as it was in a policy of 'disguised inflation.' Finally, there was no end in sight to the improvident and extravagant state's demand for funds. Lemaigre Dubreuil speculated that the legal ceiling on advances to the government had already been exceeded by at least one billion francs, but even this had not met the state's needs. He called for a parliamentary debate on the issues raised by such banking practices and asked the government to make public all the figures on state loans from the Bank. ${ }^{153}$

To transform this deplorable banking situation, Lemaigre Dubreuil insisted on a change in the government's economic and financial policy and in its relations with the Bank. That the Bank ought to remain a separate and independent institution attentive to both public and private concerns became his mantra. 'When the credit of the Bank was separate from that of the state, the former was unassailable. Only when the Bank's activities are reasonably divided between private interests and those of the state, will its resources and its future be assured. ${ }^{\text {,154 }}$

To reclaim the Bank's independence, the Taxpayers' Federation proposed the creation of a banking corporation, an association of all French banks within which the Bank of France would play the central role. The corporation would be free of all government regulation, control, or guarantee, save for the lone civil servant who served as its governor; and the state would immediately withdraw from all competitive banking operations, such as the handling of postal savings accounts. This national banking corporation would permit all French banks to develop in an atmosphere of "coordinated and supervised freedom. ${ }^{155}$ Under this design, inspired by a vision of socialists as unrestrained thieves in a treasure cave of riches, the Bank of France would have greater liberty of action than it had known since 1806 and by virtue of the institutional link with other French banks it would exercise an even greater dominion over the French banking system than it currently did.

Throughout his tenure at the Bank of France Lemaigre Dubreuil complained bitterly about the government's lack of openness and candor. This 'government of revolutionaries in rabbit skins' had promised to make the Bank of France 'a house of glass,' but the stockholders and even the members of the General Council were not consulted or oftentimes informed about crucial issues. ${ }^{156}$ Of major importance to him was the precise nature of the state's transactions with the Bank. He observed that the Popular Front had adopted 'the worst practices of conservative ministers,' then pretended to be 'revolutionary.' 'The situation of the Treasury cannot be hidden forever by playing hide-and-seek with the Bank of France. ${ }^{157} \mathrm{He}$ specifically objected to including all of the gold 'mortgaged' in loans to Great Britain in the tally of the Bank's assets. 'It is of utmost importance 
to distinguish between the gold reserves of the Bank that remain its property and the gold which has been already pledged.' ${ }^{158}$

The Bank's 'democratization' had reduced the control of the shareholders and isolated them from the Bank's affairs. Although the stockholder representatives on the General Council were elected to inform and protect the shareholders, this was hard to do. The councillors, like the stockholders, were informed of the Bank's operations "through the newspapers. ${ }^{159}$ In consequence, 'in the democratized bank the stockholders had to defend their interests themselves and to do this they needed to rely on public opinion. ${ }^{, 160}$ Here the interests of the stockholders and the Taxpayers' Federation coincided, for the federation always favored the reduction of state authority at the Bank and the restoration of shareholder authority by replacing some of the government's representatives on the Council with stockholder representatives. ${ }^{161}$ And from the first the federation believed that public opinion was its strong right arm: after Lemaigre Dubreuil's election to the Bank Council, the federation set up a Bank of France committee and L'Action contribuable ran his regular column on the Bank of France.

The annual Bank of France stockholders' meeting in January 1937 repeated the performance of the October 1936 meeting. Disorderly conduct ruled the day with boos and shouts of 'resign! resign!' directed at Governor Labeyrie; Le Jour called it a 'carnival atmosphere.' On the other hand, there was loud applause every time Lemaigre Dubreuil spoke, so Le Canard enchainé dubbed it 'Lemaigre Dubreuil's General Assembly. ${ }^{162}$ The stockholders also showed their continuing displeasure with the government and its relationship with the Bank by adopting a resolution requesting the government to pay off its debts to the Bank. ${ }^{163}$

The Spanish Civil War presented the Popular Front with one of its toughest diplomatic problems, forcing it to navigate between an ideological sympathy for the Spanish republicans and their cause and the need to maintain a strict neutrality between the warring sides. This was hard to do. At the outset of the conflict the republican government in Madrid sent a shipment of gold bullion from the Bank of Spain to the Bank of France as collateral for a loan destined to purchase needed military equipment. Although all this was handled in complete secrecy, Lemaigre Dubreuil pieced together what he knew of the dealings for his articles in L'Action contribuable, Le Jour, and Le Journal. He revealed that the General Council had not been informed of the negotiations between the two state banks and admitted that it was impossible to know for sure if the Spanish gold was in French vaults. But he guessed that the bullion was indeed on deposit in Paris, concealed in the Exchange Stabilization Fund, an account closed to everyone but the governor. Moreover, he reported that 'everything seems to indicate ... that the Bank of France has transferred almost the totality of the sums which have been deposited with it by means of French bank notes to the Banque Commerciale de l'Europe du Nord in Paris and to the Peoples' Bank of Moscow Ltd. which are the representatives of the U.S.S.R. in France and England.' Given the fact that the export of gold seemed to violate Spanish currency regulations, he asked whether it was wise for the Bank of France to be involved in this transaction. And what would happen if a victorious nationalist government refused to recognize the obligations undertaken 
by the republic and insisted on the return of the gold? ?64 $^{16}$

Although he only discussed the financial side of the Spanish gold matter in his articles, Lemaigre Dubreuil embarrassed the Popular Front government by showing its quiet and significant financial intervention on the side of the Spanish republic despite its public statements of political neutrality. This was ammunition for antiLeftists of all sorts who opposed any aid to the Spanish Republic on political grounds, and especially financial aid in helping it to secure the materials of war. At the same time the fact that the General Council was ignorant of the precise nature of the Bank of France's commitments to the Bank of Spain pointed up the hypocrisy of the so-called 'glass window' in the Bank of France. ${ }^{165}$ Eight months went by before the Bank's governor acknowledged the presence of the Spanish gold in Paris and confirmed the transactions about which Lemaigre Dubreuil had speculated.

In 1938 the Bank of Spain repaid the loan from the Bank of France (in much devalued French francs, noted Lemaigre Dubreuil) and the Spanish governor requested the return of the gold bullion. ${ }^{166}$ Lemaigre Dubreuil advised against the gold's return until the end of the civil war because of the political split that had developed within the Bank of Spain. The Bank's governor was a republican appointee, but the directors were supporters of the nationalist cause. The governor wanted the gold returned to the Republic, yet the directors wanted it to remain in Paris until the end of the war (and the hoped-for nationalist victory). On this issue Bank of France Governor Pierre Fournier (who had replaced Labeyrie in 1937) sided with Lemaigre Dubreuil. While acknowledging that the republican government was the legal government of Spain, he thought it imprudent to become involved in the internal politics of the Bank of Spain. Therefore, the gold remained in French vaults until the end of the civil war when it was returned, as the directors had wished, to the nationalist government of General Francisco Franco. ${ }^{167}$

In February 1937 the Blum government announced a 'pause' in the Popular Front's economic and social reforms. The first change was a renewed commitment to a balanced budget, then the re-establishment of a free market in gold transactions, and finally the appointment of a team of conservative experts to the Exchange Stabilization Fund. ${ }^{168}$ It all signaled a slide toward financial orthodoxy. Lemaigre Dubreuil underscored: 'the important thing is that Monsieur Blum is renouncing his policy of compulsion,' but, more than that, the new policy was 'the exact opposite of everything that has been done since June $1936 .{ }^{169} \mathrm{He}$ could see no reason why the Bank of France, which had caved in to every government request for the previous six months, would refuse to follow the government when it returned to the traditional policy of the directors. Yet if the new policy turned clearly toward classical liberalism, Lemaigre Dubreuil imagined it would pose a real dilemma for Governor Labeyrie who had championed quite a different course. ${ }^{170}$

Blum resigned from the premiership in June when the Senate rejected his request for emergency financial decree powers, ending the first and most daring Popular Front ministry. Radical-Socialist Camille Chautemps succeeded Blum, promising to continue the Popular Front's policies, yet he named Georges Bonnet as his minister of finance; Bonnet had opposed the 1936 currency devaluation and ridiculed Blum's purchasing power theory and, therefore, was 'anathema' to the 

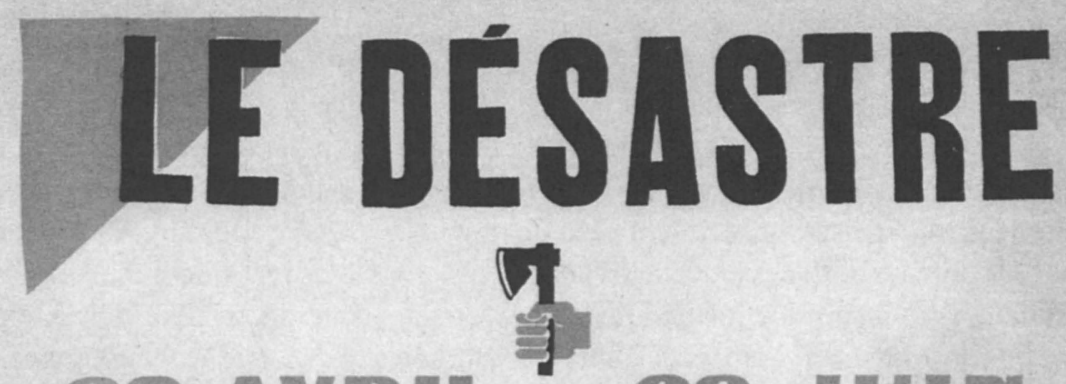

\section{9}
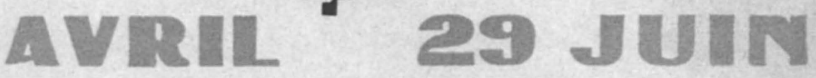

Le déficit du budget ordinaire restant ò couvrir ne devrait pas excéder 1.400 millions. II sera attènué, i'en suis persuadé....

Les besoins de l'Etat seront aisement couverts.

Le fonds d'égalisation a reconstitue ses ressources en devises. .il a toutes les reserves necessaires.

La loi monétaire a limité les oscillations possibles du franc. Nous ne deposserons pas ces limites.

VINCENT AURIOL

- la Commission des Finances de la Chambre 29/4/37.

Le déficit budgétaire peut être évalué à 7 ou 8 milliards.

D'ici la fin de l'année, le trésor devra faire face à 27 milliards de dépenses. Le compte du trésor à la Banque de France $n^{\prime}$ est que de 20 millions La trésorerie est vide.

Le fonds de stabilisation a complètement épuisé sa provision d’or.

Nous ne pouvons plus rester enserrés dans les limites fixées par la loi monètaire.

\section{GEORGES BONNET a la Chambre des Députes 29/6/37}

Monsieur Vincent AURIOL est Ministre de la Juslice S'il y avait une justice en France, Monsieur Vincent AURIOL serait aujourd hui traduit devant la Haute Cour

3. Lemaigre dubreuil Action contribuable du $2 / 7 / 37$

FEderATION MATIOMALE DES CONTRIBUABLES 76 RUE DE PRONY - PARIS 17!

Plate 3 'Le désastre,' July-August 1937, author's collection.

socialists. ${ }^{171}$ In July Pierre Fournier replaced Labeyrie as governor of the Bank of France. Lemaigre Dubreuil welcomed him as 'a great and eminent civil servant, ' $a$ man of authority and of perfect courtesy who combines expert financial knowledge with a remarkable gift of clear exposition. ${ }^{172}$ And in time the conservative press hailed Fournier as 'an objective and lucid technician' whose credo was 


\section{The assassination of Jacques Lemaigre Dubreuil}

'work, economy, balance.' ${ }^{173}$ These appointments signaled the return to a much more conservative economic policy.

Nevertheless, Lemaigre Dubreuil challenged the optimistic assumption that Blum's replacement by Chautemps and Bonnet or the 'pause' policy had really changed anything. As far as he could tell, the country was still being impoverished, transformed, and 'proletarianized.' National finances remained in disorder. He granted that the treasury deficit had been dealt with in part by adopting a 'floating franc' - a defacto currency devaluation - but two problems remained: the need to accelerate national production and to achieve a balanced budget. Neither problem could be solved, so said Lemaigre Dubreuil, without abandoning the 40 hour week which had become part of the mystique of the Popular Front. ${ }^{174}$

When Bonnet did present a balanced budget for the approval of the finance commission of the Chamber of Deputies, Lemaigre Dubreuil wondered whether the balance was 'real' or just on paper. The projected increase in receipts implied 'an overwhelming resumption of economic activity.' And Bonnet's estimates for administrative expenses in 1938 were identical to those of 1937 which meant that Bonnet believed the increase of wages and worker benefits would have no effect on costs. If indeed a stability in administrative expenses could result from the 'rationalization and normalization' of administrative services, it would be excellent news for hard-pressed businessmen who might well conclude that through organization one could reduce retail prices yet at the same time increase both salaries and production. Lemaigre Dubreuil remained skeptical: the Bonnet budget was based on 'hope' - the hope of economic revival and the success of administrative reform. ${ }^{175}$ 'It was exploiting the confidence of Frenchmen ... to proclaim a balanced budget when one really does not exist. ${ }^{, 176}$

Bonnet's determination to defend his budget against all comers won him Lemaigre Dubreuil's praise. He conceded that Bonnet's budget, unlike those of the recent past, tended toward balance and that that was something worth fighting for. 'But each of us knows that an absolute balance cannot be predicted with a floating franc, and that any budget whose receipts are based on a 30 to 40 percent increase in tax revenues without a corresponding increase in expenses despite a rise in prices can only post a deficit at year's end.' Still, he congratulated Bonnet for assuming 'the difficult task of correcting the errors of the past' and expressed his own hope that this economic program would bring about a 'monetary pause' which would then enable the government to undertake needed 'structural reforms. "177

The Bank's new direction affected the stockholders' attitudes at once. The calm, orderly annual meetings of 1938 and 1939 contrasted with the boisterous sessions of 1936 and 1937. And when Paul Reynaud was appointed minister of finance in 1938, the shift to orthodox financial experts was complete. Reynaud immediately concluded an agreement with the Bank to repay the government's debt and to increase the amount which the state paid for the Bank's services, matters which Lemaigre Dubreuil had championed and decisions which he greeted with 'enthusiasm.' ${ }^{178}$ Despite his genuine pleasure at the turn of events and a sense of accomplishment at the Bank, Lemaigre Dubreuil remained convinced that the Popular Front's legacy would be difficult to overcome because the Bank continued to be the 'prisoner of the state.' ${ }^{179}$ 
In January 1939 Lemaigre Dubreuil's term of office expired and since the law forbade councillors to succeed themselves, he chose to run for the post of adviser. 'For three years,' he summed up, 'my work as a councillor has been troublesome for a number of private interests. If I am elected an adviser, I will not change my conduct in any way. Need I add that if I am called upon to choose between the public welfare and the welfare of the stockholders that I will choose the public welfare? ${ }^{180}$ After Georges Baugnies decided not to run for re-election, the field was clear and Lemaigre Dubreuil was elected an adviser of the Bank of France at the annual meeting on 27 January 1939. He pledged to work for the creation of a 'powerful, entirely independent' stockholders' association which would oversee the administration of the Bank, consult with the stockholders' representatives on the General Council, and block the 'invasions of the state. ${ }^{181}$ In essence this was the taxpayer formula for the control of public finances applied to the Bank of France.

The notoriety that Lemaigre Dubreuil gained at the Bank of France boosted the efforts of the Taxpayers' Federation to reform municipal finances which was the federation's principal initiative between 1937 and the coming of war in 1939. Real reform required the establishment of budgetary control commissions under the auspices of the Taxpayers' Federation. 'We want the municipal budget to be overseen by the taxpayers of each municipality, that of the departement by the departmental group, and that of the national government by the national organization., 182 To show what the taxpayers meant in summer 1937 the federation turned to the budget of the city of Paris.

The 1938 budget proposal of the Prefect of the Seine, Paris's chief executive officer, called for increased city taxes as part of a financial plan to liquidate the city's 800 million franc deficit carried over from the previous year. Chairman of the City Council Budget Committee François Latour, called the plan a 'façade.' The deficit was to be covered by a special one-time contribution from the national government (187 million francs), a temporary advance from the national government (137 million francs), and by loans ( 500 million francs). Latour countered with a suggestion of 'massive economies' and a total financial restructuring. But he added that the council was faced with the unhappy prospect of either voting the budget or being dissolved by the prefect (and the prefect's appointment of a governing commission until the next regularly scheduled municipal elections). ${ }^{183}$

The Taxpayers' Federation agreed with Latour's criticism of the budget and was particularly outraged at the prefect's plan for more taxes. According to the federation, such a sacrifice was 'intolerable' because the taxpayers simply lacked the capacity to pay, because the taxes would raise the cost of living, and because it was unfair to make 'one category of citizens' - the middle class - pay for the consequences of 'a policy of excess and waste.' ${ }^{184}$

When the city council actually began considering the new budget proposal in November, the federation moved into action. The federation's supervisory committee, created 'to examine the total amount as well as the purpose of the taxes levied for the benefit of the city of Paris,' told the president of the city council that it would begin to scrutinize the city's budget reports and that its members would attend the public sessions of the council whenever budget 
matters were discussed. It asked that federation members be allowed to follow the work of 'various committees' at city hall - finances, public works, health and that they be accredited to certain city departments. ${ }^{185}$ The request remained without response until an even sterner demand was delivered in person to the council president who agreed to provide the taxpayers with council documents but refused to admit the federation delegates to the closed sessions of the committees in question. 'The powers-that-be in our public administration,' explained L'Action contribuable, 'both underestimate and fear the ability of a taxpayer organization to exercise an effective control over public finances. They are waiting for the taxpayer supervisory committee to prove its technical and administrative competence without really believing that it is possible. ${ }^{186}$ At the same time, however, the federation decided to show its muscle.

The federation announced a meeting of Paris taxpayers at the Salle Wagram on 15 December 'to show its firm intention of organizing a thoroughgoing oversight of the finances of the city of Paris. ${ }^{187}$ And the federation's posters - which detailed the prefect's proposed increases in the business, rent, and real estate taxes and pointed out the near-doubling of water, gas, and transportation costs in the last eight months - urged the city councillors not to vote for the budget. 'To vote such a budget,' the federation insisted, 'is to ruin merchants, renters, and owners. It is to assassinate the taxpayers!' ${ }^{188}$

At the city council, budget reporter André Puech read the federation poster aloud, then excerpts from Lemaigre Dubreuil's article on Paris finances which had appeared in Le Journal that very morning. He was annoyed by the poster, but found the newspaper account 'wiser' and 'more judicious,' yet filled with contradictions. Nevertheless, the federation's advice fell on deaf ears: the city council still voted the budget by the wide margin of 44 to $25 .{ }^{189}$

Convinced that the council had voted the budget for fear of being dismissed and not out of conviction, Lemaigre Dubreuil insisted that as long as city councils were subject to political pressures no improvement in the condition of local finances was possible. ${ }^{190}$ 'The true politics, the only politics, especially in the Paris City Council, is the sound administration of the public patrimony. Whether men are of the Left or of the Right makes no difference. What is necessary is that they be honest, disinterested, and competent administrators. This is the great reform that must be envisaged for a great many French administrations and not so much in the administration itself as in the public leaders who influence it., ${ }^{191}$

While printing Lemaigre Dubreuil's letter on the city council, Henri de Kérillis, political editor of the conservative L'Époque, called his 'great reform' hopelessly naive. It was impossible to govern Paris without playing politics. Had the city council refused to vote the budget, the minister of the interior would gladly have replaced it with a 'communo-socialistic team,' making things even worse for Paris taxpayers. Lemaigre Dubreuil's reform 'might be fashionable in a totalitarian regime,' concluded de Kérillis, 'but we live in a democratic one!' 192 The nationalist Gringoire echoed de Kérillis, predicting that had not the prefect's budget been passed, a Popular Front commission would have taken over city hall until the elections of May $1941 .^{193}$ 


\section{Contribluable sol

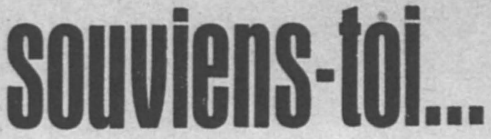

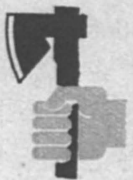

Sur l'insistance du Préfet de la Seine

41 Conseillers Municipaux ont voté

un Budget qui achève le Contribuable.

\section{VOICI LEURS NOMS :}

\section{CONTRIBUABLE SOUVIENS-TOI}

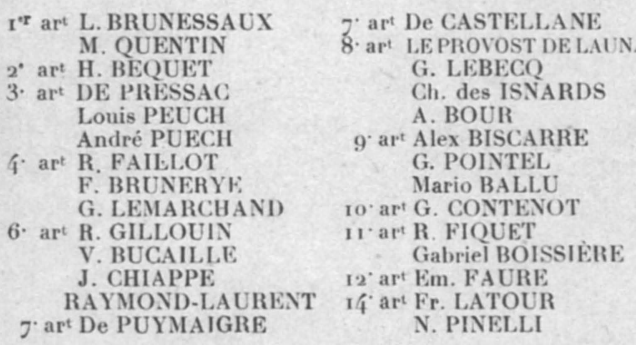

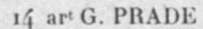

I5 art R. RIGAUD

Lionel NASTORG

A. BOULARD

I6. art G. GAILLARD

De FONTENAY

$17^{\prime} \operatorname{art}^{t} \mathrm{~A}$. MASSARD

L. FOURES

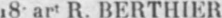

H. TORCHAUSSE

SABATIER

V. CONSTANT

I9. art FIANCETTE

Jusqu'où ira désormais la lâcheté de la majorité du Conseil Municipal sous le chantage de la dissolution ?

Une majorité Nationale qui manque de courage civique, est une majorité qui vá au suicide.

La couleur des Conseillers Municipaux importe d'ailleurs peu aux Contribuables,

\section{CE QU'ILS VEULENT A L'HOTEL DE VILLE} ce sont des. Administrateurs,

\section{et non des Politiciens.}

Pour le Groupement des Contribuables, Producteurs el Commercunts de Paris-Bantieue LE PRESIDENT.

LES VICE-PRESIDENTS,

LES VINGT PRESIDENTS D'ARRONDISSEMENT

Fédération Nationale des Contribuables, $7^{6}$, rue de Prony, PARIS ( $1 \gamma^{\circ}$ - GAL. jo-11

Plate 4 'Contribuable souviens-toi ...,' February 1938, author's collection. 
The federation refused to give up. It invited the 41 conservative councillors (of the 44 municipal councillors who had voted the budget) to explain their vote to a taxpayer rally at Salle Wagram. Since not one of the Paris councillors showed up, 41 chairs on the speaker's platform remained empty throughout the 9 February meeting, mute testimony to an unresponsive group of elected officials. Three months later at the Salle de la Mutualité the federation insisted again on the importance of a policy of 'vigorous budgetary deflation' to restore stability to Paris finances and once more accused the city councillors of lacking the courage to protest tax increases. To underscore the seriousness of the situation, Lemaigre Dubreuil told Paris taxpayers to pay only that portion of their 1938 taxes that equaled what they had paid in 1936. As for the unpaid balance, Parisians should withhold its payment until they were convinced that their tax money was being well spent. 'We are willing to contribute to all necessary expenditures,' granted Lemaigre Dubreuil. 'But not to the costs of demagoguery.' In addition, he asked each taxpayer to send one of his unpaid tax bills to the president of the taxpayers' organization of his arrondissement or quartier so that packets of these unpaid bills could be ceremoniously presented to the respective city councillors. The era of 'useless hand wringing' was over, warned Lemaigre Dubreuil, and the period of taxpayer 'deeds' had begun. This was the 'first step,' he acknowledged, on the path toward an 'effective tax strike,' if those responsible for municipal or national administration forced the taxpayers down that road. ${ }^{194}$ And it was the first time since 6 February that the words 'tax strike' had been spoken with serious intent.

Despite Lemaigre Dubreuil's threats, the Paris city council was unwilling to reverse itself, even though in June 1938 seven council members who had voted for the budget did suggest a moratorium on taxes. ${ }^{195}$ And in July budget reporter Puech revealed that the city's budget deficit had climbed to almost one billion francs, cold comfort for the federation which recalled that it had predicted this dire financial situation. ${ }^{196}$

To prepare for the debate on the 1939 city budget the Taxpayers' Federation published a detailed study of Paris finances, La Gestion de la ville de Paris: le projet du budget contribuable, a taxpayer budget counterproposal. ${ }^{197}$ In it Lemaigre Dubreuil asserted that 1.5 million francs could be cut from the prefect's budget by reducing 'abnormal' expenses for city personnel, public assistance, and the Paris Metro. Admittedly regrettable, these reductions would not affect 'normal' city operations. They would, however, permit the city to balance its budget by matching expenses with receipts - the only tried and true method, 'old as the world and the only correct one' and allow for some selective tax reductions. ${ }^{198}$ And to present the taxpayers' case at city hall Lemaigre Dubreuil announced the formation of an Inter-professional Coordinating Committee of Paris Taxpayers, the union of the Taxpayers' Federation and fifteen professional groups. The committee met with City Council President Gaston Le Provost de Launay for the first time on Christmas Eve, 1938, then for a second time (with Lemaigre Dubreuil at its head) on 29 December. ${ }^{199}$

On the floor of city hall budget reporter André Puech, who had himself already suggested 'a massive reduction of expenses' in the current budget, responded to the 


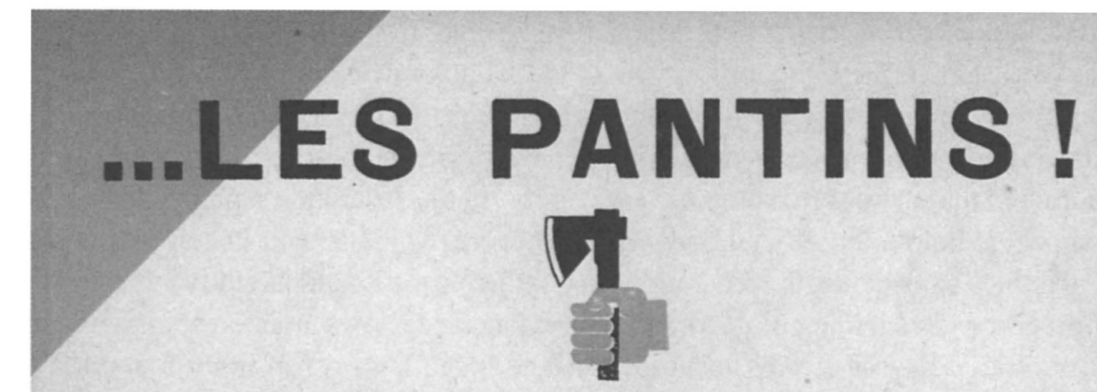

Maintenant que les feuilles d'impôts arrivent les CONSEILLERS MUNICIPAUX SE DÉFILENT

Les COMMUNISTES accusent la majorité d'avoir voté un budget qu'ils ont contribué à gonfler plus que personne.

Les MODÉRÉS accusent le Front Populaire de la hausse verticale des impôts.

D'accord ! Mais la gabegie dure depuis dix ans.

Ils sont tous à mettre dans le même panier

\section{Aujourd'hui 7 Conseillers de la majorité}

MM. BALLU, BISCARRE, BOISSIERE, BRUNERYE, POINTEL PRADE, TORCHAUSSE

demandent un MORATOIRE pour les impôts écrasants qu'ils ont votés il y a 4 mois.

\section{Tas de Farceurs !}

Si le moratoire est nécessaire, c'est que les impôts sont trop lourds.

S'ils sont trop lourds, pourquoi les avez-vous votés ?

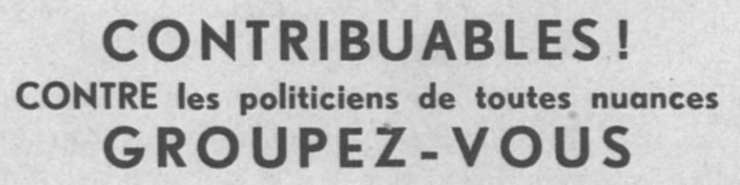

Adhérez au Groupement des Contribuables de Paris-Banlieue LE COMITE DIRECTEUR

FEDERATION NATIONALE DES CONTRIBUABLES 76 , rue de Prony, PARIS $(1 ;)^{\circ}$ - GALVANI $70-11$

Plate 5 'Les Pantins,' June 1938, author's collection. 
Taxpayers' Federation. It was not 'reasonably possible' to slice one-fifth of the budget at the very start of the budget discussions, but he acknowledged that the federation proposal was 'more judicious' than some might think. That was because the cuts that the federation asked for were slated to happen over time rather than in one year alone. He admitted that there were some 'serious errors' in the federation's proposal since it had appeared before the official budget figures were available. But Puech concluded that, all things considered, the federation was 'rather prudent' and its study indicated 'a very precise understanding of the problems we face and shows an interest in financial renovation to which it is only fair to pay tribute.' Still, in a confusing turnabout, he rejected the federation proposal on the grounds that 'such massive cuts at the present time would bring the city administration to a standstill. ${ }^{200}$

On the other hand, André Boulard, who had been criticized by the Taxpayers' Federation for supporting the previous year's budget, volunteered to sponsor the federation's proposal as a budget counter-project. He admitted that his own ignorance of the technical data prevented him from knowing whether the federation's statistics were correct or not, but he was impressed with the thoughtfulness and thoroughness of the federation study. 'Either the cuts proposed by the Taxpayers' Federation are accurate, real, and in fact admissible - and there is no reason why we should not apply them - or else they are impossible ... and we shall ask the budget reporter and the administration to tell us why ....201

Despite some headway at city hall, Lemaigre Dubreuil encouraged resistance to the taxpayer proposals by making undiplomatic statements in the press. He ridiculed the prefect's proposal and said that if it were not defeated by the council, he would publish 'a monstrous dossier of frauds' that had occurred under the councillors' noses. ${ }^{202}$ Puech and Socialist Louis Castellaz were both annoyed at the federation's 'insolent orders. ${ }^{.203}$ And René Gillouin was convinced that the budget debate was being conducted 'in an unjustified atmosphere of nervousness and pessimism,' unless one imagined that the specter of Lemaigre Dubreuil hovering over the next city election was a sufficient justification. ${ }^{204}$

The Left in the city council was angry because it believed that the federation had won some converts. To Communist Gaston Auguet, Lemaigre Dubreuil was an exponent of 'fascist and reactionary' politics: 'In truth, this so-called taxpayers' group naturally refrains from asking the necessary sacrifices from those classes favored with success.' En bloc the communists at city hall rejected both the prefect's and the Taxpayers' Federation's proposals in favor of their own which called for 'a private contribution from the rich people of Paris. ${ }^{205}$ The Workers' Unity Party, Parti d'Unité Prolétarienne, dissident communists since 1929, accused Lemaigre Dubreuil and the Taxpayers' Federation of being lost in a fairytale world of simple solutions. And Socialist Georges Hirsch said about the same thing: 'With what joy we would rally to these projects, if they were reasonable! With what eagerness we would repeat the reproaches they contain, if they were justified! But for the most part these seem improvisations which will be reiterated by other leagues, since they are demagogic., ${ }^{206}$

When finally brought to a vote, the budget passed 48 votes to 36 . Selfappointed sponsor of the federation proposal André Boulard abstained because 
he insisted that the federation proposal was never given a fair hearing in the full council. It had been sent to the budget committee 'where it was buried,' the prefect and the city administration carefully ignoring it. On the other hand, although Castellaz and the socialist group voted against the budget, they said it was because it was inspired by the Taxpayers' Federation. The communists voted against the budget as well, but without comment. ${ }^{207}$

Nevertheless, the city council did reduce expenditures and the Taxpayers' Federation took a share of the credit. The Inter-professional Committee of Taxpayers announced:

The budget of the city of Paris which was voted yesterday provides for a loan of 310 million francs. It must be recalled that the budget proposals at the beginning of December envisioned a deficit of nearly 800 million francs, half to be covered by taxes, half by loans. Thus, 500 million francs have been saved. You can understand the importance of this sum if you realize that 500 million francs represents 50 percent of the property taxes ... This is an example of what could happen ... if the taxpayers united against the pillagers of the budget. ${ }^{208}$

Le Journal des débats insisted that this was the first time in six years that the deficit had been reduced by 'sizeable proportions' and that it was the very first time that the taxpayers who had to submit to the tax burden had organized 'an effective control' over the budget process. It was unfortunate that things had to be done this way, but it would be deplorable if 'abuses' remained uncorrected and bankruptcy continued to be the 'normal condition' of city government. ${ }^{209}$ Lemaigre Dubreuil made no apologies for the taxpayer action, calling this task a true civic obligation: 'in a democracy the citizen has a role to play in the daily life of the state. Freedom is not the freedom to receive, it is the freedom to act. To participate day-by-day, hour-by-hour in the life of the nation is the proper role of a great people. ${ }^{210}$

The most rousing and significant taxpayer interventions in municipal affairs occurred in Saint-Étienne in May 1938 and in Toulouse two months later. Both episodes involved member groups of the Taxpayers' Federation in citizen protests against an increase in local taxes as well as the 8 percent increase in national taxes announced by Premier Édouard Daladier in early May.

In Saint-Étienne most shops closed on the afternoon of 24 May. Storekeepers' window signs read: 'This establishment will be closed Tuesday 24 May 1938 from 2 to $6 \mathrm{pm}$ to protest the unusual increase in municipal and departmental taxes' and 'To stop the increase in the cost of living, we protest the unusual and unjustified increase in municipal and departmental taxes. We can pay no longer ... Consumers, help us!' During the shutdown the storekeepers marched through the streets of Saint-Étienne to the Palais des Sports where a crowd estimated at 20,000 cheered speeches listing the taxpayer grievances and endorsed a resolution to be presented to the public authorities. They denounced the $60-90$ percent increase in local taxes and demanded a reduction of 10 percent in departmental taxes and 20 percent in municipal taxes with payment delays of at least eighteen months. They 


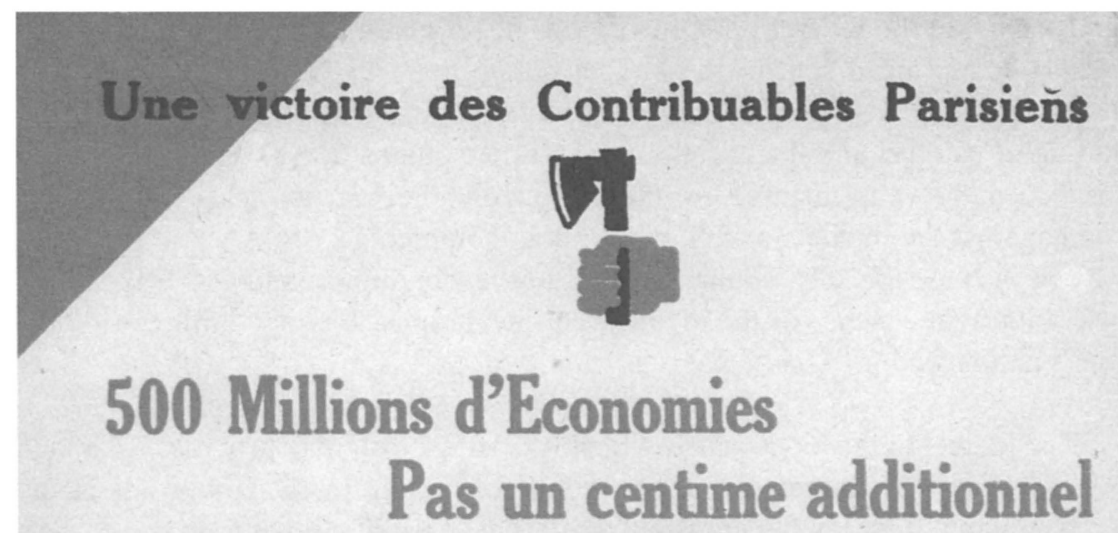

Le Préfet de la Seine annonçait un DEFICIT de 900 millions

Il proposaie : $\mid \begin{aligned} & 500 \text { millions d'emprunts } \\ & 400 \text { millions d'impôts et de taxes }\end{aligned}$

Grâce au rapport établi par la Commission de Contrôle de la Fédération Nationale des Contribuables. (1)

Grâce à la collaboration des principaux groupements professionnels de la région parisienne qui ont adopté les conclusions de ce rapport.

MALGRÉ L'OPPOSITION DE L'ADMINISTRATION

500 Millions d'économies sont opérées

Le déficit a été réduit a 300 Millions couverts par lemprunt SANS AUCUN CENTIME ADDITIONNEL

Dans tout le pays le contrôle est en marche.

A Nantes, a Saint-Btienne. à Toulouse, à Tourcoing. etc., les associations de contribuables font échec à laugmentation des impôte.

Partout les mêmes résultats peuvent être, obtenus. PRODUCTEURS, COMMERÇANTS, CONTRIBUABLES

Pour réduire les charges qui vous acablent :

CONTROLEZ VOS FINANCES MUNICIPALES

Pour contrôler vos "finunces municipales, formez des associations de contribuables, adhérez à celles qui existent.

Pour former des associations de Contribuables.

demandez des renseignements d la

Federation Nafionale des Contribuatles

76, rue de Prony, Paris ( $17 \cdot)$ - Gal. jo-11

(1) En,vente 76, rue de Prony, Paris (17). Prix : 40 frs,

Plate 6 'Une victoire des contribuables parisiens,' January 1939, author's collection. 
asked the national government 'to improve and increase its supervision of the department and the municipality' and in particular to begin 'an immediate and rigorous ... investigation' of Saint-Étienne's financial accounts for the 1936, 1937, and 1938 fiscal years. The taxpayers insisted that the Saint-Étienne municipal council - described as a 'conseil municipal de Front Populaire' - adopt a 'clear policy' of economy and reduced expenses and create 'extra-municipal committees' of delegates chosen by the taxpayers themselves to oversee how this was carried out. They called for an answer to their requests by 15 June. $^{211}$

L'Action contribuable rejoiced at the formation of the Front Commun des Contribuables de Saint-Étienne and Lemaigre Dubreuil called it a milestone in taxpayer action.

This is the first time that all those who pay have stood shoulder to shoulder, and, in a stern and resolute demonstration of incomparable dignity, have affirmed their fierce resolve not to let themselves be eliminated for the benefit of another class or simply for the benefit of numerous middlemen and profiteers. The taxpayers no longer intend to be fleeced. They want to defend their rights. They want to save themselves from being ruined. ${ }^{212}$

In fact one of the signs in the Saint-Étienne crowd had read: 'In order to survive, we are forced to demand the reduction of expenses and the control of municipal finances' and L'Action contribuable printed a cartoon showing a worried Blum whispering to an uncomfortable Auriol: 'Alas, alas, this new front will be more popular than our own!'213

The taxpayer deadline passed without a response and the taxpayers began to circulate petitions to artisans, businessmen, and merchants, pledging them to close their shops and businesses as soon as and for as long as the Front Commun wanted. The petitions received thousands of signatures. The Front Commun alerted the city government of the intended 'strike' and sent a delegation to Paris to warn the national government to prepare for supplying the economic needs of the 200,000 inhabitants of Saint-Étienne. Premier Daladier and Minister of the Interior Albert Sarraut met with the delegation, promised an immediate investigation of the matter, and requested the Saint-Étienne municipal council to suspend all tax collections until the investigation had been completed. As a result, the Front Commun agreed to abandon its strike plans. ${ }^{214}$

At the departmental level also the Front Commun met with instant success. The Conseil Général de la Loire ordered all government departments to recommend 'feasible reductions and economies' to ease the economic impact of the budget voted the previous September. And the Conseil president invited taxpayer delegates to attend the sessions of the finance committee where he promised that their proposals and any other 'interesting suggestions' for budget reform would be examined carefully. In addition, he pledged to help them secure official authorization to delay their tax payments. Tax reductions, taxpayer oversight, and delays: on these three points, crowed L'Action contribuable, the Conseil Général has 'recognized the validity of our demands.' 215 
In Toulouse shopkeepers closed their stores for two hours on the afternoon of 6 July 1938 to attend a meeting at the Salle de l'Ancien Pré-Catalan to protest 'the senseless increase in government and municipal taxes.' To an overflow crowd of 35,000 citizens, one-by-one the orators denounced recent tax increases at all government levels, specifically targeting the centimes additionnels. 'Voilà nos ennemis!' declared the representative of the Union des Propriétaires, who painted their common fate in the bleakest of terms: poverty and ruin, a question of life or death! (L'Action contribuable chimed in that Toulouse shopkeepers had either 'to triumph or perish.') The president of the Toulouse Taxpayers' Association, the Association des Contribuables de Toulouse et de la Haute-Garonne blamed the high taxes on the excessive demands of the electorate, the compliance of elected officials, and the weakness of the public authorities, but other speakers were less generous, placing the responsibility squarely on the shoulders of the politicians. The tax troubles had arisen, so said one citizen, because Frenchmen had 'never had any leadership' in economic affairs. ${ }^{216}$

In the end Toulouse taxpayers voted to request a 15 percent reduction in departmental taxes, a 25 percent reduction in municipal taxes, the abolition of the business tax and the city tax (the octroi), a ceiling on land taxes, an adjustment of the personal property tax, and a reduction in the centimes additionnels. In addition, they proposed changes in the national income tax laws: the elimination of all deductions at the base and the reduction and unification of all the schedular rates. In short, a somewhat technical and sophisticated want list, demonstrating nonetheless that these folk were merchants, businessmen, and property owners of some substance and knew what they wanted. ${ }^{217}$

L'Action contribuable predicted a new era of taxpayer success:

Even if the politicians may misunderstand the meaning of this demonstration, all France understands it perfectly. In the north and the south, in the east and the west, the taxpayers - large and small, merchants, employees, members of the liberal professions - are watching with approval the action of the taxpayers of Toulouse. Everywhere there is immense hope. Everywhere there is the expectation of a new order. For the taxpayers of Saint-Étienne and Toulouse have broken with the old routine of pleading and whimpering. For the first time they have presented solutions at the same time that they have presented their complaints. By doing this they have proven what the taxpayers everywhere could accomplish once they know how to organize and act with a plan. ${ }^{218}$

Despite some success in the city council of Paris in 1939, the new era never arrived. To be sure, taxes always remained a concern with the middle-class shopkeepers, merchants, businessmen, and professionals who were the mainstay of the Taxpayers' Federation from Large to Lemaigre Dubreuil. But the Republic had changed its stripes, abandoning its red banners, its class rhetoric, and its economic experiments - in short, the Jacobin side of the Popular Front - for a more national and conservative tone and approach, especially in matters economic. Frankly, at the national level the taxpayers had little to complain about from the string of 


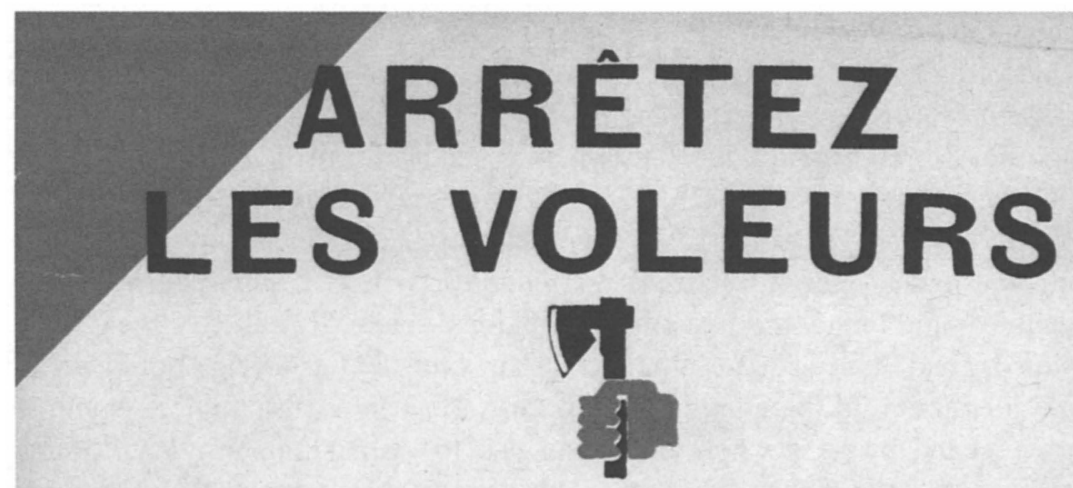

Depuis 1920 , les François ont versé pour to Défense Nationale 200 MILLIARDS

Molgré cet énorme effort, lo France, sons materiel suffisant et sons oviation, o été obligée de subir

\section{LA VOLONTÉ DE L'ALLEMAGNE}

Pas plus qu'hier, sa sécurité n'est ossurée.

OU EST PASSÉ L'ARGENT

Qu'on arrête les RESPONSABLES

$\mathrm{Si}$ on s'y refuse, nous comprendrons que la décomposition continue

et si on demande de nouveaux sacrifices

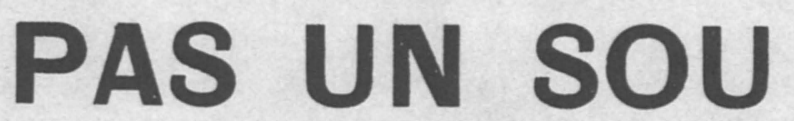

avant la création d'une COMMISSION D'ENQUÊTE dont feront partie les Contribuables

FEDERATION NATIONALE DES CONTRIBUABLES

26 rue de Prony. PARIS (15) - GALVANI jo-11

Plate 7 'Arrêtez les voleurs,' October-November 1938, author's collection. 
finance ministers, beginning with Georges Bonnet, who oversaw tax policy from 1938 onward, except to lament that taxes, like government expenditures, were always and everywhere much too high.

Then, too, foreign policy took on a new urgency for all Frenchmen with the Munich Agreement of September 1938, which so many believed narrowly averted war with Germany yet at the same time dealt France a devastating diplomatic defeat. Now in the pages of L'Action contribuable Lemaigre Dubreuil turned to the worry of war and France's fate on the international scene. He believed that 'never in its history had France had to submit to such a reversal of its foreign policy under outside pressure' and the attempt to turn this defeat into a triumph, as some in government and the press were trying to do, was 'to wish to transform a defeat into a disaster.' So serious was the foreign situation at that moment that Lemaigre Dubreuil suggested the 'extraordinary measures' of suspending the Chamber of Deputies and the Senate and establishing a government of Public Safety. ${ }^{219} \mathrm{He}$ dared to castigate the government for its unwillingness to stand up for its friends and allies in eastern Europe 'with all its risks and frightening sacrifices.' And he even taunted Premier Édouard Daladier, who called himself 'the last of the Jacobins,' that 'for lesser faults' than his the real Jacobins sent 'hesitant leaders and incompetent generals to the scaffold.' 'It was at that price, despite enormous mistakes, that they saved the Nation. ${ }^{, 220}$ In fact, the final federation broadside, pasted on Paris walls in August 1939, proclaimed France's borders to be at Danzig and earned Lemaigre Dubreuil the personal rebuke of Georges Bonnet, now France's minister of foreign affairs. ${ }^{221}$

With the declaration of war with Germany in September 1939 Lemaigre Dubreuil rejoined his reserve unit, took a leave of absence from the Bank of France, and suspended the activities of the Taxpayers' Federation. Amidst the farewells, he fired one last salvo against the 'system' in a letter to local federation leaders:

Our Victory was stolen from us once before. The political parties were successful in splitting apart those of us who had fought together in the war of 1914. Victory must not be snatched from us a second time. We must protect it. And we who have always remained outside of the political parties must be in the front line of that defense. Count on me if I return. ${ }^{22}$

Without doubt Lemaigre Dubreuil's term at the Bank of France was successful and coupled with his presidency of the Taxpayers' Federation had given him some standing as a fighter for the injured and threatened middle class during the Popular Front days. All that ended with the war, France's defeat, the German occupation, and the establishment of the Vichy government. For the Taxpayers' Federation was swept away by the French new order as part of the debris of pre-war France. But even if, quite clearly, Lemaigre Dubreuil was on to other things, the experience had revealed his passionate desire to speak out, to write, to organize, to lead, and, as important, to spend his money wherever he thought the interests of France and Frenchmen were concerned. 


\section{France's fall and the Vichy change}

\section{Mission to Romania, 1940}

In February 1940, Captain Lemaigre Dubreuil was assigned to the French military mission in Bucharest where he had served during the First World War. As the president of Georges Lesieur et ses Fils, an adviser to the Bank of France, the former president of the Taxpayers' Federation, and the new owner of Le Jour-Écho de Paris, he was superbly qualified to assess economic matters. And not surprisingly this was his first task. ${ }^{1}$ He was instructed to make estimates of Romanian supplies of petroleum, wheat, timber, and oleaginous seeds, and of Romanian shipments to Germany of these same items. In addition, he was to analyze the Romanian national budget and bond issues and to prepare a weekly summary of press articles concerned with economic affairs. ${ }^{2}$

As a member of the tripartite Little Entente, Romania was linked with the French system of alliances in eastern Europe, an obstacle to German and Soviet expansion in the Balkan peninsula. Romania's petroleum was of special importance. The French worried that Romanian petroleum might fall into the wrong hands as almost happened in the First World War. At the end of the First World War, Allied interests had supplanted those of Germany in Romania. Although the Versailles treaty stipulated that the investments and commercial holdings of the enemy powers in foreign countries would be used to compensate those countries for wartime damages, an Anglo-French agreement signed at San Remo in 1920 divided German petroleum assets equally between Britain and France, reversing the spirit and letter of Versailles. ${ }^{3}$ Yet little by little France allowed this decided economic advantage over Germany to slip. By 1935, Ernest Mercier, creator of the French petroleum industry, warned that Romania was sliding into the German economic orbit. ${ }^{4}$

In 1939 Germany, Italy, and Great Britain were Romanian oil's most important customers, followed by Czechoslovakia and France; in the twelve months between December 1938 and December 1939, German purchases increased 20 percent whereas French purchases decreased by almost the same amount. ${ }^{5}$ Still, French entrepreneurs remained active in the Romanian petroleum industry. In 1940, French companies directly controlled 16.6 percent of Romania's oil industry and French capital accounted for 40 percent of the total capital investment in 
Romanian petroleum while German capital investment in Romanian oil was almost non-existent. ${ }^{6}$

Nevertheless, by increasing its total share of Romanian exports, Germany was assured of an uninterrupted supply of petroleum. Romania bought where it sold; as Romanian imports from Germany increased, Romania was tied tightly to the German Grosswirtschaftsraum. This made a refusal to sell petroleum to Germany virtually impossible. From 1934 to 1938 German imports from Romania increased steadily, except for a dip in 1937; in 1934 German purchases accounted for 15.5 percent of Romanian exports; by 1938 the figure had risen to 36.8 percent. German exports to Romania followed a similar pattern; in 1934 German goods accounted for 16.6 percent of Romanian imports; in 1938, 26.5 percent. On the other hand, from 1934 to 1936 French imports from Romania dropped from 11.1 to 5.9 percent; in 1937 and 1938 the figure rose to 6.1 and 7.7 percent respectively. French exports to Romania dropped to 4.1 percent in 1935 , rose to 8.1 percent in 1936, and then dipped to 4.7 percent in $1938 .^{7}$

In part the resurgence of German economic influence in Romania was the simple result of the economic geography of central and southeastern Europe: the Danubian region and the eastern Mediterranean were the natural markets for Romanian goods. It was also the result of a concerted effort by the German government to increase its influence in the Balkans by economic means. To stimulate trade, Germany paid high prices for Romanian petroleum as well as for the agricultural products so important to the Romanian economy. ${ }^{8}$

Franco-Romanian trade was difficult to justify in economic terms. France only purchased foreign agricultural products in times of bad harvests at home. And in order to sell petroleum to France, Romania had to compete with American or Middle Eastern oil. Political concerns, however, oftentimes outweigh economic disadvantages. As early as 1931, Romanian pleas for Anglo-French investment indicated a growing fear of German economic domination, and in the mid-1930s the Romanian government agreed to ship petroleum to France in payment for military equipment at a considerable financial sacrifice. ${ }^{9}$ The French government, on the other hand, appeared unwilling to revise its national commercial policy in order to preserve and strengthen its economic commitment to Romania. Perhaps the French counted unwisely on the individual and collective action of the Balkan governments to protect themselves against economic subjugation by Germany. More likely, they failed to recognize the importance of the German economic threat or how quickly this economic influence could be turned to political advantage. France persisted in the belief that its political and cultural influence alone was strong enough to keep Romania linked to France.

In the space of a year, the French political position in Romania collapsed. The Munich Agreement of September 1938 partitioning Czechoslovakia cast doubt on the value of France's pledges to its allies, while the Nazi-Soviet Pact of August 1939 gained an ally for Germany but lost one for France. German representatives in Bucharest warned Romanian Foreign Minister Grigore Gafencu that only the 'tutelary friendship, of the Reich could protect Romania from any sacrifices in the future.$^{10}$ Having lost the economic war in Romania by default, the French were well on their way to losing the political war. 
Even after the outbreak of the European war in September 1939, Lemaigre Dubreuil still believed that all was not lost for France in the Balkans. The inaction on the western front was heartening: it provided the necessary time to reverse French policy and to begin to restore French influence in Romania. And this is why he sought the assignment in Bucharest. However, nothing turned out as he hoped it would. To begin with, his economic fact-finding mission was more difficult than he had expected. The embassy's commercial attaché, Roger Sarret, and the French government's delegate for petroleum affairs, Léon Wenger, told him in 'astonishingly brutal terms' to steer clear of all the questions concerning petroleum. Wenger even threatened to alert higher-ups, who might make things unpleasant for him, were he to disregard this advice. Although Lemaigre Dubreuil recognized that he was only a 'simple captain' in rank, he knew he was much more than that in terms of position and experience and was a 'bit astonished' at their 'absolute refusal' to give him the information he needed. In a country where 'petroleum dominates everything,' he concluded that doing his work would be 'impossible,' his accomplishments 'nothing.' So he told Jean Rigault in Paris - one of his editormanagers at Le Jour-Écho de Paris - to pull some strings to have the ambassador in Bucharest 'ordered' to allow him to study 'every economic issue, especially petroleum.' 11

The angry words and the refused information might have been the understandable reaction of civilian professionals to an unusually intrusive military officer. Lemaigre Dubreuil could be headstrong and uncompromising, even akin to a bull in a china shop. His own business career and his presidency of the Taxpayers' Federation had accustomed him to giving orders, not taking them. Still, he wondered if this resistance to outside scrutiny was an attempted cover up. As he put it to Rigault: 'You can surely imagine the reasons why no one would want me to document the petroleum deliveries made to Germany since the start of this war by companies administered by Frenchmen.' He was willing to let the china chips fall where they may and on his own he began to ferret out the information he needed. He was convinced that all of this went way beyond individuals: 'It is the policy of this zone that is at stake.' 12

His first report on the Romanian economic situation was ready less than two weeks after his disagreeable conversation in the office of the commercial attaché. He noted that while it had taken France three months of painful negotiations to secure a payments agreement with Romania (31 March 1939), the Germans had achieved the same result within three weeks (23 March 1939). This agreement, if it is fulfilled,' he warned, 'would make the Romanian economy dependent upon the German economy.' ${ }^{\prime 3}$ Actually, the economic talks which had led to the March 1939 German-Romanian treaty had begun in winter 1939. Nevertheless, Helmut Wohlthat, one of the German negotiators, was also certain that, if the Romanians kept their pledges 'Germany would indeed achieve predominance in Romania., ${ }^{14}$

In December 1939, the Romanian minister of finance had announced a new exchange rate between Romanian and German currencies, which prompted Lemaigre Dubreuil to reflect that 'the battle of the mark against Allied currencies was won. ${ }^{15}$ The currency exchange rate, fixed at 44.75 lei for a mark, reduced the 
debt owed by Germany to Romania and enabled Germany to buy Romanian goods at a rate 11 percent cheaper than previously, a definite advantage over British and French competitors. ${ }^{16}$ French Ambassador Adrien Thierry reportedly protested this 'unjustified favor to Germany, which was incompatible with neutrality.' But German policymakers, while acknowledging their victory, saw the new exchange rate as only partially meeting their demands. ${ }^{17}$

Finally, Lemaigre Dubreuil concluded that even the Franco-Romanian petroleum contract of 21 April 1939, made possible by the payments agreement of the previous month, was being evaded. He advocated waging an 'economic war' in order 'to prevent the Germans from receiving important quantities of fuel oil. ${ }^{\text {' }} 18$

Lemaigre Dubreuil's criticism of what he termed the 'negative' policy of the embassy did not win converts to a more vigorous policy. Three days after submitting his report he was told that Ambassador Thierry desired his recall because he had solicited information outside of embassy channels and openly disapproved of embassy policy. Lemaigre Dubreuil remarked caustically that this was the first time since his arrival that the ambassador had taken notice of him. He defended his research methods: an inability to find the required information at the embassy had made other tactics - such as talking directly to Romanian businessmen, bankers, and government officials - necessary. He attributed his embarrassing predicament to the obstinate refusal of some French officials to let him study certain questions. And he wrote to Colonel Joseph de Mierry, a staff officer at the war ministry in Paris, requesting a transfer home which he hoped could be processed before Thierry finalized his recall. ${ }^{19}$

By mid-March there was no word on his recall or on his transfer request. Perhaps someone had interceded for him at the Quai d'Orsay, touched by Rigault's string pulling, or perhaps General Maxime Weygand, who knew Lemaigre Dubreuil by reputation alone, had put in a good word. As military commander of the eastern Mediterranean theater, Weygand directed the work of the French military missions operating with the Turkish, Greek, Yugoslav, and Romanian armies. And Weygand promoted an active policy in the Balkans. In a December 1939 memorandum he had outlined his project for Allied military intervention in the Balkan peninsula. By taking the initiative, Weygand explained, 'we shall place two decisive factors on our side: time and action.'

The time has therefore come for France and England, which have until now left the field free to the propaganda and open threats of Germany, to intensify and weld together the defense of the Balkan powers by affirming their will to participate in this defense, by reinforcing [Balkan] armaments, by coordinating their plans, and by supporting directly with their own troops the defense of [Balkan] territories. ${ }^{20}$

To continue a policy of 'abstention' in the Balkans, Weygand concluded, would vitiate the pledges to the Balkan states, contribute to the collapse of the Balkan bloc, and miss an opportunity to create a new front. ${ }^{21}$

Lemaigre Dubreuil believed that the lack of French initiative in Romania was 
symptomatic of the general malaise of French foreign policy. The failure of France to take an active part in the Russo-Finnish winter war, for example, he thought was 'shameful' and pointed up 'the general abdication of our country.' In his letters to his brother-in-law and to the managerial team at Le Jour-Écho de Paris - Louis Goury du Roslan, Jean Rigault, and Jean-Camile Fernand-Laurent - this message was repeated over and over again. Le Jour-Écho de Paris must oppose the policy of flirting with France's enemies - Hungary, Bulgaria, the Soviet Union - and abandoning France's friends - Finland. As for Romania, it was being lost to the Germans. What was needed was to create ties 'with the pays réel: the only [Romania] ... favorable [to France]. ${ }^{, 2}$

Moreover, Lemaigre Dubreuil continued to believe that 'certain private [French] interests' were using the shield of national defense to keep 'a sort of monopoly' on the petroleum industry and rid themselves of intruders. And Léon Wenger personified all that he distrusted. His letters were filled with contempt for this man, who, he alleged, 'deceives not only the ambassador but the general.' He was convinced that Wenger 'directs French policy for his own personal interests.' 23

In 1935, the French government had delegated Léon Wenger to undertake all purchases by France of Romanian petroleum through the intermediary of Pétrofina Française, a subsidiary of the Société Financière Belge des Pétroles (Pétrofina), a Franco-Belgian concern of which Wenger was an administrator. Wenger made his first major agreement with the Romanian government in spring 1936, when he arranged to buy Romanian oil in exchange for French military equipment. The contract was canceled three years later. ${ }^{24}$ Despite the early cancellation, Lemaigre Dubreuil was convinced that the profits made by Pétrofina Française were 'completely out of proportion to the role of intermediary that it had played.' Wenger's private business connections, he declared, deprived France of an objective and independent on-the-spot observer essential for the proper conduct of business operations where politics and diplomacy were involved. He accused Wenger of instilling a false sense of security in French business and government circles by pretending that Romania's oil was being drained off by the Allies, leaving Germany without suppliers. To the contrary, far from receiving the lion's share of the oil, the Allies were getting the lamb's portion. ${ }^{25}$

Lemaigre Dubreuil was equally critical of Wenger's role as a technical adviser. In September 1939, the French ministry of public works assigned Wenger the task of preparing for the destruction of the Romanian petroleum industry should the oil fields be in danger of falling into enemy hands. Wenger's report outlined two methods for accomplishing the task: one plan required 24 hours, the other a minimum of ten days. The Wenger report won the approval of General Maurice Gamelin, Commander-in-Chief of the French army, who authorized Ambassador Thierry to proceed with the necessary preparations with Wenger himself in charge of the operation. ${ }^{26}$ Lemaigre Dubreuil considered the plans fallible and that Wenger, as technical, military, and financial adviser rolled into one, had successfully 'deluded' both the French government and the military command. ${ }^{27}$

Finally, Lemaigre Dubreuil discovered that Concordia, the second largest refinery in Romania and a subsidiary of the Société Financière Belge des Pétroles, 
had continued to furnish petroleum to Germany until December $1939 .{ }^{28}$ Léon Wenger had been a vice-president of Concordia until the end of 1939. Lemaigre Dubreuil concluded that 'the private interests of $\mathrm{M}$. Wenger are too entangled with the French interests he oversees to permit him to inform our government and to direct his action with the necessary impartiality.' He recommended that the French government designate an independent adviser who would confine himself to the commercial and financial aspects of the petroleum industry, leaving the technical and military problems to other authorities. ${ }^{29}$

Lemaigre Dubreuil's assessment was surely influenced by his own situation: sent to Romania on a task of some importance for the French army, then blocked by his own countrymen, especially Wenger, from carrying it out. Could his judgement have been impaired by his own business connections? Georges Lesieur et ses Fils did have an investment in the Société Générale des Huiles de Pétrole, and Lemaigre Dubreuil served as a director of that company from 1935 to 1937, after which Paul Lesieur took his seat on the board. ${ }^{30}$ The creation of the Sociéte Générale des Huiles de Pétrole, however, was the mechanism by which the AngloPersian Oil Company had bought out Lesieur's interest in the petroleum business, so that Lesieur held no more than a 10 percent interest in that company and no voice in its management even though a Lesieur executive had a courtesy appointment on the board of directors. In any case, in Wenger's official capacity, he acted in the general interest of all French oil companies, including the Société Générale des Huiles de Pétrole; his policies in Romania were geared to maximize their profits and minimize their risks. So by bucking Wenger, Lemaigre Dubreuil really acted against his own financial interests, whereas Wenger was now asked to destroy the very industry that he had had a hand in creating, unhappy and ironic dilemmas in wartime whenever personal and national interests collided.

Under Vichy the collaborationist Je suis partout tallied up Lemaigre Dubreuil's concern with Romania to the internal struggles of cutthroat capitalism, not outraged patriotism. Ambassador Thierry, a Jew, was portrayed as an agent of American capital while Lemaigre Dubreuil, now unmasked as a conspirator in the November 1942 Allied invasion of North Africa, schemed for the British. ${ }^{31}$ The truth was quite different. Adrien Thierry, married to Nadine de Rothschild, was a career diplomat who had served seventeen years in the London embassy and developed a genuine fondness for Britain. After shorter assignments in Madrid and Athens he was appointed ministre plénipotentiaire to Bucharest in $1936 .^{32}$ The worst epithet that Lemaigre Dubreuil could hurl at him was 'a contemptible fellow,' certainly reflecting his sensitivity at being ignored, even snubbed by the ambassador from the very first, then the blow to his pride at Thierry's request for his recall. Moreover, Thierry held Wenger in high esteem whereas Lemaigre Dubreuil was sure that French interests were not in the best or most secure hands.

Nevertheless, it would be difficult to fault Thierry for wanting to replace an officer, who had become troublesome. The military staff of the French embassy at Bucharest expanded rapidly after the start of the European war, resulting in confusion and friction between military officers and the civilian staff. Part of the problem was that the distinction between civilian and military responsibilities 
became blurred; soldiers were now interested in matters that in peacetime had been the exclusive preserve of the embassy's civil servces. Moreover, the normal lines of communication were broken; the soldiers often ignored embassy channels, preferring to report directly to their superior officers in Bucharest or Paris. Unfortunately, Jacques Lemaigre Dubreuil, Adrien Thierry, and Léon Wenger formed one dysfunctional trio among many.

On 24 March, Lemaigre Dubreuil left Bucharest for Paris armed with the reports that he hoped would prove the necessity of changes in French policy in Romania. Whether he had been recalled or whether Colonel de Mierry had obtained a transfer for him is uncertain. Nevertheless, once in Paris he sent his reports directly to Weygand's headquarters in Beirut since he knew that the general wanted a forward policy in the Balkans. Indeed, Weygand wrote Gamelin three days later: 'I am convinced, as I already was in the month of December that it is indispensable to give a resolution and élan, both of which have been lacking until now, to our diplomatic and economic action in the Balkans. ${ }^{33}$ In Lemaigre Dubreuil's reports he counseled the immediate replacement of Thierry, since 'our present representation is incapable of carrying out a fiercely energetic policy.' He suggested the modification of the 1939 payments agreement with Romania, the creation of a Franco-Romanian company for joint exploitation of petroleum and mineral deposits, the formation of a permanent economic mission to Romania, and the continuation of arms shipments to that country. ${ }^{34}$

When Germany wanted to win in Romania - and the agreement of December 1939 was a 'Romanian Munich' for the Romanian economy - time was not wasted bickering over details on this or that product. Germany played to win ... [and] demanded a parity of the mark to the lei which gave her an advantage over the Allies in every business deal ... We must adopt the same tactics. ${ }^{35}$

To improve the Allied economic position throughout the Balkans, Lemaigre Dubreuil suggested the appointment of an economic mission headed by an old economic hand such as Guillaume Georges-Picot or Henry Du Moulin de Labarthète. This senior head of mission would supervise all the commercial attachés in Southeastern Europe, coordinate Allied economic policies, and initiate strong measures to establish the Allies as willing partners of the Romanians and vigorous competitors of the Germans. He argued that the risk of a shooting war implicit in such a policy was minor compared with the risk of losing Romania to the Axis.

It is certain that economic action vigorously pursued must lead to war in Romania. The Germans will find themselves obliged to unleash this war, which in reality, will have been decided by us. This situation will permit us to bring our alliances into play. ${ }^{36}$

At the request of Premier Paul Reynaud, Weygand visited Paris in April to attend a series of briefings with government and military officials. He also 


\section{The assassination of Jacques Lemaigre Dubreuil}

conferred with Lemaigre Dubreuil and was apparently impressed by the latter's analysis of the Romanian situation. Weygand appointed him to his general staff with the task of explaining Weygand's Balkan policy to the government. ${ }^{37}$ Two days after this conversation Weygand formally submitted his plans for Allied action in the Balkans which strongly endorsed what Lemaigre Dubreuil had been saying for weeks.

If we continue a laisser faire policy, Germany will achieve the conquest of Romania à la mode hitlerienne, that is to say, without a fight ... A closely coordinated Balkan policy in all areas, put into operation without delay by France and England is alone capable of breaking the German hold on a country whose integrity and independence we have guaranteed ... I regard it as indispensable to put our embassy in Bucharest in a position to lead the struggle by endowing it with a real general staff, composed of active and competent people under the command of an energetic leader capable of proposing, then applying the measures needed to beat Germany on her own terms. This means superior propaganda with financial, economic, industrial, and military cooperation ... capable of restoring Romania's confidence in its natural protectors and putting its interests in harmony with its desires. ${ }^{38}$

Weygand avoided any suggestion that such a program might bring about an immediate military confrontation and rather expressed the hope that if the program was carried out successfully, it might open the way for a purely preventive Allied military intervention at some future date. ${ }^{39}$

Although Lemaigre Dubreuil now had the support of Weygand, his problems were far from over. His meetings with Reynaud and Undersecretary of State Paul Baudouin proved fruitless. Baudouin appeared to endorse the Weygand-Lemaigre Dubreuil proposals but he confided that Reynaud would make no decision concerning Ambassador Thierry at present; the premier had been in power for only three weeks and was still feeling his way cautiously. In the meantime Lemaigre Dubreuil continued his round of interviews, hoping to drum up enthusiasm in political and military circles for the Weygand project. Finally the situation seemed to break in his favor: Ambassador Thierry arrived in Paris in late April prepared 'to plead his case' and the showdown appeared imminent. ${ }^{40}$

Although Reynaud was now willing to oust Thierry, the problem was to find a replacement, not an easy task in wartime and particularly when he was preoccupied with the Norwegian campaign where he had decided to try to break German supply lines. The opportunity was allowed to slip by and Thierry returned to Bucharest untoppled. And nothing was done about the proposed reinvigorated economic mission to the Balkans. Although Lemaigre Dubreuil remained optimistic, the truth was that the Balkan project had collapsed for lack of support. ${ }^{41}$

It is easy to understand why any active policy in Romania or the Balkans was quietly shelved after the Norwegian campaign turned into a disaster. Balkan problems were too jumbled to give Reynaud a sure success. Nevertheless, he did send a personal envoy to Bucharest on a fact-finding tour; on his return his emissary 
recommended replacing the civilian and military leadership in Romania and subordinating the entire French mission to Weygand, still the military Commander-in-Chief of the eastern Mediterranean theater. Presented in early May, these suggestions came too late to be of any use to Reynaud who was now engaged in the political and military decisions of the battle of France. ${ }^{42}$ Still, as Lemaigre Dubreuil had recommended, the military took over the operation for the destruction of the Romanian petroleum industry; Wenger handed over his technical plans to General Étienne Delhomme, the military attaché in Bucharest, and returned immediately to Paris. ${ }^{43}$ Lemaigre Dubreuil could do no more. He wrote Weygand: 'I asked for another conference with [Reynaud] or his chef de cabinet, making it clear that I had to let you know once and for all what the government's intentions were concerning Romania.' But by week's end his efforts had resulted in no commitments. ${ }^{44}$

The Romanian episode was closed. France was in the midst of what General André Beaufre has called 'the drama of 1940.' Lemaigre Dubreuil returned to his regiment, which had begun combat action the second week in May. And Reynaud was soon to summon Weygand from Beirut (on 19 May) to assume the overall command of the French armies facing the German onslaught. Within the short space of a week the priorities had changed and Bucharest seemed unimportant and distant compared with the tragedy unfolding in France. Yet by all accounts Lemaigre Dubreuil had accomplished quite a bit in a short space of time, especially for a political and military outsider. On his own, he had convinced Weygand of the need for a shake-up in Romania; then, as a member of Weygand's staff, he had persuaded Reynaud to begin to re-evaluate Balkan policy. For the former president of the Taxpayers' Federation and the controversial member of the Conseil Général of the Bank of France, accustomed to doing battle with the powers-that-be rather than working with them, this was a notable achievement and sure testimony to his patriotic fervor and national spirit.

\section{Le Jour-Écho de Paris}

While in Romania, Lemaigre Dubreuil relied for political support and information from his editor-managers at Le Jour-Écho de Paris, the Paris daily newspaper he had purchased in September 1939 from Léon Bailby. Two of them, Jean Rigault and Louis Goury du Roslan, had worked with him at the Taxpayers' Federation, Rigault as secretary-general charged with policy, publicity, and public relations and Goury du Roslan as fund-raiser and financial manager. The third team member was Jean-Camille Fernand-Laurent, Bailby's former senior editor who remained at this post with the title of director. It was Lemaigre Dubreuil's initial intention to use the newspaper with its impressive offices on the Champs-Élysées to expand and extend taxpayer activities. But the unhappy odyssey of Le Jour-Écho de Paris paralleled that of many French businesses caught in the unpredictable circumstances of war, then the French collapse, and finally the establishment of the Vichy new order. What began as a business opportunity for Lemaigre Dubreuil, given Bailby's fear of the coming war and all its uncertainties, turned out to be a financial disaster and 
perhaps a political mistake. At the time, of course, all this was impossible to foresee.

Acting for himself and his brothers-in-law, Lemaigre Dubreuil purchased the newspaper with the encouragement of Rigault, who knew Fernand-Laurent (and Bailby's worries) and had worked closely with him on taxpayer issues for more than two years while Fernand-Laurent was both a Le Jour-Écho de Paris editor and a member of the Chamber of Deputies. For a while Bailby continued as the salaried political director of the newspaper, but he could not adjust to the new situation and soon complained that certain 'moral clauses' of the sales contract had not been fulfilled, making it impossible for him to carry on his work. He began legal action against the new owners of Le Jour-Écho de Paris, then left for Nice and, after France's fall, started a new publishing venture with the ultra-Pétainist weekly, L'Alerte. ${ }^{45}$

The political issue that separated Bailby and Lemaigre Dubreuil was the coming war and Lemaigre Dubreuil's insistence on a hard line in foreign policy. This meant a militant support for France's friends and the no-nonsense denunciation of its foes, all of which, as his letters to Paris from Romania and his reports to Weygand made clear, edged France closer to war. France's quick military defeat in May-June 1940 and the impending occupation of Paris by the Germans turned the world of Le Jour-Écho de Paris upside down. The newspaper closed its offices and moved to Poitiers, then Bordeaux, following the fleeing French government, and finally after the armistice to Clermont-Ferrand. At each stop it continued publishing on borrowed presses with its files and archives, hurriedly boxed up almost single-handedly by Rigault in the flight from Paris, following in its train. ${ }^{46}$ In August, Lemaigre Dubreuil requested permission from French officials to return Le Jour-Écho de Paris to Paris in the full knowledge that the request had to be approved by the German authorities. He explained that the newspaper would pursue the work of 'national renovation with all the political risks that this would involve' and move France, just as he had hoped to do before the war, 'toward a new, political, social, and economic order.' Writing on behalf of the newspaper's board of directors, Goury du Roslan asked if Germany really wanted 'a new France, directed by new men, and eventually re-established in its sovereignty'? If so, the task of Le Jour-Écho de Paris would be to lead Frenchmen to 'a new understanding of the realities,' that in itself quite a 'revolution in thinking' to accomplish. For this to happen the newspaper required complete freedom in the choice of its staff members, once the German press services had approved a list of candidates; complete freedom of the press "within the limits of normal censorship. ${ }^{47}$ These conditions were never accepted and Le Jour-Écho de Paris never returned to Paris.

From October 1940 to July 1941, Le Jour-Écho de Paris located in Marseille where it was still not free of German pressure. In December 1940, Lemaigre Dubreuil suggested to General Weygand, now the Vichy government's delegate in French Africa with headquarters in Algiers and vast military, political, and economic responsibilities from Tunis to Casablanca and from Algiers to Dakar, that Le Jour-Écho de Paris come to Algiers and transform itself into a newspaper for France's African empire. In his reasoning an empire newspaper would aid in 
keeping French Africa together as a 'solid bloc,' able to resist anything that might shatter its unity and firm in its task of 'the defense and salvation of the Metropole.' These were ideas at the core of Weygand's mission given the devastating British attack on the French fleet at Mers-el-Kébir off the Algerian coast in July and the failed yet bold Anglo-Gaullist assault on Dakar in September. In addition and significantly, however, Lemaigre Dubreuil spoke of the need 'to unite the spirit' of the various peoples of North and West Africa so that now as well as in the future they would remain 'independent, free, and proud at our side.' And to investigate and act in the economic sphere as well. As the newspaper's directors, he proposed Rigault and Fernand-Laurent, and for the newspaper's financial support he pledged his own money and that of his brothers-in-law. ${ }^{48}$ For whatever reason this project was dropped.

In May-June 1941, Fernand-Laurent resigned from the editorial team, unwilling to yield to the 'censorship of Berlin,' and in July, Rigault, who had assumed the mantle of the overall direction of the newspaper, returned Le JourÉcho de Paris to Clermont-Ferrand. He was constantly harassed by the censor, even though he had agreed to run a weekly page devoted to Marshal Pétain's 'national revolution.' Nevertheless, Vichy authorities suspended the newspaper's publication in November 1941 (and demanded and got Rigault's resignation as well) after Le Jour-Écho de Paris printed a letter of congratulations written by President Raymond Poincaré in 1918 to Marshal Pétain at the moment of Pétain's 'elevation' to the dignity of a marshal of France. The letter was so patriotic in tone and the contrast between the past and the present so unsettling that Vichy found it provocative and thus unacceptable. After Rigault's departure Le Jour-Écho de Paris's suspension was lifted and the newspaper limped along for another four months, ceasing publication once and for all in March $1942 .{ }^{49}$

For Lemaigre Dubreuil the Le Jour-Écho de Paris episode was expensive and politically taxing. What might have been a great benefit to the Taxpayers' Federation on its march to becoming a solid and respectable middle-class pressure group turned instead into a personal, financial, and politically sensitive trek across Vichy France, apparently winning him no friends in the corridors of power on either side of the Mediterranean.

\section{Georges Lesieur et ses Fils}

Lemaigre Dubreuil left for the front with the First Armored Regiment at the end of May 1940 in command of two squadrons. Sent on a reconnaissance mission in the direction of Troyes, he was captured by the Germans at Nogent-sur-Seine after an unequal match between a fully armed Panzer division and three half-finished French vehicles without gun turrets, cannon, or machine guns that he had personally commandeered from the Panhard and Renault factories. He managed to escape at Château-Thierry (on 17 June), made his way to Paris, already vacated by the French government, and then to his brother's home in the Haute-Vienne. For his bravery, he was awarded the croix de guerre avec palmes. ${ }^{50}$

Even though he had experienced defeat and capture first hand, Lemaigre 
Dubreuil was stunned at the armistice and the inability of France to resist further. He had few illusions about a France under German occupation or a France under a new regime at Vichy. In fact, after his first visit to Vichy and its political nerve center, the Hôtel du Parc, he told Weygand, now minister of national defense in Pétain's cabinet and anti-parliamentarian as ever, that 'if it was necessary to count on the competence of these people to save the country,' - and here he named Paul Marchandeau, Lucien Lamoureux, Camille Chautemps, and Pierre Laval, political war horses of the Third Republic - 'it would be better not to try.' What he hoped for was a completely new regime, not manned by the old guard of 'yesterday's soldiers' who had led France militarily astray through 'lack of civic courage and incompetence' - and this to Weygand! - and 'yesterday's politicians' who had done the same thing politically through 'cowardice or endless and meaningless discussions (byzantinisme).' Still, since the government had asked for an armistice and decided to remain in France, he thought it absolutely necessary that the national economy remain in French hands. If Frenchmen failed to assert or reassert that control, the Germans would surely take it from them 'under the pretext of restoring the order that we were unable to restore by ourselves.' And he argued that economic issues of money and of commerce should take precedence over the demobilization of France's armies and the return of refugees to their homes. ${ }^{51}$

As for his own part in the French recovery, Lemaigre Dubreuil turned back to Georges Lesieur et ses Fils and the story of this family business after the fall of France and during the Second World War - in contrast to that of Le Jour-Écho de Paris - is a rather successful account of the adaptation of a French company to the Vichy change. The decisions of Lemaigre Dubreuil and his brothers-in-law in 1940 combined patriotic sentiment, economic opportunity, and entrepreneurial boldness. There was no way of knowing, of course, how these choices would play out over time, especially since, even after the Franco-German armistice, France and its empire, defeated and fragile, were still very much at risk in a world at war.

In 1939, Georges Lesieur et ses Fils was a French leader in the production of vegetable oils for edible or industrial use and household and hand soaps: the brand name Huile Lesieur was widely known and respected. The company had capital assets of 52 million francs and the plant at Couderkerque-Branche, two miles from the port of Dunkirk, processed 120,000 tons of peanuts (in 1938) and produced 45,000 tons of unrefined peanut oil, 40,000 tons of refined peanut oil, 55,000 tons of oil cakes, and 11,000 tons of soap. Since Dunkirk was the scene of bitter fighting and widespread German bombing during the desperate Allied defense of the port and the 'heroic' re-embarkation of Allied troops - the 'miracle of Dunkirk' Lesieur factories were severely damaged. Nevertheless, by the end of summer 1940 , Couderkerque-Branche was back in operation, even though now located in German-occupied France, attached to an economic district with headquarters in Brussels, and responsible to the Militärbefelshaber for Belgium and northern France..$^{52}$ The difficulty, of course, was not only to produce but to ensure that Lesieur products would not be sent to Belgium and eventual German use rather than to relieve the desperate conditions of occupied and unoccupied France. ${ }^{53}$

Before the war Lesieur had been a northern French company with an especially 
important market in Alsace-Lorraine. It imported peanuts from West Africa and the East Indies for processing at Dunkirk, then sent its products to distribution centers at Saint-Ouen (Seine), Reims, Nancy, and Strasbourg. When the Allied blockade cut off its maritime commerce and colonial links, Dunkirk began to die as a port city and Lesieur with it. To keep in business Couderkerque-Branche began manufacturing condiments and detergents, following the directives and in cooperation with Vichy's Comité d'Organisation de l'Huilerie. ${ }^{54}$

To supply metropolitan France with food was a prime concern of both German occupation authorities and Vichy administrators. And ensuring adequate food supplies in wartime had also preoccupied the Republic and its businessmen. In September 1938, vegetable oil producers created the Société d'Importation et de Répartition de Produits Oléagineux (SIRPO) under the auspices of the French ministry of commerce to act as the sole importer of oleaginous products - mainly the West African peanut crop - which it then efficiently parceled out on a quota basis to the various French companies engaged in the vegetable oil trade from Dunkirk to Marseille; SIRPO also regulated prices and set up an aid program for member companies that might be disabled in time of war. ${ }^{55}$ And in March 1940 Minister of Colonies Georges Mandel, a tireless promoter of the industrialization of overseas France, asked vegetable oil producers to consider building factories in Senegal to process the peanut crop on site, for this would shelter the French industrial plant in wartime and perhaps reduce production and transportation costs. ${ }^{56}$

Vichy revived Mandel's scheme. However, African factories were now seen as replacing the blockaded channel plants as production, storage, and distribution points for goods destined for French wartime survival and postwar renewal. Endorsed by the ministries of food and commerce and with the support of Pierre Boisson, the vigorous and pro-industrialist governor general of French West Africa, the project was presented to SIRPO in October 1940, where it received lukewarm backing from all but Lesieur. Lemaigre Dubreuil alone agreed to construct and operate factories in Dakar, Casablanca, and Algiers, if the government consented to provide a 'political guarantee' of the Lesieur project in view of the 'considerable political risks' involved, to establish a production and export quota favorable to Lesieur, and to admit Lesieur oil tax free into the metropolitan market. Vichy accepted the Lesieur offer (and its conditions) and agreements were signed between the Lesieur company and the ministry of colonies and the residency of Morocco in January $1941 .{ }^{57}$

Lesieur plans called for the construction of a factory at Dakar for the crushing of peanuts and the extraction of their oil, a refinery at Casablanca for processing the unrefined oil from Dakar, and a third factory at Algiers to supplement the work of Casablanca and to manufacture soap. Over time Lesieur would dismantle and ship entire sections of the Couderkerque-Branche factory to Africa with the authorization of the German occupation authorities who encouraged this relocation, in the main because French money was being spent to ensure France's food supply. And in the end Lesieur transferred almost 8000 tons of equipment to North and West Africa. Despite an energetic beginning, however, delays and complications retarded the progress of the work. Finding new equipment in wartime was difficult, 
even from an America interested in selling to French colonial customers; and Germany demanded priority on everything industrial. In addition, the shipping lanes between the Metropole and overseas France were insecure and the British navy seized at least one ship - the Isac - carrying material destined for LesieurAfrica. As a result, Dakar did not begin production until 1943 and Casablanca and Algiers, interrupted by the Allied landings in November 1942 and the continued vicissitudes of war, until 1944 and 1948 respectively. ${ }^{58}$ Nevertheless, this was a remarkable record of industrial activity in a world at war. For Lesieur, the African venture might have seemed a matter of economic life and death, its initial African investment (of over 60 million francs) a forced gamble on the future. As it turned out, however, Lesieur benefitted from Lemaigre Dubreuil's risk taking: its capital assets increased by 30 million francs between 1939 and 1941, and by another twenty million francs between 1941 and 1946, boosted by the course of the war. What is more, the company was poised for a vigorous postwar expansion with a solid base of operations (or so it seemed at the time) in Greater France.

Politics also bedeviled the Lesieur relocation. Less than two weeks after signing the African agreements, Vichy's ministry of colonies issued a directive forbidding Senegalese authorities from issuing commercial licenses to companies that had not already exported peanut oil from West Africa to France or Algeria. This clearly affected Lesieur. Eight months passed before this matter could be resolved so that the Lesieur project could go forward. The end result, however, was to reduce the already agreed-upon Lesieur export quota from Dakar. Later in 1941 an interministerial conference held at Vichy challenged the wisdom of African industrialization schemes at a time when Lesieur was already firmly committed to its project and had invested a considerable amount of money. At the same time, some of the original SIRPO opponents of the Africa project (primarily Marseille vegetable oil companies) had had second thoughts and now worried about a Lesieur colonial advantage. To counter this competitive edge, the ministry of finance required Lesieur to offer SIRPO the opportunity of buying into Lesieur-Afrique Dakar, capitalized at thirty million francs, up to an amount of eight million francs. But this did not stop the unfavorable press reports - first in France, then in Germany arguing against West African industrialization and in specific against the building of vegetable oil factories in Senegal. ${ }^{59}$

Lesieur tried to keep its factory at Couderkerque-Branche as far from the military and political battlefields of wartime as possible, but this was tough to do. Lesieur continued doing business with its pre-war customers insofar as the supplies of its products lasted and the network for their distribution still functioned. It complied with German requisition orders for glycerine in September 1940 and with the economic terms of the armistice agreements on vegetable oil agreed to between the French State and the German government at Wiesbaden. The delivery of all these goods, however, was made indirectly, that is, in Lesieur's name by SIRPO which fulfilled German requisitions and Vichy requests on behalf of all its member companies whether sinistrés ('affected by the war') or not. Long after Couderkerque-Branche had ceased production, SIRPO delivered its share of these obligations to Germany. ${ }^{60}$ 
After the November 1942 Allied landings in Morocco and Algeria and the disclosure of Lemaigre Dubreuil's part in encouraging this armed Anglo-American intervention (discussed in the following chapter), Couderkerque-Branche was pillaged by the German army. German authorities first offered to purchase the plant (in July 1943), making clear, however, that it would be dismantled and shipped to the Reich. When Lesieur refused this offer, the German military commissioner for Belgium and northern France requisitioned the factory, then had it taken apart and packed off to Germany over the next eleven months. Lesieur resisted what became the systematic looting of 4500 tons of industrial equipment in whatever way it could, but in the end the soap manufactory alone was saved, only to be badly damaged in fighting for the liberation of France in September $1944 .^{61}$

In June 1941, at a time when he was thoroughly engaged in the African project, Lemaigre Dubreuil reviewed in a letter to Marshal Pétain the reasons why he and Lesieur had accepted the government's offer to make the move from Dunkirk to Dakar. In addition to an intense patriotism - that France's defeat was certainly not 'irremediable' - he stated his commitment to overseas France and the global marketplace, which he said was not shared by many metropolitan businessmen. This, he believed, was a loss for France, depriving it of the real benefits economic, political, competitive, technological, and psychological - that came with such foreign involvement. ${ }^{62}$ To be sure, he had just witnessed the French failure in Romania as well as the catastrophic and unexpected fall of France, so the penalties for this lack of aggressive engagement were firmly in his mind. And Lesieur's precarious position on the channel coast and behind German lines surely made the decision to quit Dunkirk for overseas France much easier. Still, in matters economic Lemaigre Dubreuil always took the broader, longer, world view, convinced that in the end both France and Lesieur would profit as would Greater France and the world. This was a patriotism that always accommodated internationalism, and despite the unhappy wartime conditions an optimistic and very positive vision of France's future and its role and mission in the world.

Neither Lemaigre Dubreuil's wartime action in Romania, nor Le Jour-Écho de Paris's belligerent patriotism, nor Georges Lesieur et ses Fils's odyssey in wartime and overseas France spared him or Lesieur the upset of postwar political and economic investigations, which challenged his patriotism and Lesieur's wartime moves, the result no doubt in part of his pre-war presidency of the controversial Taxpayers' Federation, but also of his Vichy contacts, his hopes for France's return to the war, and the nature and political direction of French liberation. 


\title{
3 Defending French Africa
}

\author{
'Laissons parler Crusoë, toujours bien renseigné.' \\ 'Let Crusoe speak. He is always well informed.'
}

General Henri Giraud

\begin{abstract}
Despite France's humiliating defeat, the Franco-German Armistice of June 1940 was unexpectedly lenient. Although it provided for the disarming of French military forces, the internment of almost two million French prisoners-of-war, and the German occupation of the northern three-fifths of France, the armistice allowed a French government - the soon-to-be-established French State (or Vichy regime) - to govern the rest of the country, to retain control of the French fleet, and to continue to exercise sovereignty over the French overseas empire. These terms helped to end the fighting inside France and were decisive in rallying the empire to Vichy where for a time in North Africa (and especially from Algiers) there had been a real desire to struggle on against Germany. For Vichy France, however, the war was over, replaced by the hope that the French State under Marshal Philippe Pétain might negotiate a treaty of peace with Germany that would give France an acceptable place in Hitler's emerging 'new European order.' From the beginning of this French 'postwar' period, therefore, some form of collaboration with Germany was inevitable and even desirable, a political aim of Vichy's leaders, signaled by the well-publicized photo of the handshake between Hitler and Pétain at Montoire-sur-le-Loir in October 1940. This did not mean abject capitulation to Germany, only that cooperation with Germany would be the Vichy order of the day. The extent and form of this collaboration would depend on French interests at the moment (in some cases, for example, Vichy France offered more than Hitler's Germany would accept), the nature of Franco-German relations over time, and the progress of Germany's war in Europe. But Vichy collaboration began with the resigned acceptance of French defeat and of German victory. And the historical memory invoked was that of the Franco-Prussian (or Franco-German) War of 1870-1871 with its unhappy sequence of French military defeat and political collapse followed by the German occupation of northeastern France. Yet since all of this - including the 1871 civil war, which transformed Paris into a terrifying Franco-French combat zone - was prologue to reform in all areas of French national life and a dramatic international recovery,
\end{abstract}


Vichy had no difficulty in representing itself as what it was, the lawful successor of the Third Republic as well as what it wanted to be, the starting point of a French 'new order' and the architect of French renewal. ${ }^{1}$

By signing the armistice Vichy repudiated the English alliance (for the Third Republic had promised not to make a separate peace with Germany) and broke faith with all those Frenchmen who wanted to continue to do battle with Germany. Now England and the 'Free French' under General Charles de Gaulle became the French State's chief adversaries, denouncing and striking out at all of Vichy's attributes of power and prestige. In July 1940, the Royal Navy attacked and sank French ships at anchor at Mers-el-Kébir, the important Algerian naval base, sending the clear but brutal message that it would do whatever was necessary to prevent a Vichy fleet from ever sailing against England. And the following month an Anglo-Gaullist naval force tried to capture the military and naval base at Dakar, jutting invitingly into the Atlantic, as a first step at prying all of French West Africa loose from Vichy authority. This second assault was a calamitous failure, however, humiliating the Gaullists and actually reinforcing Vichy's right to rule. ${ }^{2}$

As an asset for Vichy and thus as a target for its foes, French Africa possessed considerable value. To demonstrate this, in September 1940 Marshal Pétain appointed General Maxime Weygand the government's 'delegate general for French Africa' (with his headquarters at Algiers) and charged him with the overall administrative coordination, military security, and economic well-being of France's African empire. ${ }^{3}$ Not surprisingly, Lemaigre Dubreuil quickly recognized the direct economic benefit to France (as to Lesieur) of factories in Africa. He was also cheered by the Weygand appointment, a signal that French Africa would remain united and French, not divided and parceled out to its German, Italian, or Spanish claimants. The American relationship with French Africa underscored these hopes. From the first the United States recognized the French State as the Third Republic's legitimate successor and the heir to its overseas empire, a policy which for a neutral America that maintained embassies in Berlin, Rome, and Tokyo until the end of 1941 was hardly the risky 'gamble' on Vichy that it was made out to be after the war. ${ }^{4}$ President Franklin D. Roosevelt, who considered French policy his special area of expertise and directed it personally through the White House, appointed Admiral William D. Leahy, his friend and mentor in naval matters, ambassador to Vichy in December 1940. Three months before, however, he had named career foreign service officer Robert D. Murphy (who had more than a decade of experience at the American embassy in Paris) his personal representative in Africa with authority to negotiate with Weygand on economic affairs. This would develop into a combination of American aid and trade, for until France's defeat French Africa had been wrapped up in economic rules and regulations favorable to Frenchmen alone. Now with France down and Britain out, America saw an opportunity for a commercial open door. But perhaps more important to the president, the contact with Weygand and the economic arrangements might also have a favorable impact on the political situation in French Africa. According to William L. Langer, the first historian to interpret America's Vichy policy, Roosevelt hoped that Weygand would develop ' ... an 
organization which would become an important element in combating the Axis, possibly leading to a resumption of hostilities by the French in that area." So despite Roosevelt's strong anti-colonial sentiments and particularly dim view of French colonialism (although on occasion he did claim to see its brighter side), he was willing to extend his policy of support for Marshal Pétain and the Vichy government to the French empire as well.

Lemaigre Dubreuil was an early and valuable contact for Murphy because of his own personal and financial commitment to French Africa, his business and political contacts, and his blunt opinions on politics and economics in France. To a certain extent his views reinforced some of the bases of American policy toward Vichy, particularly the notion that the French collapse reflected serious weaknesses in France itself. To be sure, Lemaigre Dubreuil had little use for most of the political leaders of the Third Republic's final decade, especially the Socialists and Communists who came to the fore with the 1936 Popular Front and with whom he had often sparred while president of the Taxpayers' Federation and as a counselor of the Bank of France. He was not unhappy to see that Republic swept away and replaced with the Pétain regime, although he detected with regret that there was still much of the old Third Republic at Vichy that might corrupt the new order. At the same time he was never a die-hard Vichy loyalist or true believer, even though he could count on a network of highly-placed Vichy confidants for inside information, including Pétain's civilian chef de cabinet Henry du Moulin de Labarthète, Minister of Justice Joseph Barthélemy, professor of law at the University of Paris and honorary member of the Taxpayers' Federation, and Minister of Industrial Production François Lehideux. In addition, Lemaigre Dubreuil always drew on the political instincts and intelligence of Jean Rigault, his loyal second-in-command at the Taxpayers' Federation and long-suffering editor at Le Jour-Écho de Paris, whose personal mix of fierce anti-Germanism and tough, practical monarchism gave a particular slant to the interpretation of the news. In sum, Murphy was surely correct in his assessment of Lemaigre Dubreuil. He was intense, passionate, and patriotic, albeit unconventional in attitudes and action, and as such, certainly not the typical French businessman in wartime. ${ }^{6}$

This, of course, could be an advantage or a liability. For example, Lemaigre Dubreuil always encouraged Murphy to hope for displays of independent acts of anti-German resistance from Weygand whom he deeply admired. In this he turned out to be only partly correct, for Weygand was obedient to Pétain and to his mission of defending Africa 'against everyone.' He had no intention of striking out against Germany and certainly not of making French Africa a military springboard for the 'liberation' of France, a task which as commander-in-chief of French armies in May 1940 he had already ruled out. Even if one of Weygand's notable accomplishments in over a year in North Africa was shepherding the armistice Armée d'Afrique, his American biographer believes with some justification that the armistice itself was the 'culminating moment' of Weygand's life and that in retrospect it was a mistake ever to count on him to violate it in order to bring France back into the war. ${ }^{7}$ In fact, one of Weygand's tasks at Algiers, which he handled aggressively, was to root out 
those 'dissidents' in the North African civil and military administration who were suspected of being less than loyal to Vichy's desire of staying out of the war.

In addition to Weygand, Lemaigre Dubreuil renewed his acquaintance with those officers on and around Weygand's staff with whom he had served in Paris in April-May 1940 when the issue was first Romania, then the survival of France. Chief among them was Captain André Beaufre, head of the Secretariat of National Defense of the Government General of Algeria, who introduced him to the facts and figures of North Africa's military situation and who was eager to renew the fight. In violation of the armistice, Beaufre took it as his special task to procure military supplies for the clandestine rearming of the Army of Africa and over time Beaufre would become well-known to the American foreign service officers in Vichy and Algiers (and later to many in the American intelligence community in North Africa) as a militant and impatient patriot. Through Beaufre, Lemaigre Dubreuil also knew Major Léon Faye of the North African air force's operations and training staff and Colonel Louis Jousse, who headed up the same bureau for the nineteenth Army Corps headquartered at Algiers, both military technicians who quietly planned for North Africa's defense and the time when France would reenter the war. Not surprisingly, two of these three, Beaufre and Faye, correctly suspected of too-close contacts with American agents would ultimately fall victim to Weygand's purge. ${ }^{8}$

When political information was the chief objective of Americans in North Africa, Lemaigre Dubreuil could supply it from a network that stretched from Dunkirk to Dakar and passed through Paris and Vichy. And an occasional American international businessman-turned-soldier showed up in North Africa as an intelligence gatherer, such as Colonel Robert A. Solborg - soon to be the chief of special operations in Spain, Portugal, and North Africa for the U.S. Office of the Coordinator of Information (later the Office of Strategic Services OSS) - whom he knew from before the war. What this meant was that from the end of 1940 Lemaigre Dubreuil kept in close touch with official America in North Africa, creating or reshaping a series of friendships based on shared information and the mutual interest in a French Africa that was no German lackey and that at best was interested in rearming itself and even rejoining the fight against Germany.

Over time Lemaigre Dubreuil became convinced that with the right political and military support from America, French Africa, then perhaps France itself could reenter the war. At first he assumed that this might take place with the active support of Vichy's leaders - Pétain, Laval, and especially Weygand. But this appeared increasingly unlikely in 1941, given Vichy's ongoing commitment to Franco-German collaboration which Lemaigre Dubreuil dismissed as a policy 'linked to a German victory' and, as a result, hated by most Frenchmen. After Germany invaded the Soviet Union in mid-year, however, he hoped that Vichy would take advantage of what he judged to be a 'terrible political mistake' to broker a settlement between England and Germany, thereby winning the peace through diplomacy and restoring France to 'great power' status. ${ }^{9}$ But no diplomatic initiative was forthcoming and collaboration with Germany continued apace. After an attempt on Laval's life in August 1941, Lemaigre Dubreuil commented directly on collaboration to the former 
deputy premier: 'I do not share your collaboration policy, but after getting to know you, as circumstances have led me to do, I cannot help but be impressed by your deep love of France. ${ }^{10}$ Yet without the support of Vichy leaders for a plan of French reentry into the war - and he tried one final time with Weygand on the eve of the general's recall to France in November 1941 - Lemaigre Dubreuil was willing to consider other possibilities, such as the establishment of a North African provisional government, independent of Vichy. ${ }^{11}$

This was precisely what he proposed to Murphy two days before the Japanese bombing of Pearl Harbor and American entry into the world war. Lemaigre Dubreuil openly spoke treason, for he talked of a provisional government 'immediately'recognized by the United States, of American ships to transport French troops and equipment from Dakar to North Africa, of supplies of American arms and ammunition paid for by Bank of France gold stored in Senegal, and of an American expeditionary force of at least three divisions prepared to land in North Africa to support the new government. In addition, he asked the United States to guarantee 'the complete restoration of all the French Empire to France after the termination of hostilities' and, once the landings were successfully completed, to accept French command of all the military forces in French Africa. Finally, as soon as French Africa proclaimed its independence, the United States was urged to send 'at least four warships to Bizerte as a demonstration of its sympathy with the purpose of the French African provisional government to resist [A]xis aggression' for Bizerte was the logical entry point for German and Italian military forces responding to any North African events. The trigger for this somewhat bold and far-reaching proposal - which assumed that there were independence-minded French civilians and soldiers in French Africa, who could carry all this off - was Weygand's 'dismissal' by Vichy under German pressure, which Lemaigre Dubreuil described to Murphy as a 'major catastrophe' that could well lead to the loss of France's African empire to the Axis. ${ }^{12}$

Understandably, Murphy (who for six more days still represented a neutral America in the European war) responded cautiously. He told Lemaigre Dubreuil that at present he could give him no indication of American policy regarding French Africa since it was currently under discussion in Washington. But that America's 'general policy' was 'to assist all those who offer resistance to [A]xis aggression. ${ }^{13}$ Despite this tepid encouragement to his daring plan, Lemaigre Dubreuil continued to expand his contacts with patriotic and wellplaced Frenchmen committed to shielding French Africa from Germany and to working for the restoration of French independence. This was the genesis of the conspiratorial 'Committee of Five' which met at Dar Mahieddine, Lemaigre Dubreuil's villa on the outskirts of Algiers. The first two members were Lemaigre Dubreuil and Jean Rigault, now full-time in Algiers with Lesieur-Afrique after his forced resignation as editor of Le Jour-Écho de Paris in December 1941. The third was career diplomat Jacques Tarbé de SaintHardouin, the former assistant secretary-general of Weygand's Délégation Générale du Gouvernement en Afrique Française, who had worked with Murphy on the Murphy-Weygand Agreement and taken a leave of absence 
from the foreign service on Weygand's departure for France. The final two were Colonel Jean Van Hecke, regional commissioner of the Chantiers de la Jeunesse, Vichy's quasi-military youth organization; and Lieutenant Henri d'Astier de la Vigerie, a staff officer at the Oran division who was a member of a prominent aristocratic family and the middle brother of a trio of anti-German, anti-Vichy militants (he was quickly transferred to Van Hecke's command at Algiers). Diverse in background, in career profile, and in political beliefs (although all were conservative patriots), they agreed on ultimate goals and worked harmoniously in tandem, each in his particular sphere of expertise politics, economics, or matters military. As Rigault later put it, referring specifically to himself and Lemaigre Dubreuil: 'If we had had to define our position at that very moment, we would have said quite openly: we are for anything that leads to the liberation of France. To our way of thinking, that was the only issue. Free from all ties to political parties or groups, acting on our own responsibility and initiative, the only choice we had to make was of the means to achieve under the best conditions possible the first objective that we had set for ourselves: the liberation of French Africa. ${ }^{14}$

What this called for in concrete terms in December 1941 - now that America was in the war - was the preparation of political and military reports for Murphy as a follow-up to the conversation with Lemaigre Dubreuil. Murphy received these documents in early January $1942 .{ }^{15}$ On the political side there were some obvious inducements to persuade the Americans that working with this clandestine group did not contradict U.S. policy toward Vichy - which it clearly did - but rather supplemented it. Only if the French government was unable or unwilling to resist German demands on French Africa, so promised the Committee, would this plan come into play. But there was scant hope for such resistance: 'There is reason to fear,' as one note suggested a bit chillingly, 'that the future of French Africa is dependent in the last analysis on the decision of Germany.' This is precisely what Lemaigre Dubreuil and Rigault thought the Americans needed to hear to get them to commit to action. For their part the conspirators pledged themselves to work to guarantee the cooperation of French Africa's hierarchy of civil and military authorities in any American intervention. And to find a solution to the vexing postWeygand 'high command' problem, for at the moment there was no one in French Africa who had the prestige or the Africa-wide authority necessary to lead such an ambitious enterprise. The search was already under way for partners in this rather elite top-down conspiracy and the hunt was on for that indispensable man on a white horse who could rally Africa's troops and lead them into battle. ${ }^{16}$

Murphy's exchanges with Washington reveal that he had contact with a number of individuals and groups in North Africa who were 'eager to undertake action to resume hostilities against Germany and Italy.' 'Their ideas,' he summed up in early January 1942, 'usually contemplate the temporary separation of French North Africa from metropolitan France, the setting up of a provisional form of government here and, principally, military and economic aid from the United States.' He asked for some guidance from the State Department, particularly since Lemaigre Dubreuil and his friends now insisted on a clear indication of whether or 
not the American government would approve a plan to back an independent North Africa, at least 'in principle.' 'They feel that if they have our agreement in principle,' Murphy explained, 'it will be comparatively easy to build up a powerful organization throughout French Africa, including French West Africa. They say that little progress can be made without such an agreement.' As an aside, Murphy noted that in the past he had always ignored suggestions of this sort since they contradicted America's 'traditional friendly policy toward France', which at the moment meant encouraging the Vichy administration in French Africa to resist the Axis on its own, certainly not working behind its back with independence-minded dissidents. Now he was 'at sea.' Given America's entry into the war and Weygand's forced retirement, he thought it important not to ignore or discourage 'responsible elements' who wanted French Africa to re-join the war. But what should he say to them? Could he tell them more than what he had said in the past, that America wanted to aid 'all those who offer resistance to Axis aggression'? ${ }^{17}$

What Murphy got in reply came slowly, first from the U.S. naval attaché at Tangier, charged with coordinating American military intelligence in Morocco, who told him that the plans of the French for aid to the Allies were of 'great interest' to the State Department and that he, Murphy, was authorized to encourage the French 'to perfect' them. ${ }^{18}$ Then he received a secret State Department letter, dated 5 March 1942, which enclosed the War Department's comments on the military report of the Five which Murphy had sent to Washington at the beginning of January. Although the War Department's Assistant Chief of Staff, General Dwight D. Eisenhower, concluded that no commitments were warranted to anyone at this time, he acknowledged the undoubted American interest in preventing the extension of Axis control in North Africa. If in the coming months, for example, the group could recruit an 'adequate following among civil and military authorities,' their cooperation might turn out to be 'of the highest importance' to American war planning. So Eisenhower recommended that the discussions with the Five continue, 'particularly with a view of determining the capacity and ability of these men to collaborate with us effectively. ${ }^{19}$

This response, even without agreements in the offing, was encouragement enough, for according to the accounts of Lemaigre Dubreuil and Rigault, the work of the Five continued in earnest, especially in revising the military plans to keep up with the fast-changing military situation in the Mediterranean. By March 1942, this meant Allied reverses on the ground in Libya and, worst of all, the loss of Allied naval and air supremacy from Malta to Gibraltar. ${ }^{20}$ Would this be a goad or a deterrent to American action? Counting on the former, the second military report, passed to Murphy in mid-March, went beyond the listing of needed military supplies and material to re-arm the French army in Africa: it envisioned an Allied military intervention in North Africa on a massive scale - 200,000 men and their equipment, including 800 tanks, 120 anti-aircraft batteries, and 500 aircraft - a military force in which French troops, once re-armed and re-organized, were slated to play a starring role. ${ }^{21}$ When Murphy sent this report to Under Secretary of State Sumner Welles, he displayed his own frustration with Washington's long silences: 'May I respectfully urge that you give me a directive in this connection. Do you 
wish me to continue these conversations, or do you wish them dropped? Do you wish the conversations conducted by someone else? ${ }^{22}$

The Five were also impatient, but what is more, they worried about timing, organization, their own safety and morale, and ultimately the reality of Allied cooperation. If the State Department was really serious about the military possibilities of North Africa, Murphy strongly recommended that a qualified regular army officer be sent immediately to make contact with them. Welles explained that he had just received the second military report (sent over a month before by air mail letter) and would telegraph back about it as soon as possible. He would also give consideration 'in due course' to dispatching an army officer to Algiers. ${ }^{23}$ Murphy responded with a desperate account of an 18 April conversation with Lemaigre Dubreuil, who had spoken with Laval for over an hour the day before, Laval's first day back at Vichy as deputy premier. Lemaigre Dubreuil emphasized 'in the strongest possible terms' that the United States had 'nothing to gain' by any sincere effort to cooperate with the Laval government, and as far as French Africa was concerned, should 'urgently contemplate action' along the lines of the second military report. Murphy concluded his dispatch to Welles with his now almost-famous plea:

I cannot urge you too strongly to enable me to give these people some immediate encouragement if this is at all possible. I think this an opportunity we should take at this time. I know it may be unfair to mention it but practically a year has elapsed without to my knowledge the offer to our friends in this area of as much as a cap pistol as practical encouragement. ${ }^{24}$

Since the quiet from Washington continued, the Five sent a joint note to Murphy on 1 May, threatening to cease their efforts to cooperate with America unless they had some positive response on the plan for Allied military intervention within twenty days. If America remained silent or declared itself uninterested, they would turn to the British for help. ${ }^{25}$ 'We have done our best to encourage and hearten these people,' Murphy cabled Welles, surely speaking only for himself but perhaps remembering the small amount of money advanced to the Five by U.S. military intelligence (which the Five had now returned); 'but we cannot indefinitely hold them in a state of suspense. ${ }^{26}$ Then to Murphy's surprise Lemaigre Dubreuil told him that an Allied intelligence agent had just informed them that a 'military expert' would meet with one of the Five on 20 May, the deadline date that the Five had insisted upon. For the moment the crisis with the Five was over, and even without Washington's formal approval of anything, the shaky harmony was restored. ${ }^{27}$

Two striking events now made working with the Five seem more advantageous to Murphy than ever before. The first was the escape of General Henri Giraud from the German prison fortress at Königstein in Saxony. Giraud's Errol Flynn-like exploit, rappelling down castle walls and then, disguised as an Alsatian tourist, walking much of his way to freedom in neutral Switzerland, made an instant celebrity of the six-foot, 63 year-old, five-star general. He was the first authentic French war hero since the armistice, although for a brief moment Laval wanted him to return 
voluntarily to captivity for fear his escape and the patriotic fervor it would generate throughout France might jeopardize Franco-German collaboration. In the end, Giraud came to Vichy, lunched with Marshal Pétain, then retired to a country house near Lyon. To Lemaigre Dubreuil this former commander of the Seventh and Ninth French Armies and previous military governor of Metz seemed the perfect fit for the North African leadership role and, as a bonus, he even looked the part - if Hollywood films were any measure of things - from the oak leaves on his képi to his generous mustache. Murphy, too, was alive to the possibilities of Giraud's sudden emergence on the French scene, asking Governor General Yves Châtel of Algeria, who had shared the table with Giraud at Vichy, if there was any chance that the general would come to North Africa, perhaps as the hoped-for Weygand replacement. Châtel responded with a 'bland smile,' but would not reject the notion out of hand. ${ }^{28}$

The Five immediately designated Lemaigre Dubreuil as their emissary to Giraud and he met with the general on 19 May at Verpillère southwest of Lyon. In contrast to Weygand, Giraud was eager for French re-entry in the war, convinced that Germany was beaten and that combat, not neutrality, was the only hope for the recovery of France's military honor, national pride, and international rank. And he described in some detail to Lemaigre Dubreuil his own grand scheme for an uprising throughout German-occupied Europe in which both the French metropolitan Armistice Army and the African Army would play decisive roles, working together to establish a military bridgehead in southern France as the entryway to the continent for Allied troops to create a second European front. Although startled by the dimensions of Giraud's canvas (on which the general appeared as the central figure of French resistance in both Africa and Europe), Lemaigre Dubreuil found Giraud not unreceptive to the Five's more modest North African plans. He was quite willing to meet with Rigault, who would provide him with additional information and detailed documentation, and enthusiastic about cooperation with an Allied army in French Africa. ${ }^{29}$ Lemaigre Dubreuil returned to Algiers very encouraged and ready to sing the praises of the Five's new 'recruit' to Murphy, now styling himself, perhaps somewhat in jest, as the 'inventor' of Giraud.

The bitter Vichy defense of Madagascar against a British invasion force in early May 1942 was the second occurrence that caused Murphy to believe that his links with the Five were worth keeping. Although ultimately unsuccessful, Vichy's fight allowed the Five to point out that this was precisely what they wanted to avoid in North Africa. Only careful planning well in advance of an Allied intervention, they argued, could produce the political and military cooperation with Alliedfriendly elements in the North African command that would make the costly British strategy of 'ultimata and debarkation without prior accord' unnecessary. As such, the Five could not understand America's 'apparent dilatoriness' in sending a military officer to discuss the basics with them. 'I am very much impressed with the group's earnestness of purpose and their potential usefulness,' Murphy repeated to Washington, adding his well-rehearsed plea: 'I feel that we should provide the military contact now. ${ }^{30}$

With Giraud things moved along swiftly. The general met with Rigault on 30 May 
and 2 June, then a third time later in June with both Rigault and Colonel Van Hecke. He immediately agreed to accept the leadership of the African operations with the understanding, however, that these landings would only be the first phase of his own larger European project. Moreover, he stipulated that he alone would set the date for the North African landings as well as for the landings in southern France - perhaps in the spring of 1943 - and, what is more, he would command both operations from start to finish. Here, of course, the general was not only considering his own age, his rank, and his command and combat experience both in Europe and North Africa, but also trying to make North Africa a quick springboard to the continent in order to avoid the Axis reprisals on France that he knew would follow a French-supported Allied African landing. In addition, Giraud was sensitive to the 'sovereignty issue' and worried about opening the French empire to occupation by an outside, albeit friendly force. Only a Frenchman in secure command of an Allied army on French soil could completely alleviate that concern. In any event, Rigault and Van Hecke were satisfied with what their meetings had accomplished and they assumed that future contacts would resolve all that had been left in limbo. The most immediate and important challenge for the Five was that they were now working with and for Giraud not only as his delegates and emissaries but also as his political mentors, a delicate balance in order to represent (and reshape) the general as the best French (and American) candidate for the leadership of North Africa. In addition, their North African network now expanded to include the senior military officers designated by Giraud as his trusted seconds, including General Antoine-Émile Béthouart, commander of the Casablanca division, and most importantly, General Charles Mast, chief of staff of the nineteenth Army Corps at Algiers (in September 1942, he was promoted to commander of the Algiers division), who would work closely with the Five and act on the spot on Giraud's behalf, since for reasons of security, surprise, and sheer drama the general planned to remain in France until the eve of the landings. ${ }^{31}$

On the American side, despite Murphy's enthusiasm, things were still far from settled and in fact so precarious that in early June OSS Colonel Solborg feared the Five were again on the verge of breaking off with the United States and either giving up or 'going British.' Coming from Lisbon, he appeared unannounced in Casablanca, then made his way to Algiers to tell Murphy that he was on special orders from the War Department with authority to prepare for commitments to the Five. Solborg reviewed the political, economic, financial, and military issues surrounding any Allied landings with the Five, culminating with an agreed-upon transcript of their conversations as well as a memorandum listing items for which the Five wanted answers, including currency matters and Lend-Lease. One item of special note was that the Five accepted the complete responsibility for handling the 'native population.' Finally, the Five and Solborg acknowledged the urgent need for talks between senior French and American staff officers. The significance of this moment for the Five is hard to exaggerate for this was the first time they knew that there might be an Allied landing in North Africa. And one of the leading questions they posed to Washington was whether the American government would recognize the Five as the sole group in North Africa with which it 
would negotiate. Promising to confirm everything as soon as possible, Solborg left for Washington. ${ }^{32}$

The Solborg visit signaled an increased rhythm in the Five's activities. Lemaigre Dubreuil visited Giraud again to inform him of the conversations with Solborg. He touched base as well with Laval at Vichy where he concluded ever more bleakly that the policy of 'obedience' and concessions to Germany continued and that there was still a firm belief in a German victory. ${ }^{33}$ What no one knew at the time was that Solborg had disobeyed OSS orders and traveled to North Africa without permission or instructions. This meant, of course, that the agreements with the Five that he now carried to Washington 'for approval' were unauthorized. But what preoccupied Lemaigre Dubreuil, ignorant of Solborg's insubordination, was that Washington might contact Giraud directly and work with him alone, cutting the Five out of the loop completely. Or drop both Giraud and the Five and deal with the British-backed Gaullists. And because of the partisan divisions among Frenchmen and the confusions and duplicities of wartime, these were no idle frets. First, Lemaigre Dubreuil warned Giraud about having conversations with the Americans without informing the Five: 'it is necessary from a political standpoint to coordinate our action vis-à-vis the Americans, who have the tendency to want to do things their way while we want to do things our way and under conditions - not necessarily the most advantageous for the United States - that we know are necessary for France.' Then, together with General Mast, he presented the following memorandum to Murphy: 'In case a landing of Anglo-Saxon troops took place accompanied by Gaullist elements without prior agreement with those who are effectively heading the resistance against Germany [i.e., Giraud and the Five], French troops would oppose this landing by force. ${ }^{34}$ After eighteen months of working with America, the Five were not about to let their mission be accomplished by other hands.

Finally with no word from Solborg in over a month, the Five complained twice more that they were not being taken seriously by Washington and that this lack of confidence might have important consequences. First, they penned a letter to Solborg, asking Murphy to pass it along. Second, they reminded Murphy face-toface of the risks that they and their confederates were running and that the success of this rather dangerous enterprise depended on speed, discretion, enthusiasm, and cooperation. America, they said, had not been very generous on any of these scores. ${ }^{35}$ Re-reading Murphy's despatches to Washington, it is clear that he agreed with them.

In August, Murphy was called to Washington for meetings on North Africa. He now knew, of course, that Solborg had overstepped his authority by coming to Algiers and had been reprimanded (he was dismissed from the OSS but not from naval intelligence). He also knew that in July the Allied Combined Chiefs of Staff had decided in favor of the North African landings (code name: Operation TORCH) and that American military and intelligence chiefs were ready to consider whatever proposals the Five wanted to make. ${ }^{36}$ So Solborg's June meetings with the Five had not been in vain because the Solborg 'protocols' became the basis of the subsequent talks with Murphy. When Murphy reached Washington, he was briefed on TORCH 
and the details of his own unique appointment as President Roosevelt's 'personal representative' to General Eisenhower, now the designated Allied commander-inchief of the European theater; and, once the landings were completed, as Eisenhower's adviser for civil and political affairs. Murphy was authorized to tell those French nationals whom he considered 'reliable' that America intended to land a sizeable military force in French Africa. In addition, the United States promised to respect French sovereignty in Algeria and to maintain the existing French administration in Morocco and Tunisia because protecting French Africa against an Axis invasion, not freeing it from Vichy, was TORCH's main justification. This was consistent with America's policy toward Vichy, but not with working with Giraud (or the Five), who remained outside of the civil and military chain of command in North Africa. Somehow at the decisive moment Giraud had to appear on the scene as soldier and patriot, loyalist and revolutionary, and rally all North Africa to himself with at most 'the secret and tacit approval' of Marshal Pétain. Finally (and unfortunately), Murphy could give Giraud and the Five only 24 hours notice of the time and place of the landings. ${ }^{37}$

During Murphy's absence, Lemaigre Dubreuil spent six weeks in France, conferring with Giraud on 11 and 22 August and 9 September. The general was still imprecise on how he wanted responsibilities divided between the Five and General Mast, and he further worried Lemaigre Dubreuil by telling him that he had continued to talk and 'negotiate' with American representatives. Giraud insisted again that the Allied landings should be scheduled at the earliest for the spring of 1943 and that the invasion of southern Europe should come quickly on its heels. Lemaigre Dubreuil listened and would report all this back to Murphy, including the Five's anxious pleas for more information of one sort or another on the landings, especially since they were unnerved by constant speculation on 'imminent' Allied action against French Africa as well as of Axis initiatives or counter-measures. This talk had already provoked an announced visit to French Africa in October by Admiral François Darlan, commander-in-chief of French land, sea, and air forces - and considered, like Laval, to be an arch-collaborator with Germany - to inspect French defenses and buck up the confidence of the defenders. In any event, whatever was being planned, the Five needed time to prepare or the Allies, they said, would surely meet 'strong resistance' to the landings everywhere along the Atlantic and the Mediterranean coasts. ${ }^{38}$

To all these worries Murphy replied that he would be back in Algiers during the second week of October and he added to Consul General Felix Cole:

There is substantial reason for them to be reassured. Please endeavor to convey my feeling that there is cause for the greatest optimism and that the group's careful plans and hard work will achieve the hoped for result. ${ }^{39}$

What he meant was first made clear to Lemaigre Dubreuil, who happened to be on the same flight with Murphy from Casablanca to Algiers (on 11 October). As Lemaigre Dubreuil remembered it, Murphy whispered into his ear the 'sensational news' of the ships, the soldiers, the planes, and the equipment. 'Never was a return 
trip to Algiers happier than that one! Two years of ceaseless and painful effort, a long series of hopes mixed with anxiety and discouragement - the habitual fate of any great human enterprise - at last reached the conclusion that we had so desperately worked for. ${ }^{40}$

When Murphy arrived in Algiers, he met immediately (and in secret) with Colonel Jean Chrétien, the head of intelligence for all North Africa at Chrétien's 'urgent request.' Given the rumors of military moves in the western Mediterranean and in consequence the 'extremely fragile' political situation in France, Chrétien (speaking on Darlan's behalf) wanted to know if Darlan came to Algiers and, like Gulliver, pulled the fleet after him, whether America would be willing and able to supply French Africa with 'immediate large scale aid.' Chrétien added that both the military and naval forces in French Africa would 'undoubtedly' obey Darlan's command. To Murphy this was stunning and unexpected news, supplied by a very reliable source and he ranked it of the 'greatest importance.' He urged the War Department to permit him to encourage this cooperation with Darlan, believing that it would be 'reconcilable' with working with Giraud. The caution here was whether Darlan was specifically seeking American support only in case of Axis action against French Africa (and a clue to this might have been that to Murphy's 'surprise' Chrétien asked nothing at all about America's own aggressive intentions) or whether he was ready to jump ship and join the Allies in combat against Germany. ${ }^{41}$ But all this Darlan chat would be valuable prelude to the admiral's sudden appearance in Algiers just before the Allied landings.

When Murphy told Mast the firm news of the landings as well as the possibility of working with Darlan, the general dismissed the admiral as essentially a political animal who could not be trusted and, as such, an unworthy and unreliable partner. He added 'bluntly' that Giraud expected the Allies to deal with him, not Darlan, and that was that. To Murphy's question about the fleet at Toulon and the leadership of the army and navy in French Africa, Mast answered that Giraud, not Darlan, commanded the army's loyalty and that the navy would fall in behind. At this late date, of course, Murphy could not venture toward Darlan alone, especially when Mast and the Five were so hostile to such a move. Mast's overriding concern, however, was not the admiral but whether the Allies were really prepared for a large-scale military operation at this time. When Murphy assured him that they were, he 'insisted' on a meeting between staff officers on 21 October at a spot on the Algerian coast 150 kilometers west of Algiers to which Murphy agreed. And Mast repeated Giraud's wish to unleash the metropolitan Armistice Army before the Axis could move against unoccupied France. Since this could only happen if the TORCH operation included a bridgehead in southern France to funnel supplies to that ill-equipped fighting force, Mast asked Murphy to inquire if this might still be a possibility. Finally, Mast raised the question of the command of TORCH, which Murphy 'dreaded' discussing because of French sensitivity on this point. Mast proposed a 'unified' or overall command under Giraud in which Eisenhower would retain 'complete command' of all American forces. For Mast this was a political but also a practical matter for once Allied troops were on the ground, it was French officers alone who had experience on North African terrain. Murphy 
was forced to refer this issue to Admiral Leahy, now Roosevelt's chief military adviser (since his return to Washington from Vichy in May 1942), with the plaintive yet savvy request: 'Are you able to suggest a happy formula for this delicate point which would leave the command effectively with Eisenhower but permit the French to regard the operation as theirs and require them to lend us their maximum aid?' He added the bait: 'Mast asserts that Giraud's command will give us entry practically without firing a shot. ${ }^{, 42}$

Leahy authorized Murphy to tell Chrétien that if Darlan should decide to resist Axis aggression, America would 'at once' provide large-scale military, material, and economic aid to French Africa. But his response for Mast was unhelpful and perhaps undiplomatic. Leaving the command of TORCH aside (and by implication not a matter for discussion), Leahy simply noted what was desirable but difficult, that the command of the French army and navy 'should be settled by Frenchmen. ${ }^{, 4}$

The Five's elation at the news of the landings was colored by concern over the leadership issue, which Lemaigre Dubreuil later described as both a political and psychological matter. A Frenchman as commander of the Allied armies would free France from its 'obsession' with the defeat and the 'frightful memory' of the armistice, restore its honor and prove that the time of 'martyrdom and humiliation' was over. It would demonstrate as well that France had taken the initiative in its own 'deliverance' and that the Allies were in French Africa as invited guests, not as occupiers, the Allied landings welcomed and not imposed on France. ${ }^{44}$ These were powerful and understandable sentiments, but the leadership of TORCH, despite intense discussions between Murphy and the Five, and Lemaigre Dubreuil's own frenzied shuttle diplomacy between Murphy and Giraud, was never resolved in a clear and satisfactory way before D-Day, 8 November 1942.

The Five now worked together with Murphy (on 15, 18, and 19 October) to draft what would become the Murphy-Giraud Agreement, three letters which confirmed the financial and economic matters that had already been discussed among the Five and Murphy (and Solborg) in June; made an American commitment to the restoration of France and the French empire as of 1939; and wrestled again with the issue of TORCH leadership. In the final version of these documents (dated 2 November) Murphy assured Giraud that the restoration of France 'to full independence, in all the greatness and vastness which it possessed before the war in Europe as well as overseas, is one of the war aims of the United Nations.' And further that it was 'thoroughly understood' that 'French sovereignty will be reestablished as soon as possible throughout all the territory, metropolitan and colonial, over which flew the French flag in 1939.' Finally, that the 'Government of the United States considers the French nation as an ally and will treat it as such.' These were important political commitments and a generous statement of American policy on France that Roosevelt later admitted had gone beyond Murphy's authority. On the sensitive matter of military command the Agreement affirmed the overall American leadership of the TORCH operation, finally accepted by the Five. But regarding the command of North Africa itself about which there were conflicting ideas and different texts, in the end Murphy could only express the U.S. Government's wish to put the military command of French North Africa in the 
hands of the French 'as soon as possible. ${ }^{45}$ In sum, however, the Murphy-Giraud Agreement raised France from the status of a German vassal to the rank of an Allied co-belligerent, a Cinderella-like transformation.

The secret meeting between French and American staff officers at Cherchell, Algeria on the night of 21-22 October did persuade the French that a major military operation would in fact take place and allowed Mast to firm up the American commitment to Giraud. On both sides these were important matters. It was nevertheless true that General Mark W. Clark, who headed the American delegation, left the impression that the landings were at least several weeks away - not just seventeen days - and he stretched American credibility by insisting that TORCH would land a half million men and equipment and 2000 planes, instead of half of that force 108,000 soldiers (with an increase to 250,000 in three weeks) - that would actually disembark. The French officers knew that such a massive force would require more naval transport than the United States could conceivably assemble at this time and field more men than a North African operation could possibly justify. Clark did admit that there would be no simultaneous Allied landings in Provence; that Giraud would have to wait for some unspecified 'appropriate time' after the landings to assume the Allied 'supreme command' in North Africa. However, Mast was neither surprised nor overly distressed by what he heard, only disappointed that Cherchell displayed once again America's less-than-total confidence in its French partners. And this made him increasingly cautious in the days to come. ${ }^{46}$

Lemaigre Dubreuil's part as emissary, interpreter, and advocate in all this was considerable. He visited Giraud in and around Lyon on 24 and 25 October with an account of the Cherchell meeting and the rough drafts of the three letters from Murphy. Giraud was stunned at what he told him about the timing and command structure of the landings and disheartened that they would not include the southern France bridgehead that he considered so vital to French and European liberation. Despite Giraud's concerns, Lemaigre Dubreuil persuaded the general to accept the Agreement provisionally (and so maintain his cooperation with TORCH planners), yet to continue his argument in writing with the American general staff. This was the origin of Giraud's 'Agreement in Principle,' dated 27 October, which after a final meeting with Giraud the following day in Marseille (where the general had moved to situate himself for the leap to North Africa) Lemaigre Dubreuil carried with him on his return to Algiers. In this position paper Giraud accepted all the American proposals for the landings in Algeria and Morocco, 'provided that he himself [acting as Inter-Allied Commander-inChief in North Africa] set the date for the landing,' once informed by the American general staff that all was ready. He also asserted that:

The Inter-Allied Command will begin to function after the landing, that is to say, for each point of debarkation, forty-eight hours after the hour set for the beginning of the initial landing operations of the first convoy. With respect to subsequent operations, the American troops will come under the Inter-Allied Command as soon as they are landed. 
Finally, he argued one more time for the bridgehead in Provence, pointing out that the North African landings would 'immediately bring about the occupation by the Germans of that part of France still free. She may resist, and will, if she is sure of immediate American support. ${ }^{47}$

By encouraging Giraud to write this 'Agreement in Principle' Lemaigre Dubreuil, himself unaware of how firm the TORCH decisions already were or how fast things were moving, may have led Giraud to believe that changes were still possible when they were not. But Murphy, who knew much more than Lemaigre Dubreuil, did the same. To the 2 November final draft of the Agreement, he appended Giraud's paragraph on the Inter-Allied Command with the note that he was communicating this suggestion to the American army's general staff, adding optimistically: 'I am certain that an agreeable solution will be found. ${ }^{48}$ In his memoirs Murphy delicately called these 'assurances couched in ambiguous phrases' that everything could be worked out to Giraud's satisfaction. ${ }^{49}$ Both Murphy's and Lemaigre Dubreuil's purpose, convinced as they both were that Giraud was the key to the success of TORCH, was to ensure the general's cooperation at all costs. Moreover, for Lemaigre Dubreuil sticking by Giraud meant more than Allied military victory because his hopes for North Africa and France (as well perhaps as his own personal political ambitions in a future Giraud government) were tied to the general. ${ }^{50}$

When Lemaigre Dubreuil returned to Algiers on 31 October, he discovered to his horror that the landings were 'imminent' and that a submarine had already been despatched to take Giraud to Gibraltar, Eisenhower's command post. Both he and Mast (who had learned the news two days earlier) protested to Murphy that all this came close to an 'ultimatum' and severely compromised the success of the operation because, as Lemaigre Dubreuil put it, of 'the untimely haste that your Government has shown at the last moment.' He said he was personally faced with a 'terrifying dilemma', which he imagined that Giraud also shared: either to continue working with the Americans, who had shown the North African resistance such little confidence, or to break off that cooperation and assume that the African Army would follow orders and defend Africa against all comers, perhaps even in collaboration with the Germans! At the very least, Mast thought that if America really wanted to keep Giraud as a partner in TORCH, he should be given 'a reasonable number of days' to alert the military resistance in France as to what was about to happen. And Lemaigre Dubreuil, who agreed wholeheartedly with Mast, advised Murphy to cancel the submarine. ${ }^{51}$

In some degree of shock Murphy immediately wired Leahy and recommended a postponement of TORCH, positive that without Giraud and therefore without the cooperation of the French army in North Africa and perhaps even its active opposition, TORCH might fail. If Giraud were given three more weeks to finish things up in France and arrange his departure more carefully, Murphy argued, the benefit to TORCH could be decisive. Leahy would have none of it. He shot back that it was 'utterly impossible' to delay TORCH and that the decision of the President was that the operation would be carried out as planned. Murphy was ordered to do his 'utmost' to get the French to understand the security reasons for American secrecy, that any 'premature disclosure' of plans would not only compromise the operation, 
but French hopes as well. It should be clear to all, Leahy concluded, that TORCH represented the only possibility in the foreseeable future for the 'redemption' of France and involved a 'tremendous' military effort: 'It cannot be delayed. It must be executed. ${ }^{52}$

Murphy conveyed Leahy's message to Mast and the Five and with great misgivings Lemaigre Dubreuil headed back to Marseille where he had no idea what to expect from Giraud. Although greeting him with 'an avalanche of reproaches,' the general had already learned of the 8 November landing date and (once again) adjusted to the new realities. So after leaving the final, clean copies of the MurphyGiraud Agreement with Giraud, Lemaigre Dubreuil returned to Algiers with the general's proclamation to the African Army tucked in his briefcase. ${ }^{53}$ The next night Giraud was picked up by submarine and taken to Gibraltar. Lemaigre Dubreuil's last message to Giraud from Algiers ended with the touching 'We are all with you and close to you in our thoughts' (Nous vivons tous avec vous et près de vous)..$^{54}$

At Gibraltar where he arrived on 7 November, Giraud was further exasperated when Eisenhower claimed complete ignorance of any Inter-Allied Command and indicated that he, Eisenhower, would command the Allied Expeditionary Force until otherwise directed by the Allied Combined Chiefs of Staff. In fact, Eisenhower never intended to turn over the 'supreme command' of Allied troops - even once they were securely on the ground - to Giraud. He had made this plain (and even put it in writing) to Murphy when he reviewed the initial version of the Murphy-Giraud Agreement, but Murphy had done some creative editing to the final text that Giraud reviewed and approved. But in no mood to quarrel with Giraud at this decisive moment for TORCH (and for his own career), Eisenhower did agree to recognize Giraud, as he had been willing to do from the very first, as the 'Commander- in-Chief of all French Forces' and - here perhaps more than was necessary or had ever been promised - as the 'governor' of North Africa. And Eisenhower, who seemed to be impressed by the old general's energy, commitment, and grasp of things, pledged to cooperate with him 'to the fullest possible extent' and in the 'closest collaboration.' Giraud finally agreed to all this - in a sense to be Eisenhower's 'ad latus' - and the two men shook hands, but the dispute had delayed his flight to Algiers. ${ }^{55}$

In Algiers, Lemaigre Dubreuil's activities merged with those of the Five and their civil and military co-conspirators. His own assignment on D-Day was to meet Giraud's plane at the Joinville military airfield at Blida, 25 miles southwest of the city where the general was supposed to land at daybreak on 8 November. Armed with orders signed by Mast (and wearing his military uniform for the first time since June 1940), Captain Lemaigre Dubreuil, together with General Jean Goislard de Monsabert, head of the Blida sector of the nineteenth Military District, arrived at the airfield three hours after midnight with a detachment of soldiers under Monsabert's command.

What happened next illustrates the command conflicts that plagued the landings everywhere. At first the air force officers greeted the announcement of the Allied landings with enthusiasm, but a phone call from Air Force headquarters in 
downtown Algiers changed everything. The airfield commander, Colonel Charles Montrelay, reported that he had been directed to oppose the American 'invasion' by force. Surprised and confused, Monsabert suggested that Mast's orders had not yet been transmitted to the North African air command. But in truth he knew that Vichy's Air Minister, General Jean Bergeret, who outranked Mast, was in Algiers and probably attempting to block the rebel take-over. And both he and Lemaigre Dubreuil realized that in the Five's planning to immobilize the military communication system in Algiers, this secret phone line to the airfield had gone undiscovered. 'From whom did you receive your orders?' the airfield commander queried Monsabert, who replied that they had been hand carried by Lemaigre Dubreuil from Mast.

A second phone call from Air Force headquarters outlined the precise measures that the base commander was to take for the defense of the airfield. After he hung up the phone, he called his officers together, and without saying a word to Monsabert or Lemaigre Dubreuil, they all left the office for the field. Monsabert immediately ordered his soldiers to take up combat positions in the trenches around the field, ready to oppose with force anyone who tried to fire on American planes. Then Lemaigre Dubreuil noticed that the airfield gates were being shut and, fearing capture, he told his driver to move his car outside the fenced perimeter. He sought out the base commander and told him that his true purpose that morning was to wait for the plane bringing Giraud to North Africa which was due to arrive at any moment. 'You certainly won't fire upon General Giraud,' he added. 'My orders,' came the answer, 'are to fire on any aircraft that attempts to land here.' But on reflection he reversed himself and gave the order not to fire on any plane that bore the specific markings of Giraud's aircraft. At once the atmosphere on the airfield became more relaxed, even though Lemaigre Dubreuil sensed that the air force officers probably wanted to jail him and Monsabert until all this was sorted out. But fortunately they hesitated to act.

Time passed. By 7:30 a.m. Lemaigre Dubreuil concluded that Giraud was not going to appear any time soon. Anxious to return to Algiers where he knew the landings were now in progress, he left Monsabert at Blida and drove along the high coast road that led into the city by way of Cape Sidi Ferruch, allowing him to see for himself and for the first time the string of Allied transports that were landing troops along the beaches. And beyond them, the line of battleships and cruisers of the covering group. 'On that pure autumn morning,' he wrote with emotion, 'resplendent with the wonderful light that only Algeria possesses, this reassuring vision remains the most beautiful and pleasant memory that I have of 8 November 1942.' And his thoughts turned back to the time over two years before when on 10 June 1940, having just been made a prisoner of war, he sat on the steps of the Nogent-sur-Seine railway station and watched silently, his heart filled with anger and his spirit fixed on revenge, as two victorious German Panzer units sped by him on the road toward Paris. 'The first act of my revenge had just taken place. ${ }^{56}$

Nevertheless, reaching Algiers was not easy. He encountered military roadblocks manned by troops under orders to oppose the American advance. So even with Mast's orders to the contrary, some senior officers, furious at first learning of 
the landings from a 'rebel' general, refused to break with Vichy's standing orders to defend North Africa against all comers or to step aside and give up command of their troops to someone else. Forced to abandon his car, Lemaigre Dubreuil now found himself in a dangerous fire fight between the soldiers of the two opposing armies. And he sadly realized that for his own safety he had to get out of his uniform as fast as possible. As the vision of a welcomed and waited-for liberation faded into the reality of random combat and unfriendly confrontation, he finally reached Dar Mahieddine, exhausted and shaken. Only after several hours of rest and with the diminished sounds of artillery in the distance, could he hope that this battle for Algiers was over. He concluded somewhat wearily that 'in spite of everything and everyone,' those 'pioneers' of France's liberation - the Five, to be sure, but here he singled out Mast for special praise, for the general had done his best to ensure that the units of the Algiers Division did not impede the American advancehad permitted the Allies to win in North Africa and later to push on to final victory in the European war. They had returned French Africa to the war against Germany and as a member of the Allied coalition. ${ }^{57}$

Lemaigre Dubreuil put the best face on what had become a complicated political and military situation for both the French and the Americans to navigate, so confused in fact that years later it still remains a tough puzzle to piece together. For even if at Algiers with the combined action of the American troops, the French troops under Mast's command, and the civilian resistance, things moved rather quickly and favorably for the Allies on 8 November, there was still serious fighting going on in the city as well as in Oran in western Algeria and in Casablanca, Port Lyautey, and Safi in Morocco. In Morocco, for example, the opposition to the landings came on the orders of General Charles Noguès, a five-star general who was also the resident general of the French protectorate, the top French administrative and foreign affairs officer in the sharifian empire of Sultan Sidi Mohammed Ben Youssef. In 1940, Noguès had directed the entire North African Theatre of Operations from Algiers and after a brief flirtation with rejecting the armistice and fighting on, he led North Africa into the Vichy fold. Weygand aside, Noguès was the most important soldier-administrator in North Africa, although he lacked Weygand's prestige and name recognition. Had Noguès shown the slightest interest in returning North Africa to the war in any of his conversations with Murphy or Lemaigre Dubreuil, he would have been a far better candidate for a leadership role than Giraud. For unlike Giraud he was a soldier (senior in rank to Giraud and part of the North African chain of command), a savvy administrator, and an experienced political negotiator, the only sure recipe for success, as it turned out, in wartime North Africa. But despite Murphy's attempts to draw Noguès into the TORCH conspiracy, he would have none of it and, although he was staunchly anti-Axis and agreeably disposed toward America, he made it clear, following Vichy's standing orders, that any Allied landing would be met with all the firepower he possessed. Giraud's delegate in Morocco, General Béthouart, was understandably reluctant to arrest this senior commander (and iconic figure) even at the moment of truth, but when he finally did place Noguès under house arrest, the general used a secret line to order resistance to the landings which, when he 
was freed from captivity, he continued for three long days. ${ }^{58}$ Lemaigre Dubreuil believed that the Moroccan fighting could have been prevented had the Americans given the Five the time they needed to finish their preparations. And Murphy went even further: 'It is my belief that our French sympathizers could have eliminated nearly all resistance to the invasion if we had given them sufficient advance notice to prepare for our landings. ${ }^{59}$ Perhaps.

Where was Giraud? Despite Lemaigre Dubreuil's messages to Gibraltar pleading that the general come directly to North Africa, Giraud did not arrive in Algiers until 9 November, a full 36 hours late. By then the fighting was in full swing and neither Giraud nor his confederates could end it. General Clark, Eisenhower's man in Algiers, turned to Admiral Darlan, who had come to Algiers 'in greatest secrecy' on 5 November to be with his son, hospitalized with what the doctors thought to be a fatal case of polio. In a brief message to Leahy, Murphy had earlier noted that Darlan's unexpected presence on D-Day might be 'embarrassing. ${ }^{60}$ But now to the Americans he seemed a Godsend. From Gibraltar Eisenhower told the American command in Algiers that '[s]hould Darlan desire to halt all resistance you have the terms of the arrangements and the authority to put them into effect. It must be understood,' he cautioned, 'that the agreement, to be acceptable to the United Nations, must apply to all of French North Africa. ${ }^{61}$ At first Darlan balked and would only order a cease fire for Algiers, fearful that anything more from a high Vichy official might trigger a German occupation of southern France, a catastrophe that he sought to avoid at all costs. And in fact the command adjustments that he made actually increased Noguès's authority, allowing him to continue to fight on against the Americans. But in the end Darlan was pressed by Clark to extend the cease fire to all North Africa. Yet in all these negotiations and jockeying for position, Giraud and his confederates, including Mast, had been kept at arm's length (and some had even been arrested) as the Vichy order in North Africa showed both its teeth and its sticking power. After word of Darlan's cease-fire order and of his assumption of authority in North Africa (in Pétain's name) was relayed to Vichy, Pétain immediately disavowed the admiral and appointed Noguès his 'sole representative' in North Africa. For a moment Darlan, surprised and humiliated, wanted to revoke the cease fire, claiming he now lacked the legitimacy to issue it. This, however, Clark would not permit.

Understandably frustrated by the mess, all Clark wanted was a cease-fire order that would be obeyed and a French command structure with authority to act. He was reluctant to drop Giraud, who had already pressed him to honor the American pledge to name him Commander-in-Chief of all French military forces in North Africa, even though it was clear that Giraud had no power to stop the fighting. What Clark finally proposed was that Giraud and Darlan, who until then had refused to meet with the 'rebel' general, get together in order 'to adjust their claims to power.' (Clark now called them his 'two Kingpins.' $)^{62}$ This was made easier when they both realized to their great dismay that German troops were about to move into southern France. If true, Darlan said he would disregard Pètain's order firing him, being instantly relieved of any moral responsibility to follow Vichy's lead and yet he would willingly exercise power on behalf of the 'captive' marshal. 
And Giraud recognized that in the face of this new calamity for France, now was the time for all Frenchmen to stand together. He withdrew his claim to civil authority in North Africa, the exalted 'governorship' promised by Eisenhower, and, stunning Lemaigre Dubreuil, agreed to work with Darlan in the task he really preferred, as military commander-in-chief of all French forces in North Africa. In many ways this was the ideal solution, putting the right man in the right place for both effective government and prompt military action. To be sure, however, Clark's overall concerns, somewhat lost in these disputes among Frenchmen, still remained ending the fighting and moving Allied soldiers quickly into Tunisia and, equally important, having Darlan direct the French high seas fleet at anchor at Toulon to sail to North Africa or Gibraltar. Neither happened. Tunisia was lost to the Allies because it remained obedient to Vichy's commands, backed up by German military reinforcements. And within three weeks the Toulon fleet scuttled itself on Vichy's standing orders, an act which Clark rightly considered as much an anti-Allied as an anti-Axis sign of defiance. ${ }^{63}$

One final wild card remained - Noguès in Morocco, who, following Darlan's lead, had concluded an armistice with General George S. Patton, Jr., based on little more than a conversation and a handshake. Still wearing Pétain's mantle, he insisted on being a part of the political and military combination being put together in Algiers. And Darlan and the Vichy command clamored for him to be brought to Algiers before anything could be final. For Clark, Noguès only spelled more trouble and stalling. He finally agreed to bring Noguès to Algiers, but confided to Eisenhower that if no agreement could be reached by the French among themselves by sundown on 13 November, he would install Giraud as the 'supreme authority' and arrest all the others. 'It is absolutely essential that we get an established leadership here without further delay. ${ }^{, 64}$ Although at first Noguès was cold to Giraud, refusing to shake his hand and calling him a 'coward' and a 'liar' to his face, he realized that Clark, who said that he would set up an American military government if the three (Darlan, Giraud, and Noguès) did not compose their differences, was unmovable. Even so, Noguès tried to get Giraud to give up the military command of all North Africa for the leadership of only a small volunteer force recruited specifically to fight alongside the Allies with the bulk of the African Army remaining neutral. At first Giraud accepted this, drooping under Darlan's withering verbal assault: 'You are nothing here, nothing but a rebel in the baggage train of a foreign army.' But at the urging of his military staff (and Lemaigre Dubreuil, who exploded in despair: 'We thought we had found an eagle, but clearly it was only a sparrow!'), he later reconsidered. In the end, the admiral and the two generals agreed that Darlan would head the civil government in North Africa, Giraud the armed forces (with the exception of the navy which Darlan also commanded), Noguès Morocco, and Châtel Algeria. In signing this accord Darlan declared that his objective was Germany's defeat and the restoration of France to its former place in the world, the first public pro-Allied statement from anyone in the Vichy command since the Allies had landed almost five days before. Clark was delighted and relieved. And when he explained the agreement to the press, he said that the Frenchmen were 'jubilant' and had 'kissed each other on the cheek.' 'It was quite a family reunion. ${ }^{65}$ 
Perhaps, but not for the extended French family. To be sure, the Gaullists had no part at all in this, but in truth Lemaigre Dubreuil wanted nothing to do with Darlan or the Vichy high command in North Africa and felt that the Americans had abandoned Giraud and with him all the political and economic promises hammered out in the Murphy-Giraud Agreement or made by Eisenhower at Gibraltar. He was angry at Giraud's absence from Algiers on D-Day ('a capital mistake'), shocked at the fighting between French troops and the Allies, and resentful at Darlan's sudden and unexpected emergence as the man of the hour. ${ }^{66}$ During the political negotiations with Darlan and Noguès, Lemaigre Dubreuil had bucked up Giraud, telling him to remember America's commitments and to hold out at the very least for the military command of all North Africa. And once the agreement among Frenchmen was finally made (ratified on 22 November by the Clark-Darlan Agreement), Lemaigre Dubreuil stuck with 'his' general as a solo political adviser without portfolio, while the other four of the Committee of Five accepted posts in the Darlan government-in-the-making. He had defended French Africa according to his lights yet remained bitterly disappointed at the outcome of events, still convinced that Giraud alone - not Darlan - could reap the full benefits of working with the Americans. 


\title{
4 Working for Giraud
}

\author{
'Quelle scie, ce Lemaigre Dubreuil, avec les intérêts de sa firme d'huile. C'est ... le \\ scieur [Lesieur] de service!' \\ 'Lemaigre Dubreuil is such a slippery fellow: always looking to have his palm \\ greased!’
}

General Charles de Gaulle

For the ten months from the time of his 'invention' of Giraud in May 1942, until his resignation from Giraud's staff in March 1943, Lemaigre Dubreuil remained steadfast in his commitment to the general as the political leader of French Africa. In part, this was because he valued the Murphy-Giraud Agreement as the surest instrument for France's re-emergence as an independent and sovereign state on the Allied side. And after two years of relentless work for the liberation of French Africa, Lemaigre Dubreuil believed himself ready to play an important political role, perhaps as Giraud's civilian chief of staff or even as 'prime minister' in a future Giraud government. This made him an adversary of the way things had been sorted out by mid-November 1942, and kept him a moving target for rival Frenchmen long after the Allied landings were over.

In the first days after 8 November, Lemaigre Dubreuil opposed Giraud's acceptance of a post in the Darlan government. He wanted Giraud to head a government of his own or nothing at all. Moreover, he distrusted Darlan, always having favored Laval in the contests for power between the two men at Vichy, believing that the admiral was inspired by individual ambition and a raw quest for personal authority. Added to this was the Vichy baggage and, as Lemaigre Dubreuil put it, Darlan was 'too compromised by his past' to be an effective political leader.' True or not, the 'Darlan deal' was quickly denounced in American and British newspapers as an unsavory bargain with a notorious Nazi sympathizer. It became an explosive political issue in Washington, forcing President Roosevelt to tell the press that the 'present temporary arrangement' in French Africa was only 'a temporary expedient, justified solely by the stress of battle,' even though such an arrangement (with Darlan or any other high ranking Vichy official) had been one desired goal of America's Vichy policy all along and surely was the aim of American planning for the invasion of North Africa. ${ }^{2}$ Roosevelt's words insulted 
the admiral, who now seemed to be working harmoniously with the Allies, and forced General Clark to spend some time explaining to Darlan the politics involved and smoothing ruffled French feathers. But Lemaigre Dubreuil's feathers would not be smoothed, even if anyone had tried. He never adjusted to Darlan in charge.

At first, Lemaigre Dubreuil wished for a second 'coup d'Alger' to replace Darlan with Giraud, then move ahead in cooperation with the Allies. According to Lemaigre Dubreuil, even after Giraud's disappointing performance on 8 November, Giraud alone could rally other dissident Frenchmen to his banner, such as the Gaullists, whereas Darlan was an obstacle to an ever-larger pro-Allied union of Frenchmen. And Giraud would replace the Clark-Darlan Agreement with the Murphy-Giraud Agreement, far more favorable to France as an equal and co-belligerent ally than what Lemaigre Dubreuil rightly believed 'strangely resembled an armistice convention. ${ }^{3}$ Finally and of great significance to Lemaigre Dubreuil, a Giraud government would recognize the Five as the 'initiators' of the move to return North Africa to the Allied side, raising them to prominence from their current position as 'lackluster seconds' used to handle a difficult military situation then discarded. ${ }^{4}$

No one agreed with him. The remaining Four believed that cooperation with Darlan was the only way that any of the promises made by America would be honored. And that refusing to work with Darlan or sabotaging his government would be tantamount to siding against both Giraud and the Americans. So when Darlan met with the Five on 15 November and offered them key government posts, only Lemaigre Dubreuil refused. Tarbé de Saint-Hardouin accepted the Secretariat of Foreign Affairs; Rigault of Political Affairs (including the police and information) with d'Astier de la Vigerie as his assistant to handle the Interior, and Van Hecke, the Youth Secretariat, which for a time was charged with enforcing Algeria's internal security. ${ }^{5}$ Clark was delighted with the appointments, telling Eisenhower that Darlan had accepted 'certain friendly elements' into his government which 'should be favorable to our position.' And Giraud had assured Clark in an earlier conversation that he was working 'in harmony' with Darlan and that the admiral was actively supporting the Allied cause. ${ }^{6}$ Nevertheless, Lemaigre Dubreuil remained skeptical. Despite Giraud's reports and the Four's impressive titles, he thought the Darlan clique was still firmly in control and that in truth the 'newcomers' handled things of only minor importance. ${ }^{7}$

Yet as a proof of his own continuing desire 'to see the new destinies of France triumph,' Lemaigre Dubreuil submitted a blueprint to Darlan for a French Imperial Federation, insisting in his cover letter that he had no other motive than serving French interests. ${ }^{8}$ Three days later the admiral announced the creation of such a federation, designed to represent France 'at the side of the Allies,' assure the 'existence and cohesion' of the different territories of the federation, and prepare for the 'ultimate union' of the federation with metropolitan France. This was Lemaigre Dubreuil's sketch made real. An Imperial Council made up of the residents general and governors general (at the moment only Noguès, Châtel, and Boisson) and the military Commander-in-Chief of French Africa (Giraud) would now advise the admiral on policy matters. ${ }^{9}$ The 
council prevented the institution of a Weygand-style African proconsulate by Darlan (and this may have been Lemaigre Dubreuil's real purpose) even though Darlan retained enormous civil and military power. But it also emphasized the need to continue ever more vigorously the wartime economic and financial coordination of French Africa with, for example, a federal Bank of France, which was Lemaigre Dubreuil's special interest. Nevertheless, it allowed the individual administrators of French Africa wide latitude in internal affairs. Rigault thought it signaled the end of the French empire and a move toward the establishment of dominions 'on the British model. ${ }^{10}$ Moreover, since Darlan had taken the title of High Commissioner (Haut Commissaire), calling his government the High Commissionership in French Africa (Haut Commissariat en Afrique Française), this was another statement of who he wanted to be in the grander scheme of things. As such, it was a solid political step forward for him and for the French interests he represented. ${ }^{11}$

There was no doubt, however, that Vichy ruled. Darlan saw himself as Pétain's 'replacement' in French Africa and he told the imperial hierarchs (and Giraud) in their first meeting together: 'We all acknowledge the marshal to be our leader, but since for all practical purposes he is a prisoner (moralement prisonnier), we will exercise our authority in Africa in his name. This is the guiding principle that we must follow.' Beyond Pétain, however, Darlan intended to hold the United States to its promise to Giraud to restore 'complete sovereignty' to France and its empire as of 1939. Then at war's end, once France was free again, the admiral would retire from public life. As for the Gaullists, Darlan did not think that anyone present wanted to associate with those who had 'fought France' and who refused to recognize Pétain as their leader. Still, de Gaulle and his followers had fought the common enemy 'in their own way,' and if they wanted to join French Africa on the side of the Allies, he "would not turn them away. ${ }^{12}$ Some of this was wishful thinking and some of it difficult to reconcile with the past, yet this was where Darlan stood.

Lemaigre Dubreuil's interest, skill, and ambition in matters governmental and diplomatic pushed him to ask Giraud to let him head up an office to mobilize French resources for the war effort or to appoint him his 'civil adviser,' analogous to Murphy's special position on Eisenhower's staff. Giraud immediately named him the head of an Office of General Studies 'to study and follow' the non-military questions (political and foreign, moral, economic and financial) that affected the conduct of the war. Ironically, his most important responsibility was to act as the liaison between Giraud and Darlan. This was the post - in essence, Giraud's political adviser - that Lemaigre Dubreuil had dreamed of, even if it had been with Giraud in the top spot. ${ }^{13}$

Lemaigre Dubreuil began his work with characteristic energy and commitment. Within the week he had produced a report on the moral and material mobilization of French North Africa, stressing the importance and far-reaching implications of three simple slogans: 'Africa will save France' (L'Afrique sauvera la France), 'Africa is France' (L'Afrique c'est la France), and 'France is back in the war' (La France fait la guerre). But not surprisingly, before two weeks were out he had touched again on the subject that obsessed him yet often wearied and embarrassed 
Giraud: the pressing need to replace Darlan and the High Commissionership. He argued that the High Commissionership had to be replaced since it had lost its raison d'etre. It had been created in the hope of preserving the Vichy connection with Africa, but once Pétain had publicly disavowed Darlan, there was no longer a need to hold on to this myth of continuity. Moreover, the legal and diplomatic status of the High Commissionership in the Allied camp and in the world was ambiguous. Thus, he concluded, it was 'indispensable' that the High Commissionership be transformed into 'a provisional government of France', which would assume all the responsibilities and duties of such a government and seek foreign recognition 'by every means in its power.' And abolishing the High Commissionership - and Darlan with it - would re-open the delicate question of French sovereignty by abrogating the Clark-Darlan Agreement, and perhaps even lead to the revitalization of the Murphy-Giraud Agreement. ${ }^{14}$ Once again Lemaigre Dubreuil showed an understandably passionate commitment to 'his' agreement which, all things considered, Murphy was probably glad had disappeared in the quick march of events. For Murphy-Giraud promised far more to France than Clark-Darlan - even more than Roosevelt had authorized Murphy to pledge - although not the provisional French government that Lemaigre Dubreuil wanted as part and parcel of the package.

With this report also came a detailed proposal for the organization of a provisional government in North Africa. The head of government (or president of the Council of Ministers) was to be the Commander-in-Chief of French military forces as well, so the post was tailor-made for Giraud. Speaking a language that Giraud comprehended, Lemaigre Dubreuil explained that by combining the civil and military functions in the same person, this underscored the 'primacy' of military concerns and ensured a 'perfect coordination' of all efforts toward final victory. But, knowing Giraud's dislike of the non-military side of things, he immediately relieved the general of 'the greater part of the political and administrative responsibilities,' entrusting them to a vice-president of the Council of Ministers, a post apparently designed for himself. Three ministers (of foreign affairs, interior, and economy) would be directly responsible to the Council's vice-president; all four of them became voting members of the Imperial Council of the French Imperial Federation. ${ }^{15}$ These schemes might have had some merit in the best of times, but neither Giraud nor the American leadership could or would consider such far-reaching changes, given the difficulties until then in establishing a stable French African command and the clear American policy against the recognition of any provisional government.

In early December, Giraud assigned Lemaigre Dubreuil to a military mission to the United States headed by General Béthouart. Its purpose was to negotiate for American military supplies and to speed up the delivery of goods and equipment already promised. ${ }^{16}$ This was one of the tasks of the General Studies office because of Lemaigre Dubreuil's interest and expertise in monetary exchange rates and Lend-Lease. But he had no intention of spending all his time buying guns and ammunition. He saw this trip as a chance to sound out the American government on its future plans for North Africa and France and to lobby for his own ideas. All of this, alas, was in complete ignorance of President Roosevelt's imminent trip 
across the Atlantic to meet with Prime Minister Churchill at Casablanca (actually in the residential suburb of Anfa five miles south of the city). The grand military strategy of the war would be the main topic, but during those meetings there would be policy discussions with Giraud and even de Gaulle.

On Christmas Eve, the day that Lemaigre Dubreuil arrived in Washington, Admiral Darlan was assassinated in Algiers. This new jolt to North Africa seemed to spell renewed political quarreling among the French, for Noguès, the least accommodating of the former Vichy hierarchs, was Darlan's designated replacement until a permanent successor could be chosen by the Imperial Council, the 'Grand Electors.' And a majority on the Council favored Noguès as the new High Commissioner. But Eisenhower and Clark were convinced that only Giraud could succeed the admiral, and they pushed for his candidacy. In fact, Clark was so worried about the possible political upset that he did not even want to tell Noguès that Darlan was dead, let alone bring him to Algiers until after Giraud had been installed as High Commissioner. In the end, however, 'on Noguès's proposal' and after considerable American pressure, the Imperial Council duly named Giraud to the admiral's place as High Commissioner in French Africa, as well as Commander-in-Chief of all French land, sea, and air forces (even though Giraud himself preferred Noguès!). ${ }^{17}$ Giraud was finally in the spot that Eisenhower had promised him at Gibraltar and where Lemaigre Dubreuil was so certain that he ought to be. Yet, as Lemaigre Dubreuil later pointed out, Giraud failed - even after urging from Saint-Hardouin and Rigault - to make implementation of the MurphyGiraud Agreement a condition of his acceptance of the High Commissionership. 'Soldiers are sometimes men of great physical courage,' he wrote. 'That was Giraud's case and his life proved it. On the other hand, they often lack political courage and a revolutionary spirit.' 18

Still in Washington, Lemaigre Dubreuil now believed that he had a unique opportunity to plan for the establishment of a provisional government in North Africa and to revive the Murphy-Giraud Agreement. On 27 December, he met with the Chief and Assistant Chief of the State Department's European Affairs Division, Ray Atherton and Samuel Reber. He outlined to them his vision of a North African organization that would have as its primary objective 'to bring all French elements into the war together.' At its top, Giraud, as High Commissioner, would be assisted by a 'consultative group' of three members to advise him on civil and political matters so that he could devote himself primarily 'to the prosecution of the war.' In addition, the Imperial Council as well as a second council composed of delegates from the re-constituted Conseils Généraux of Algeria (the departmental assemblies of the Third Republic, suspended by Vichy) would take on executive functions. This had the whiff of Bonapartism about it, but Giraud was no Napoleon. And the re-invigorated Conseils Généraux were actually meant to signal an authentically democratic inspiration. Finally, Lemaigre Dubreuil stressed that once an organization such as this was established, 'it would expect early recognition by foreign governments as a provisional government,' acting for France and Frenchmen 'until such a time as the French people are free to signify their own choice of a government., 19 
All this was well and good. The plan's main selling point, however, was Lemaigre Dubreuil's conviction that de Gaulle 'would be prepared to associate himself in some way' with such an organization, either as one of Giraud's principal advisers or by appointing delegates to the Imperial Council. He told Atherton and Reber that he was 'empowered' by Giraud 'to deal directly' with de Gaulle on these matters and might even begin to talk with him during de Gaulle's upcoming visit to the United States. (In fact, before leaving Algiers for Washington, Lemaigre Dubreuil had met with one of de Gaulle's emissaries to Giraud, General François d'Astier de la Vigerie, the younger brother of the Committee of Five member. Yet all this was before Darlan's murder and, as a result, nothing had come of that meeting.) More to the point, de Gaulle's own plan to deal with the post-Darlan North African situation was radically different from what Lemaigre Dubreuil proposed. De Gaulle wanted the French National Committee with himself as its chairman to transfer its headquarters from London to Algiers and immediately 'assume the administration of all French territory under Allied control.' In this scheme of things Giraud would be the Committee's designated Commander-in-Chief of all the French armed forces fighting with the Allies. And General Georges Catroux, currently the Gaullist High Commissioner for Syria, would be its 'candidate' to replace Giraud as the High Commissioner in French Africa. In short, what the Imperial Council had given Giraud, de Gaulle would quickly take away. ${ }^{20}$

When Lemaigre Dubreuil met with Secretary of State Cordell Hull on the following day at the State Department, Hull had just issued a press release praising Giraud's selection as High Commissioner. He proclaimed the general 'one of the great military commanders of the world today' and emphasized that his leadership would result 'in greater unification' of all the French 'groups and elements' and go far to assure 'the common victory' through the restoration of French liberty. These were Lemaigre Dubreuil's sentiments translated into English. Now Hull wanted Lemaigre Dubreuil's views on the Gaullist plans for North Africa, so opposed to those expressed by Lemaigre Dubreuil the day before. What Lemaigre Dubreuil could only say in all honesty was that he knew nothing of de Gaulle's plans nor of Giraud's thoughts on French unity since Darlan's assassination. Before leaving Algiers for Washington, however, he certainly knew what Giraud's line of thinking was on this subject. He first told Hull that the general had agreed to head the North African movement to return France and French Africa to the war as 'a French entity' and ally of the United States, 'rather than as the result of American occupation.' He said that Giraud had made a specific agreement with Robert Murphy 'recognizing him as the head of a French Government' that would be provisional until France was free. This was not true. But knowing the mounting American concern over Gaullist demands on North Africa, Lemaigre Dubreuil added that this provisional government should be put in place as soon as possible so as not to weaken Giraud's hand in dealing with de Gaulle and the French National Committee. De Gaulle seemed ready to associate himself 'in some fashion' with Giraud, continued Lemaigre Dubreuil, who as 'supreme head' was already wielding the united political and military command in North Africa. But he concluded that this could never be on 
the basis of the 'entire political control' being exercised by the French National Committee. Rather, de Gaulle should be brought into the organization at first through the Imperial Council, then as an experienced military commander. ${ }^{21}$

Although Hull might have been ignorant of the specifics of the Murphy-Giraud Agreement - and in fact he did not receive copies of the letters that Murphy and Giraud had exchanged until April 1943 - the Secretary acted immediately to reaffirm State Department policy on France. And he asked the White House to issue a policy statement as well. Hull's own 'instruction' to both Eisenhower and Murphy, dated 30 December 1942, indicated the ongoing worry of American policymakers over de Gaulle's efforts 'to obtain complete control over all French territories and activities' and responded as well to Lemaigre Dubreuil's hopes for a provisional government. He stressed the necessity of military cooperation between de Gaulle and Giraud and all other elements of the French resistance to the Axis in order to achieve the defeat of Germany and its allies. And he underscored the need to keep the military effort 'divorced' from political considerations, since the United States would take 'no step' which might 'in the slightest degree' injure the right of the French people to determine their own future and 'to select their own government,' once France has been liberated. As a result, America would 'not accord recognition to any provisional government of France, no matter how constituted and no matter where constituted' until the French people were able to choose such a government by themselves and in complete freedom. ${ }^{22}$

Even though that instruction was never sent and no White House statement was ever issued, this was - and remained - America's policy on France and North Africa. Two days later Roosevelt put it even more bluntly in a cable to Prime Minister Churchill. He said that he felt 'very strongly' that America and Britain had a 'military occupation' in North Africa and that Eisenhower was in 'complete charge of all matters - civil as well as military.' He went on:

We must not let any of our French friends forget this for a moment. By the same token I don't want any of them to think that we are going to recognize any one or any committee or group as representing the French Government or the French Empire. The people of France will settle their own affairs after we have won this war. Until then we can deal with local Frenchmen on a local basis wherever our armies occupy former French territory. And if these local officials won't play ball we will have to replace them. ${ }^{23}$

All this effectively dashed any hopes Lemaigre Dubreuil continued to harbor of turning the Giraud government, which was currently playing ball quite happily with Eisenhower, into a provisional government for North Africa or France. Roosevelt's cable also contradicted British policy, which up until North Africa, had been to turn over all Vichy territory conquered by British arms (or in partnership with Free French forces) to de Gaulle, and not to consider these lands, at least in civil affairs, under British military occupation. Surely the people of France alone, argued the Foreign Office, had to determine their own form of government. But 'some French authority, in effect if not in name a provisional government,' had 
to govern in France and its empire until that permanent government could be established. And during this time 'it must be de Gaulle.' As the U.S. Chargé in the United Kingdom explained it: 'British prestige requires that "the one Frenchman who stuck by us in the dark days of 1940" must be installed in France when the day of liberation comes, however fleeting his tenure may be and whatever the consequences for the people of France. ${ }^{24}$ So the most that Lemaigre Dubreuil could hope for in the face of Britain's commitment to de Gaulle was that America would continue to back Giraud for the top spot in North Africa.

Lemaigre Dubreuil had his work cut out for him. He suggested to Hull in another meeting during the second week of January that the best way for American policy to triumph in North Africa was to acknowledge that Giraud (and those Frenchmen who had worked closely with him) had actually negotiated the American military intervention through the Murphy-Giraud Agreement. So, despite Roosevelt's wishful thinking, North Africa was not really occupied territory, but an American ally in full possession of its sovereignty. Recognition of this fact, so Lemaigre Dubreuil noted in his own briefing memorandum, was at 'the very center' of the negotiations at Washington. ${ }^{25}$ From this should follow the quick supply of American military equipment to French troops, the announcement of a favorable currency rate of exchange between the franc and the dollar, and some form of North African diplomatic representation in the United States. And if Giraud could not be recognized by America as the head of a provisional North African government, he might at least be regarded as the 'trustee' (in the French text, le dépositaire) for French interests until the end of the war. All this would cut the political ground from under the Gaullists (and the British, too!), ending the French leadership controversy and, best of all, returning the primary focus to the military campaign against the Axis. Moreover - and, as always, this was very important to Lemaigre Dubreuil - this would make it clear that there had been Frenchmen other than de Gaulle quietly at work since 1940 to return France to the war on the Allied side. In the end with the help of America they had prevailed. Hull promised to give all these matters his 'prompt attention' and to discuss them with the president. ${ }^{26}$

Two days later Lemaigre Dubreuil met one final time with Atherton and Reber at the State Department. They assured him that Giraud would immediately be granted the civil representation in the United States that he wanted. Building on his previous conversations, Lemaigre Dubreuil then outlined a proposed political scenario that he hoped would meet with American approval. On his return to Algiers, he would have Giraud issue a declaration stating that since no government now existed in France, the general would act as a trustee for French interests until the time when Frenchmen could choose their own government. Roosevelt would respond in a separate declaration by recognizing Giraud as an ally 'in full possession of sovereignty,' entrusted with the military defense and protection of French interests, a trusteeship that would end once France was free again. It was agreed that Lemaigre Dubreuil should first discuss all this with Eisenhower in Algiers and that only after reviewing Eisenhower's recommendations would the State Department comment further on the plan. ${ }^{27}$ 
By now, of course, Roosevelt was en route to Casablanca, but no one in the State Department had bothered to tell Lemaigre Dubreuil. At his farewell meeting with Hull on 16 January, two days after the Casablanca summit had begun, the most the Secretary would reveal was the promise of a 'surprise' once Lemaigre Dubreuil returned to North Africa plus the quiet prompting that he might want to get back there as soon as possible. ${ }^{28}$ Nothing more. Why keep him in the dark? Was it to deny Giraud the benefit of this dogged adviser whose requests always centered on raising the political and military status of North Africa to that of a sovereign state and an Allied co-belligerent? Was it to allow Roosevelt to make French policy at Casablanca unencumbered by the promises made by his own personal representative in North Africa? ${ }^{29}$ In any event, Lemaigre Dubreuil felt betrayed by Washington when he arrived in Algiers only to discover that Giraud was at that very moment at Casablanca discussing the future of France and North Africa with Roosevelt.

At Casablanca things moved quickly. Three days into the conference Roosevelt persuaded Churchill to bring de Gaulle to Anfa, convinced that French unity might be hurried along by a face-to-face meeting between de Gaulle and Giraud. For his part Roosevelt (together with Murphy and General Clark) met alone with Giraud on the afternoon of 17 January. Although the general gave him 'the impression of a man who wants to fight and has no great interest in civil affairs,' the two men did discuss the critical matters of French sovereignty and union, especially the formation of a Committee for the Liberation of France, embracing both Giraud and de Gaulle. As ever, Giraud welcomed the possibility of any all-French military cooperation, as well as the introduction of those territories under Gaullist control (such as Madagascar and Réunion) 'into the African picture,' implying that they would fall under his political authority. Roosevelt thought this might be going a bit too far, and too fast for de Gaulle. And perhaps for the president as well, for he also suggested that with the establishment of a French liberation committee, the French Imperial Council (with its pretensions to sovereignty) ought to be disbanded. ${ }^{30}$

Two days later Giraud met again with the president and his men. As preparation for this meeting, Harry Hopkins, the president's closest adviser, spoke at length with Prince André Poniatowski, one of Giraud's military aides (an expert, among other things, on the design and construction of modern tanks) on the range of topics that would be discussed. According to Hopkins, Poniatowski made it clear that Giraud wanted to be the 'top dog' in any new French organization with de Gaulle as the 'No. 2 man.' Then, reported Hopkins, Poniatowski added 'some other vague business' about French sovereignty. Hopkins told Poniatowski that he thought Roosevelt wanted Giraud to 'land on top' in any combination with de Gaulle, but that on the sovereignty issue 'he would recognize no one, not even Giraud, as representing France. ${ }^{31}$ As a result, when Giraud met with the president, he left sovereignty to the last, letting Roosevelt go on at length about the formation of a Committee for the Liberation of France. The president held that it should consist of the two generals - Giraud, the 'senior member,' and de Gaulle as 'Chief of Staff, or Inspector-General, or some such convenient title' - and a civilian, a senior civil administrator who would relieve Giraud of many, if not most, of his administrative duties. Giraud approved wholeheartedly of this proposal which fit in with his own 
notions and especially his guiding principle that nothing ought to interrupt the conduct of the war. Most importantly, Roosevelt promised Giraud new American military equipment for the North African French army as well as a favorable currency exchange rate to make future military purchases in the United States easier, promises eagerly sought by the general and designed to buck him up both on the military battlefield and in the political tug-of-war with de Gaulle. ${ }^{32}$

Based on that one-hour meeting, Hopkins gained a 'very favorable impression' of Giraud, who spoke modestly but with confidence, and particularly so when he stressed 'with great vigor' his determination to remain the political and military leader of French Africa. In fact, only on the sovereignty issue was Giraud disappointed, for, as Hopkins predicted, Roosevelt was 'adamant' that for the time being the general must act only as a 'representative in North Africa,' and not 'in any sense' speak for France. Hopkins called it 'a very satisfactory conference' and was sure that Giraud and Roosevelt had 'mutual confidence' in each other. ${ }^{33}$ And in truth, Giraud handled himself very well, strengthening his personal ties with Roosevelt and advancing his own and French interests as far as he could.

What of Lemaigre Dubreuil? He arrived in Casablanca on 21 January, furious that Giraud had gone to the conference without him. He speculated that Murphy was behind some of this, wanting to keep Giraud as isolated and politically ignorant as possible. 'We are heading for a disaster,' he wrote to Jean Monnet, the French member of the Combined Munitions Assignment Board in Washington. 'Everything I had set up will without doubt collapse. The French will lose, the Americans too. Only the Germans will win. ${ }^{34}$ Once at Anfa, however, even Giraud kept him at arm's length, refusing to bring him to the conference sessions, certain that he would merely upset the Americans with his single-minded insistence on a revived Murphy-Giraud Agreement. He did agree, at Lemaigre Dubreuil's insistence, to take a hastily-drafted political memorandum to his final session with Roosevelt on 24 January. When Giraud returned with this 'Anfa Memorandum' marked 'Approved' in the president's bold script, Lemaigre Dubreuil burst into tears of emotion. ${ }^{35}$ The memorandum contained everything (and more) that he had struggled to win for Giraud and North Africa after the unexpected outcome of the Allied landings. It began by noting that the Allied intervention had been 'at the demand' (sur la demande) of those Frenchmen who 'since 1940' (dès 1940) had sought to take up arms against Germany, calling it 'the first act of liberation of an oppressed nation' (le premier acte de libération d'une nation opprimée) by the United Nations. Then it referred directly to the letters exchanged between Murphy and Giraud before the landings and decreed: 'They remain in force' (Elles demeurent en vigueur). Finally, it stated that until Frenchmen were free to choose their own government, the United States and Great Britain recognized 'in the Commanderin-Chief, with his headquarters in Algiers, the right and duty of preserving all French interests under the military, economic, financial and moral plan' (au commandant en chef français, siègeant à Alger, le droit et le devoir de préserver sur le plan militaire, économique, financier et moral, tous les intérêts français). ${ }^{36}$ This was, of course, the trusteeship that Lemaigre Dubreuil had floated in Washington and which Giraud then described as such in a telegram to Béthouart, still in the United 
States with the permanent French military mission: 'In the absence of a French government, I have been recognized as the trustee of all French interests. ${ }^{, 37}$ It is not difficult to understand Lemaigre Dubreuil's intense feelings about the Anfa Memorandum. He later wrote that at this moment the United Nations recognized French sovereignty over the Metropole and the overseas territories for the very first time, and made it clear that France would join the United Nations for the rest of the war, for the peace, and 'for all the future problems resulting from both. ${ }^{38}$ For Lemaigre Dubreuil France was finally back again as a great power and on the Allied side.

Forever after, Lemaigre Dubreuil insisted that at Anfa he had been working for France, not just Giraud, and, as proof, he cited the phrase in the memorandum, which referred to an unnamed French 'Commander-in-Chief, with his headquarters in Algiers.' But the transcripts of the Washington conversations indicate otherwise, for in them he argued exclusively for Giraud and against de Gaulle. This might merely have been good politics, as Lemaigre Dubreuil argued it was, for no one in the State Department wanted to hear of French unity captained by anyone but Giraud, and certainly not de Gaulle. ${ }^{39}$ But beyond differing interpretations of the record and Lemaigre Dubreuil's special pleading, de Gaulle was sure that Lemaigre Dubreuil was acting against him. His meeting with Giraud on 23 January had gone badly. Giraud refused to cede the leadership post to de Gaulle, who had failed to convince him of the symbolic and unifying value of the Free France mystique. And Giraud saw no reason to agree to purge his administration or the Imperial Council of those former Vichy officials who had finally rallied around him (and in fact had named him High Commissioner of French Africa). Thus, when de Gaulle learned of the Anfa Memorandum, signed while he was en route back to London, he could not help but see it as part of an ongoing conspiracy by Giraud, Lemaigre Dubreuil, and the Americans to construct a counter-organization for French unity and liberation without him (or with him but only in a secondary role). ${ }^{40}$

Churchill was also alarmed at the Anfa Memorandum because Roosevelt had signed on behalf of the United States and Great Britain, implicitly transferring British support from de Gaulle to Giraud by recognizing Giraud as the sole wartime trustee for 'all French interests.' This dramatically altered British policy (in a document that Churchill had never seen) and went farther with Giraud than Churchill had ever been willing to go with de Gaulle. The Prime Minister did not want to offend Roosevelt by objecting too strenuously to the memorandum (even though the President, somewhat embarrassed, later said he had signed it over a drink) nor did he wish to abandon de Gaulle or junk British policy on France. So important was this matter that Churchill returned to Algiers on 5 February (en route to London from Ankara) to discuss his dilemma with Murphy. Murphy understood; he had already telegraphed Washington that he believed that Roosevelt only meant to designate Giraud as the trustee for those French interests in French Africa presently under the general's authority, nothing more. And he was correct. So together Churchill and Murphy revised the memorandum and - without ever discussing the issue with Lemaigre Dubreuil - Giraud approved the revisions. ${ }^{41}$

The most sweeping alteration to the memorandum was the elimination of the 
sentence 'They remain in force' which referred to the Murphy-Giraud letters. So it was appropriate, while unfortunate, that Murphy did the altering and Giraud approved the revised text. The phrase 'preserving all French interests' became 'acting as a trustee for French interests, military, economic, and financial in French territories, which are associated or which hereafter become associated with the movement of liberation now established in French North and West Africa.' This left de Gaulle in control of all those French territories which had rallied to him since 1940 until such time that he wanted to join them to North and West Africa. ${ }^{42}$ With these significant changes Churchill could comfortably accept what was left. There was not much.

Since Casablanca Lemaigre Dubreuil had been serving once more as Giraud's Inter-Allied Affairs delegate as well as helping to reorganize the government (especially the Secretariat-General of Foreign Affairs) in light of the Anfa Memorandum. The High Commissionership disappeared, transformed into the French Military and Civil Command (Commandement en chef français civil et militaire) in Algiers with Giraud as its Commander-in-Chief. The Imperial Council reemerged as the War Council (Comité de guerre) with its policy-making authority and membership intact, but with the single addition of Marcel Peyrouton, Vichy's former Minister of the Interior (until February 1941) and Ambassador to Argentina, who replaced Châtel as Governor-General of Algeria. Prosecuting the war was the council's main concern, but this required a coordinated politicalmilitary effort throughout French Africa, including special attention, so read the council's transcript, to reinforcing the ties between the Algiers government and the populations of both metropolitan and overseas France. General Bergeret, Darlan's former Assistant High Commissioner for administrative affairs, became the Secretary-General of the civil side of things, still retaining his War Council seat. And a High Economic Council (Haut Conseil Économique) was created to handle the myriad financial and economic issues of independent wartime French Africa, including the need for a viable federal financial institution (caisse fédérale) or an overseas Bank of France. Ending the High Commissionership once and for all and setting up an economic council (with the possibility of an overseas bank) were just two of Lemaigre Dubreuil's initiatives that took shape. ${ }^{43}$

Despite all this Anfa-related activity, Giraud failed to inform Lemaigre Dubreuil of the revised Anfa Memorandum (or even that Churchill had been in Algiers!) until after the deed was done. Lemaigre Dubreuil was understandably cold with grief. What Murphy and Churchill achieved at Algiers, he told the general, 'destroy in my opinion (and as far as I can tell after a quick reading) all that I did at Washington and part of what you obtained at Anfa.' He added: 'I utter this last cry of alarm for you to protect France's position, for it is quite evident that if I am kept outside of everything, I cannot accept responsibility for the official defense of French interests. ${ }^{44}$ The handwriting had been on the wall for some time. He had never won Giraud's confidence in matters political and the proof was the quiet demise of the Anfa Memorandum, although, given American policy on France, it is unlikely that he could have kept the original memorandum alive. He tried one final time. In a conversation with Murphy on 7 February and in a 
desperate exchange of letters between Giraud and Murphy (10 and 19 February), he asked for clarification on precisely how President Roosevelt understood Giraud's trusteeship of French interests in the United States or in countries where the United States had significant influence, such as Central and South America. ${ }^{45}$ But it was too late. Just as he feared, Giraud no longer represented the 'totality' of French interests and, until a union with de Gaulle was achieved later on, no single voice would be able to speak for France..$^{46}$ Long after, he asserted that without the promises contained in the Anfa Memorandum France was 'absent' from all the wartime summits - Teheran, Cairo, Yalta, and Potsdam. And he was certainly correct. $^{47}$

The desired union among Frenchmen continued to occupy center stage. When Lemaigre Dubreuil, still in his capacity as Inter-Allied Affairs delegate (but now with Giraud's written pledge to keep him informed), spoke with General Georges Catroux, de Gaulle's emissary to the Giraud camp, the general acknowledged that 'the most difficult point' of any union would be to settle on a leader. In de Gaulle's favor, argued Catroux, was that he had rejected the armistice from the beginning and never stopped fighting on the side of the Allies. It was this 'invaluable capital' that de Gaulle could bring to any postwar peace table. On the other hand, it was Giraud, responded Lemaigre Dubreuil, who had returned to the lists that vital part of the French empire which, from a strategic point of view, was destined to play 'a decisive role' in the war's outcome. Catroux did not dispute this. In fact, it was this 'equality of service' to France that made the choice of a leader so agonizing. Beyond de Gaulle-Giraud, Catroux believed that any really determined war effort from Algiers demanded a new team, not Vichy's old guard still in place everywhere in French Africa. And the repeal of Vichy's legislation as well, laws long considered null and void by the French National Committee in London. To sum up, public opinion needed a 'psychological shock' and this could only come about with new men and new deeds. ${ }^{48}$

Lemaigre Dubreuil agreed with much of this and he reported to Giraud that Gaullism was making 'considerable progress' in French Africa because of the 'deep disappointment' that Vichy was still in charge - 'the maintenance in place or the appointment of men hostile to any new policy and who are infected with Vichyite attitudes' - and that Giraud hesitated (or even refused) to choose between the past and the future. All this despite Lemaigre Dubreuil's constant drumbeat of alarm and opposition. 'Many things and perhaps even some of my actions,' he told the general, 'may have caused you to question my loyalty to you.' 'But despite cruel disappointments, my sentiments toward you have never changed. My faith in your magnificent spirit, that of a true soldier, has remained absolute. But my commitment to bring my country out of the quagmire (son impasse) it is in continues to animate me just as it did on the day (10 June 1940) that I made it.' This was close to being a letter of hail and farewell, although Lemaigre Dubreuil still pledged his complete and affectionate cooperation for what he hoped would be the 'second act' of the drama that had begun on 8 November $1942 .{ }^{49}$

America had its own plan to strengthen Giraud and democratize his regime. And one of the instruments for this change would be Jean Monnet whom Harry Hopkins 
had seen in action on the Combined Munitions Assignment Board. Hopkins admired Monnet's intelligence, energy, and fair-mindedness - a French patriot with no political axe to grind - and he convinced Roosevelt to send him to North Africa, essentially as a presidential envoy, to persuade Giraud to make political changes in his administration (although officially his task was to monitor the progress of American military and economic supplies to French Africa).$^{50}$ Monnet met with great success. On 14 March, Giraud delivered his first major political address, which included the spectacular announcement that all Vichy legislation was henceforth invalid in North Africa and the equally stunning pledge of a speedy return to republican government. The text was by Monnet. But Giraud was not really a ventriloquist's dummy. Days before, Murphy had reported to Washington that after a conversation with Giraud he was convinced more than ever of the general's desire 'to make a clean break with undesirable Vichy ideas and policies' and of his commitment as well to top-level personnel changes. ${ }^{51}$ But only America's emissaries, not Lemaigre Dubreuil had the necessary clout to bring all of this about. The immediate consequence of Giraud's message was a flurry of resignations, including those of SecretaryGeneral Jean Bergeret and Political Affairs director Jean Rigault, who explained his abrupt departure in a short note to Giraud: 'In yesterday's speech you said that all power comes from the people. Since mine did not, I have the honor to send you my resignation. ${ }^{, 52}$ Lemaigre Dubreuil remained at his post for eleven more days, then resigned on 26 March because he had grown weary of being bypassed when advice was needed or decisions were made. Years later he recalled quite accurately that the 14 March speech had been prepared 'in great secrecy' by Monnet, Colonel François de Linarès, the trusted chief of Giraud's military staff, and Giraud himself. He had neither been informed of its contents nor asked for his opinion. ${ }^{53} \mathrm{It}$ was, alas, the Anfa Memorandum all over again. Not surprisingly, Lemaigre Dubreuil's successor as Giraud's delegate for Inter-Allied Affairs was Jean Monnet.

This was the end of Lemaigre Dubreuil's short and traumatic career in North Africa. He retreated to his villa in Algiers to write his account of the preparations for the Allied landings. But occasionally he dashed off a letter to Giraud, commenting on some of the general's decisions and arguing ceaselessly for the creation of a provisional government (or a trusteeship council), once a union with the Gaullists had been achieved, as absolutely 'necessary' to permit France to take its place as a full-fledged partner among the United Nations, no longer dependent on the 'good or bad will' of the Allies. ${ }^{54}$ In spring 1943, Giraud and de Gaulle did agree on a formula for unity, which centered on the creation of a French Committee of National Liberation in Algiers, co-chaired by both generals. But the transformation of this Committee into a provisional government - an action ever opposed by the United States and by Giraud as well - did not come until April-May 1944, long after De Gaulle had gained firm political control of the Committee, excluding Giraud and had even broken the general's power over the army by insisting that the military command be separate from and subordinate to the civil authority of the Committee. By this time America had abandoned its one-time champion on a white horse. ${ }^{55}$ 
Witnessing all of this up close, Lemaigre Dubreuil became increasingly alarmed at the Gaullist domination of the National Liberation Committee. First, he knew that the top-level personnel changes - in particular, the resignations of Governors General Boisson and Peyrouton and Resident General Noguès - that came just before or soon after the formation of the Committee were Gaullist inspired or required. Then, in September 1943, the Committee's Gaullist majority created a 'purge commission' charged with examining the actions of all former Vichy officials, who had encouraged enemy activities or had worked against the Allies or the French resistance. Although Lemaigre Dubreuil fit none of these categories, he recognized that the political winds had shifted against him and he was sufficiently fearful for his own safety to leave Algiers for Casablanca in May 1944 , then to cross the border into Spanish Morocco and finally to Spain.

Once in Madrid, he wrote de Gaulle directly, angrily accusing him of planning to put liberated France in the hands of a partisan provisional government that would foster disorder, violence, and hatred, shaking the foundations of the entire social order. ${ }^{56}$ His letter received no reply. Then a week after the Allied landings in Normandy on 6 June 1944, he contacted Secretary of State Hull repeating these same concerns and emphasizing de Gaulle's plans 'to seize power in France.' He suggested that he might be of help in stopping this, if he were backed by the United States, which surely could not want a Gaullist take-over. 'Our goal,' he insisted, 'is to maintain order and at all costs to avoid civil war.' He portrayed himself as a partisan of America's policy of letting France decide its own political future at war's end and as a willing partner of the Allies. He said that he wanted only to unite Frenchmen against the common enemy 'of today and tomorrow,' rather than dividing them to satisfy 'personal ambitions,' a familiar Giraudist theme played one more time. ${ }^{57}$ These messages to Hull went unanswered.

At the same time Lemaigre Dubreuil also met with Vichy's ambassador to Spain, François Piétri, who long before the Normandy landings had been urging Laval to make contact with American representatives to negotiate France's future. Before Normandy Laval would have none of it, but after the landings both he and German Ambassador in Paris Otto Abetz sent envoys to Madrid to speak with any American intermediaries that Piétri could find. From the way Lemaigre Dubreuil talked, he gave the impression (at least to the Germans) that he was in touch with 'influential American political personalities.' He suggested that the Americans might support 'a legal and democratically-based coalition government which included the Vichy group,' headed by the leaders of a reconvened parliament (for example, President of the Chamber of Deputies Édouard Herriot and President of the Senate Jules Jeanneney) and perhaps even Pétain himself. ${ }^{58}$ All this was presented in a way to emphasize America's fear of a Gaullist dictatorship and determination - at all costs - to block the general's grip on power. This tallied perfectly with the mounting concerns of both Laval and the Germans and their desire for multiple channels of information and negotiation with the Allies. Yet, despite what he did or did not say, Lemaigre Dubreuil was never an American representative. The Germans ultimately sensed this and ended all contacts with him in mid-July. And Laval made no effort at all to work through Lemaigre 
Dubreuil, even though he did try to reconvene parliament in August in a last, futile attempt to save himself and Vichy.

In August 1944, Lemaigre Dubreuil returned to France, then Paris. As persona non grata with the Gaullists, he was more than ever worried about Gaullist rule, especially the wholesale branding of all those who had served Pétain - regardless of their intentions or their accomplishments - as 'the traitors of Vichy.' For the two years that he had shuttled back and forth from France to North Africa on Lesieur business and undercover missions, he had found sympathy and support from many at Vichy. He judged this indiscriminate purge irresponsible and extreme. As much as anything else, he feared the political consequences of the active alliance between the communist and non-communist resistance, which he figured put de Gaulle in Stalin's hip pocket. Thus, for personal and national reasons he argued for immediately disarming all the resistance groups, ending 'terrorist measures,' and re-establishing freedom of the press (in part because he wanted to revive his own Le Jour-Écho de Paris). ${ }^{59}$ It was later bruited about in unfriendly newspaper stories that during this time (the fall of 1944) he had been in cahoots with steel magnate François de Wendel, Bank of France Governor Pierre Fournier, Radical-Socialist politician Paul Bastid, and far-right republican leader Louis Marin to form a conservative political coalition and make a bid for power ${ }^{60}$ But there is no evidence for any of this.

Lemaigre Dubreuil's own worries stocked the nightmares of many Frenchmen, but the difference was that he actively sought to do something to exorcize them. For his pains he first incurred the wrath of the provisional government in Algiers which, based on his contacts of one sort or another with 'enemy agents,' added his name to the list of those whose property was liable for confiscation. In due course Lesieur property in Morocco (but apparently not in Algeria or Senegal) was turned over to a Lesieur competitor, the Société des Huileries Marocaines, until the courts could sort out and settle the matter. Lemaigre Dubreuil himself was arrested in Paris on 29 December 1944, charged with treason, 'desertion abroad in time of war,' and 'irregular border crossings,' and imprisoned at Fresnes. In May 1945, the First Military Tribunal of Paris acquitted him of all these charges for lack of evidence; the following month the confiscated property of Lesieur-Afrique Casablanca was returned by order of the Minister of Finance. ${ }^{61}$ Although this officially ended Lemaigre Dubreuil's quarrel with the government and its legal system, it did not compensate for the duress of four months in prison nor for distorting his war record or disparaging his name. He spent his first postwar years putting his papers in order, then setting his North African record straight through his own writings (including a raft of letters-to-the-editors) and even financing a ' $\mathrm{B}$ ' movie, Le Grand Rendez-vous (Films Vendôme, 1950). In addition, he immersed himself in expensive and time-consuming litigation against the flood of articles, books, and memoirs on wartime North Africa that he considered uninformed, inaccurate or defamatory. ${ }^{62}$ Defending his reputation turned out to be a challenging and often frustrating task, but unlike the other members of the Five - and even Giraud himself - he was unwilling to slip quietly into History's dustbin. And in truth, with lawyers' briefs and court decisions, he was providing ample documentation for 
future historians. As he told diplomat-historian Albert Kammerer, 'I do not believe that if History is objectively recounted, it can ever decide against me. ${ }^{63}$

What was Lemaigre Dubreuil's own verdict on working for Giraud, the man whom he had championed as the chief of the North African resistance, as the military commander of French forces engaged with the Allies in the combat against Germany, as the civil and political leader of French Africa and the trustee for all French interests worldwide, and as the head of the continuing crusade for France's liberation? It was a heartbreaking account of his inability to convince the general of the importance of the political and diplomatic side of things - and ultimately of the relevance of a provisional government for France - and therefore of his failure to secure for Giraud, for the Five, and ultimately for France the fruits of the Allied landings in which they had played a significant part.

What of the North African resistance? Swept away by de Gaulle, the North African resistance was almost forgotten or portrayed in partisan fashion as part of Vichy's last desperate attempt to hold on to power, aided and abetted, of course, by an overbearing America that pulled the strings. It was part of Lemaigre Dubreuil's own postwar task to separate the activities and aims of Giraud and the Five from those of Vichy. It was a difficult assignment for he held Giraud, perhaps unfairly, responsible for much that had gone wrong: 'You came to Africa as a revolutionary,' he told the general. 'But after four months your words and deeds had enshrined the spirit of Vichy in Algiers. ${ }^{64}$ Ironically, Lemaigre Dubreuil received his most important boost in an unexpected letter from President of the Republic Vincent Auriol, who, years before, as Léon Blum's Minister of Finance, had tangled with Lemaigre Dubreuil over government policy and the Bank of France. After reading Lemaigre Dubreuil's account of the North African landings in Les Relations francoaméricaines et la politique des généraux, Alger 1940-1943 (Paris, 1949), he wrote:

I can assure you that in all my speeches and especially in my conversations with foreign diplomats, I will insist on the fact that, although France was gravely wounded at the start of the war and remained unassisted until the end, as a result of its sublime and heroic internal resistance, its far-sighted external resistance, its daring African resistance, its military successes in Italy, Germany, Tunisia, and France, the courage of its soldiers in and out of uniform, and the suffering of its people, it always remained faithful to its duty, its honor, and its Allies and must be recognized as the stalwart ally that it was from the very first in 1939.

This was the stuff of presidential addresses, but there was some magic in it. Auriol ended the letter by personally thanking Lemaigre Dubreuil 'for what you did, together with the other members of the African resistance, to prepare for the landings. ${ }^{65}$ In addition to the croix de guerre avec palmes, the military decoration that Giraud awarded him at a ceremony in Algiers on the first anniversary of the landings, this was the only official mark of gratitude for his North African effort that he ever received. 


\title{
5 To die in Casablanca
}

\begin{abstract}
'Au terrorisme s'oppose actuellement un anti-terrorisme qui va croissant. Les différents qui se soldent par des cadavres ne résolvent rien.'

'Opposed to terrorism there is an anti-terrorism which is on the increase.

But disputes that are measured in dead bodies never resolve anything.'
\end{abstract}

Jacques Lemaigre Dubreuil

In 1949, Lemaigre Dubreuil sold his Algiers villa, the Five's command post for almost two years, and purchased Dar Balek in the Oudaïas district of Rabat, overlooking the Bou Regreg river toward Salé. Although Casablanca, less than 50 miles to the southwest, was the Moroccan headquarters of Lesieur-Afrique (Casablanca), Rabat was the city that for over three decades had been the administrative capital of the French protectorate and the sultan's principal residence. Business advanced Casablanca just as politics dominated Rabat. And both continued to be a part of Lemaigre Dubreuil's life.

When the Casablanca refinery opened in 1944, followed by the Algiers factory four years later, Lesieur-France and Lesieur-Afrique were linked in a diversified network of production and distribution unlike anything in the pre-war years. From Dakar Lesieur still imported peanuts for crushing and peanut oil for refining to its complex near Dunkirk. But Senegal's peanut oil was also shipped directly to Casablanca and Algiers to be refined and bottled, then exported within the empire (now christened the French Union) and beyond. In addition, both the Casablanca and Algiers plants refined native olive oil, consumed locally or sent to France; Algiers manufactured soap as well.

In the decade after the war Lesieur-France was part of France's economic resurgence. It reported capital assets of 1.4 billion francs (1953), claimed first place among French producers of vegetable oil, and boasted a truly national reputation for Huile Lesieur. And in Morocco, too, Lesieur-Afrique was the largest producer of refined cooking oils, accounting for 45 percent of the annual output of the eleven vegetable oil companies in Morocco and 71 percent of their total sales. Much of this was due to the aggressive entrepreneurship of Lemaigre Dubreuil, who sought out Moroccan investors for Lesieur-Afrique, engaged Lesieur in creative marketing practices throughout French Africa, and took the lead in 
establishing the Huileries Réunies, an industry-wide consortium of all the French vegetable oil companies in Morocco. ${ }^{1}$

If Lesieur participated in an impressive way in the making of Casablanca's industrial district at Roches Noires, helping to transform the city into a real 'Chicago on the Atlantic,' Lemaigre Dubreuil was equally invested in Morocco's political future and some enduring form of Franco-Moroccan cooperation amidst the postwar talk of colonial independence. What moved him to join the political fray was the American criticism of France's colonial record in Morocco at the United Nations at the end of 1952. Since this coincided with the election of Eisenhower to the presidency of the United States, Lemaigre Dubreuil found it appropriate to recall - in an article for the Paris financial newspaper L'Information politique, économique et financière the reversals and inconsistencies of America's wartime policy in North Africa. ${ }^{2}$

He reminded his readers that despite the American commitment before the Allied landings to respect the sovereignty of France and its empire, three months after the landings President Roosevelt had encouraged Sultan Sidi Mohammed Ben Youssef at the Casablanca Conference to hope for independence. And now, ten years later, any regard for French authority in Morocco seemed to have disappeared, together with any appreciation for what France had accomplished in its Moroccan protectorate. Lemaigre Dubreuil insisted that present-day colonialism concentrated on the human side of things, the 'intensive development' of the resources, the infrastructure, and the products of the countries involved, sometimes to the detriment of the Metropole itself, but always improving the life of the colonial population and ever directed 'in a progressive way' toward their emancipation. What then was America's disapproval based on? Morocco was 'attractive' to the United States from the economic, geographic, and strategic points of view. And he suggested that in the Cold-War world both markets and military bases were the real reasons for America's interest, masked by an anticolonial rhetoric and encouraged by Moroccan nationalists who saw American support as critical to their own plans for political power, whether or not they were ready for its responsibilities. In truth, a heightened American involvement in Morocco might benefit the Moroccan economy. But Lemaigre Dubreuil wondered how America's sense of its own superiority as well as its vast riches and power would contribute to Morocco's political and 'spiritual' well-being. ${ }^{3}$

How well had France fulfilled its duty to educate the Moroccan people for self-rule? Lemaigre Dubreuil noted that the sultan was eager to form a government to discuss Morocco's future with France, but he would only accept a government designated by and responsible to him alone. This proved that at the present time he had little confidence in the viability of democratic institutions in his own country. And, therefore, France had been correct to move prudently with its Morocco policy, carefully preparing the groundwork for the future and in particular spending the necessary time to educate the native 'elites' needed to run the government. What is more, France was the one common denominator in a society that only decades before had lived in complete anarchy, so unity not division was France's goal and its enduring legacy. And frankly, mutual understanding and sympathy between Frenchmen and Moroccans had always played a 'fundamental role' in the 
evolution of the country and its possibilities for emancipation. Finally, one fact dominated all others: the 'feudal' nature of Morocco's institutions and its customs, best revealed by the sultan's role as both the political and spiritual leader of the country. In sum, Lemaigre Dubreuil agreed with the sentiments of his new-found ally, President of the Republic Vincent Auriol, who, also exasperated by American criticism, had spoken with conviction at the end of October of the 'benefits of the French accomplishment in North Africa,' pointing out the bitter truth that it was always easier for America to teach lessons than to provide examples. ${ }^{4}$

At the same time Lemaigre Dubreuil expressed his own views on the current impasse between the French government and Mohammed Ben Youssef on the future of the protectorate. France desired to maintain the protectorate treaty intact the 1912 Treaty of Fez - until a democratic state could be created that was 'predominantly Moroccan' in its political leadership and which over time would become entirely Moroccan in direction. This might take years or even decades. On the other hand, the sultan, supported by nationalist groups - such as Istiqlal, the Independence Party, formed at the end of the Second World War - and backed by growing popular sentiment, wanted the immediate revision or abolition of the Fez treaty and the designation of a Moroccan government empowered to set up the institutions of a constitutional monarchy and to negotiate a new relationship with France. Lemaigre Dubreuil admitted that the French stance blocked the road toward emancipation by delay or design; yet the sultan's plan delivered Morocco over to a traditional ruler with only a nod toward democracy and without a whisper about the historic or political rights of France or Frenchmen. ${ }^{5}$

His solution was for both parties to recognize that the Treaty of Fez was no obstacle to their agreement. While still in place, it could allow for Moroccans to take over some of the responsibilities of government almost immediately and permit top sharifian officials - such as the sultan and the Grand Vizier - to take back the authority that they had long ago ceded to protectorate administrators. But this should not happen unless certain conditions had been met. 'The government and administration of Morocco must not be turned over without recompense, without reciprocity, and without some time limit on the unbridled discretion of an appointed and unelected government.' He suggested that the rights of the 'foreign interests' that had contributed to Morocco's development had to be protected as well as those of non-Moroccans (perhaps through dual citizenship) and Jews. And he sketched a plan for representative political institutions to be established from the municipal to the national level culminating in one or two national assemblies. Such a program would take time to realize, he admitted, but that was the point. It was much easier to name a government of men than to create a government of institutions. And this was why the role of France - in close association with Morocco - was so 'indispensable.' He concluded his essay with the hope that the 'joint efforts' of the French Republic and the sultan would bring about Morocco's emancipation 'in complete tranquillity.'6

Despite Lemaigre Dubreuil's almost genetic aversion to protectorate bureaucrats and unreconstructed colonials, this was a vigorous defense of colonialism, a prose version of the iconic illustrations of the 1950 s that showed Marianne on the march, 
brandishing her torch of human freedom with the colonies shoulder-to-shoulder at her side or following close behind. This was the glorious, generous, democratic, reformist, enlightened France in combat with its ancient enemies - ignorance, poverty, brutality, and tyranny. But the Treaty of Fez meant more than that, for it preserved France's essential rights in Morocco from the diplomatic to the financial, and especially the legal rights of Frenchmen (and other foreigners as well), allowing them to reside, engage in commerce, and possess property in Morocco. Moreover, should the Treaty of Fez disappear and the protectorate with it, Frenchmen would have no means of direct action on the Moroccan government. This is why Lemaigre Dubreuil spoke of conditions or guarantees before France could ever give up the protectorate regime for something else, even Moroccan membership as an 'associated state' in the French Union. ${ }^{7}$

Events spoiled the tranquillity that Lemaigre Dubreuil desired. Within days after Lemaigre Dubreuil's article appeared, the Tunisian labor leader Ferhat Hached was ambushed and killed by French counter-terrorists who sought to frustrate Tunisia's break with France. The Casablanca response to the death of this first martyr to the North African cause was a general strike and a weekend of marches and demonstrations that turned violent, resulting in the deaths of several Europeans and hundreds of Moroccans. The public in France was shocked by the brutal news reports from Casablanca. And Frenchmen in Rabat were outraged by the stance of Catholic intellectuals, who with Nobel laureate François Mauriac in the lead pleaded for Frenchmen in the colonies not to commit the sort of crimes that the Germans had committed at Oradour-sur-Glane in 1944. Livid at the comparison, Lemaigre Dubreuil wrote to Minister of Foreign Affairs Georges Bidault that Mauriac had implicated him in a 'collective crime' that absolutely nothing justified. 'I did not lock any Muslim man, woman, or child in a mosque and then set it on fire so they would perish in the flames ... I came to Morocco to be of some use to this country which both Mr. Mauriac and I watched come into being. And not to be implicitly accused by this member of the Académie Française - who is somewhat careless of how he uses his reputation, his honors, and his audience - of being a torturer and an assassin.' He ended his letter with an expression of 'deep indignation' over Mauriac's words that he insisted had now been added to the 'sorrow' that he felt over the Casablanca events. ${ }^{8}$

Unlike Mauriac, many Frenchmen and more than a few Moroccan tribal leaders held the sultan responsible for the Casablanca 'events,' for he had been present in the city and done nothing to avert them. The politically ambitious and stalwartly pro-French pasha of Marrakech, Thami al-Glawi, appealed to the protectorate government to 'put a quick end to the reign of the Sultan of Morocco,' whose removal, he contended, was the 'sine qua non of peace and loyal collaboration between France and Morocco.' ${ }^{\prime}$ And the elected representatives of the French population of Morocco also had had enough of over-heated national passion. They sent a delegation to Paris to ask for 'the removal of any person, regardless of his rank or function, whose presence constitutes an obstacle to the accomplishment of France's mission in Morocco.' 10 The name of Mohammed Ben Youssef was now written in bold letters on the Palais Bourbon's wall. 
On the other hand, in a curious article for L'Information Lemaigre Dubreuil blamed the December riots on what he called the 'internationalization' of the Moroccan crisis, comparing the present scene, heavy with both American and United Nations involvement, to the situation at the time of the thirteen-nation Act of Algeciras in 1906. His point was that international solutions had consistently failed to achieve any lasting peace or progress as far as Morocco was concerned. Six years after Algeciras, France 'was forced' to impose its protectorate 'with Europe's blessing.' This was proof enough for him that until the advent of the French protectorate - and despite the grand designs of the Great Powers - chaos, death, and double-dealing, reform-reluctant sultans had ruled Morocco. With France and the Treaty of Fez finally came ' 40 years of stability, 40 years of prosperity.' Similarly, the current 'drama of Casablanca' had been propelled by a Morocco in the world spotlight, a sultan on CBS News, and independence leaders at the UN. In the streets of the medina there was even evidence of cooperation between nationalists and communists; and perhaps some connection - America beware! - to Red China. Lemaigre Dubreuil believed that France should take its responsibilities very seriously in Morocco, but handle this matter alone, 'regardless of the national and international consequences that might result from this decision.' The time had come to see whether Paris would be able to follow 'the policy of dignity and strength' that had marked the path of its predecessors. More than ever before French policy in Morocco had to be 'thought out, defined, and executed.' 11

This was a novel if fanciful rendering of Morocco's history and France's role in it, distorted by dead-wrong notions that in world events 'the same causes produce the same effects' or 'the same effects evoke the same causes' and even that history itself 'is nothing more than a perpetual new beginning.' But it did lead to a stunning reform proposal - 'effectively and definitively orienting Morocco toward its independence' - which could only be implemented by France, acting within the framework of the Treaty of Fez 'and only within this framework,' together with Mohammed Ben Youssef. Within six months France would turn over to 'responsible Moroccans' (Marocains valables) the administrative positions that they were capable of assuming. Lemaigre Dubreuil had no doubt that such qualified men existed, although such a sea change, so difficult to manage and so fraught with problems, might necessitate that this 'ungrateful task' be presided over by a political leader who was both a member of the Paris government and empowered to act in its name. At the same time a constituent assembly would be established in Rabat numbering 120 delegates, half chosen by the sultan from among the Makhzen, the tribal councils (djemaas), and the various religious, commercial, and agricultural groups within the Moroccan community; half selected by the French from among the protectorate administration, the elected representatives of the French population, the chambers of commerce and agriculture, and the trade unions, employers' groups, and civil servant organizations. This assembly in turn would authorize several sixmember committees to prepare the basic statutes that would govern all areas of Franco-Moroccan life, eventually submitting them for the advice and approval of both the French and Moroccan governments. ${ }^{12}$ 


\section{The assassination of Jacques Lemaigre Dubreuil}

To be sure, Lemaigre Dubreuil worried about the rights of France and Frenchmen and how to safeguard them. He proposed dual nationality or dual citizenship for Frenchmen (which would be reciprocal for Moroccans resident in France) to allow them voting rights at all levels of government in order to defend their political interests and especially to protect their not-inconsiderable economic and financial investments. He suggested that Moroccan troops remain integrated within the French army as part of a common Franco-Moroccan defense force 'until some future new order.' And he proposed - even while admitting that this would be the most difficult for Moroccans to accept - that Moroccan foreign policy remain 'merged' with that of France, arguing this alone could give France the guarantees that it had 'the right to claim.' With such conditions as these this might seem a 'strange sort of independence,' but Lemaigre Dubreuil added that Morocco, like France, would soon be part of the supranational world system of the future, leaving nationalism, its passions and its militants far behind. He described France's ongoing role vis-à-vis Morocco in a somewhat jumbled yet visionary way: 'parachuting' Morocco from the feudalism that still dominated three-fourths of the country and from the 'narrow nationalism' that ensnared the final fourth to 'an international stage' where the progress of science - albeit 'not without its problems' - shaped the course of human existence. Together, these two countries 'in a completely different and reassured atmosphere' might resume their 'Mediterranean vocation.' 13

Written in Lemaigre Dubreuil's candid style, bereft of official platitudes, and urgent in its call for quick, generous, and collaborative action, this proposal intrigued, confused, and infuriated readers in both France and Morocco. It provoked a dialogue with some of Lemaigre Dubreuil's closest Moroccan friends, such as writer Abderrazak Berrada, who took him to task for his ignorance of Morocco before France (as if both Morocco's past and future had only begun with France), its Islamic heritage and civilization, and its long-standing and important contacts with Africa and the Middle East, in short, the essential contours of its history. Berrada argued that Moroccan nationalism could only be understood in the context of the postwar effervescence of ideas across the entire Muslim world and had little in common with European nationalisms of the German or Italian sort. And that independence was only a starting point - not an end in itself - to enable Morocco to re-think its position and role in the world. He also challenged each of Lemaigre Dubreuil's political propositions, including the idea that democracy had to come from the bottom up (for Berrada the only way was with political education from the top-down), and his various reform proposals, particularly the 120-member constituent assembly which Berrada imagined would produce a constitution like that of 1922 Egypt, written by 'foreigners' out of touch with society's realities and unresponsive to its needs. ${ }^{14}$

Lemaigre Dubreuil's attitude toward these matters Moroccan was decidedly conservative, even reactionary, at least judged by Berrada's standards or the nationalist agenda. He was not 'liberal' (even though he was called so in the French press) except in the sense that he advocated an alternative to the policy of force demanded by the political leaders of the French community in Morocco and 
implemented by the protectorate authorities. But his means of reaching that alternative, whatever it might turn out to be, was unique at a moment of growing intolerance between the French and Moroccan communities. 'Persuaded that the solution to any problem involving Franco-Moroccan relations lies in the objective, loyal, and trustful confrontation of respective viewpoints,' he promoted a Franco-Moroccan dialogue, including the creation of a formal Franco-Moroccan Association. ${ }^{15}$ As he saw it, his role was to identify genuine spokesmen for Moroccan national opinion, then convince the French government and the French community in Morocco that they did indeed represent authentic national sentiment, and finally to persuade all parties to participate in discussions that would lead to a resolution of political differences.

Had he done something like this before? Perhaps. He had enlisted Giraud in the North African conspiracy, helped to convince America that he was the French leader it wanted, and worked tirelessly to secure an agreement between him and American representatives that promised Allied status for North Africa as well as the postwar restoration of France and its empire. Once again he weighed in on the side of persuasion and negotiation. But in this case, whether or not to talk with the sultan and to include nationalist spokesmen in the conversation was the most explosive political issue of the moment, and here he had made his personal choice.

Lemaigre Dubreuil's notions were based on the conviction that the Moroccan elite desired far-reaching reform, not a revolutionary break with France. And that it made sense for Frenchmen to support reform-minded change as an alternative to something far worse. His circle of friends within the Moroccan business and professional community - such as M'hamed Zeghari, vice-president of the Moroccan Chamber of Commerce and Industry of Fez, and Centre des Jeunes Patrons leader Ahmed Ben Kirane - reinforced this notion. Both encouraged him to form a study group to permit reform-minded Moroccans and Frenchmen to discuss political change in an open, confident atmosphere. This he did. For twoand-a-half years these meetings would serve to foster the free exchange of ideas at a time when organized political activity was illegal, the Moroccan press censored, and private meetings suspect. In these gatherings lawyers and business leaders Muhammed Boucetta, Abderrahim Bouabid, Hadj Omar Abd el-Djellil, and Ahmed Ben Kirane spoke for Istiqlal, the Independence party formed less than ten years earlier. ${ }^{16}$ Abbed Soussi, Abdel Ouahad Ben Jeloun, M'hamed Dadi, and M'Barek Ben Bekkaï, the former pasha of Sefrou, expressed the opinions of moderate, independent, non-party nationalists. ${ }^{17}$ And Major Henri Sartout, director of the Casablanca daily newspaper, Maroc-Presse; Lorrain Cruse of the Compagnie Africaine de Banque and the Compagnie Sucrière Marocaine; and Jacques Reitzer of the Compagnie Fermière des Eaux d'Oulmès-État voiced the views of the liberal French business community. ${ }^{18}$ This group would regularly expand to include political personalities of all sorts from Morocco and France.

Lemaigre Dubreuil's January 1953 plan evoked no official interest, prompting him to ask - again in L'Information - if the government had a Moroccan policy of its own to end the ongoing 'dialogue between deaf mutes' as he called the political stalemate between the sultan and the Residency. What would it take, he wondered, 
to open the discussion on the 'real problem,' the need to move from the protectorate stage with direct French rule to a period of 'gradual emancipation'? He called on France once more to make clear the framework in which it would pursue these discussions; the responsibilities, the duties, and the powers that it was willing to hand over to the Moroccans; the rights and the interests that it wanted to protect for itself; and the precise steps (or timetable) to be followed in the emancipation process as well as the new institutions that were to be created along the way. Finally - and this was new, surprising, and powerful - he called on the "various interests' (pressions diverses) opposing the protectorate's evolution to stop what they were doing; and he asked the sultan and the Residency to start to converse openly again on Morocco's future. Most importantly, he appealed to France to quit treating the Moroccan people as 'minors' (un peuple mineur). 'The confidence that France shows in its protégés from this day forward will be an act of faith in its own colonial vocation as well as in its own national and international destiny.' When would the Quai d'Orsay - and in truth all Frenchmen - realize that since France had contributed to the formation of an 'elite' in Morocco, it could hardly ignore the wishes of an educated public that 'almost unanimously' desired to rally around a national program influenced and inspired by France? And how could France ever expect to call on this Moroccan opinion for support if it failed to remove the obstacles or resolve the disagreements which prevented France from fulfilling its mission? ${ }^{19}$

Chided for his persistence with plans that relied on dialogue at a time when anger and tough talk seemed the order of the day, Lemaigre Dubreuil answered that despite 'all the mistakes' made by France, just when things looked the very worst there might be a turn for the better. ${ }^{20}$ Despite this 'foi du charbonnier, ' the worst came in summer 1953. The campaign against the sultan reached its frenzied peak with a petition to the French government denouncing Mohammed Ben Youssef signed by more than 280 pashas and caïds and coordinated with staged manifestations against the sultan throughout the country. The pasha of Marrakech was the petition's principal framer, guided and egged on by French officials in Rabat and key members of the colonial community. Lemaigre Dubreuil took this as another sign of Paris's abdication of its responsibility, 'the total collapse of French thought, imagination, and will since the death of Lyautey.' By doing nothing, France was condoning, even encouraging the unraveling of Moroccan unity as well as stimulating multiple and sometimes conflicting 'appetites and hopes' that promoted the sultan's overthrow. But the removal of a monarch of a 'protected' country could only demonstrate the failure of that protection and the absence of any political resourcefulness on the part of the protector. 'France has everything it needs to restore this situation that it compromised by its own lack of action,' Lemaigre Dubreuil wrote in his first essay for Le Monde. 'But make no mistake, a coup de force is not a policy. It is only the illusion of a policy to grant temporary mental relief and to delay acting more thoughtfully.' He pointed out that the Frenchmen who pressed for such action failed to realize that it violated the very treaty that they claimed to support and it undermined a French government that they counted on for the defense of their interests. And the success of the petition 
drive itself damaged the authority of the Makhzen, the key institution through which the protectorate operated, and put France in the uncomfortable position 'instead of recognizing its mistakes and the responsibilities of its failures' - of preferring the pasha of Marrakech to the legitimate ruler of the country simply because over time the sultan had become 'quarrelsome and unmanageable.'21

All this moved farther from rather than closer to a solution of the Moroccan problem. 'It is high time,' urged Lemaigre Dubreuil, 'that France itself makes a decision.' The Moroccan matter was a 'governmental matter' (affaire de gouvernement) and only someone attached to the office of the président du conseil du gouvernement, entrusted exclusively with this difficult and long-term assignment, adept at working with parliament, and willing to accept all the responsibilities that the task entailed could succeed in introducing the needed reforms. Until now, as a result of 'a lack of ideas, of policy, of direction,' anarchy ruled in Paris. And he confessed, reflecting publicly on his displeasure with Mauriac, that he was 'painfully surprised' to see 'eminent Frenchmen' blame the administration in Rabat for the 'tragic results' of the repression of the Casablanca 'uprising' (émeute) which was in truth another consequence of the metropolitan 'collapse.' 'The time has come,' he repeated, 'when the French government must take a position on the Moroccan problem.' First, 'an atmosphere of understanding and collaboration' had to be created for 'acts alone will demonstrate on both sides that Franco-Moroccan confidence is a reality.' 22

Lemaigre Dubreuil ended his essay with a haunting personal reflection on the feast of Aï Seghir, celebrated in Rabat as a day of 'sadness and mourning' because of the current Franco-Moroccan crisis. What 'curious and lamentable' policy could have brought this about? 'Though some would have us believe that we should, by means of force, subdue and rule this endearing people (ce peuple si attachant), others cannot accept that we might, through an attitude of cruel indifference (la politique du chien crevé au fil de l'eau), bring to naught an endeavor born of confidence, consolidated in mutual esteem and hallowed by the blood shed on countless battlefields.' 23

However, two months later on 20 August Resident General Augustin Guillaume ordered the sultan's dethronement and exile, first to Corsica, then to Madagascar. Mohammed Ben Youssef was replaced by an aged and compliant uncle, Sidi Mohammed Ben Arafa, now guided by the pasha of Marrakech. Although the protectorate authorities hoped that the sultan's departure would stifle the national movement, exposing the nationalists as a communistinspired band of Cold-War agents provocateurs or Arab League fanatics, this did not happen. A sterner plan for national independence gained in moral strength and physical support as the Moroccan population resisted the sultan's exile. And this resistance - shop closings in the medinas, the boycotting of French goods, and the targeted and random acts of terror against Frenchmen and their Moroccan 'collaborators' - quickly deepened the divide between the two communities. For Lemaigre Dubreuil this was the low point of FrancoMorocco solidarity even though collectors of the postage stamps of French Morocco would never have guessed it. They continued to be treated to 
elegantly designed and engraved postal issues proclaiming French good works and Franco-Moroccan friendship.

Lemaigre Dubreuil pushed on with his policy of Franco-Moroccan dialogue, but it was difficult to know with whom. Forced to admit in a second article for $L e$ Monde that the sultan's ouster may have been 'inevitable' since he had revealed himself to be an 'enemy' of France and had 'served himself' at the expense of his people - a reference to the sultan's 'immense fortune' - he added that the Moroccan question was far from settled. Again, he denounced what he called 'the utter poverty' of political ideas that for so many years had debased France's role as Morocco's protector. And he blamed this absence of ideas for encouraging the development of an anti-French opposition that had been 'constantly on the increase' and made more troubling because ultimately Mohammed Ben Youssef had become its heart and soul. But now with the sultan gone (and Lemaigre Dubreuil was sure that he would not be coming back), what was to be done? ${ }^{24}$

The first positive act of what Lemaigre Dubreuil properly called a 'palace revolution' had to be the separation of powers, the divorce between religion and the state that formed the basis of all modern democratic governments. The new sultan would remain the spiritual commander of the faithful, but Moroccan political authority should be exercised by a Franco-Moroccan government (conseil $d u$ gouvernement franco-marocain) chosen by yet-to-be-formed regional and municipal representative assemblies. This would happen once the Quai d'Orsay finished writing Morocco's new constitution! Next would come the reform of the justice system - in the main the replacement of the antiquated and inequitable pasha's courts - but somewhat slowed in its implementation by a lack of qualified Moroccan jurists. If France pressed ahead with these political and legal reforms in cooperation with the new Moroccan leadership, there was yet a chance for a sincere Franco-Moroccan partnership. But if not, then all was lost. ${ }^{25}$

Together with these 'advantages' to the new situation Lemaigre Dubreuil listed its 'perils.' The first was surely that many Frenchmen had the impression that with the change of sultans the Moroccan question was decided. 'Nothing was further from the truth.' In fact, this was but the 'simple prologue' to a drama that had yet to be played out. He warned against the voracity of the beneficiaries of the new regime, both Frenchmen and Moroccans, and pleaded for a resident general who would make his voice heard above the crowd and, ever conscious of France's role as the 'protector nation,' enable Moroccans to take their destiny into their own hands. He worried about wounded Moroccan national pride in the 'new order' and argued once more that the creation of a supra-national union, a Franco-Moroccan federation, would temper this sentiment and serve as a positive step toward a future European federation. Finally, in a telling and belated first-time proposal, he touched on economic concerns, suggesting that both French and Moroccan businessmen ought to work 'little-by-little' to increase the standard of living for Moroccan workers, yet immediately establish Moroccan workers' councils (djemaas ouvrières) whose representatives would meet with company and industry-wide management on all matters of mutual interest. $\mathrm{He}$ ended on a characteristic high note, asking each Frenchman and each Moroccan 
to contribute to the making of the new Morocco, looking forward rather than backward and moving very quickly. ${ }^{26}$

Despite the growing attention to Moroccan matters in France - shown by Le Monde 's continuous publication of Lemaigre Dubreuil's views beginning in June 1953, the formation of a prestigious Comite France-Maghreb in the same month, and North African reform rumblings from a potential candidate for premier, Pierre Mendès France - there was little progress where it counted most: at the Palais Bourbon or in the Residency at Rabat. ${ }^{27}$ Despite all the interest, Lemaigre Dubreuil believed that the situation in Morocco was deteriorating and he wondered what sort of 'catastrophe' it would take to drive the French government from its 'lethargy.' From Tetouan and Cairo came regular radio incitements to terrorists in Casablanca, yet Paris did nothing. And each day in Rabat or Marrakech acts of violence of one sort or another cost the life of 'one or more of our friends,' yet police measures and the use of force stopped no one. Switching the sultan had not improved things and changing the resident general would only make things worse - unless the policy of France changed as well. 'Unfortunately,' he fretted aloud, 'a vacillating, poorly-organized, badly-ordered democracy such as that of the Fourth Republic seems totally incapable of defining, then imposing its will. To determine policy implies an effort of continuous and constructive imagination, a desire to rise above numerous individual interests and to harness them in the service of the national community.' Morocco was the 'keystone' of France's 'entire African system,' yet nothing was being done to keep it in place. In despair and with deep regret he concluded that History would hold all those governments accountable which, as a result of mistakes or inaction, had compromised 'one of the most spectacular achievements' of the modern era, accomplished for the benefit of France and for the Moroccans themselves. ${ }^{28}$

The attempted assassination of Sultan Moulay Ben Arafa as he left his prayers at the palace mosque in Marrakech was a catastrophe-in-the-making. One photograph, flashed to news services around the globe, showed the badly shaken yet unharmed 'noble vieillard' wiping the splattered blood of his less fortunate companions from his face, a confused, hapless, and sympathetic victim. An equally horrifying and unforgettable photo, taken moments later, captured the hard-bitten and unforgiving pasha of Marrakech holding the smoking revolver with which he had personally executed one of the sultan's grenade-throwing assailants. Only the swift intervention of French officials, so went the accompanying report, had prevented him from dispatching the others. The second image (and the story that went with it) suggested a text to Lemaigre Dubreuil: the clash of two cultures, two ideas of justice and two ways of doing things. And the apparent inability of Paris to choose between the two or (and this was his real point) to decide on any policy at all. These 'pathetic hesitations', which he had denounced 'with anger in his heart' just weeks before in Le Monde had now become part of the Moroccan tragedy, encouraging assaults in mosques, such as this one on Ben Arafa, and terrorist attacks in Morocco's urban centers almost every day of the week. Perhaps to provoke a discussion, Lemaigre Dubreuil said he would opt for the pasha's justice since a 'revolutionary situation' demanded revolutionary 


\section{The assassination of Jacques Lemaigre Dubreuil}

measures, something 'immediate and spectacular' that would grip the popular imagination. But would France run the risks and accept the consequences of such revolutionary justice? And if not, just what would France propose? ${ }^{29}$

He proposed prompt action to show clearly that France intended to command both individuals and events - by substituting the current 'all-powerful and suffocating' (pléthorique et souveraine) protectorate administration with something 'shared and decentralized,' by re-invigorating the Makhzen, and by enlisting the cooperation of everyone who was committed to building the 'new Morocco.' Without this bold, imaginative, constructive, even 'revolutionary' action from Paris, the initiative would pass to Istiqlal which had already proven beyond question that the departure of the former sultan had in no way reduced the force of the movement for independence. Terrorism itself emerged from the simple notion, concluded Lemaigre Dubreuil, that the state no longer represented the 'idea of strength' (la notion de force). And it would only cease when the majority of Moroccans became convinced that the state had regained this authority, not only by the strength of its arms but by its creative acts as well. ${ }^{30}$

When Resident General Augustin Guillaume was promoted up and out of Morocco, Lemaigre Dubreuil lobbied in print to Premier Joseph Laniel for a successor who would press forward with a reform agenda. He noted that this would be the first time since the dethronement of Mohammed Ben Youssef that a new resident would be faced with presenting a program to all Moroccans - 'the average Moroccan, the man in the street, the Moroccan from every class of urban and rural society' - and not just the sultan in order to convince them that France had the.will to make the changes that were needed. The task was tough and so the choice of the resident was of 'exceptional importance.' Recognizing that Laniel's government was itself strapped with other domestic and international problems, he reminded the premier that Morocco was 'the most important'of France's overseas lands and warned: 'If the choice of the resident and the new policy he is to implement does not coincide with the needs of the hour, then a Moroccan tragedy (le drama $d u$ Maroc) might well be joined to the tragedy of Indochina.' ${ }^{31}$

He repeated his criticisms and suggestions in a long essay for Le Monde which he called 'Morocco in Danger.' To underscore the human factor in the Franco-Moroccan equation - and now the human element seemed even more important to him than the text of treaties - he related the story of a delegation of Moroccan notables who on the news of the fall of the French fortress at Dien Bien Phu in northern Vietnam (on 7 May 1954 after an agonizing 55-day siege) pressed their condolences on a French territorial administrator. Morocco had always stood by France both in good times and bad, they told him, and so they were deeply moved by what had happened in Vietnam. They asked if Moroccan troops had been part of the French contingent at Dien Bien Phu and wondered if he could find this out for them. And then to the surprise of the French official, who assumed that they were worried about Moroccan lives lost, they expressed the hope that Moroccans had in fact been fighting side-by-side their French comrades, especially at this moment of calamity. These were the same Moroccans, Lemaigre Dubreuil noted with chagrin, who, because the protectorate had failed to evolve, would soon be transformed into enemies of France..$^{32}$ 
'Such a situation,' he offered, was 'hard to believe.' More and more Frenchmen in Morocco had come to realize that French policy had failed and now were insisting that the government define its goals and explain how it hoped to reach them. France had to proclaim its desire, its intention, its determination to give Morocco 'its complete sovereignty.' Even though this sovereignty would come at a time 'impossible to determine today' and depend on the ability of Moroccans 'to take their destiny into their own hands,' to make it happen France needed to implement 'radical changes' in the administration of the country. Only by managing their own affairs would Moroccans be able to develop a clear understanding of the rights, the duties, and the talents necessary to achieve the 'total equality' they wanted. ${ }^{33}$

All this required a 'confident Franco-Moroccan collaboration,' based on the support of the 'best elements' (éléments valables) within the population and predicated on the rejection by the government of the 'disastrous and often reactionary' policies of the past. Lemaigre Dubreuil hoped that a resident general presiding over a joint Franco-Moroccan committee - and the diplomat Francis Lacoste had been named resident the day before (20 May) - would decide on the key principles of a new policy. He suggested that it include a statute establishing Morocco as a constitutional monarchy, a statute defining the rights (and protecting the interests) of Frenchmen, and a statement describing the future of Franco-Moroccan relations. From these documents all else would flow, including a solution to the thorny question of the sovereign which Lemaigre Dubreuil, influenced by the testimony of the streets and the witness of his Moroccan friends, now identified as an unresolved issue. The government had a choice. Either to continue a policy which had 'no other goal than to ensure and to entrench numerous privileges' or 'deliberately' to promote emancipation, performing with some degree of dignity its 'final act' as Morocco's protector. To be sure, Lemaigre Dubreuil admitted, Morocco needed law and order, but not by pitting the police against the terrorists, the countryside against the cities or the Berbers against the Arabs. Real law and order only came by creating unity, 'unity for freedom' and freedom for Morocco to associate itself 'in complete independence' with France. ${ }^{34}$

To press home his point he tackled the issue of terrorism. After the exile of Mohammed Ben Youssef, terrorism emerged as the 'brutal manifestation' of Moroccan discontent with France. It increased day-by-day in direct proportion to the expansion of measures enforcing police rule. Yet since Istiqlal disavowed these acts of terror, even while exploiting their impact for the benefit of the Moroccan 'resistance,' Lemaigre Dubreuil presumed that at this point in time 'diverse entities' directed from outside Morocco (anywhere from Cairo to Moscow and even much closer) were in truth calling many of the shots. Regardless of what inspired the terrorists, he feared that the 'scent of blood' in the cities would soon spread to the countryside, posing a 'very serious' danger to all Morocco. Everyone - the government as well as all Moroccans, Frenchmen, and Jews 'of good will' - had to work to restore order. ${ }^{35}$

Next he commented on the counter-terrorism of the French, born of legitimate outrage at terrorist acts and stimulated by a desire for revenge as well as a need for 


\section{The assassination of Jacques Lemaigre Dubreuil}

self-defense. Lemaigre Dubreuil believed that the need for self-defense was one of the 'most tragic and poignant' aspects of this situation. The police could not provide protection for the French community, forcing Frenchmen to take the law into their own hands and in consequence inflicting both counter-terror and vigilante justice on Moroccans. In addition to the counter-terror, police 'brutalities' against the Moroccan population contributed to Moroccan resentment, suffering, and hated which in turn provoked more attacks. This was the 'infernal cycle' into which Morocco had been tossed - to the delight of those 'outside' forces opposed to the recovery of France at home and abroad. What was the benefit, he wondered, of the numerous campaigns in favor of repression, this sort of 'repression demagoguery' which led to the exact opposite of the goals that were intended? Terrorism was an effect; attacking its cause was the only way to destroy it. When a resident general involved everyone in adopting measures that would protect the rights of all - including a measure to permit Moroccans 'to be masters in their own house' - then a 'common and united will' would emerge to end terrorism and to build a peaceful future. ${ }^{36}$

To help make this real Lemaigre Dubreuil brought a 'delegation' of Moroccan nationalists to France in early June to meet with influential Frenchmen in Paris. With some difficulty he arranged a meeting with Lacoste, who had not yet left for Rabat, but the resident general was a somewhat reluctant participant, perhaps fearing that Lemaigre Dubreuil had cast himself in the role of a political éminence grise and remembering the days of Giraud in Algiers, Lacoste wanted none of it. Nevertheless, the meeting itself went well. In other sessions the nationalists listened to Lemaigre Dubreuil and Félix Nataf (of Amitiés Marocaines) insist that it was a waste of time to make the restoration Mohammed Ben Youssef a 'precondition' to political discussions with France. However, they remained unconvinced and unmoved, even after future president of the Republic François Mitterand put it forcefully to M'Barek Ben Bekkaï at a dinner party discussion at Lemaigre Dubreuil's apartment: 'Excellency, you should never count on that. France would rather go to war!' 37

The rumor of organized French opposition to Resident General Lacoste even before he set foot in Morocco seemed further evidence to Lemaigre Dubreuil of the 'profound disorder' in Morocco - the upset caused by terrorism, the unhappy refuge in simple solutions of counter-terrorism and 'police repression,' and the 'great fear' that inevitably followed. Who could know what Lacoste would say or do before he said or did it? And who could presume to suggest that he would betray French interests? Once again the 'infernal cycle' had raised its ugly head. Now the new resident would have to do his best to allay the fears, calm the nerves, and foster concord. Order would come only when both sides took part in a 'frank discussion' (exposé loyal) of the interests they wanted to protect and the goals they wished to achieve. ${ }^{38}$

Yet French opposition to reform in Morocco only intensified with the formation of a government by Pierre Mendès France (on 19 June) who promised a 'real change' in overseas policy, concentrating first on Vietnam (pledging to end that conflict by 20 July or resigning if he did not), then on North Africa. Although 
Lemaigre Dubreuil told his friend M'hamed Zeghari, one of the June visitors to France, that the French government wished to follow a 'liberal policy' in Morocco, acts of terror and counter-terror complicated its task. ${ }^{39}$ The attempted murder of General Hubert d'Hauteville, head of the Région de Marrakech, on 20 June followed by the assassination ten days later of Dr. Émile Eyraud, director of $L a$ Vigie Marocaine, the newspaper with the largest circulation of any Frenchlanguage publication in the protectorate, left Frenchmen in no mood to reflect on the 'imperious necessity' (to use Lemaigre Dubreuil's phrase) of altering their relationship with the Moroccan people. Both men had played key roles in the sultan's exile and Eyraud, 'the prince of the ultras' as historian and liberal opponent Charles-André Julien described him, had surely been singled out for that reason. But as Lemaigre Dubreuil wrote Zeghari (and repeated in Le Monde), time was running out. To end the killing and find a peaceful solution to Morocco's crisis, it was necessary to 'act quickly.' Otherwise, time would work for those who wished 'at all costs' to prevent a Franco-Moroccan rapprochement, submerging everyone and everything in fear and bloodshed. 'This is not the moment for people of good will to go their separate ways,' he told his Le Monde readers, 'but the time for them to combine their efforts to restore a situation which can rapidly become tragic.' 40

In an academic but no less passionate voice Lemaigre Dubreuil summed up the Moroccan scene in the July issue of the Revue Politique et Parlementaire. He described Morocco as the 'jewel of our spiritual and temporal influence in Africa' and the geographic and strategic 'pivot' (plaque tournante) of three continents. Part of the Western bloc in the East-West competition as a result of its protectorate status, but in theory a sovereign state, 'French Morocco' had been reduced to direct rule in violation of its international position and the texts of Franco-Moroccan treaties. As a result, even though French tutelage would remain important for the foreseeable future, a 'new internal statute' for Morocco was an urgent necessity. This was the task of the new resident general, charged with moving the country 'little-by-little' from direct to indirect rule while at the same time shielding French interests. It was a tough task in a country that had experienced remarkable technical progress in a short time, yet remained at a 'medieval level' in terms of political organization and was comprised of several 'very different' social groups, among them a 'very conservative' rural tribal populace, a proud and courageous, impatient and angry city youth, and a large urban and rural proletariat. As in the past, Lemaigre Dubreuil called for 'calm' as the resident general pushed ahead with this endeavor, ever vulnerable to sabotage by terror or counter-terror. As the killing continued, France found itself faced with the 'frightful dilemma' of wanting to create a climate of FrancoMoroccan detente yet forced to take swift and 'atrociously brutal' police action against the terrorists. The answer to that predicament, he believed, was to be able to separate one's friends from one's enemies rather than falling into the old colonialist trap of tossing all Moroccans in the same basket. This is why it had been an error to remove the sultan, however difficult he may have become, and to imprison all of the nationalist leaders most of whom had no desire to see Morocco drenched in a 'bloody revolution.' In closing he shared his recurring nightmare that Moroccans 


\section{The assassination of Jacques Lemaigre Dubreuil}

would come to despise the 'great endeavor' that France had accomplished in their country and willingly wash themselves in the purifying 'blood of its destruction' so they would have nothing to remind them of this 'period of servitude.' ${ }^{41}$

Neither Paris nor Rabat heeded Lemaigre Dubreuil's advice to 'move quickly,' at least not on Morocco. Mendès France turned first to Tunisia (having met his Vietnam deadline with the Geneva accords of July) with a surprise visit to Tunis where at the Carthage Palace on 31 July he proclaimed the 'internal autonomy' of the Tunisian state. Any chance for Morocco about which the premier had been 'rather silent' until then, however, was spoiled by the impending debate in the National Assembly on the ratification of the European Defense Community treaty..$^{42}$ Moreover, the murder of Eyraud, so widely admired and respected in the French community, surely doomed any effort at Franco-Moroccan dialogue that even Lacoste might have desired, pushing the resident, the great hope of the liberals, toward police repression and the ultras. Despite all this, Lemaigre Dubreuil proposed ever more vigorous solutions, based on his growing understanding of the true dimensions of the Moroccan crisis and in consequence the inadequacy or wrong-headedness of the government's response. 'Whether our leaders (éléments officiels) like it or not,' he wrote in Le Monde, 'the revolution which is smoldering in Morocco (couve au Maroc) has its origins in the question of the sultanate.' By admitting that the events of 20 August 1953 had triggered a revolutionary terror he gave it an historic and patriotic justification, firmly dismissing all the explanations which held that outside forces, such as a world-wide communist conspiracy or the Arab League or even America, were somehow responsible for Morocco's current plight. These notions had appeared in his earlier writings but now, given his ongoing political education, he found them wanting. As a result, he called on Mendès France and Lacoste, both on record as firmly committed to the present sultan, to reopen the sultanate issue, acting as arbiters between the partisans of Ben Arafa and Ben Youssef. Without such action - admittedly a dramatic, even dangerous (and to some dishonest) shift in French policy - the disorder would continue. The solution Lemaigre Dubreuil proposed would confirm Morocco's sovereignty, ever promised by France but rarely demonstrated in deeds, by leaving the choice of the sultan to Moroccans themselves. Frenchmen would stand on the sidelines, guaranteeing the security, the freedom, and the 'total independence' of the process, as yet not fully explained. Neither proclamations, nor street demonstrations, nor petitions and counter-petitions could solve the problem. Only dialogue and the full and free expression of all opinions in an atmosphere of calm and order would achieve that goal. ${ }^{43}$

This remarkable little essay preserved the fiction of a sultan legally deposed by his own subjects and thus the legitimacy of the Ben Arafa regime. This was important for the partisans of Ben Arafa: for the Residency and its Moroccan co-conspirators who had organized the coup, for the French government who had installed him, and for the French population in Morocco who had desired the ouster of Ben Youssef. It also allowed for the validity of Ben Youssef and for the fierce, unyielding protest (including the acts of terror) of his supporters. As such, it occupied the middle ground, oftentimes the most vulnerable of terrains, and was unquestionably 
courageous. Perhaps best of all, it pulled France back from the thick of the fight, calling it a struggle among Moroccans, and giving Frenchmen the more appropriate and less perilous role of honest broker.

Three weeks later Lemaigre Dubreuil published a major article in Le Monde which he called 'Truths about Morocco,' emphasizing the importance of the sultanate issue once again, but also explaining the role of the protectorate's civil and military administrators in the deposition of Mohammed Ben Youssef. He said it was a 'simple but complete' account of the Moroccan situation at a time when things were getting worse, not better. Besides, such a story had become 'indispensable' to offer to a candid world, regardless of how painful it might be to French pride, since on the truth of this narrative rested the future of France's relations with Morocco and the Arab world as well as the future of French influence throughout Africa. ${ }^{44}$

He described the modernization of Morocco as a technological wonder accomplished over a short four decades that had been made possible by an 'internal political structure' (organization politique intérieure) that had put 'all of Moroccan life' into the hands of 'an important and often remarkable corps' of French civil and military authorities. Alas, this was at the heart of the current 'Moroccan tragedy' for this political carapace ultimately placed every pasha and caïd under French influence, in theory only under French supervision (contrôle) but in fact under direct French rule. Over time and especially with the development of a Moroccan national consciousness (une âme et une conscience nationales) the French administration set itself against anything that might undermine its control and the work it had wrought, yet it always insisted, even in the face of metropolitan or residential doubts that it was acting according to the 'so-called' will of its Moroccan subordinates. In addition, it allied itself with all the beneficiaries of the enormous wealth and the power that had come from Morocco's technical progress. So in a perfectly natural and understandable way an 'alliance' formed among all the 'profiteers of the regime,' joining together French administrators and colonists and many Moroccans as well. However, Lemaigre Dubreuil argued, this did not always correspond to what was 'necessary' for the Moroccan community. It often ignored the social and spiritual side of things, the human factor in the Moroccan equation. Moreover, since Morocco was a sovereign state entrusted to France to shepherd to complete 'emancipation,' this imposed certain obligations that went far beyond the purely technological. Thus, if France had succeeded in forging the 'material unity' of Morocco, it was much less certain that it had formed its 'spiritual unity' or, put another way, that it had ministered successfully to its 'soul.'45

The current crisis and the need to restore peace and order to Morocco as soon as possible required the resident general to act with dispatch, Lemaigre Dubreuil maintained, and at the same time to ensure that all his directives were carried out. And the first issue to raise in any Franco-Moroccan discussion had to be the sultanate, a matter for which France and its representatives shared 'a considerable part of the responsibility.' To pretend it did not exist, to deny the importance of something that 'grips the heart of the entire Muslim population' whether Arab or Berber, whether in the cities or among the tribes was 'to bury one's head in the sand' (la politique de l'autruche). Lemaigre Dubreuil called on the French 


\section{The assassination of Jacques Lemaigre Dubreuil}

government to 'declare openly' that the French administration in Morocco was 'responsible' for the exile of Mohammed Ben Youssef, which was 'not simply accepted but desired.' By admitting this, any subsequent Franco-Moroccan negotiation on the sultanate or any other question could proceed in complete confidence. And this truth, once conceded, might even allow Ben Youssef to reflect on his own role in Morocco's future, putting 'personal ambition' aside and sacrificing himself for the good of his people. By this Lemaigre Dubreuil implied that Ben Youssef might well abdicate (which until then he had refused to do), helping to restore a long-lost tranquillity to the sharifian empire. Then in a calm and orderly manner and without any pressure from any quarter the Moroccan people would choose their own sovereign according to the 'customary procedures' (les usages habituels). ${ }^{46}$

As for Moulay Ben Arafa, who Lemaigre Dubreuil always saluted as a 'noble old man' performing his task with 'perfect dignity,' it was abundantly clear after one year that 'a very large majority' of the Moroccan people refused to recognize him as their sultan. The evidence to the contrary - petitions, demonstrations, and the like in his favor - only proved to Lemaigre Dubreuil just how well organized the protectorate administration really was. Be that as it may, his tenure as sultan could not continue and Lemaigre Dubreuil recommended an 'appropriate retirement' and some 'provisional arrangement' until a 'definitive sovereign' could be named. ${ }^{47}$

The final matter was Lemaigre Dubreuil's personal bête noire: the constant complaint by Frenchmen that there were no 'valid' Moroccan spokesmen. This was nonsense, although he admitted that there were very few of them. 'If the question of the sultanate is discussed,' he predicted, 'true and valid spokesmen (interlocuteurs) will easily be found.' It was to them that the French government should make an official, unambiguous declaration of Moroccan sovereignty. Only then in an atmosphere of absolute and total confidence could joint FrancoMoroccan committees get to work on the reforms that were required. He ended by reminding his readers that in Morocco as elsewhere France had a mission to fulfill: 'Let's get down to business.' 48

On 5 September, Lemaigre Dubreuil met with Premier Mendès France at Marly to talk about Morocco. Lemaigre Dubreuil's bold and insistent writings in Le Monde (especially his recent 'Vérités sur le Maroc'), his personal contacts and even close friendships with individuals on all sides of the Morocco debate, and his tireless activities in favor of a Franco-Moroccan dialogue surely recommended him to the premier. In addition, his determination to find a peaceful solution to the Moroccan problem backed up by the important capital investment of Lesieur-Afrique in the protectorate set him apart from other Frenchmen as tenacious, articulate, and committed as he. Finally, his allegiance to France and its empire, including his wartime resistance in North Africa, although still scoffed at by some Communists and Gaullists, were in truth beyond reproach. The outcome of that meeting was his promise to provide the premier with a report and policy recommendations based on conversations and discussions that he planned to have with 'numerous' Frenchmen and Moroccans from very different 
political and social groups during an upcoming stay in Morocco. That document would be ready in early October.

Predictably 'Vérités sur le Maroc' evoked diverse reactions. Tunisia's Resident General, General Pierre Boyer de Latour du Moulin, who had served as secretarygeneral of political and military affairs in Morocco in 1951, acknowledged that Lemaigre Dubreuil understood the problem and that his article was 'filled with sound ideas.' But he disagreed on the matter of the sultan or, as he put it, the 'dynastic question.' 'It is both too late and too soon to reverse ourselves on this issue,' he insisted, at least until it was certain 'exactly where' the abandonment of Moulay Ben Arafa would lead. To prove the point, he confided that he had his hands full dealing with the ramifications of Mendès France's declaration of internal autonomy for Tunisia. Every concession had been exploited by France's 'adversaries' quickly, cleverly, and even with the threat of insurrection, causing Boyer de Latour 'the most serious concerns' and in truth 'a kind of disgust' (une sorte d'écoeurement). Even 'internal autonomy' was already being dismissed as 'outmoded' with 'total independence' the only acceptable end-point. Given all this, the 'stiffening of our position in Morocco' in his view had become 'an imperious necessity.' 49

Lemaigre Dubreuil responded that while he sympathized with Boyer de Latour's concerns, his own conclusions were quite different, at least for Morocco where things were not the same as in Tunisia. One fact dominated all else: France was bound by countless agreements, including the Pacific Charter (signed in Manila two days before on 8 September 1954), 'to uphold the principle of equal rights and self-determination of peoples' and 'to promote self-government and to secure the independence of all countries whose peoples desire it and are able to undertake its responsibilities.' How then could France pursue 'a totally opposite policy' in North Africa? The unhappy result would be to take on both the East and the West. Moreover, as he saw it, the era of the 'military or police domination' of Morocco and Tunisia was clearly 'over.' And the indigenous nationalism that inspired the struggle against it was in fact a product of French unity, French order, and French education. In the end, there was little that one could do to stave off 'total independence' since it would have to be granted either 'today or tomorrow.' But there were many things that could be done, especially in the economic and cultural fields, by handling each colonial case with care. And Lemaigre Dubreuil was convinced that once Moroccans were certain of France's commitment to their emancipation, they would call on Frenchmen to assist them in every area of their national life. 'In the past it was surely easier and more comfortable for us to deal with everything in our own way protected by treaties that we interpreted ourselves. The often unconscious alliance of the military and top-level administrators - the builders of Morocco - with the colonists who were making money on all sides, and with everyone working for a common goal ... had its raison d'être. But this time is over. Now the task is quite different. Force must give way to understanding.' Finally, what good would it do to delay independence, if by waiting it only caused more suffering, more hatred, more division $?^{50}$

Lemaigre Dubreuil's report to Mendès France surveyed the current state of 


\section{The assassination of Jacques Lemaigre Dubreuil}

Morocco and outlined his recommendations for action. On terrorism he sent along a chart supplied by Major Sartout of Maroc-Presse, which made it clear that in the year since the sultan's exile the pace of terrorism had increased except for three brief periods when Moroccans had hoped for a 'return' to the dialogue with France and a change in the policy of the Residency. Terrorism itself seemed an expression of a 'collective state of mind' rather than the result of decisions made and orders carried out by highly organized terrorist groups. And to end it might not require police work but the cooperation of 'valid nationalist elements.' Over the previous three months and pushed insistently by Istiqlal, the 'dynastic question' had emerged as the most important issue for 'all thinking Moroccans.' It dominated the cities and the tribes closest to the cities, surely a good half of the Moroccan population, and, if canvassed, the vast majority of these Moroccans would express a preference for Mohammed Ben Youssef as their sultan. The other half - the people of the plains, the mountains, and the desert fringes - was tagged as indifferent to the choice of a sultan. In any event, Moulay Ben Arafa's major support, scattered among pashas, caïds, and Makhzen administrators was so insignificant in both numbers and enthusiasm that Lemaigre Dubreuil ventured that his departure from the scene would create 'no serious incident.' A 'possible solution' was the 'voluntary and simultaneous withdrawal' of both sovereigns, leaving the sharifian throne temporarily empty and under the protection of a Regency Council. ${ }^{51}$

The Regency Council plan opened the way to end the Franco-Moroccan crisis, overhaul the sharifian state, and abolish the protectorate. France would immediately confirm the principle of Moroccan sovereignty, pledging to help create the new regime that would make it real. During the period of transition a small but energized Council of Vizirs would administer the country, overseeing the restoration of the freedoms of speech, opinion, the press, assembly, and association and guiding against a return to police or administrative arbitrariness. A provisional Consultative Council (or enlarged Makhzen) would represent Moroccan opinion during the passage to an electoral regime, designating, for example, the Moroccan members of a mixed Franco-Moroccan Commission (or Conseil d'Études des Réformes Institutionnelles) which under the chairmanship of the resident general would start the 'careful and methodical work' of examining a host of common Franco-Moroccan problems. Finally, a new administrative and electoral system based on geography (and in which the pashas and caïds were simple agents of the executive) would replace the tribal organization of the Makhzen and protectorate past. All this amounted to a Moroccan revolution, but one in which France still might play a powerful and creative hand. ${ }^{52}$

Everything was open to negotiation, but to begin with the French government had to be willing to speak abdication to the two sultans. This was somewhat difficult for Mendès France. The premier had publicly acknowledged in the National Assembly (to Lemaigre Dubreuil's dismay) that France would work closely on matters of reform with Moulay Ben Arafa; he had no desire to go back on his words nor to coax Mohammed Ben Youssef into an expensive renunciation. Yet Lemaigre Dubreuil was convinced that at this juncture the former sultan held all the cards and that time was on his side. In fact, unless the premier acted quickly 
he believed that France would soon be forced to accept 'the most humiliating and dangerous conditions' for the French future in Morocco and throughout Africa. ${ }^{53}$

Lemaigre Dubreuil told Mendès France that he remained puzzled at Lacoste's silence on the sultanate, since everyone he had spoken with in the preparation of his report acknowledged this to be the most pressing issue. Was the resident being misinformed by his entourage? Were 'valid Moroccan spokesmen' from both political camps consulting with him? Were Frenchmen obstructing his information flow and his access to Moroccans for their own political ends? He had no idea. But he warned against an 'excess of subtlety' in the resident's statements which had the effect of angering all sides. And he stressed that the moment for action was now, since everything was focused on the dynasty and this, paradoxically, might actually be a blessing. If a 'formula' could be found to resolve the sultanate issue, then with 'new men' and a new policy France could recover from the political mistakes of the past two years, preserving more than just a scrap of its dignity. ${ }^{54}$

Lemaigre Dubreuil emphasized that Mendès France was the man and the hope that Morocco needed and who, rightly or wrongly, Moroccans considered the only statesman capable of righting the wrongs of the past and bringing them 'peace, calm, order, [and] work.' The intellectuals, he noted, had watched him from afar, commenting favorably on his action, his commitment, and his willingness to take on tough tasks. 'They quiver at the thought that they will lose you before you can solve the Moroccan question.' And even though there were risks in every course of action, Lemaigre Dubreuil told the premier that he was certain that to do nothing would surely provoke a 'tragedy' in Morocco 'in a very short period of time.' 55

He recommended what he called a 'middle solution,' sending a small delegation headed by the sultan's physician, Dr. Henri Dubois-Roquebert, to Madagascar to obtain Mohammed Ben Youssef's abdication in favor of a Regency Council. The Council, chaired by the sultan's brother, Moulay Hassan, would include former Grand Vizir Mohammed El Mokri, former Minister of Protocol Si Mohammed Mammeri, the Caliph of Tetouan, and two members of the Conseil Supérieur des Oulémas, so that by its very composition it would symbolize the spiritual and territorial unity of the sharfian empire. The sultan would be relocated in France and not allowed to return to Morocco for five years (unless the oulémas expressly invited him to come back); he would be expected to collaborate 'loyally and officially' with the French government as an adviser on both Muslim and Moroccan matters; and he would have to agree to separate himself from his oldest son, Moulay Hassan, for ten months each year, presumably dampening the political synergy between the two. ${ }^{56}$

With the two abdications in hand - for the withdrawal of Moulay Ben Arafa, who was eager to retire to Tangier, posed no problem - Mendès France might then 'in a spectacular way' read the declarations of the two sultans at Rabat producing the 'necessary psychological shock.' At the same time the premier would explain the Regency Council, announce the Franco-Moroccan Commission, and describe the transformation of the Makhzen. A radio statement by Mohammed Ben Youssef from France and a film of him reading his abdication text would provide Moroccans the proof they needed that their former sultan was not acting under duress. 
As for the dwindling partisans of Ben Arafa, Lemaigre Dubreuil had been told by Moroccans in-the-know that the time was nearing for some sort of reconciliation 'among groups that were totally opposed.' And for the die-hard Frenchmen, perhaps the presence of Marshal Alphonse Juin, the éminence grise of the Moroccan lobby, at the premier's side once again - repeating their performance at Tunis - would suffice. ${ }^{57}$

Despite Lacoste's opposition to the Lemaigre Dubreuil plan, Mendès France sent Dubois-Roquebert to Madagascar but Mohammed Ben Youssef flatly refused the double abdication scheme. Although there was still some hope that, if not a Regency Council, a 'third man' (another member of the sharifian family or even the Caliph of Tetouan) might solve the throne issue - which was apparently Lacoste's view and even Mendès France's preference - the sultan's intransigence was a roadblock to any quick settlement. For his part, Lemaigre Dubreuil continued to write. In mid-October in Le Monde he expressed his concern over the use of brute force employed by the French police, stressing that Frenchmen should recognize that 'the conquest of souls' alone would win over the Moroccan population and thus preserve their own situation and influence. And that Moroccan terrorism had, alas, become 'the only possible expression' for a discontent that was ready to explode, the sad result of France's 'incapacity' to allow the protectorate to evolve. Once the dynastic issue was solved and Moroccan sovereignty proclaimed, he ventured that the odious acts of terror would lose their rationale and Moroccans themselves would put them down. ${ }^{58}$

At the end of the month and even knowing that Mohammed Ben Youssef would not abdicate, Lemaigre Dubreuil could sound a positive note, suggesting that the political immobility of which he complained so bitterly might soon be at an end. Popular wisdom had it that now that Mendès France had dealt with three of the four problems that had faced him at the start of his ministry - Indochina, Tunisia, and German rearmament - it was finally Morocco's turn. To open the discussion he chose to comment on the 'election' of Sultan Moulay Ben Arafa, chosen not by the Moroccan people but by the 'feudal lords' (féodaux) of the regime in a process 'necessary and natural' for the distant past, but hardly acceptable in the modern world and certainly not after 40 years of French tutelage. Was it any surprise that Moroccans themselves, following in French footsteps, protested the events of August 1953 with references to the 'Declaration of the Rights of Man and of the Citizen?'59

What Morocco needed were institutions that would permit public opinion to express itself 'in order, clarity, and complete freedom.' And, if, on the way to that goal, the dynastic issue was revisited, what would be the harm in that? In any event, new institutions required study, prolonged debate, and perhaps 'some years of work' before they could be put into place. During this process, Moroccans should have no option denied them and this included the return of Mohammed Ben Youssef as sultan. Therefore, Lemaigre Dubreuil saw no difficulty, no humiliation, no contradiction - as Resident General Lacoste apparently did - in Frenchmen working with Moroccans to establish a 'provisional government' and representative Moroccan assemblies that might bring the former sultan back to Rabat. 
'A little imagination, much good faith, much love, and great reciprocal confidence based on deeds and not promises, and everything will fall into place ...'60

On the evening that 'Éclaircie sur le Maroc' appeared in Le Monde, Lemaigre Dubreuil had invited Marshal and Madame Juin and the Pasha of Marrakech and his son, Abdessadek al-Glawi, president of the Tribunal Chérifien of Marrakech and a known political liberal, to dine with him in his Paris apartment on rue Émile-Ménier. Before dinner Sadek told Lemaigre Dubreuil that he had read his father the article in Le Monde. It tallied with other things that the pasha had been hearing in the last several days and had contributed to putting him in a state of 'extreme nervousness.' After dinner when the conversation turned to matters Moroccan, the pasha admitted that the current Moroccan policy was a failure but blamed the failure on successive residents general and their 'liberal' attitudes. Still, he had no objection to a policy shift that had as its consequence the "voluntary' departure of Moulay Ben Arafa. On the other hand, he would not accept the return of Mohammed Ben Youssef. ${ }^{61}$

Lemaigre Dubreuil concluded that the pasha - but not the marshal - was very close to a 'healthy understanding' of the situation. And yet by discussion's end because of the marshal's interruptions and digressions, he had been unable to discover exactly what the pasha thought about a successor to Ben Arafa. On leaving the apartment, however, the pasha kissed Lemaigre Dubreuil on both cheeks. 'For a Moroccan perfectly aware of my political position, it is an indication of something. This gesture seemed to me more valuable than the entire conversation.' 62

Adjusting his policy proposals to fit changing political realities, Lemaigre Dubreuil published a summary of his updated views in the confident and overly optimistic 'How to Solve the Moroccan Problem.' It appeared in three installments in Combat in early November only days after anti-French violence erupted throughout Algeria. He continued to believe - and in this he was quite correct that he still remained a bridge between diverse individuals and groups on Moroccan issues. And in fact, over time his words and attitudes, always rooted in the inescapable and brutal facts of the moment, had taken on a decidedly Lyautey flavor to emphasize the bold, the human, the rational, and the just - and at times, the wildly unconventional. This was especially appropriate in November 1954 when the protectorate celebrated the one-hundredth anniversary of Lyautey's birth (and the Moroccan P.T.T. issued four commemorative postage stamps). In Combat Lemaigre Dubreuil announced that if this were not the very best of times to start a difficult negotiation on Morocco, it still might be the 'least bad.' He began with an overview of the issues and the specific problems they presented. ${ }^{63}$

The 'dynastic question' had to be settled before any discussion or any action on the Franco-Moroccan future could take place and this could only happen after a provisional Moroccan government had been named, consisting of a Regency Council 'guardian of the throne' (which Lemaigre Dubreuil considered far superior to the 'third man' solution to the sultanate) and an 'expanded government' (gouvernement élargi) replacing the present Makhzen, charged with the administration of the country and vested with 'defined powers.' The new government would then designate the members of a Franco-Moroccan Commission, to be 
chaired by the resident general assisted by French experts, that would determine how Moroccan public opinion could best express itself 'freely and authentically' (librement et valablement). And from this inquiry would come the procedure to designate the next sultan. To enable all this to succeed, of course, required Moroccans to put partisanship aside and think more of Morocco than of themselves. ${ }^{64}$

For France the need was to demonstrate a real change in its Morocco policy by appointing a 'new team,' by annulling all legislation that failed to respect Moroccan sovereignty, and by displaying great 'good faith' in all FrancoMoroccan negotiations. In addition and importantly, France had to convince the pasha of Marrakech, this 'constant and faithful friend of France,' to accept its new policy. But Lemaigre Dubreuil did not doubt for a moment that, as in the past, the pasha would stand at France's side, for in truth, his current politics were little more than the translation of the 'often unavowed' desires of the protectorate administration and the French government. On the other hand, it would be more difficult to convince individual Frenchmen, including top protectorate administrators, even though they were surely aware of the failure of the policy of force, to cross the Rubicon and adopt a new policy. ${ }^{65}$

Lemaigre Dubreuil insisted that the move toward the 'progressive independence' of Morocco take place in order, peace, and security. France would certainly not be summarily and completely evicted from Morocco despite nationalist threats and French fears. The administration of the country, for example, would only be turned over 'in stages' to its new landlords. And emancipation would halt if it ever became 'a factor of trouble and conflict.' Terrorism, which Lemaigre Dubreuil called 'the only possible and visible reaction against our policy,' was at its origin Istiqlal's responsibility, yet both religion - the power of Islam - and communism played a part in its advance. 'We must accept the fact that all the countries of North Africa represent to Russia immense unsinkable battleships with their guns trained on Asia, whereas their storerooms remain open to the Americas, Europe, and Africa.' Disorder in North Africa was, therefore, an 'imperative' of the communist strategy. And so once calm returned to Morocco, more than ever would France need to reinforce its military presence in the Maghreb, strengthened, to be sure, by a renewed Moroccan commitment both to France and the West. ${ }^{66}$

Finally, what of France itself or what Lemaigre Dubreuil called the 'instability' of our governments? Although this political disarray was a 'serious handicap,' Lemaigre Dubreuil chalked it up as the 'ransom for our freedom,' the very liberty that Moroccans now sought so intently. France needed to explain all this to them, to convince them of 'our difficulties.' But freedom was always a work in progress and he guessed that it would take Morocco 'five years of political continuity' to regain its balance and fashion the first steps of its freedom. It was somewhat ironic, he thought, that France, branded as a backward colonial power by friends and foes alike, could soon be engaged in constructing a modern constitutional monarchy in the Maghreb based on the fullest possible public consultation. But in carrying out this mission, as Mendès France had already twice demonstrated, France would again show the rest of the world how to do things. ${ }^{67}$

In an unprecedented effort to gain support for his plan as well as to gauge public 
sentiment in Morocco, Lemaigre Dubreuil circulated a reprint of the Combat article together with a questionnaire (dated 22 November 1954) among prominent Moroccans and Frenchmen asking for their input. He chose 35 Frenchmen who had 'reflected' on the problem of Franco-Moroccan 'co-existence' and on the mission of France in Morocco. ${ }^{68}$ The 29 Moroccans were similarly committed to a positive Franco-Moroccan future; and with these individual answers were included the collective replies of the governing boards of Istiqlal and the Parti Démocratique de l'Indépendance as well as of the officers of Moroccan student organizations both in France and in Morocco. After the responses were tallied in early December Lemaigre Dubreuil offered each respondent a synthesis of the information that had been gathered. He also shared this compilation (and some of the more important individual responses) with members of the French government and discussed it in detail with the participants in his Morocco study group. Although his data base was small, these thoughtful and always provocative essays provided a rich source of renewed inspiration for him and new direction for his own writing.

What did they reveal? To no one's surprise that the Moroccan situation was getting worse - the political troubles were fast spreading from the cities.into the countryside and the economic crisis was becoming ever more serious. Still, there seemed to be a temporary 'pause' based on equal parts of hope for action from the Mendès France government and of fear for things deteriorating even more. And this pause might signal a 'favorable climate' when the mutual good will between Frenchmen and Moroccans could be used to promote 'acceptable solutions' to the crisis. ${ }^{69}$

The agreed-upon cause of the crisis was the desire of Moroccans to achieve their independence. For the majority of Moroccans this was an emotional issue rooted in legitimate individual and national pride that was wounded on a daily basis by numerous displays of dependence. The greatest symbol of this dependence was the deposition of Mohammed Ben Youssef which, had it been followed by a declaration of internal autonomy, might have been interpreted in an entirely different light. Moreover, for educated Moroccans it was a humiliation that 'less mature' (moins évolués) Arab countries were independent and that France had agreed to or was considering internal autonomy statutes for places like Togo or the Cameroons in Black Africa. Yet nothing had been done for Morocco. For many Moroccans, independence was both emotional and material for they were convinced that the time had come to run their country and its national economy, serving both and benefitting from both, and Mohammed Ben Youssef was a symbol of and the 'only qualified spokesman' for their frustrated aspirations. ${ }^{70}$

To find some common ground between Frenchmen and Moroccans (and other minorities in Morocco), the respondents agreed that the French government had first to define France's role, the legitimate rights of Moroccans, and the rights of France and Frenchmen in Morocco. Beyond this, Moroccans asked for internal autonomy but only as a step on a well-defined path toward complete independence. In addition, the dynastic issue had to be resolved immediately and although the Regency Council was a possible solution, it could only happen with the assent of 
Mohammed Ben Youssef. On the other hand, a Moroccan provisional government seemed 'premature' to many and risked complicating the political situation, since without a written constitution guiding the composition of such a government, it might well be considered 'imposed by France and worthless.' Besides, how could such a government, installed before any declaration (or precise definition) of internal autonomy or of the exact stages to be followed toward independence had been made, preserve both its authority and its prestige to negotiate with France at each successive step? Finally, any agreement (or series of agreements) between a provisional government and France before the resolution of the dynastic question might well be undone after that issue had been settled. In sum, the respondents believed that it was preferable to begin with a Regency Council (and perhaps with a 'broadened' Makhzen) that would have as their most important tasks the writing of a constitution, updating the rules for choosing a sultan and presiding over his selection, and, finally, working with a Franco-Moroccan consultative committee to prepare a series of Franco-Moroccan agreements. ${ }^{71}$

Although the responses of Istiqlal and the Parti Démocratique de l'Indépendance were incorporated in the general summary, Istiqlal did insist that for the Moroccan people Mohammed Ben Youssef remained 'the only legitimate sovereign.' Yet to move beyond the current impasse, Istiqlal supported Lemaigre Dubreuil's 'provisional solution' - which was really only the 'beginning of a solution' - designed to bring about a period of calm and détente, conditions essential to dealing with serious political problems. Nevertheless, it was 'indispensable' that all the members of any Regency Council be approved by Mohammed Ben Youssef. And that this Council alone choose the members of any provisional Moroccan government whose mission would be to negotiate 'a new definition of Franco-Moroccan relations' and to do whatever was necessary to establish a constitutional monarchy. Istiqlal also urged a declaration of Moroccan sovereignty from the French government, coupled with a promise to permit the full exercise of that sovereignty; the immediate transfer of Mohammed Ben Youssef from Madagascar to France; the lifting of the state of siege, the liberation of all political prisoners, and the guarantee of personal liberties for all Moroccans. The Parti Démocratique de l'Indépendance acknowledged that Lemaigre Dubreuil's proposals were 'interesting and constructive' and that in general it was urgent to find a solution to the crisis in Franco-Morocco relations. But it refused to mention the Regency Council by name, merely noting that Mohammed Ben Youssef's return to the throne was the precondition for the creation of any provisional government. ${ }^{72}$

Although there was near-unanimous agreement on the usefulness of a Regency Council (if not on its shape, composition, or authority) among those who answered the questionnaire, this possibility was apparently squelched when Minister of Foreign Affairs Georges Bidault responded to a query in the Chamber of Deputies by saying that the French government had no intention of changing the present sultan of Morocco. Nevertheless, Lemaigre Dubreuil continued to hammer away for some resolution of the 'throne question' for fear that if nothing were done, Morocco's current 'illness' might become 'fatal.' And France itself was 
responsible for the present situation which was 'the terrible culmination' - in the end calling forth 'a sort of holy war' in Morocco - of a policy that had been nothing but a 'fabric of errors and contradictions.' It was therefore imperative, he pleaded, for France finally to show its true face, giving 'new confidence' to the immense majority of Moroccans who remained devoted to France. ${ }^{73}$

At the end of December Lemaigre Dubreuil reflected on the Moroccan crisis for the readers of Combat, already familiar with his November proposal on how to solve it. He started at the beginning with the Treaty of Fez and the 'considerable powers' of the resident general - the 'real absolute monarch' of Morocco - who by delegating authority to French administrators across the country had created thousands of small 'kinglets' (roitelets). Over time a system of direct (instead of the much-vaunted indirect) rule triumphed, bringing with it a concentration of executive, legislative, and judicial powers that would make Montesquieu spin in his grave. The system had its advantages: the 'remarkable and particularly rapid' material progress of the country - gesta dei per Francos - and the consequent advances in all areas of social and economic life. It failed, however, to prepare Moroccans 'intellectually' to take charge of their own destiny. Nevertheless, an alert Moroccan public, increasingly aware of the world and Morocco's place in it, rejected its role as the citizenry of a 'vassal state.' And from this wounded pride arose the national political opposition to the protectorate regime with the sultan at the head of the 'resistance.' 74

The French response, decided by soldier-administrators in Rabat but approved by political leaders in Paris, was 'brutal' - the sultan deposed, Istiqlal dissolved, thousands of 'suspects' arrested. In short, to stop the protest of those who feared for the loss of their personal and civic liberties, the protectorate simply took them away. Now silenced, the opposition went underground and acts of terror replaced public meetings, protest marches, open discourse, and the printed word. The sultan in exile became a martyr and a symbol for a large part of the Moroccan population of its own 'powerlessness.' 75

To document how serious the crisis had become and how important the need for 'lasting solutions' (remèdes définitifs) rather than quick fixes, Lemaigre Dubreuil offered four observations. First, the terrorists were not professional killers but artisans and merchants (artisans, commerçants) acting out of patriotic or religious conviction. Second, Sultan Moulay Ben Arafa's unpopularity was a political reality about which the protectorate administration could do little, 'for in today's world popularity cannot be imposed, it must be acquired.' Third, at the recent ceremonies to honor Marshal Lyautey only those Moroccans whose public responsibilities required them to be present were in attendance. Every other Moroccan stayed away. Yet less than two years before, a large Moroccan crowd had followed the funeral cortege of Madame Lyautey to the grounds of the residency. Fourth, in stark contrast to the Lyautey slight, almost 20,000 Moroccans had accompanied the body of Maître Omar Slaoui of Casablanca, a lawyer at the pasha's tribunal, murdered by counter-terrorists at the end of August. ${ }^{76}$

Lemaigre Dubreuil concluded that the estrangement between the protectors and the protected was real and deep. And that it was urgent for France to work for 
reconciliation both for the good of Morocco and for the safeguard of its own interests which could only be preserved through covenants freely arrived at between the two peoples. For Morocco reconciliation could mean access to French, inter-European, and international credit, vital for its transformation into a truly sovereign state. And here he left no doubt that Moroccan independence was just a matter of time for Tunisia, Algeria, and Morocco were the only Arab nations on the planet not yet independent - and timing, as always, was of the essence. ${ }^{77}$

How should this reconciliation be accomplished? After a litany of failed and half-hearted efforts Lemaigre Dubreuil urged the French government once and for all to state its position and then to act on it decisively. The first question to solve was that of the throne for its resolution alone would produce the changed atmosphere without which no policy could succeed. And in this matter France must take the role of arbiter rather than that of active participant. A provisional Moroccan 'regime' comprised of 'acceptable individuals' (hommes valables) designated by the 'diverse political groups' (diverses tendances) working together with the resident general (and assisted by French advisers) would begin the task of sorting out the issues raised by the new French policy. At the same time they would determine the procedures to follow in the designation of a new sovereign. Gone from this proposal were the specific references to a provisional Moroccan government or to a Regency Council or to an 'expanded Makhzen' or to a Franco-Moroccan Commission on Reforms. But they still existed, albeit untagged, in this streamlined version of his Moroccan plan. What Moroccan or Frenchman of good faith, he asked, could oppose such a design? For solving the Moroccan situation was nothing more than a simple matter of 'imagination, will, and humanity.' 78

Unfortunately the terrorist and counter-terrorist assaults continued without letup. On 4 January in Casablanca Antoine Turiel, professor of Spanish at the Lycée Lyautey, and Émile Desprades were both 'seriously wounded' by gunshots; and the following day office worker Baptiste Peralta was killed in the nouvelle médina on his way to work. For Lemaigre Dubreuil, however, the assassination of Si Tahar Sebti, machine-gunned in Casablanca on 2 January by counter-terrorists as he arrived at the office of his family's textile firm, was a serious personal blow. Sebti was a director of Lesieur-Afrique, a member of a well-known and influential Fassi family, and a participant in Lemaigre Dubreuil's study group. He was young, married, the father of two small children; he had studied at a French lycée in Fez and had spent two years in Paris. He was just the sort of young Moroccan who Lemaigre Dubreuil counted on to keep the Franco-Moroccan connection alive. A 'brilliant and thoughtful' man, Sebti was a 'convinced nationalist' who wanted Morocco to link itself 'freely' to France. In fact, it was as a result of this contact with France, so Lemaigre Dubreuil argued, that Sebti became so filled with idealism and notions of liberty. By a 'tragic contradiction' he died because of them. ${ }^{79}$ Lemaigre Dubreuil's grief was palpable.

In a turn to the unsettling parallels with France during the 'dark years' of the German occupation - and perhaps even remembering Mauriac's 'Vocation des chrétiens' that had so infuriated him two years before - Lemaigre Dubreuil recounted the tales of 'honorable and well-to-do' Moroccans to readers of Le 
Monde. These middle-class folk had been roused from bed in the dead of night by insistent raps on the door; confronted by stern, uniformed policemen; ordered to dress hurriedly (while frantically trying to make phone calls to police headquarters to verify the identity of the officers); then bundled off to the local police station to deal with some matter of insignificance. It was a pattern all so familiar to Frenchmen that he did not need to explain the emotions involved nor the point of the charade. But many Moroccans, caught between terrorism and counterterrorism, now lived in this state of 'constant anxiety' for their freedom and for their safety. Some had even fled the country. 'Today's anxiety,' warned Lemaigre Dubreuil, 'will engender the hatred of tomorrow.' It all seemed so unnecessary, a throwback to some terrible and unhappy French past. And it was precisely these methods in Morocco, not the legitimate and durable interests of France and Frenchmen, that were at issue. What was to be done? As ever, Lemaigre Dubreuil called for 'new methods.' But, first, the parliament and the rest of the country had to know this 'truth' about the role of France 'overseas' (les pays d'outre-mer). ${ }^{80}$

He predicted that in the post-atomic world, now strode in colossus by two dominant power 'blocs,' the next 'terrible offensive' would come from the 'weak of the earth' - the peoples of North Africa, for example - over whom both of the blocs wished to extend their political and economic hegemony. Since each bloc was in tight competition with one another, was it really imaginable that the interests of Frenchmen in North Africa would be allowed to spoil the appeal of the 'fundamental policies' of the Western bloc? Or that the 'colonial situation' with its policy of force was still possible in the modern world? Or that anarchy, as produced by the terrorism and counter-terrorism of Morocco, could not push Moroccans toward 'another form of civilization' and the Eastern bloc? All this, so much of which was speculation of the Orwellian sort, Lemaigre Dubreuil hoped would give pause to both Frenchmen and Moroccans, causing them to remember that the connections between France and Morocco would extend far into the future. If they continued in harmony with the transformations of the world, then any difficulties would surely disappear. If not, then failure and chaos would result. ${ }^{81}$

Mendès France lost the confidence of the Chamber of Deputies in February and resigned as premier. It was a victory for the hard-liners in Rabat and Paris and Lemaigre Dubreuil was understandably disappointed, but not discouraged. He told a confidant in Tunis that no one could imagine the 'baseness' of the action of the members of parliament, the hoots and the catcalls at the moment of the premier's departure from the chamber, mainly from the deputies on the Right. Or the 'mediocrity' of the political dealings and the 'sordid [political] discussions' presently taking place. To his credit, 'Mendès pulled the country out of its stagnation (immobilisme) and, in my view, that is the great service that he rendered us.' Of course, he added, no one in his own social set thought so, but he tried his best to limit the time spent at 'bourgeois dinner parties or social gatherings.' 82

Paris disappeared from the political charts for eighteen days until Edgar Faure finally surfaced as Mendès France's successor at the end of February, cheered by Rabat as a herald of a return to government at tortoise pace, at least until the next 


\section{The assassination of Jacques Lemaigre Dubreuil}

legislative elections. On the other hand, Lemaigre Dubreuil launched a new and spectacular initiative, one that he hoped would produce a political breakthrough that government action (or inaction) alone had so far failed to achieve. He purchased a majority interest in the Casablanca daily newspaper, MarocPresse, intent on keeping it a liberal trumpet, committed to Franco-Moroccan reconciliation. But before finalizing the deal, he met with Premier Faure (less than a week after he had taken office) and with Minister of Tunisian and Moroccan Affairs Pierre July, telling them that he would only go forward if he were convinced that the government would energetically support a policy of dialogue and understanding, repudiating force as an instrument of policy. Sure that he had such a promise, he negotiated the sale in April 1955 from Jacques Walter, an industrialist whose father had made a fortune in Moroccan lead and zinc, and named his son-in-law, Baudouin de Moustier, the président directeur général of Publications-Élysées, to the post of president of the board of directors and publication director of Maroc-Presse. ${ }^{83}$

Although Lemaigre Dubreuil had some experience with newspaper ownership with the hatchet-wielding L'Action contribuable and the bellicose Le Jour-Écho de Paris - Maroc-Presse, like those previous enterprises, was never bright with money-making promise nor was it intended to be. This was a political venture and a personal statement, following in the footsteps of the newspaper's former political director, Major Henri Sartout, who had begun the Center-Left tack after the sultan's exile. Lemaigre Dubreuil preferred to dub the newspaper's politics that of the 'new Right' (nouvelle droite) - to echo Mendès France's 'new Left' - and he suggested that his acquisition of Maroc-Presse would be just the first step in a 'vast operation' to 'simplify' the politics of the French press in Morocco. To start off Maroc-Presse would take as its special task the role of mediator between the spokesmen for Moroccan nationalism and the representatives of the French business community. ${ }^{84}$

Lemaigre Dubreuil admired Sartout. The major was a committed member of his study group and for months he had provided Lemaigre Dubreuil with political data and information of all sorts. He was a reasonable and objective man who over time had become a convinced liberal and in print was somewhat fearless. It was he who educated Lemaigre Dubreuil in the true nature of Moroccan terrorism - random, patriotic, and increasingly justified by police abuses and brutalities and the suspension of personal liberties - and showed him the real face of European counter-terrorism, an organized murder operation that targeted and tracked specific Moroccans and Frenchmen. In fact, it was counter-terrorism that bound the two men ever more closely together and in the end - although this was quite politically incorrect - it outraged them more than terrorism itself. They worked to unmask the Frenchmen behind it, to expose their deadly anti-French activities to the Metropole and to the French government. By so doing they sought to discredit them and force the government (or the Residency) to act against them. Most important, they hoped to crack the power of the Moroccan lobby, the business-political-military complex that was the great roadblock to progressive reform and of which counter-terrorism was the ugly appendage. 
Sartout stumbled in a front-page Maroc-Presse 'European terrorism' editorial on 4 February 1955 by openly accusing Frenchmen in Casablanca of being responsible for some of the attacks on Moroccans and 'even against Frenchmen.' Most Frenchmen were indignant; the Residency warned Maroc-Presse against any such outbursts in the future and assigned armed policemen to protect the newspaper's offices and presses; and Sartout was forced to cool his heels at home for a time. The end result of the 'scandal' may have been to persuade the Walters, both father (now in retirement in France and an important art collector) and son, to seek a way out of their newspaper commitment as fast as possible, although in the final settlement the Walters did retain one-third of the voting stock in the parent company. Under Lemaigre Dubreuil Sartout would remain on the editorial board of Maroc-Presse but no longer in charge of its day-to-day political direction. ${ }^{85}$

It was Sebti's gangland-style murder that fired Lemaigre Dubreuil's anger against counter-terrorism and pushed him forward with Maroc-Presse. But the death of Police Inspector Albert Forestier, a youthful protégé of Sartout's, was a potent marker for him as well. Forestier was killed in a car accident near Rabat on the night following Sebti's assassination in what Sartout and Lemaigre Dubreuil assumed to be a counter-terrorist ambush. Not suprisingly, the first reports that Lemaigre Dubreuil passed to Premier Faure in mid-March dealt in detail with counter-terrorism and the 'Forestier Affair,' prefaced by a note which defined terrorism (both Moroccan and French) and summarized the statistics on terrorist assaults. In the fifteen months between December 1953 and March 1955 there had been 1222 terrorist (or counter-terrorist) attacks, accounting for 259 deaths and 732 wounded, the majority of which took place in Casablanca, now dubbed 'Morocco's Chicago.' 86

Forestier was born and schooled in Casablanca. The sports writer for MarocPresse identified him at an early age as a talented athlete and followed his career with positive notes in the sports pages; in 1948 he hired him as a cub reporter. The young journalist quickly made friends on the newspaper's staff, including Antoine Mazella, the current editor-in-chief, for whom he developed both affection and respect. To fulfill his military service obligation Forestier enlisted for a three-year tour of duty in Indochina during which time he received an impressive array of citations praising his military qualities - his calm, courage, energy, leadership ability, and 'remarkable coolness' under fire - and his combat exploits. When he returned to Casablanca, there were no jobs available at the offices of Maroc-Presse, so he applied for a position with the police, then rapidly expanding its ranks because of the turmoil in the city's streets. To support his application he received the enthusiastic backing of the local chapter of the Association des Anciens Combattants d'Indochine, whose honorary president was Major Sartout. In short order Forestier was employed as an inspector of police and given assignments which in time led to information gathering and case evaluation on European counter-terrorism. His friendship with the journalists of Maroc-Presse remained close, confident, and professionally valuable. Mazella, for example, attended early secret meetings with Moroccan nationalists where influential members of Présence Française, the organization committed to keeping Morocco French, were present. And in 


\section{The assassination of Jacques Lemaigre Dubreuil}

October 1954 because of his outspoken liberal views on French policy Mazella was the target of a counter-terrorist's bomb. Until Forestier's 'accidental' death, the young police inspector and the Maroc-Presse team continued to discuss counterterrorism and share information with each other. ${ }^{87}$

From the start Forestier's task forced him to act as a double agent, working with and against the hit-men employed to murder important Moroccans and Frenchmen. The dossier that Lemaigre Dubreuil assembled for Faure recounted how Forestier accomplished this and what he learned, but, perhaps as disturbing, it chronicled the lack of active support that Forestier received from his superiors, despite Forestier's and Sartout's repeated interventions with higher-ups in the police, the departments of public security and the interior, and at the Residency..$^{88}$ This refusal to act, which amounted to official complicity in counter-terror, led Lemaigre Dubreuil to conclude that the government's indecision, its lack of will, and its failure to command or to require obedience were responsible for the state of 'anarchy' in Casablanca, which, if not scotched, would soon spread to the rest of the country. 'Morocco is in danger,' he predicted. 'The era of the diplomats' subtle word games (dissociations subtiles des jeux de l'esprit des diplomates) is over. The moment is for action, that is, if our structure of government will allow it.' 89

In his opening statement as the new owner of Maroc-Presse (on 23 April 1955) Lemaigre Dubreuil confided that he had debated whether to run the financial risks of such an enterprise while Morocco continued to be saddled with a French government policy that was 'hesitant or contradictory,' shifting uneasily between a policy of force and a policy of confidence. Only when he had received the government's assurance that it had finally decided to orient its political course toward 'the free expression of both French and Moroccan thought in French newspapers' and after he had received the 'encouragement' - and even the 'formal advice' - of the 'highest government officials' to embark on this project, did he determine to go forward. He understood freedom of expression to be a necessary element of respect for human dignity and a key factor in the search for solutions to Morocco's problems. The 'new formula' for Maroc-Presse - an 'Open Forum' (Tribune libre) that would encourage free expression - would permit the study of Franco-Moroccan relations by listening to diverse French and Moroccan opinions in a serene atmosphere. He pledged to put the management of the newspaper in the hands of 'independent, far-sighted, non-partisan' men, unencumbered by sentiments of 'a narrow nationalism,' yet committed to re-making Morocco..$^{90}$

There was much to be done in this country which, because of the lack of any 'guiding governmental policy' (pensée maitresse gouvernementale), had been made hostage to terrorism and counter-terrorism with its 'odious and deceptive (sournoise) war of anonymous letters, clandestine tracts, and libel.' And in which, after 40 years of education in civic culture - and in complete disregard of Lyautey's lessons - tribes had been set against tribes, the countryside pitted against the city, all in a vain attempt to restore order, 'as if France, abandoning its mission, had neither the force nor the greatness (grandeur) to exercise its own authority fairly, firmly, and swiftly.' In the end, the most important and creative of 
France's accomplishments in Morocco, the very hallmarks of French genius which gave France 'an absolute right to the permanence of its presence here' would collapse in 'frightful chaos,' if 'having conquered Morocco's body, we could not or could no longer capture its soul.' He appealed to Maroc-Presse's readers, its friends, loyal opponents, and especially French and Moroccan youth to 'help us' by writing to the newspaper - 'aidez-nous, écrivez-nous.' 91

He also implored Mendès France (at the moment of the former premier's election as first vice-president of the Radical party, a step on the political comeback trail) to support him on Morocco through his influence, suggesting that perhaps in the future Maroc-Presse might be of use to him. ${ }^{92}$ And in another burst of enthusiasm Lemaigre Dubreuil began to negotiate for the purchase of stock in Le Petit Marocain, not as an attempted take-over, but as part of his hoped-for political re-alignment of the Casablanca press in order to strengthen the call for a firmer, more coherent Moroccan policy.

By most accounts Maroc-Presse's 'Open Forum' was a stunning success. Neither Frenchmen nor Moroccans had seen (or read) anything like it. From the start Moroccans seemed to write more openly and with greater power and insight than many Frenchman had expected. (Lemaigre Dubreuil sent copies of two essays to Mendès France in his letter of 5 May as proof of what was happening.) So did Frenchmen, including Henri, the Count of Paris, who had lived in exile in Morocco for the first fifteen years of his life. Success in Rabat even helped promote a two-day conference in Paris on 7-8 May on the 'Franco-Moroccan problem' - the Conférence nationale pour la solution du problème francomarocain - sponsored by liberals on both sides of the Mediterranean. ${ }^{93}$ But this advance was double-edged since it quickly raised the anti-liberal blade in response. Yet boosted by the positive Maroc-Presse feedback, Lemaigre Dubreuil met with Faure in the second week of June - amidst shop closings in Morocco's medinas (principally Casablanca, Rabat, and Salé) and a fishermen's strike at Safi - hoping to convince the premier to stand firm against a cabinet majority that still seemed to prefer the status quo and to act instead in a decisive and conciliatory way. He may even have suggested that his own life was on the line as he surely knew that it was. The day after this meeting - a summer evening in Casablanca - on leaving his apartment building on the Rond-Point de la Révolution Française in center city a half-hour before midnight, Lemaigre Dubreuil was machine-gunned in a counter-terrorist attack that put thirteen bullets in his back. He died in the ambulance on the way to the Hôpital JulesColombani.

Lemaigre Dubreuil's death changed everything. It forced the government to speak with dramatic conviction and to act with some dispatch. Minister of Tunisian and Moroccan Affairs Pierre July told the press that this 'tragic death' revolted all Frenchmen 'worthy of the name,' suggesting that the counter-terrorists whom he held responsible for it (and by implication those who supported them) were unworthy to be called Frenchmen. This was an extraordinary statement, given that no one had yet been arrested for the crime. He reminded reporters that in his last two trips to Morocco he had warned Frenchmen of the need 'to put an end to their 


\section{The assassination of Jacques Lemaigre Dubreuil}

quarrels' and that two months ago the government had sponsored an inquiry into the organization of the police in Morocco. Yet counter-terrorism had 'once again' dishonored France, finding supporters in both Rabat and Paris. He announced that a special team of the 'most eminent' metropolitan police officials would take charge of the Lemaigre Dubreuil investigation and he promised a permanent remedy this time for the ongoing 'ineffective and deficient' police structure in Rabat. July concluded: 'I hope that this hatred among Frenchmen, kindled at the precise moment that very serious incidents are rocking all of North Africa, has finally come to an end. In any case, let those who are responsible know that this government is firmly committed to taking all the measures necessary to reestablish order and that we will tolerate no weakness.' The editor of Combat, which had printed the full text of July's remarks, added that Frenchmen were revolted but not terrorized. 'Lemaigre Dubreuil was cowardly assassinated. His ideas will triumph.' 94

Maroc-Presse took the initiative by signaling its determination to continue the work of Lemaigre Dubreuil, so 'faithfully committed' to a Morocco that had 'already begun to respond to his call.' 95 Yet it was too soon to have an exact idea of the public reaction to his death. He was killed late Saturday night and on Sunday most Frenchmen were out of the city just as most Moroccans were away from their shops or places of business. The Residency quickly expressed its indignation at the murder of the man who had worked behind the scenes for the appointment of a diplomat as resident general only to be soon disappointed by Lacoste's lack of liberal vigor; Conscience Française, counting Lemaigre Dubreuil as both friend and patron, was understandably 'distressed;' and journalists and newspaper men throughout the city appeared to be 'very much affected' by the news. The few Moroccans whom the Casablanca correspondent for Le Figaro could contact for an instant opinion believed that this was a blow to the 'policy of rapprochement' with the obvious intent of widening the gap between Frenchmen and Moroccans. In fact, from everyone who said anything the reporter detected a 'serious malaise' and a sense of anxiety for the future. ${ }^{96}$ Even the Times (London), relying on its men in Morocco, sounded bleak: 'If terrorism - which on both sides chooses as its target men of moderate opinion - is allowed to continue, conditions in Morocco will degenerate into almost open civil war.'97

From Paris the signs were in the opposite and positive direction, that something terrible but important had happened and that nothing would ever be the same again. The magisterial essay on the assassination and its significance by PierreAlbin Martel, Le Monde's North Africa expert, set the tone for the outraged commentary in the metropolitan press. Martel had no difficulty calling 'counterterrorism' by the unvarnished name of 'French terrorism.' Or suggesting that what its French targets - Sartout and Mazella of Maroc-Presse; Pierre Clostermann, directeur des Établissements Renaudat-Maroc and deputy of the Marne; Jacques Reitzer, administrateur-délégué of the Compagnie Fermière des Eaux d'Oulmès-État; and Lemaigre Dubreuil - all had in common was a commitment to a peaceful resolution of the Moroccan crisis through the 'honorable settlement' of the throne question and the negotiation of a new Franco-Moroccan connection, 
granting full sovereignty to the sharifian state yet providing for Franco-Moroccan inter-dependent links. When 'counter-terrorism' first emerged in February 1954, these Frenchmen denounced it, its perpetrators, and, whenever possible, those who sustained it. 98

Martel revealed that two months before his death Lemaigre Dubreuil had presented a 'very complete report' on counter-terrorism to Premier Faure and Minister of Tunisian and Moroccan Affairs July. It summarized and up-dated information gathered by Sartout, Mazella, and the unfortunate Police Inspector Forestier that had earlier been submitted to top protectorate security officials yet never acted on. Among other things, the report documented 'the more or less direct complicity of certain police officers in several [counter-terrorist] attacks.' Yet, despite the protectorate's earlier evocation of a war on 'two fronts' (in December 1954) and July's stated determination to root out 'all the gangsterisms' in a Casablanca transformed into a 'new Chicago' (in March 1955), there had been no arrests, no indictments, no transfers, no expulsions. Was this because, as July had hinted in his first statement to the press on the assassination, that counter-terrorism had found 'support' (un appui) in Paris?99

To end terrorism and counter-terrorism, so Martel insisted, required a government authority 'sure of itself,' then words from Paris that compelled order and discipline, followed by acts of a stern and swift justice. For without punishment criminals continued on their way with impunity. And this was just the beginning. What Lemaigre Dubreuil's enemies surely had liked least about him was that he was having some success with the government and members of the Moroccan elite in crafting a policy that would offer both Frenchmen and Moroccans 'of good will' - who until then had no real means of public expression open to them a forum through which to search for solutions to the present crisis. This was more necessary now than ever before. And the government needed to take strong action while there was time to preserve what still remained of Franco-Moroccan friendship. ${ }^{100}$

Sharing space with Martel's essay was a detailed report on the assassination by a Le Monde correspondent and a chronicle of the intense political activity at the Hôtel Matignon, including mention of Premier Faure's private visit of condolence to Lemaigre Dubreuil's widow. In addition, there was a striking letter from Charles Celier, an international lawyer with offices in Casablanca and a professor at the Institut d'Études Politiques in Paris, predicting that Frenchmen from Morocco who were sympathetic to Lemaigre Dubreuil's ideas would now redouble their efforts to work for peace, understanding, and friendship. 'By his acts as well as through his pen and his words Lemaigre Dubreuil expressed with éclat a serene faith in France and Morocco and a willingness to move beyond hatreds and misunderstandings in order to construct a better future for everyone.' Finally, the words Le Monde quoted from other Paris newspapers were also without compromise. L'Aurore suggested that French public opinion would be revolted by 'this abominable crime' and Le Figaro anticipated that Moroccans and Frenchmen would share 'a unanimous indignation' at the assassination. Franc-Tireur described counter-terrorism as a sort of 'police state within a state' and editor Jean 


\section{The assassination of Jacques Lemaigre Dubreuil}

Rous noted that while Lemaigre Dubreuil, like all Frenchmen, denounced terrorism, he had considered counter-terrorism something worse, something that was really 'beneath the dignity' of all Frenchmen, the very sentiments that July had evoked from beyond Lemaigre Dubreuil's tomb. ${ }^{101}$

The funeral service for Lemaigre Dubreuil, celebrated on the morning of 14 June in the Église du Sacré-Coeur in Casablanca, mixed genuine emotion, political conviction, and the unhappy irony that all such occasions produce. General Béthouart, one of Lemaigre Dubreuil's co-conspirators in November 1942 and his companion on the Giraud team, was absent among the mourners. Although known as a political moderate, as a candidate of the Mouvement Républicain Populaire (MRP) in the upcoming senate elections and seeking to represent all the Frenchmen of Morocco, he was forced to miss the funeral of his former comrade. And Resident General Lacoste, who knew his own political days were numbered the instant he learned of Lemaigre Dubreuil's murder, could do no more than deplore in a radio address the 'criminal attacks' that had 'almost simultaneously' struck down an important businessman in Casablanca, a French soldier from the Rabat garrison, an old Moroccan man at Berkane, and an officer of the Urban Affairs unit from Marrakech. 'Violence in all its forms is horrible,' he announced, having done precious little to quash counter-terrorism, 'and equally reprehensible and hateful.' 102

A controversial, high-profile mourner was former premier Pierre Mendès France, who arrived in Casablanca the evening prior to the funeral only to be greeted at the airport with threatening cries - 'Traitor!' 'Dirty Jew!' and 'Sell-out!' - from a small unfriendly crowd tipped off to his coming by the media. This was countered by applause from another group of onlookers, followed by something of a 'brouhaha' between folk on opposing sides, a sad measure of the degree of political tension in the French community. Although Mendès France refused to speak to the press because of the private nature of his visit, he did have a political purpose: to demonstrate his solidarity with Lemaigre Dubreuil's liberal stand on matters Moroccan (especially in light of Lemaigre Dubreuil's personal appeal to him at the beginning of May and surely with some regret at not having acted on Morocco while premier) and to participate in a march against counter-terrorism in the streets of Casablanca. Neither was without physical danger and both made him a focus of reporters and a target of hostile Frenchmen. On the morning of the funeral this forced him to enter a side door of the church and to slip unobtrusively into his place in the nave, then to cancel his street walk on the advice of the police, meeting instead privately at the El Mansour Hotel the next day with 'several French and Moroccan personalities.' Having done the best he could under the tense circumstances, he returned to Paris the following afternoon, pledging a longer visit to Morocco in days to come, a promise he kept. ${ }^{103}$

The most poignant and politically significant circumstance of the funeral ceremonies, upsetting all the calculations of Lemaigre Dubreuil's murderers and surprising all France and Morocco, was the overwhelming presence of Moroccans - nationalist militants and sympathizers, merchants and members of the urban middle class, and 'simple workers' from the medina. Estimated at 2500, this crowd easily filled the cathedral, spilling out its main doors into the square 
fronting the church and down the side streets. Official Morocco was there, too: the pasha of Casablanca, Si Bouchaïb ben Korchi, represented sultan Moulay Ben Arafa, who had already sent his condolences and those of the Makhzen to the Lemaigre Dubreuil family. But unofficial Morocco, the 'great majority' of the mourners, was more impressive, especially as its men in djellabas and women in veils filed slowly past the funeral catafalque decorated with a single Légion $\mathrm{d}$ 'honneur and three croix de guerre avec palmes. And of the many wreaths at the church's entryway the tribute from the Parti Démocratique de l'Indépendance (PDI) was exceptional since it saluted Lemaigre Dubreuil as he would have wished to be remembered: 'killed in the service of France and of Morocco' (mort au service de la France et du Maroc). ${ }^{104}$

As Jean Rigault, Lemaigre Dubreuil's long-time associate, put it squarely, Lemaigre Dubreuil's tragic death had given an 'exemplary value' to his life. Suddenly he had many more friends than when he was alive. And a flock of politicians was already descending on Morocco 'to try to exploit his dead body.' 105 To be sure, Premier Faure and Pierre July now spoke a new and stronger language against counter-terrorism and had begun to bring the Residency and the Moroccan lobby to heel. Lacoste was quickly replaced as resident general with a tough Gaullist administrator and reputed 'liberal,' High Commissioner of the Saar Gilbert Grandval, whose appointment was announced nine days after the assassination. And Marshal Juin, heretofore untouchable on his military Mount Olympus but embarrassed by the publication of a note of sympathy that he had sent to Simone Lemaigre Dubreuil that seemed to commend her husband's activities, was pressed to resign as a member of the North African Coordination Committee from where he had fingered all Maghreb policy. ${ }^{106}$

Relentlessly, L'Express, now in its third year of hard-hitting news stories, kept up the heat on the government. Director Jean-Jacques Servan-Schreiber, who had spent two days in Casablanca attending the funeral, researching his report on Lemaigre Dubreuil, and conferring with Mendès France, was in no mood for compromise. As he saw it:

The man who has just fallen had led a struggle since March without respite against the resignation, the paralysis, the impotence, and the complicity of French policy. Now it is up to French public opinion to ensure this change and impose what Lemaigre Dubreuil sought in vain until his dying day - that the French government accept its responsibilities in Morocco instead of abandoning that country to the fate of feudal chieftains and assassins. ${ }^{107}$

In the same issue of L'Express Pierre Mendès France and François Mauriac explored the political significance of the assassination. The former premier, who saluted Lemaigre Dubreuil as an 'important member of the wartime resistance' ( $u n$ grand résistant), a 'passionate patriot,' and a 'dedicated champion of African France' (un fervent de la France africaine), believed that his death demonstrated to Frenchmen in metropolitan France not only the existence but the importance of liberal French opinion in Morocco. And that these French liberals, who sought to 
promote a peaceful dialogue with Moroccans on the future of the country, firmly rejected the current policy of force, desiring instead a Franco-Moroccan agreement entered into freely. Thus, the lines of separation in Morocco were not necessarily between two peoples - as it was so often portrayed - but between those who trusted in force and those who embraced amicable exchange; as well as a debate among Frenchmen on how to deal with the inevitable political, economic, and social evolution of Morocco. The Frenchmen who believed in dialogue gave Mendès France a 'powerful reason to hope,' encouraged by the vivid spectacle of thousands of Moroccans at a funeral to show their respect for and gratitude to a Frenchman they did not know. That in itself, he said, constituted 'an event.' Moreover, he reasoned that the voice of those who had fought alongside Lemaigre Dubreuil, and who still wished to carry on, should now be 'better and more fully understood.' Ultimately, France's future conduct in Morocco was a matter for the Residency, the French government, and particularly the 350,000 Frenchmen of Morocco themselves, who first needed to renounce counterterrorism and then begin to share 'constructive suggestions' on Moroccan policy with their compatriots in the Metropole. This was the only way to revive the country and set it on course for its African future. 108

For Mauriac Lemaigre Dubreuil's sacrifice contributed (albeit in a tragic and ironic way) to the owner of Maroc-Presse's own desire that when the years of killing had finally ended, France and Morocco would not be 'spiritually separated.' With so many victims, explained Mauriac, some had to belong to both peoples. 'The Frenchmen of Morocco and the Moroccans themselves can take equal pride in the name of Jacques Lemaigre Dubreuil. In order to seal a friendship between two peoples, it means a great deal to have the same martyrs.' 109

Although Resident General Grandval cracked down on counter-terrorism by beginning to reorganize the protectorate's security services, he did not have an easy time of it in an environment of hostile Europeans and apprehensive and impatient Moroccans. In his first week on the job he lifted the detention laws for Moroccans convicted of illegal political or trade union activity. But a terrorist attack near a Casablanca café on the Rond-Point de Mers Sultan on 14 July that killed six Europeans and wounded more than thirty others compromised his plans. It triggered two days of serious street fighting between armed Europeans and Moroccans, forcing Grandval to proclaim a state of siege in the city and call on the Foreign Legion to restore order. Maroc-Presse, now under de Moustier's very competent lead, blamed Paris, insisting that Moroccans were at the end of their ropes and the government had to define its intentions and ultimate goals in Morocco (and how it would reach them) or lose the sympathy that Lemaigre Dubreuil's sacrifice had won. ${ }^{110}$ Worse was to come. On the second anniversary of Mohammed Ben Youssef's exile (20 August), the Berber countryside exploded in a series of uprisings that resulted in 'massacres' among the European population at Boujad and Oued-Zem, again requiring the army, backed up by tanks and planes, to come to the rescue. It was now clear to all but the most obtuse observers that Morocco's cities and countryside were united in support of the exiled sultan and in violent opposition to protectorate status quo. ${ }^{111}$ 
Grandval did push the Regency Council plan that Lemaigre Dubreuil had championed and a version acceptable to the sultan-in-exile was endorsed by a Franco-Moroccan conference at Aix-les-Bains at the end of August. But the resident did not approve of these top-level discussions, orchestrated and conducted by the premier and four members of his cabinet, for they undercut his own authority and he resigned after only 50 days on the job. ${ }^{112}$ The Regency Council was formally accepted by Mohammed Ben Youssef the following month, but it, too, was short-lived, since Istiqlal's objections blocked its use as a neutral ground to discuss the sultanate question. When Mohammed Ben Youssef's chief Moroccan adversaries (the pasha of Marrakech and the last hold-outs among the Berber tribal leaders) reversed course and rallied to his side, the political deadlock in France and Morocco broke. Acting on these dramatic new political realities, the government of Premier Faure (who confided that this had been his aim all along) restored Mohammed Ben Youssef to the sharifian throne in November 1955, less than five months after Lemaigre Dubreuil's death. Moroccan independence was confirmed in a protocol signed by French Foreign Minister Christian Pineau and Moroccan Premier M'Barek Ben Bekkaï in Paris on 2 March 1956. ${ }^{113}$

How important had Lemaigre Dubreuil been in all this? His political sparring partner, Pierre Boyer de Latour, who moved from Tunis to Rabat to replace Grandval as resident general for a two-month stint, called Lemaigre Dubreuil's assassination 'a decisive turning point in Moroccan history' and it is difficult to disagree. ${ }^{114}$ On the eve of his triumphal return to Morocco Mohammed Ben Youssef, already hailed for some time as Mohammed V (and soon to have this title officially with the proclamation of the monarchy in August 1957), acknowledged that Lemaigre Dubreuil's death was a cruel blow for every Frenchman and Moroccan who had wanted to see confidence and friendship triumph over skepticism and hatred. He told Baudouin de Moustier (on 5 November) that he had wanted to be present in Casablanca to share in the grief at the time of the funeral. But when he later learned that the Moroccan people had come to the cathedral in such large numbers, he knew that he could not have had any better representatives. ${ }^{15}$ This generous albeit astute statement was in spite of the fact that Lemaigre Dubreuil had supported his restoration only indirectly! And in the wave of street name changes that came after independence, replacing the names of French heroes with those of Moroccan martyrs, the Place de la Révolution Française in Casablanca was re-baptized Place Jacques Lemaigre Dubreuil. ${ }^{116}$ 


\section{Conclusion}

Lemaigre Dubreuil's assassination ended a turbulent career on a note of hope, for although this was not the fate he had marked out for himself, his death accomplished some of what he had wanted to achieve between France and Morocco. And he was a willing risk-taker whenever the interests of France were at stake. As soldier, as president of Georges Lesieur et ses Fils and of the Taxpayers' Federation, as an elected member of the Bank of France, as a wartime conspirator with America and counselor to General Giraud, as a postwar writer of books and articles, as a newspaper owner, and as an adviser to his countrymen (and one president and three premiers of the Fourth Republic) on matters Moroccan, he displayed the daring, patriotism, imagination, and conviction that characterized everything he did. In truth, if he was a conservative by instinct and upbringing, he was a rebel of sorts at heart. Only at the very end of his life, however, did he find the success or recognition in the civic sphere that matched his accomplishment in the economic marketplace.

The Taxpayers' Federation was mocked by its contemporary critics as a front for the interests of big business, another one among the handful of pre-war 'fascist leagues.' The reality is more complicated, beginning with the important fact that Lemaigre Dubreuil became federation president over a year after the violent Paris street marches of 6 February 1934 that so worried democratic observers in France. He steered it toward less adventurous activities than tax strikes and assaults on the Republic, yet for good reason the federation would always remain a thorn in the side of French local and national leaders until it was suspended in 1939 at the outbreak of war. Without question the federation expressed a real middle-class concern over high taxes and government spending which it translated into a public rhetoric with a militant edge. Its opponents preferred to dismiss the challenge, tarring its leaders with the anti-republican brush, and from the mid-1930s onward Lemaigre Dubreuil was identified somewhat disparagingly as the head of the 'ligue des contribuables,' putting him among the divisive elements of France's contentious past.

The French participation in the Allied landings in North Africa in November 1942 is one of the least understood 'events' of the Second World War. The invasion failed to make General Henri Giraud the French hero the Americans had slated him to become; and the Americans and the French North African command spurned 
de Gaulle. Ultimately Eisenhower enthroned Darlan, considered at the time an arch-collaborator with Germany, and, even after the admiral was dispatched, Giraud could not manage the part. De Gaulle finally took the role and quickly made Algiers the political jumping-off point for the liberation of France. This was Lemaigre Dubreuil's goal as well, but wartime politics and personal rivalries frustrated the unity that all Frenchmen said they sought. Despite his effort in French Africa, Lemaigre Dubreuil remained largely unknown to the Resistance (and unheralded by its historians) inside and outside France.

Morocco transformed all else. With his newspaper articles and through his contacts in France and Morocco Lemaigre Dubreuil became a leader among French 'liberals' seeking a peaceful resolution to Franco-Moroccan strife. His straight talk, common-sense arguments, and earnest pleas gained him a reputation as someone to be listened to in an increasingly polarized atmosphere. From the first he rejected the policy of force and 'cruel indifference' that he believed would bring to naught 'an endeavor born of confidence, consolidated in mutual esteem and hallowed by the blood shed on countless battlefields.' And although he opposed both terrorist and counter-terrorist violence, he explained the former as desperate acts of Moroccan patriotism and the latter as organized killings by French extremists. Even before his assassination in Casablanca Lemaigre Dubreuil had reinvented himself, in the end becoming a martyr to Franco-Moroccan solidarity. 



\section{Notes}

\section{Preface}

1 On Mauchamp, see Jonathan G. Katz, 'The 1907 Mauchamp Affair and the French Civilizing Mission in Morocco,' The Journal of North African Studies, 6, no. 1 (Spring 2001), pp. 143-66.

2 Albert Kammerer, Du Débarquement africain au meurtre de Darlan (Paris, 1949), p. 58.

3 The film was a remake of Hitchcock's 1934 British film of the same name.

\section{Taxpayer revolt in France}

1 La C.G.C. (the monthly publication of Kula's Confédération Générale des Contribuables), 5 July 1930; Auguste Cavalier, La Révolte des contribuables (Paris, 1932), pp. 25, 57. Kula was a well-known supplier of plumbing and roofing materials (Kula Frères) and his company name still remains emblazoned on the water taps in Paris apartments of a certain age.

2 On Coty, see Alfred Kupferman, 'François Coty, journaliste et homme politique' (Doctorat de Troisième Cycle, Faculté des Lettres et des Sciences Humaines de Paris, 1965); Kenneth Mouré, The Gold Standard Illusion: France, the Bank of France and the International Gold Standard, 1914-1939 (Oxford, 2002).

3 On these problems, see the contemporary American assessments by Eleanor Lansing Dulles, The French Franc, 1914-1928 (New York, 1929); Robert M. Haig, The Public Finances of Post-War France (New York, 1929); and James Harvey Rogers, The Process of Inflation in France, 1914-1927 (New York, 1929). Also see Tom Kemp, The French Economy, 1913-1939, The History of a Decline (New York, 1972); Kenneth Mouré, Managing the Franc Poincaré: Economic Understanding and Political Constraint in French Monetary Policy, 1928-1936 (New York, 1991); Alfred Sauvy, Histoire économique de la France entre les deux guerres, 3 vols. (Paris, 1965-72); Stephen A. Schuker, The End of French Predominance in Europe: The Financial Crisis of 1924 and the Adoption of the Dawes Plan (Chapel Hill, 1976); and Martin Wolfe, The French Franc Between the Wars, 1919-1939 (New York, 1951).

4 Le Temps, 11 February 1907, quoted in Haig, The Public Finances of Post-War France, p. 13.

5 See Theodore Zeldin, France, 1848-1945, 2 vols. (Oxford, 1973-77), 1, p. 712.

6 Haig, The Public Finances of Post-War France, p. 402; Carl S. Shoup, The Sales Tax in France (New York, 1930), pp. 3, 22-3, 353.

7 Archives de la Préfecture de Police (Paris), B/A 351p 79501-953-1 (Fédération Nationale des Contribuables), Folder E, report of 31 March 1931 (hereafter cited as APP).

8 APP, Folder D, report of 1 December 1929; Le Réveil du contribuable, March 1930 and June 1930. 


\section{The assassination of Jacques Lemaigre Dubreuil}

9 Ibid., Folder F, report of 8 December 1928.

10 APP, Folder E, report of 23 September 1932.

11 APP, Folder D, report of 12 December 1931.

12 APP, Folder D, report of 23 November 1930.

13 APP, Folder D, reports of 23 November 1930 and 12 December 1931; Folder F, report of 23 September 1932; Folder E, report of 8 November 1933. Alfred Kupferman believes that Coty stopped funding the federation in 1930. See Kupferman, 'François Coty, journaliste et homme politique,' pp. 199-200.

14 APP, Folder D, report of 12 December 1931. In the report of the parliamentary committee to investigate the riots of 6 February 1934, the director of police information services put the federation's membership at 700,000, a figure which probably came from the federation's own records. See Marc Rucart, Rapport général fait au nom de la commission d'enquête chargée de rechercher les causes et les origines des événements du 6 février 1934 et jours suivants, ainsi que toutes les responsabilités encourues, 4 vols. (Paris, 1934), 4, pp. 6, 135 (hereafter cited as Commission du 6 février).

15 APP, Folder D, reports of 12 December 1931 and 27 January 1932.

16 APP, Folder E, report of 26 October 1931.

17 APP, Folder E, report of 23 September 1932. Also see Le Réveil du contribuable, March and December 1930.

18 APP, Folder D, report of 1 December 1929.

19 APP, Folder F, report of 17 February 1931.

20 APP, Folder E, report of 30 October 1932; Henry Dorgères, Haut les fourches (Paris, 1935). At first Dorgères's organization was called the Comités de Défense contre les Assurances Sociales, then simply the Comités de Défense Paysanne.

21 APP, Folder F, report of 2 September 1930.

22 Henri Dorgères, Au XXe siècle 10 ans de jacquerie (Paris, 1959), pp. 54-6, 59.

23 Sauvy, Histoire économique de la France, 2, pp. 490-1; Dorgères, Haut les fourches, pp. 31-60. Also see Sauvy, 'The Economic Crisis of the 1930s in France,' Journal of Contemporary History, 4, no. 4 (October 1969), pp. 21-35. On the inter-war farmer movements, see Suzanne Berger, Peasants Against Politics: Rural Organization in Brittany, 1911-1967 (Cambridge, 1972); Robert O. Paxton, French Peasant Fascism: Henry Dorgères's Greenshirts and the Crises of French Agriculture, 1929-1939 (New York, 1997); Jean-Michel Royer, 'De Dorgères à Poujade,' in Jacques Fauvet and Henri Mendras, eds, Les Paysans et la politique dans la France contemporaine (Paris, 1958), pp. 149-206; and Gordon Wright, Rural Revolution in France: The Peasantry in the Twentieth Century (Stanford, 1964).

24 APP, Folder D, reports of 1 December 1929 and 23 November 1930; La C.G.C., 5 January and 5 August 1928.

25 Ibid. La C.G.C., 5 January and 5 August 1928.

26 APP, Folder D, report of 27 January 1932.

27 APP, Folder D, report of 12 December 1931.

28 Ibid.

29 Ibid. and Le Réveil du contribuable, December 1930.

30 APP, Folder D, report of 27 January 1932. Among the more interesting groups supporting the federation were the Association des Petits Fabricants Français; the Chambre Syndicale des Garagistes; the Chambre Syndicale des Marchands de Bestiaux; the Confédération Nationale des Expéditeurs et Producteurs de Denrées Périssables; the Fédération Nationale des Transporteurs; the Fédération Nationale des Syndicats des Expéditeurs de Volailles, Beurres, et Oeufs; the Fédération des Expéditeurs de Fruits et Légumes Primeurs; the Syndicats de la Boucherie de Paris et du Département de la Seine; the Syndicat des Imprimeurs Typographes; the Syndicat de Défense de la Petite Propriété Immobilière et Mobilière; the Syndicat Général des Motoristes et Vélocistes, Agents d'Automobiles et de Cycles; and the Union Artisanale Française. 
31 Le Réveil du contribuable, April 1932. Also see APP, Folder F, reports of 29 May 1931 and 6 February 1932.

32 APP, Folder F, report of 15 March 1932.

33 APP, Folder F, report of 2 June 1932.

34 Ibid.

35 Le Réveil du contribuable, July 1932.

36 APP, Folder F, report of 28 June 1932.

37 Le Réveil du contribuable, July 1932.

38 APP, Folder E, report of 26 June 1932.

39 Le Réveil du contribuable, November 1932.

40 APP, Folder E, report of 29 January 1933.

41 APP, Folder B, reports of 10 and 25 March 1933.

42 Ibid.

43 APP, Folder B, report of 25 March 1933.

44 APP, Folder F, report of 28 April 1933.

45 Le Peuple, 22 March 1933.

46 Le Populaire, 20 March 1933.

47 L'Humanité, 21 March 1933. The Communists made it clear that their position on taxpayer unrest was quite different from that of the Socialists. 'Are we - as are the Socialist leaders and Léon Blum - against the demonstrations of taxpayers, shopkeepers, and peasants? No ... ! We must explain to the Socialist workers that the attitude of their leaders is dictated here, as elsewhere, by the desire not to cause any trouble for the Radical government, [but] to support it, to serve it against all those who oppose the new tax measures.'

48 Le Temps, 21 March 1933.

49 Journal Officiel de la République Française, Débats parlementaires, 11 February 1933, pp. 590-1 and Gaston Jèze, 'Le refus concerté de payer l'impôt,' Revue de science et de législation financières, 31 (1933), pp. 257-60.

50 Débats parlementaires, 11 February 1933, pp. 590-1.

51 Le Réveil du contribuable, March 1933.

52 Le Contribuable de Saône-et-Loire, June 1933.

53 APP, Folder E, report of 19 May 1933.

54 APP, Folder F, report of 1 May 1933.

55 APP, Folder E, reports of 19 and 25 May 1933.

56 APP, Folder E, report of 27 May 1933.

57 Ibid.

58 APP, Folder E, report of 19 May 1933; Folder F, reports of 26 and 30 May 1933.

59 L'Ami du peuple, 29 May 1933. Large was sentenced to 15 days in jail and given a 100 franc fine. APP, Folder F, report of 12 July 1933.

60 Le Journal, 31 May 1933 and L'Ami du peuple, 30 May 1933.

61 L'Ami du peuple, 2 June 1933.

62 Ibid.

63 APP, Folder F, report of 6 December 1933.

64 APP, Folder D, report of 18 July 1933.

65 APP, Folder E, report of 8 November 1933; Folder D, report of 10 November 1933; Folder C, report of 23 October 1933.

66 APP, Folder D, report of 10 November 1933.

67 APP, Folder D, reports of 15 and 17 December 1933.

68 APP, Folder F, report of 27 December 1933.

69 APP, Folder F, report of 10 January 1934.

70 Le Réveil du contribuable, July-August-September 1934. Large turned down an offer from François Coty to organize taxpayer rallies in support of a mammoth Paris meeting of Solidarité Française; Coty had offered to pay the federation 25,000 francs per rally. See APP, Folder F, report of 7 November 1933. Large also refused to march 


\section{The assassination of Jacques Lemaigre Dubreuil}

with the Cartel Confédéré des Services Publics or to discuss the tax grievances of liquor retailers. See APP, Folder F, reports of 23 November and 1 and 6 December 1933.

71 L'Assujetti, January 1934.

72 L'Action française, 7 January 1934, quoted in Eugen Weber, Action Française: Royalism and Reaction in Twentieth-Century France (Stanford, 1967), pp. 321-2.

73 Charles Serre, Rapport fait au nom de la commission chargée d'enquêter sur les événements survenus en France de 1933 à 1945, 9 vols. (Paris, 1952), 1, p. 14.

74 APP, Folder F, reports of 23, 26, and 27 January 1934. Also see Commission du 6 février, 4, pp. 4, 11, 61 .

75 Commission du 6 février, 4, p. 121. A guide to the source material and some of the secondary literature on 6 February is Serge Berstein's excellent Le 6 février 1934 (Paris, 1975). Also see Philip C. F. Bankwitz, 'Paris on the sixth of February, 1934: Riot, insurrection, or revolution?' in Brison D. Gooch, ed., Interpreting European History (Homewood, 1967), pp. 337-68; Max Beloff, 'The Sixth of February,' in James Joll, ed., The Decline of the Third Republic, St. Antony's Papers, No. 5 (London, 1959), pp. 9-35; René Rémond, 'Explications du 6 février,' Politique, nos. 7-8 (July-December 1959), pp. 218-30; and Geoffrey Warner, 'The Stavisky Affair and the Riots of February 6th 1934,' History Today, June 1958, pp. 377-85. Richard F. Kuisel, Ernest Mercier, French Technocrat (Berkeley, 1967) on the veterans' groups and Weber, Action Française on the Camelots du Roi are also important.

76 Commission du 6 février, 4, p. 120.

77 L'Action française, 8 February 1934.

78 Commission du 6 février, 4, pp. 46-53; 2, pp. 1661-79.

79 Bulletin des contribuables de l'Aisne, May 1934.

80 Le Réveil du contribuable, July-August-September 1934.

81 Ibid.

82 Le Réveil du contribuable, October and November 1934.

83 Javal was president of Ordre et Bon Sens, an organization founded in 1930 by Paris journalist Louis Forest (Louis Nathan) to funnel money to groups that opposed Socialist politics and Left-wing labor organizations. Ordre et Bon Sens supported both the Taxpayers' Federation and Peasant Defense with cash contributions and publicity in Forest's weekly L'Animateur des temps nouveaux (later, $L$ 'Espoir français). Forest also wrote for the Paris daily Le Matin ('Propos d'un Parisien') and it was he who arranged for Dorgères to write a column for Le Matin every other week which gave the peasant leader important exposure in the French capital.

84 L'Action contribuable, January 1935. L'Action contribuable replaced Le Réveil du contribuable as the Taxpayers' Federation's monthly newspaper.

85 Arthur Young, Travels in France (London, 1889), p. 21. The Lemaigre Dubreuil family traced its roots to a seventeenth-century ancestor, Le Maigre du Breuil, one of four brothers who shared 'Le Breuil,' a rural property near Solignac.

86 See the speech by Lemaigre Dubreuil at a meeting of the board of directors of the Taxpayers' Federation in La C.G.C., July 1935.

87 'Curriculum vitae et citations du capitaine Jacques Lemaigre Dubreuil,' n.d. (Lemaigre Dubreuil Papers, Paris). In the citation for the Legion of Honor, General Paul de Lavigne Delville noted that Lemaigre Dubreuil's boldness and initiative were 'legendary.'

88 For the company history, see Georges Lesieur et ses Fils, 'Historique,' n.d. (Lemaigre Dubreuil Papers). Although Lesieur had nothing to do with petroleum, Georges Lesieur did help to finance the Société Générale des Huiles de Pétrole in 1921. According to company archives, this was the only time that peanut oil and petroleum ever mixed.

89 La C.G.C., July 1935.

90 Ibid. The immediate cause of the 6 February 1934 march on the Palais Bourbon was the firing of Paris police chief Jean Chiappe who had a tough, no-nonsense reputation 
in a scandal-ridden city. His dismissal was taken to signal the end of any serious pursuit of the guilty parties in the Stavisky scandal, a municipal bond swindle that had implicated government officials.

91 Ibid.

92 Le Journal, 3 March 1935 and Ibid.

93 Le Journal des débats, 5 April 1935. Also see Le Matin, L'Ordre, L'Ami du peuple, and Le Jour on 4 April 1935; and Le Temps, 5 April 1935.

94 'Discours de Monsieur Jacques Lemaigre Dubreuil au déjeuner du 4 avril 1935,' (René Lemaigre du Breuil Papers).

95 L'Action contribuable was the federation mouthpiece, supplying information to the Paris and provincial press as well as to numerous regional and local taxpayer publications, such as the Bulletin des contribuables de l'Aisne (Saint-Quentin), Le Cri du contribuable (Chalon-sur-Saône), La Tribune des contribuables de Franché-Comté (Besançon), and La Voix du contribuable (Lyon). For a short time, beginning in 1936, there was even a German-language edition of L'Action contribuable, Die SteuerPresse, published at Strasbourg.

96 The federation advertising agency handling all this was AGINCO (Agriculture, Industrie, Commerce), located on the Champs-Élysées. Aginco's biggest clients were Lesieur, Au Printemps, Usines Renault, Thibaud Gibbs et Cie., Distillerie de la Suze, and Olida. Lesieur and $\mathrm{Au}$ Printemps were family affairs; the sister of Simone Lemaigre Dubreuil (née Lesieur) was married to Pierre Laguionie, president of $\mathrm{Au}$ Printemps.

97 See the contemporary report in the pro-farmer L'Ami du peuple, 21 April 1935. Also see the even-handed but farmer-friendly account in Louis Gabriel-Robinet, Dorgères et le front paysan (Paris, 1937), pp. 29-30 and Dorgères's own recollections, Au XXe siècle 10 ans de jacquerie, pp. 79-80. Paxton's account of this incident emphasizes the threat that government officials imagined Dorgères posed to the Republic; see French Peasant Fascism, pp. 63, 135-6.

98 See Lemaigre Dubreuil's letter to Laval in Le Journal des débats, 18 July 1935 and Action française, 17 July 1935. Also see an earlier letter to Premier Pierre-Étienne Flandin in Le Jour, 26 April 1935 and Le Temps, 27 April 1935. For Dorgères's memories, see $\mathrm{Au}$ XXe siècle 10 ans de jacquerie, pp. 93-4. Bouton was cleared of all charges.

99 See Le Journal, 9 July 1935; Le Journal des débats, 10 July and 11 September 1935; Le Jour, 10 and 17 September 1935; and Action française, 17 September 1935.

100 Le Journal des débats, 21 September 1935.

101 Le Journal, 19 September 1935 and La Liberté, 20 September 1935.

102 Louis Goury de Roslan, treasurer of Peasant Defense and a successful businessman, stayed with the Taxpayers' Federation as secretary-general of Rural Alliance.

103 Fédération Nationale des Contribuables, Les Contribuables (Paris, 1935), p. 176.

104 Bulletin des contribuables de l'Aisne, August-October, 1935; Les Contribuables, pp. 22-3.

105 Les Contribuables, pp. 9-11.

106 Former Minister of Finance Henry Germain-Martin quotes similar statistics in Le Problème financier, 1930-1936 (Paris, 1936), p. 297.

107 Les Contribuables, pp. 12-14.

108 Les Contribuables, pp. 14-15.

109 Les Contribuables, pp. 19-20.

110 Les Contribuables, pp. 24-5.

111 Les Contribuables, pp. 32-41.

112 Les Contribuables, pp. 44-5, 47-9, 56-62. The taxpayers did not favor the 40-hour work week, the Left's solution for unemployment. They insisted that business and industry could not absorb all the currently unemployed workers simply as the result of a shorter work week since labor demand was a function of job training and skills, the specific sector of the economy, and geography. Moreover, the 40 -hour work week 


\section{The assassination of Jacques Lemaigre Dubreuil}

would increase wholesale prices by 20 percent and consumer prices as well, create an unfavorable balance between French and world prices and a similar gap between French industrial and agricultural prices. A shorter work week would also hasten mechanization and increase the female work force; both tended to aggravate rather than alleviate unemployment. Finally, since the 40-hour work week would not apply to the countryside, this reform would create yet another difference between farm and factory conditions, encouraging rural exodus and reducing farm purchasing power. Les Contribuables, pp. 49-55.

113 Les Contribuables, pp. 26-7, 62.

114 Les Contribuables, pp. 63, 66-9.

115 Les Contribuables, pp. 63-8. Integral universal suffrage meant the vote for all adult men and women and for the head of the household as a function of the number of children that he/she represented. Therefore, one voter could have more than one vote. See Les Contribuables, p. 90.

116 La Tribune des contribuables de Franche-Comté, June 1936.

117 Le Jour, 15 March 1937.

118 L'Ami du peuple, 24 June 1937; Action française, 25 June 1937; and Le Matin, 11 January 1938.

119 Les Contribuables, pp. 45-6.

120 Ibid. and Dorgères, Haut les fourches, p. 80.

121 Les Contribuables, p. 25.

122 Les Contribuables, pp. 76-81.

123 Les Contribuables, pp. 81-9. Also see Hervé Detton, L'Administration régionale et locale en France (Paris, 1960) and Robert Kent Gooch, Regionalism in France (New York, 1931).

124 Les Contribuables, pp. 93-100.

125 Les Contribuables, p. 95.

126 Les Contribuables, pp. 104-5.

127 Les Contribuables, pp. 101-7.

128 Robert O. Paxton, Vichy France: Old Guard and New Order, 1940-1944 (New York, 1972), pp. 243-9. Also see Julian Jackson, The Politics of Depression in France, 1932-1936 (New York, 1985).

129 See Action française, 17 May and 7 June 1935; Bulletin des contribuables de l'Aisne, July 1935, February 1936; Le Canard enchainé, 10 April 1935; Le Jour, 6 and 7 June 1935; Le Journal des débats, 16, 18, 24, and 26 May 1935; La Liberté, 8 and 9 June and 6 February 1935; Le Matin, 18 January and 4 February 1936; Le Temps, 8 June 1935; La Tribune des contribuables de Franche-Comté, November 1936; and Les Contribuables, p. 143.

130 Les Contribuables, p. 165.

131 Le Matin, 25 January 1936.

132 'Contre les politiciens, Votez pour une représentation professionnelle,' Lemaigre Dubreuil Papers.

133 See La Liberté, 6 February 1936.

134 Lemaigre Dubreuil, 'Les Français sont tous solidaires,' La Tribune des contribuables de Franche-Comté, May 1936.

135 Sauvy, Histoire économique de la France, 2, pp. 187-8. For Blum's views on a balanced budget and deficit spending, see Joel Colton, Léon Blum: Humanist in Politics (New York, 1966), pp. 178-9.

136 Sauvy, Histoire économique de la France, 2, pp. 183-5.

137 Action française, 18 June 1936; Le Cri du contribuable, August 1936; La Liberté, 19, 26, 27, and 28 June 1936; Le Matin, 18 June 1936; and La Tribune des contribuables de Franche-Comté, June and July 1936.

138 Lemaigre Dubreuil, 'L'Expérience actuelle,' La Tribune comtoise (formerly La Tribune des contribuables de Franche-Comté), August-September 1936.

139 Clara K. Sullivan, The Tax on Value Added (New York and London, 1965), pp. 64-70; 
Henry Laufenburger, 'Technical and Political Aspects of Reform of Taxation in France,' National Tax Journal, 6 (1953), p. 277. For the Popular Front's tax legislation, see Sauvy, Histoire économique de la France, 2, p. 247.

140 Founded in 1800 by Napoleon Bonaparte, the Bank of France, located at the apex of the centralized French banking system, has been called 'the outstanding financial institution of France.' The exclusive bank of issue, the bank of discount for other French banks, the banker to the government, and the clearing house for the country's banking transactions, the Bank of France, while legally a private corporation whose shares traded on the Paris Bourse, was considered by Frenchmen to be a national institution. In 1929 economic historian James Harvey Rogers wrote of the Bank: 'The position of the Bank of France is unique. Probably no banking institution in the world, with the possible exception of the Bank of England, has ever commanded more general respect and esteem. A Frenchman may lose faith in his Government ... but never in his Bank.' (Rogers, The Process of Inflation in France, p. 339.)

For the six years from 1800 to 1806 the management of the Bank remained in the hands of the stockholders, or more correctly the 200 largest stockholders, who chose the Council of Regents. In 1806 the Council's independence was reduced by the appointment of a governor and two deputy governors by the head of state, indicative of the control which the state deemed necessary over an institution which rendered 'peculiar and indispensable services' to the nation's banks as well as to the state. From that time the Bank took on a semipublic character. And in the 1920s because of the enormous funds advanced to the state, the Bank was even likened to a branch of the finance ministry. In fact, advances to the state were said to have 'almost completely dominated the affairs of the Bank itself, and consequently very largely determined the credit conditions prevailing throughout the country.' (Rogers, The Process of Inflation in France, pp. 18-19, 22, 340.)

Despite the presence of state appointees at the Bank, not every government could count on good relations with France's premier financial institution. The regents still exerted considerable influence, representing as they did the wealthiest and most powerful business, industrial, and banking interests in France. And they were decidedly hostile to the parties of the Left. In 1925 Leftists accused the Bank of sabotaging the Herriot government by revealing that Herriot had asked the governor of the Bank to understate the quantity of notes in circulation. Although Herriot's conduct in this matter was considered scandalous, the Bank had long permitted conservative governments to conceal the amount of currency in circulation, albeit in more discrete ways (Martin Wolfe, The French Franc Between the Wars, pp. 35-6). And in 1936 the Left charged that the Bank was secretly financing the campaigns of anti-Popular Front candidates (Wolfe, The French Franc Between the Wars, p. 141, citing Walter R. Sharp, The Government of the French Republic [New York, 1938], pp. 246-7). Predictably the Popular Front pledged to make the Bank of France the Bank of Frenchmen.

141 See Colton, Léon Blum, pp. 185-6.

142 Colton notes that the Popular Front derived little financial benefit from the revalorization of the Treasury's gold holdings. See Léon Blum, p. 189.

143 Lemaigre Dubreuil, 'L'Epérience actuelle,' La Tribune comtoise, August-September 1936. Also see Lemaigre Dubreuil, 'Vers la chute? Non, vers le salut!', La Tribune comtoise, October 1936.

144 Le Jour, 7 October 1936. Also see La C.G.C., 1937 and Die Steuer-Presse, October 1936.

145 Le Jour, 23 October 1936; Le Journal des débats, 5 November 1936; Le Matin, 20 and 29 October and 14 November 1936. Lemaigre Dubreuil's case was thrown out of court on the grounds that devaluation was not a personal act but an act of government. Furthermore, that decision had been ratified by the Chamber of Deputies. Never theless, the government did agree to grant special concessions to Auriol bond holders in the 1937 bond issue. See Le Matin, 18 December 1936. 


\section{The assassination of Jacques Lemaigre Dubreuil}

146 Although the law of 25 July 1936 on the Bank of France made major administrative changes, the Bank was not nationalized outright, as some reformers wanted, by expropriating the stockholders' shares and repaying them with government bonds (see Wolfe, The French Franc Between the Wars, p. 141, citing A. Dumora, La Réforme de la Banque de France et l'évolution monétaire de juin 1936 à juin 1937 [Bordeaux, 1939]). Even so, the power of the Council of Regents was broken. The stockholders' assembly, enlarged from the original 200 members to over 40,000 , was permitted to elect only five representatives (two councillors, three advisers) to the Bank's new 23member General Council. The rest of the members were government appointees or subject to government approval (see Wolfe, The French Franc Between the Wars, pp. 141-2 and Colton, Léon Blum, pp. 182-4; George Boris, 'Reforming the Bank of France,' Foreign Affairs, 15 [1936], pp. 155-64; Karl R. Bopp, 'The Government and the Bank of France,' Public Policy, 2 [1941], pp. 3-35). The Popular Front majority in the Chamber of Deputies had tried to prevent the stockholders from electing any of the councillors, but the Senate amended the bill (see Le Temps, 17, 18, and 27 July 1936). Two-thirds of the more than 40,000 shareholders held only one or two shares of the Bank's stock (see Wolfe, The French Franc Between the Wars, p. 142, citing Margaret Myers, Paris as a Financial Centre [New York, 1936], p. 42).

147 La Libre Opinion, 11 October 1936; Le Matin, 16 October 1936; Le Journal des débats, 17 October 1936; La Liberté 17 October 1936; Le Jour, 17 October 1936; and Le Temps, 17 October 1936. Édouard Duhem, president of the Confédération des Syndicats Industriels et Commerciaux and vice-president of the Confédération Générale du Patronat Français, took the second seat. Duhem was a well-known critic of government policy as were the three Bank advisers elected by the shareholders: Gaston Bassot, Georges Baugnies, and Louis Compaignon de Marchéville.

148 Le Journal, 16 October 1936 and La Liberté, 17 October 1936.

149 Le Journal, 16 October 1936.

150 Lemaigre Dubreuil, 'La Banque de France asservie par l'État,' L'Action contribuable, 5 February 1937.

151 Lemaigre Dubreuil, 'Le plafond est-il crevé?' Le Journal, 16 January 1937.

152 L'Action contribuable, September 1938.

153 Lemaigre Dubreuil, 'Le plafond est-il crevé?' Le Journal, 16 January 1937. Lemaigre Dubreuil's charges were dismissed by the government as 'inaccurate' and 'completely without foundation.' See Le Journal, 17 January 1937.

154 L'Action contribuable, September 1938.

155 L'Écho de Paris, 10 February 1937 and Lemaigre Dubreuil, 'Il faut faire de la Banque de France la Banque de la nation,' L'Action contribuable, 19 February 1937.

156 Lemaigre Dubreuil, 'Il faut faire de la Banque de France la Banque de la nation,' L'Action contribuable, 19 February 1937 . Also see L'Action contribuable, 15 October 1937 and 15 January 1938.

157 L'Oeuvre, 1 February 1937.

158 La Liberté, 21 January 1937. Also see Lemaigre Dubreuil, 'Coup d'oeil sur le fonctionnement de la Banque de France devenue depuis dix-huit mois la "Banque de la France",' Le Journal, 24 January 1938.

159 Le Journal, 9 March 1937.

160 L'Action contribuable, 15 January 1938. Also see Lemaigre Dubreuil, 'La Banque de France asservie par l'État,' L'Action contribuable, 5 February 1937.

161 L'Action contribuable, March 1939.

162 Le Jour, 29 January 1937 and Le Canard enchainé, 3 February 1937.

163 Le Jour, 29 January 1937.

164 Le Jour, 4 December 1936 (Lemaigre Dubreuil's emphasis). Also see Le Journal, 8 and 12 December 1936.

165 Le Jour, 4 December 1936.

166 L'Action contribuable, 1 May 1938. 
167 Lemaigre Dubreuil, 'Un aspect inattendu du problème de l'or de la Banque d'Espagne,' Le Journal, 24 June 1938 and L'Action contribuable, 1 May, 1 July, and 1 August 1938.

168 Sauvy, Histoire économique de la France, 2, pp. 254-6 and Colton, Léon Blum, pp. 192-3.

169 Le Journal, 9 March 1937.

170 Ibid.

171 See Peter J. Larmour, The French Radical Party in the 1930's (Stanford, 1964), pp. 33, 210, 229, 234.

172 L'Action contribuable, 1 August 1937.

173 Le Jour, 29 January 1938.

174 Lemaigre Dubreuil, 'Étatisme, étatisme encore, étatisme toujours!' Vendémiaire, 15 September 1937; Lemaigre Dubreuil, 'En pleine équivoque,'Vendémiaire, 6 October 1937; and L'Action contribuable, 5 November 1937. For a general description and critical appraisal of the 40-hour week, see Colton, Léon Blum, pp. 167-76.

175 Lemaigre Dubreuil, 'Équilibre réel ou équilibre comptable,' Vendémiaire, 17 November 1937.

176 Lemaigre Dubreuil, 'Tout est-il pour le mieux dans le meilleur des budgets?' L'Action contribuable, 19 November 1937.

177 L'Époque, 25 November 1937 (Lemaigre Dubreuil's emphasis). Not surprisingly, Colton judged the Bonnet budget 'a retreat to the retrenchment program of Flandin and Laval, and a repudiation of Blum's purchasing power policy.' See Colton, Léon Blum, p. 287. On Bonnet as minister of finance, see Georges Bonnet, Défense de la paix, 2 vols. (Geneva, 1946-48), 1, pp. 29-45, 51-63.

178 L'Action contribuable, December 1938. Also see Le Jour, 29 January 1939; Le JourÉcho de Paris, 28 January 1939; and Sauvy, 'The Economic Crisis of the 1930's in France,' pp. 21-35. Reynaud's agreement also provided for an increase of interest-free loans to the Treasury which Lemaigre Dubreuil and the Taxpayers' Federation opposed.

179 L'Action contribuable, 26 July 1939.

180 L'Action contribuable, January 1939.

181 L'Action contribuable, February 1939.

182 Le Matin, 11 May 1937 and La Liberté, 12 May 1937.

183 François Latour, 'La grande misère du budget de Paris,' Le Journal, 16 July 1937. Also see Louis Beraud, 'Pour rétablir l'équilibre du budget de la ville,' Le Journal, 18 July 1937.

184 L'Action contribuable, 1 August 1937.

185 L'Action contribuable, 3 December 1937.

186 L'Action contribuable, 17 December 1937.

187 L'Action contribuable, 3 December 1937.

188 Le Journal des débats, 25 December 1937.

189 Conseil Municipal de Paris, Procès-verbaux et déliberations des séances de l'Assemblée du Conseil Municipal de Paris, année 1937 (27 December 1937), pp. 838-9 (hereafter Conseil Municipal de Paris). Also see Lemaigre Dubreuil, 'Le Problème financier de la ville de Paris,' Le Journal, 27 December 1937. The minutes of the Paris City Council are available at the Bibliothèque administrative de l'Hôtel de Ville.

190 L'Action contribuable, 1 February 1938; L'Époque, 10 February 1938; and Le Matin, 10 February 1938. A federation poster printed the names of 41 city councillors who had voted for the Paris budget. Forty were National Republicans (an alliance of Liberal Republicans, Independent Republicans, Left Republicans, and members of the Alliance Démocratique and the Fédération Républicaine). André Puech defended his vote for the budget in a short brochure, Propos de bonne foi à l'adresse du contribuable (Paris, 1938). 


\section{The assassination of Jacques Lemaigre Dubreuil}

191 L'Époque, 5 January 1938.

192 Ibid.

193 Gringoire, 28 January 1938.

194 L'Action contribuable, 15 May 1938 (Lemaigre Dubreuil's emphasis). Also see Lemaigre Dubreuil, 'La grande pitié des contribuables parisiens,' Le Journal, 9 May 1938.

195 L'Action contribuable, 15 June 1938.

196 L'Action contribuable, 1 July 1938.

197 Fédération Nationale des Contribuables, La Gestion de la ville de Paris: le projet $d u$ budget contribuable (Paris, 1938).

198 L'Action contribuable, December 1938; Lemaigre Dubreuil, 'Il serait possible d'économiser 1 milliard $1 / 2$ sur le budget parisien de 1939,' L'Ordre, 28 November 1938; Lemaigre Dubreuil, 'Près d'un milliard de dépenses pourrait être économisé du jour au lendemain,' L'Ordre, 29 November 1938; and Lemaigre Dubreuil, 'Les économies qui s'imposent réduiraient à zéro le déficit du budget de Paris,' $L$ 'Ordre, 2 December 1938. The articles in L'Ordre summarize the findings of La Gestion de la ville de Paris.

199 Le Journal, 9 and 16 December 1938; Le Journal des débats, 29, 30, and 31 December 1938; Le Matin, 25 and 30 December 1938. The Inter-professional Committee was composed of the following organizations: the Comite de l'Alimentation Parisienne, the Syndicat des Médecins de la Seine, the Comité Intersyndicale du Commerce des Combustibles, the Alliance Syndicale du Commerce et de l'Industrie, the Fédération Métallurgique Française, the Syndicat Général du Commerce et de l'Industrie, the Fédération Nationale des Négociants en Matériaux de Construction, the Fédération Nationale des Contribuables, the Fédération des Commerçants-Détaillants de France, the Fédération des Industries et Commerces d'Art et de Qualité, the Chambre Nationale du Commerce de l'Automobile, the Comité de Salut Économique, the Office du Bâtiment et des Travaux Publics, the Chambre Syndicale des Propriétaires, the Comité Central des Chambres Syndicales, and the Chambre Syndicale du Commerce en Gros des Vins et Spiriteux.

200 Conseil Municipal de Paris, année 1938 (9 and 20 December 1938), pp. 329-31, 605. Also see André Puech, 'Pour assurer l'équilibre du budget de Paris,' Le Journal, 10 December 1938.

201 Conseil Municipal de Paris, année 1938 (20 December 1938), p. 604.

202 Lemaigre Dubreuil, 'M. Paul Reynaud peut imposer à la ville de Paris quatorze cents millions d'économies,' L'Ordre, 21 and 30 December 1938.

203 Conseil Municipal de Paris, année 1938 (30 December 1938), p. 1056.

204 Conseil Municipal de Paris, année 1938 (30 December 1938), p. 1153.

205 Conseil Municipal de Paris, année 1938 (30 December 1938), pp. 1068-70.

206 Conseil Municipal de Paris, année 1938 (30 December 1938), pp. 1129-31, 1141-3.

207 Conseil Municipal de Paris, année 1938 (31 December 1938), pp. 1412, 1420.

208 Le Matin, 2 January 1939. Also see another notice, 'Les étrennes des contribuables parisiens,' in Le Journal des débats, 5 January 1939.

209 Le Journal des débats, 31 January 1939.

210 L'Action contribuable, January 1939. In March 1939 the prefect of the Seine announced a pay increase for municipal employees. This made the city salary scale higher than that for national government employees and broke a law. The Taxpayers' Federation publicized this violation, making clear that Minister of Finances Paul Reynaud had approved the prefect's decision. Lemaigre Dubreuil was indicted for 'atteint au crédit de l'état' and fined 2000 francs by the criminal court of the department of the Seine; the Court of Appeals later reversed this verdict. See L'Action contribuable, April, May, and June 1939 and 26 July 1939; Le Journal, 4 June 1939; Le Journal des débats, 11 March 1939; and Le Matin, 7 and 14 June 1939, 13 and 27 July 1939, and 7 August 1941. 
211 L'Action contribuable, 1 and 15 June 1938.

212 Lemaigre Dubreuil, 'Les leçons de Saint-Étienne,' L'Action contribuable, 1 June 1938.

213 L'Action contribuable, 1 and 15 June 1938.

214 L'Action contribuable, 1 July 1938.

215 Ibid.

216 L'Action contribuable, 1 August 1938. The Toulouse taxpayer coalition included the Association des Contribuables de Toulouse et de la Haute-Garonne, the Bloc Régional du Petit Commerce, the Chambre de Commerce de Toulouse, the Chambre Syndicale des Maîtres Artisans, the Comité d'Entente des Grands Groupements Commerciaux, the Fédération Départementale des Syndicats Médicaux, the Syndicats Agricoles de la Fédération Languedoc-Gascogne, and the Union des Propriétaires.

217 L'Action contribuable, 1 August 1938.

218 Ibid.

219 L'Action contribuable, October and November 1938. Lemaigre Dubreuil purchased the major Paris daily newspaper Le Jour-Écho de Paris in July 1939 which continued to follow a tough anti-German line in foreign policy until the outbreak of war.

220 Lemaigre Dubreuil, 'Entre la guerre et l'esclavage,' L'Action contribuable, April 1939.

221 See Lemaigre Dubreuil to Minister of Foreign Affairs Georges Bonnet, 25 August 1939 (Lemaigre Dubreuil Papers).

222 Lemaigre Dubreuil to the presidents of the local taxpayer groups, 26 and 28 September 1939 (Lemaigre Dubreuil Papers). He resigned from the Bank of France on 6 September 1940.

\section{France's fall and the Vichy change}

1 In 1939, Georges Lesieur et ses Fils had capital assets of 52 million francs and employed 800 workers, all at the Dunkirk plant. The conservative Le Jour-Écho de Paris had a daily circulation of 155,000 copies. This chapter is based on a revised and expanded version of 'The Struggle for Economic Influence in Southeastern Europe: The French Failure in Romania, 1940,' Journal of Modern History, 43, no. 3 (September 1971), pp. 468-82.

2 'Attributions du capitaine Lemaigre Dubreuil,' n.d. (Lemaigre Dubreuil Papers, Paris).

3 Léon Wenger, 55 ans de pétrole, 1904-1959: Souvenirs de Léon Wenger (Paris, 1968), pp. 110-11; Kuisel, Ernest Mercier, pp. 26-7.

4 Kuisel, Ernest Mercier, p. 126.

5 League of Nations, Statistical Yearbook of the League of Nations 1940/1941 (Geneva, 1941), p. 128; League of Nations, World Economic Survey 1939/1941 (Geneva, 1941), p. 242.

6 W. N. Medlicott, The Economic Blockade, 2 vols. (London, 1952, 1959), 1, p. 250; Léon Wenger, La Participation française dans la recherche et la production du pétrole (Paris, 1943), p. 41; Norman L. Forter and Demeter B. Rostovsky, The Roumanian Handbook (London, 1931), p. 172.

7 League of Nations, International Trade Statistics (Geneva, various years), for 1934, p. 238; for 1935, p. 238; for 1936, p. 239; for 1937, p. 310; for 1938, p. 225.

8 Allan G.B. Fisher, 'World Economic Affairs,' in Survey of International Affairs, 1938, Arnold J. Toynbee, ed., 3 vols. (London, 1941, 1951, 1953), 1, p. 61. Also see 'Germany's Trade Drive,' in League of Nations, World Economic Survey 1938/1939 (Geneva, 1939), pp. 199-206; Dietrich Orlow, The Nazis in the Balkans: A Case Study of Totalitarian Politics (Pittsburgh, 1968), pp. 5-13; Heinz Lucas, Die Deutsch-Rumänischen Wirtschaftsbeziehungen in neuerer Zeit (Würzburg, 1940); Martin Broszat, 'Deutschland-Üngarn-Rumänien, Entwicklung und Grundfaktoren nationalsozialistischen 


\section{The assassination of Jacques Lemaigre Dubreuil}

Hegemonial-und Bündnispolitik 1938-1941,' Historische Zeitschrift, 206 (February 1968), pp. 45-96.

9 Wenger, La participation française, p. 40.

10 Grigore Gafencu, Prelude to the Russian Campaign (London, 1945), pp. 256-7.

11 Lemaigre Dubreuil to Rigault, 14 February 1940 (Lemaigre Dubreuil's emphasis); Lemaigre Dubreuil, 'Compte-rendu d'un incident survenu le 15 février 1940 entre le capitaine Lemaigre Dubreuil affecté au Bureau de l'attaché militaire de Bucharest et Monsieur Sarret, attaché commercial de France à Bucharest,' 17 February 1940 (both in Lemaigre Dubreuil Papers).

12 Lemaigre Dubreuil to Rigault, 14 February 1940.

13 Lemaigre Dubreuil, 'Situation économique de la Roumanie,' 25 February 1940 (Lemaigre Dubreuil Papers), Lemaigre Dubreuil's emphasis. Also see Barry Crosby Fox, 'German Relations with Romania, 1933-1944,' (Ph.D. dissertation, Western Reserve University, 1964), pp. 73, 76; Henry L. Roberts, Rumania, Political Problems of an Agrarian State (New Haven, 1951), pp. 214-20; Antonin Basch, The Danube Basin and the German Economic Sphere (New York, 1943), pp. 213-15; Orlow, The Nazis in the Balkans, pp. 100-2; Wilhelm Treue, 'Das Dritte Reich und die Westmächte auf dem Balkan, zur Struktur der Aussenhandelspolitik Deutschlands, Grossbritanniens und Frankreichs 1933-1939,' Vierteljahrshefte für Zeitgeschichte, 1 (1953), pp. 45-64; and Martin Thomas, 'To Arm an Ally: French Arms sales to Romania, 1926-1940, The Journal of Strategic Studies, 19, no. 2 (June 1996), pp. 231-59.

14 Wohlthat to the Foreign Ministry, 14 February 1939, in Documents on German Foreign Policy, 1918-1945, Series D (1937-45), 13 vols. (Washington, 1949-83), 5, p. 393.

15 Lemaigre Dubreuil, 'Situation économique de la Roumanie.'

16 New York Times, 22 and 23 December 1939.

17 The Legation in Romania to the Foreign Ministry, 14 December 1939, in Documents on German Foreign Policy, 1918-1945, 8, pp. 530-1.

18 Lemaigre Dubreuil, 'Situation économique de la Roumanie.'

19 Lemaigre Dubreuil to de Mierry, 28 February 1940 (Lemaigre Dubreuil Papers).

20 General Maxime Weygand, 'Note relative à une intervention alliée dans les Balkans,' 9 December 1939 (Lemaigre Dubreuil Papers); Maxime Weygand, Mémoires, 3 vols. (Paris, 1950-57), 1, pp. 12-13.

21 Weygand, 'Note relative à une intervention alliée.'

22 Lemaigre Dubreuil to Paul Lesieur, 8 March 1940 and to Rigault, 15 March 1940 (both in Lemaigre Dubreuil Papers).

23 Lemaigre Dubreuil to Paul Lesieur, 15 and 18 March 1940; and to Colonel Joseph de Mierry, 15 March 1940 (all in Lemaigre Dubreuil Papers).

24 Wenger, 55 ans de pétrole, pp. 128, 131-3, 159-63, 185.

25 Jacques Lemaigre Dubreuil, 'Politique du pétrole en Roumanie,' 21 March 1940 and 'Rapport du capitaine Lemaigre Dubreuil sur la politique pétrolifère de la France en Roumanie,' February-March 1940 (both in Lemaigre Dubreuil Papers).

26 'Rapport de M. Léon Wenger, expert délégué par le gouvernement français sur la destruction de l'industrie pétrolière en Roumanie: extrait,' 1 October 1939, in Armée, État-major, Les Documents secrets de l'État-major général français, Deutsche Weissbuch des Auswärtigen Amtes, no. 6 (Berlin, 1941), pp. 32-3; 'Le général commandant en chef Gamelin à $\mathrm{M}$. le président du conseil, ministre de la défense nationale et de la guerre,' 18 October 1939, in Les Documents secrets de l'État-major général français, p. 35; Andreas Hillgruber, Hitler, König Carol und Marschall Antonescu, die deutsch-rümanischen Beziehungen, 1938-1944 (Wiesbaden, 1954), p. 65; Wenger, 55 ans de pétrole, pp. 195-6.

27 Lemaigre Dubreuil, 'Politique du pétrole en Roumanie.'

28 After 1 January 1940 French and British oil companies in Romania refused to sell petroleum to Germany. Between September and December 1939 after prodding by the 
Romanian government they had filled some orders. See New York Times, 19 April and 28 May 1940. In 1941 the Société Financière Belge des Pétroles was forced to sell Concordia to German interests. At the Liberation four Belgian administrators of the Société Financière Belge des Pétroles, who had also served on Concordia's board of directors, were placed under house arrest. One of them was subsequently released for acts of resistance during the Occupation, but the other three remained imprisoned until their deaths. See Wenger, 55 ans de pétrole, pp. 223-4.

29 Lemaigre Dubreuil, 'Politique du pétrole en Roumanie.'

30 The Société Générale des Huiles de Pétrole was founded in 1921 as a joint venture between the Anglo-Persian Oil Company (later the Anglo-Iranian Oil Company), Maison Paix et Cie., Georges Lesieur et ses Fils, and a common branch of the latter two firms, the Compagnie Occidentale des Produits du Pétrole. See Henry Peyret, 'Les Pétroles,' in Jacques Boudet, ed., Le Monde des affaires en France de 1830 à nos jours (Paris, 1952), pp. 213-14.

31 Je suis partout, 22 January 1943.

32 See 'Titres et qualités de M. Adrien Thierry, ambassadeur de France' (enclosure in letter from Jacques Thierry, son of the ambassador, to author). Thierry's L'Angleterre au temps de Paul Cambon (Paris, 1961) appeared in the year he died.

33 Weygand to Gamelin, 27 March 1940 (Lemaigre Dubreuil Papers).

34 Lemaigre Dubreuil, 'Renseignements pour M. le général Weygand, objet: modification de la politique de la France à l'égard de la Roumanie,' 1 April 1940 (Lemaigre Dubreuil Papers).

35 Lemaigre Dubreuil, 'Roumanie - question du pétrole,' 3 April 1940 (Lemaigre Dubreuil Papers). The Germans were having more difficulty than Lemaigre Dubreuil imagined securing Romania's oil. See Documents on German Foreign Policy, 19181945, 8, pp. 589-603, 615-17, 661 and Hermann Neubacher, Sonderauftrag Südost, 1940-1945, Bericht eines fliegenden Diplomaten (Göttingen, 1956).

36 Lemaigre Dubreuil, 'Le problème roumain,' 7 April 1940 (Lemaigre Dubreuil Papers).

37 Lemaigre Dubreuil to Robert Fel, assistant to the French naval attaché at Bucharest, 8 April 1940 (Lemaigre Dubreuil Papers). For the official appointment, see Weygand to Gamelin, 17 April 1940 (Lemaigre Dubreuil Papers).

38 Weygand, 'Note relative à une politique alliée dans les Balkans,' 9 April 1940 (Lemaigre Dubreuil Papers).

39 Ibid.

40 Lemaigre Dubreuil to Fel, 15 April 1940 and to Henry Pagesy, director of mines, Ministry of Public Works, 24 April 1940; Lemaigre Dubreuil, 'Note de renseignements pour le général Weygand,' 13, 16, and 19 April 1940 (all in Lemaigre Dubreuil Papers).

41 Lemaigre Dubreuil, 'Note de renseignements pour le général Weygand,' 26 April 1940.

42 Lemaigre Dubreuil, 'Note de renseignements pour le général Weygand,' 16 and 30 April and 8 May 1940 (Lemaigre Dubreuil Papers).

43 Wenger, 55 ans de pétrole, p. 198.

44 Lemaigre Dubreuil, 'Note de renseignements pour le général Weygand,' 11 May 1940; Lemaigre Dubreuil's 'Note remise par le capitaine Lemaigre Dubreuil au Ministère des Affaires Étrangères,' 15 May 1940 summarized his efforts to obtain government commitments on the Romanian proposals (both in Lemaigre Dubreuil Papers).

45 'Le Jour-Écho de Paris: Situation morale et juridique,' 27 December 1940 (Lemaigre Dubreuil Papers) and Jean-Camille Fernand-Laurent, Un peuple ressuscite (New York, 1943), pp. 198-200.

46 Le Jour-Écho de Paris, 13, 14, 15, and 16 June 1941; Fernand-Laurent, Un peuple ressuscite, pp. 196-7.

47 Lemaigre Dubreuil to Louis de Chappedelaine, 24 August 1940 and Goury du Roslan 


\section{The assassination of Jacques Lemaigre Dubreuil}

to Louis de Chappedelaine, 24 August 1940 (both in Lemaigre Dubreuil Papers).

48 Lemaigre Dubreuil, 'Note pour le général Weygand sur un journal d'empire,' 24 December 1940 (Lemaigre Dubreuil Papers).

49 Fernand-Laurent, Un peuple ressuscite, pp. 200-1; Simon Arbellot, La Presse française sous la francisque (Paris, 1952), pp. 27-8.

50 Lemaigre Dubreuil to Weygand, 5 July 1940 (Lemaigre Dubreuil Papers); MarocPresse, 13 June 1955.

51 Lemaigre Dubreuil to Weygand, 5 July 1940.

52 Société Georges Lesieur et ses Fils, L'Usine de Couderkerque-Branche et l'occupation allemande (n.p., 1944); Société Georges Lesieur et ses Fils, De Dunkerque à Dakar, 1940-1950 (Paris, 1950); Société Georges Lesieur et ses Fils, Historique, (n.p., n.d.), all in Lemaigre Dubreuil Papers.

53 See Pierre Nicolle, Cinquante mois d'armistice, 2 vols. (Paris, 1947), 1, pp. 98-9.

54 Lesieur, Historique.

55 'Rapport de Monsieur Wilvoski au juge d'instruction,' 31 July 1946 (Lemaigre Dubreuil Papers). This report, made by a financial expert attached to the Tribunal Civil de la Seine, was part of a larger investigation of wartime Lesieur operations initiated by the National Resistance Council.

56 'Statement by Lesieur lawyers in a legal case before the Tribunal Correctionnel de la Seine charging defamation against the president of the Tribunal de Commerce de Marseille,' 17 October 1945 (Lemaigre Dubreuil Papers).

57 'Statement by Lesieur lawyers,' 17 October 1945 and Paul Lesieur to the judicial commission of the National Resistance Council, 19 December 1944 (Lemaigre Dubreuil Papers).

58 René Durnerin, avocat au Conseil d'État, 'Mémoire,' 19 December 1944. This memorandum was written at Lemaigre Dubreuil's request to document Lesieur's economic activities during the war as well as the company's working relationship with both Vichy and German authorities.

59 'Statement by Lesieur lawyers,' 17 October 1945. See the series of articles in La Vie industrielle in June 1941 and the article in the Berliner Borsen Zeitung, 9 April 1942.

60 Paul Lesieur to the judicial commission of the National Resistance Council, 19 December 1944 and 'Rapport de Monsieur Wilvoski au juge d'instruction,' 31 July 1946. For the Wiesbaden accords on vegetable oil, see La Délégation française auprès de la commission allemande d'armistice, Recueil de documents publiés par le gouvernement français, 5 vols. (Paris, 1947-59), 2, pp. 160, 263.

61 Lesieur, L'Usine de Couderkerque-Branche et l'occupation allemande and Lesieur, De Dunkerque à Dakar.

62 Lemaigre Dubreuil to Marshal Philippe Pétain, 21 June 1941 (Lemaigre Dubreuil Papers).

\section{Defending French Africa}

1 For the defeat, see Jeffrey A. Gunsburg, Divided and Conquered: The French High Command and the Defeat of the West, 1940 (Westport, 1979). For the armistice and Vichy collaboration, see Robert O. Paxton, Vichy France: Old Guard and New Order, 1940-1944 (New York, 1972). For North Africa and the war, see William A. Hoisington, Jr., The Casablanca Connection: French Colonial Policy, 1936-1943 (Chapel Hill, 1984) and Christine Levisse-Touzé, L'Afrique du Nord dans la guerre, 1939-1945 (Paris, 1998).

2 On Mers-el-Kébir and Dakar, see Eleanor M. Gates, End of the Affair: The Collapse of the Anglo-French Alliance, 1939-40 (Berkeley, 1981) and Arthur J. Marder, Operation 'Menace:' The Dakar Expedition and the Dudley North Affair (London, 1976). On Gaullism and the empire, see Jean Lacouture, De Gaulle, 3 vols. (Paris, 1984-86). On England and Vichy, see R.T. Thomas, Britain and Vichy: The Dilemma of AngloFrench Relations, 1940-42 (New York, 1979). 
3 On Weygand in North Africa, see Maxime Weygand, Mémoires, 3 vols. (Paris, 1950-57).

4 See Julian G. Hurstfield, America and the French Nation, 1939-1945 (Chapel Hill, 1986) and William L. Langer, Our Vichy Gamble (New York, 1947).

5 Langer, Our Vichy Gamble, p. 262 and Robert D. Murphy, Diplomat Among Warriors (Garden City, 1964), chapter 5. On Roosevelt and the French, see André Kaspi, Franklin D. Roosevelt (Paris, 1988) and Mario Rossi, Roosevelt and the French (Westport, 1993). On the Murphy-Weygand Agreement of 26 February 1941, see James J. Dougherty, The Politics of Wartime Aid: American Economic Assistance to France and NorthWest Africa, 1940-1946 (Westport, 1978).

6 See Murphy, Diplomat Among Warriors, pp. 116-17.

7 Philip C.F. Bankwitz, Maxime Weygand and Civil-Military Relations in Modern France (Cambridge, 1967), p. 328. On the Armée d'Afrique, see Louis Berteil, L'Armée de Weygand: La Chance de la France, 1940-1942 (Paris, 1975) and Anthony Clayton, France, Soldiers and Africa (London, 1988).

8 André Beaufre, La Revanche de 1945 (Paris, 1966), pp. 68, 74, 79. Also see Beaufre, Mémoires, 1920-1940-1945 (Paris, 1965).

9 Lemaigre Dubreuil to Minister of Justice Joseph Barthélemy (with a copy to General Weygand), 29 August 1941 (Lemaigre Dubreuil Papers).

10 Lemaigre Dubreuil to Pierre Laval, 29 August 1941 (Lemaigre Dubreuil Papers). Laval was dismissed as deputy premier in December 1940, then re-appointed 14 months later in April 1942 at German urging.

11 For Lemaigre Dubreuil's final conversation with Weygand on 13 November 1941, see his recollections in Crusoé [Lemaigre Dubreuil], Vicissitudes d'une victoire (Paris, 1946), pp. 17-19 and [Lemaigre Dubreuil], La Rentrée en guerre de la France africaine aux côtés des Alliés, le 8 novembre 1942 (Paris, 1944), pp. 9-10. Robinson Crusoe (Crusoé or Crusoë in French) was the code name for Lemaigre Dubreuil in U.S. intelligence messages; Lemaigre Dubreuil's close associate, Jean Rigault, was appropriately tagged Friday (Vendredi). La Rentrée en guerre reproduces articles that first appeared in the North African weekly T.A.M. (Tunisie-Algérie-Maroc), nos. 49 and 50, published in Algiers in May-June 1943.

12 Memorandum by the Counselor of Embassy in France (Murphy), Temporarily at Algiers, 5 December 1941, in the Counselor of Embassy in France (Murphy), Temporarily at Algiers, to the the Under Secretary of State (Sumner Welles), 7 December 1941, Foreign Relations of the United States (hereafter FRUS), 1941 (Washington, 1959), 2, pp. 495-6.

13 Murphy Memorandum, 5 December 1941, FRUS, 1942 (Washington, 1962), 2, p. 496.

14 'Note de Monsieur Rigault sur le débarquement anglo-américain en Afrique du Nord, le 8 novembre 1942,' n.d., pp. 15-16 (Lemaigre Dubreuil Papers). This is Rigault's detailed account of the activities of the Five from December 1941 to November 1942.

15 See the Counselor of Embassy in France (Murphy) to the Under Secretary of State (Welles), 12 January 1942 and enclosures, in FRUS, 1942, 2, pp. 229-36. Rigault wrote the political notes and Colonel Louis Jousse prepared the military one.

16 FRUS, 1942, 2, pp. 232-3.

17 The Counselor of Embassy in France (Murphy) to the Adviser on Political Relations (James C. Dunn), 9 January 1942, in FRUS, 1942, 2, pp. 227-8.

18 Quoted in Langer, Our Vichy Gamble, p. 233.

19 Memorandum by the Assistant Chief of Staff, War Department (Eisenhower), 25 February 1942, in FRUS, 1942, 2, pp. 258-9. Also see the Counselor of Embassy in France (Murphy) to the Acting Chief of the Division of European Affairs (Ray Atherton), 6 July 1942, in FRUS, 1942, 2, p. 331.

20 'Note de Monsieur Rigault sur le débarquement anglo-américain en Afrique du Nord,' p. 40 and Lemaigre Dubreuil, 'Historique des relations franco-américaines, Alger, 1940-1943,' (Lemaigre Dubreuil Papers), p. 12. This is the longer manuscript version 


\section{The assassination of Jacques Lemaigre Dubreuil}

of Lemaigre Dubreuil's Les Relations franco-américaines et la politique des généraux, Alger 1940-1943 (Paris, 1949).

21 For the military report, also prepared by Colonel Jousse, see FRUS, 1942, 2, pp. 266-71.

22 The Counselor of Embassy in France (Murphy) to the Under Secretary of State (Welles), 14 March 1942, in FRUS, 1942, 2, pp. 263-5.

23 The Consul General at Algiers (Felix Cole) to the Secretary of State (Cordell Hull) [from Murphy to Welles], 2 April 1942; The Acting Secretary of State (Welles) to the Consul General at Algiers (Cole) [for Murphy], 16 and 18 April 1942, all in FRUS, 1942, 2, pp. 278-9, 284.

24 The Consul General at Algiers (Cole) to the Secretary of State [Personal for the Acting Secretary from Murphy], 18 April 1942, in FRUS, 1942, 2, pp. 285-7.

25 [The Committee of Five], 'Note destinée à Monsieur le Délégué-Général des ÉtatsUnis en Afrique,' 1 May 1942 (Lemaigre Dubreuil Papers) and Lemaigre Dubreuil, 'Historique des relations franco-américaines,' pp. 14-15.

26 The Consul General at Algiers (Cole) to the Secretary of State [For the Under Secretary from Murphy], 3 May 1942, in FRUS, 1942, 2, pp. 293-4.

27 The Consul General at Algiers (Cole) to the Secretary of State [For the Under Secretary from Murphy], 6 May 1942, in FRUS, 1942, 2, pp. 298-9.

28 The Consul General at Algiers (Cole) to the Secretary of State [From Murphy], 6 May 1942 , in FRUS, 1942, 2, pp. 297-8. For Giraud's escape, see Henri-Honoré Giraud, Mes Évasions (Paris, 1951). On Giraud himself, see the general's frank memoirs published after his death, Un seul but, la victoire. Alger 1942-1944 (Paris, 1949) and Arthur Layton Funk, The Politics of TORCH: The Allied Landings and the Algiers Putsch, 1942 (Lawrence, 1974), pp. 45-9. Lemaigre Dubreuil thought it somewhat contradictory for the American democracy to be so focused on a 'great man' as the leader of any anti-German resistance rather than on the resistance groups themselves. See [Lemaigre Dubreuil], La Rentrée en guerre de la France africaine, p. 14.

29 Cruosé, Vicissitudes d'une victoire, pp. 25-6; Lemaigre Dubreuil, 'Historique des relations franco-américaines,' pp. 15-16; [Lemaigre Dubreuil], La Rentrée en guerre de la France africaine, pp. 15-16; and the Consul General at Algiers (Cole) to the Secretary of State [For Atherton from Murphy], 8 July 1942, in FRUS, 1942, 2, pp. 333-4.

30 The Consul General at Algiers (Cole) to the Secretary of State [For the Under Secretary from Murphy], 6 May 1942, in FRUS, 1942, 2, pp. 298-300. On Madagascar, see Martin Thomas, The French Empire at War, 1940-45 (Manchester, 1998), pp. 139-54.

31 Lemaigre Dubreuil, 'Historique des relations franco-américaines,' pp. 17-18; [Lemaigre Dubreuil], La Rentrée en guerre de la France africaine, pp. 16-17; 'Note de Monsieur Rigault sur le débarquement anglo-américain en Afrique du Nord,' pp. 42, 63-70. Also see the Counselor of Embassy in France (Murphy) to the Acting Chief of the Division of European Affairs (Atherton), 6 July 1942, in FRUS, 1942, 2, pp. 331-2. For Mast, see Charles Mast, Histoire d'une rébellion. Alger, 8 novembre 1942 (Paris, 1969) and for Béthouart, see Antoine-Émile Béthouart, Cinq années d'espérance. Mémoires de guerre, 1939-1945 (Paris, 1968). For a summary and assessment of Giraud's plans, see Funk, The Politics of TORCH, pp. 58-64.

32 'Procès-verbal des conversations tenues avec MM. Solborg et Murphy,' n.d. [15 June 1942] and 'Aide-mémoire remis à M. Solborg en juin 1942 avant son départ d'Alger pour la Maison Blanche,' both in Lemaigre Dubreuil Papers; 'Note de Monsieur Rigault sur le débarquement anglo-américain en Afrique du Nord,' pp. 42-4; [Lemaigre Dubreuil], La Rentrée en guerre de la France africaine, pp. 17-19. Also see Funk, The Politics of TORCH, pp. 53-8

33 The Consul General at Algiers (Cole) to the Secretary of State [For Ray Atherton from Murphy], 8 July 1942, in FRUS, 1942, 2, pp. 333-4; [Lemaigre Dubreuil], 'Historique des relations franco-américaines,' p. 19; and Lemaigre Dubreuil to Solborg, 30 June 1942 (Lemaigre Dubreuil Papers).

34 Lemaigre Dubreuil to Giraud, 4 July 1942 and 'Copie d'une déclaration faite 
conjointement par le général Mast et Monsieur Lemaigre Dubreuil le 20 juillet 1942 et remise par écrit à M. Murphy' (both in Lemaigre Dubreuil Papers) and Albert Kammerer, Du Débarquement africain au meurtre de Darlan (Paris, 1949), p. 113.

35 'Copie d'un télégramme envoyé le 21 juillet 1942 par M. Lemaigre Dubreuil au Colonel Solborg par l'intermédiaire de M. Murphy' (Lemaigre Dubreuil Papers) and 'Note de Monsieur Rigault sur le débarquement anglo-américain en Afrique du Nord,' pp. 45-6.

36 See Langer, Our Vichy Gamble, pp. 307-8. On the pre-history of TORCH, see Funk, The Politics of TORCH, especially chapters 2 and 4.

37 Directive by President Roosevelt to Mr. Robert D. Murphy, 22 September 1942, in FRUS, 1942, 2, pp. 379-81 and Lemaigre Dubreuil to Major Guy Grout de Beaufort, 6 November 1942 (Lemaigre Dubreuil Papers). On Murphy in Washington, see Funk, The Politics of TORCH, pp. 100-2. If Vichy broke relations with the United States at the time of the landings, the Five believed they would head up an independent North African government, recognized by the Allies. But Roosevelt had no intention of doing this. For Roosevelt's North Africa policy and TORCH directives, see Funk, The Politics of TORCH, pp. 113-21.

38 Lemaigre Dubreuil, 'Memorandum re: July-November 1942,' May 1943 (Lemaigre Dubreuil Papers); The Chargé in France (S. Pinkney Tuck) to the Secretary of State [For Atherton], 23 August 1942 and the Consul General at Algiers (Cole) to the Secretary of State [For Murphy], 29 September 1942, both in FRUS, 1942, 2, pp. 362, 383-4; Lemaigre Dubreuil, 'Historique des relations franco-américaines,' pp. 21-2.

39 The Secretary of State to the Consul General at Algiers (Cole) [For Cole from Murphy], 30 September 1942, in FRUS, 1942, 2, p. 385.

40 Crusoé, Vicissitudes d'une victoire, p. 32.

41 The Consul General at Algiers (Cole) to the War Department, undated [12 or 13 October 1942], in FRUS, 1942, 2, pp. 392-4. Murphy also had confidential visits from Major André Dorange, the representative of General Alphonse Juin, Commander-inChief of all French forces in North Africa and Darlan's subordinate, who asked similar questions about American aid to North Africa, should Juin decide to resist Axis aggression. See the Consul General at Algiers (Cole) to the War Department [From Murphy], 20 October 1942, in FRUS, 1942, 2, pp. 398-400.

42 The Consul General at Algiers (Cole) to the War Department [From Murphy. For Leahy], 15 [or 14] October 1942, in FRUS, 1942, 2, pp. 394-6. Also see Funk, The Politics of TORCH, pp. 132-6.

43 Admiral William D. Leahy, Chief of Staff to the Commander-in-Chief of the Army and Navy, to the Consul General at Algiers (Cole) [From General Thomas T. Handy, Chief of Operations Division, War Department for Murphy], 17 October 1942, in FRUS, 1942, 2, pp. 396-7.

44 [Lemaigre Dubreuil], La Rentrée en guerre de la France africaine, p. 23 and Crusoé, Vicissitudes d'une victoire, p. 34.

45 For the Murphy-Giraud Agreement and enclosures, see the American Political Adviser at Algiers (Murphy) to the Secretary of State, 22 March 1943, in FRUS, 1942, 2, pp. 412-22. For Lemaigre Dubreuil's summary of the Agreement, see Crusoé, Vicissitudes d'une victoire, pp. 33-4. For Roosevelt and the Agreement, see Joint Chiefs of Staff, Minutes of a Meeting at the White House, 7 January 1942, in FRUS, The Conferences at Washington, 1941-1942 and Casablanca, 1943 (Washington, 1968), p. 514. Also see Funk, The Politics of TORCH, pp. 136-8, 144-6.

46 On the Cherchell meeting, see the summary and assessment in Funk, The Politics of TORCH, chapter 7. For Lemaigre Dubreuil on Cherchell, see Crusoé, Vicissitudes d'une victoire, pp. 35-7.

47 General Henri Giraud to the Presonal Representative of President Roosevelt (Murphy), 'Agreement in Principle,' 27 October 1942, in FRUS, 1942, 2, pp. 419-22 and [Lemaigre Dubreuil], La Rentrée en guerre de la France africaine, pp. 25-6. Also 


\section{The assassination of Jacques Lemaigre Dubreuil}

see Funk, The Politics of TORCH, pp. 167-9. The original French text of Giraud's 'Accord de principe' is in Giraud, Un seul but, la victoire, pp. 342-5.

48 See the Personal Representative of President Roosevelt (Murphy) to General Henri Giraud, 2 November 1942, in FRUS, 1942, 2, pp. 416-17.

49 Murphy, Diplomat Among Warriors, p. 121.

50 See Funk, The Politics of TORCH, pp. 39, 136, 166.

51 The Consul General at Algiers (Cole) to the War Department [From Murphy. Personal for Leahy to be communicated immediately.], 31 October 1942, in FRUS, 1942, 2, pp. 409-10; Lemaigre Dubreuil to Robert Murphy, 2 November 1942 (Lemaigre Dubreuil Papers); [Lemaigre Dubreuil], La Rentrée en guerre de la France africaine, pp. 27-8; and Crusoé, Vicissitudes d'une victoire, pp. 41-4. Also see Funk, The Politics of TORCH, pp. 180-1.

52 The Consul General at Algiers (Cole) to the War Department [From Murphy. Personal for Leahy to be communicated immediately.], 31 October 1942 and Admiral William D. Leahy, Chief of Staff to the Commander-in-Chief of the Army and Navy, to the Consul General at Algiers (Cole) [This message for Murphy.], 2 November 1942, both in FRUS, 1942, 2, pp. 409-10, 423. Also see Murphy to Lemaigre Dubreuil, 6 November 1942 (Lemaigre Dubreuil Papers).

53 Crusoé, Vicissitudes d'une victoire, p. 47 and [Lemaigre Dubreuil], La Rentrée en guerre de la France africaine, p. 28. Also see Funk, The Politics of TORCH, pp. 184-5.

54 Robinson Crusoe [Lemaigre Dubreuil] to [Giraud], 5 November 1942 (Lemaigre Dubreuil Papers).

55 Eisenhower to Marshall, 7 November 1942 and Eisenhower to Combined Chiefs of Staff, 8 November 1942 (three letters), all in Dwight D. Eisenhower, The Papers of Dwight David Eisenhower: The War Years, 5 vols. ed. Alfred D. Chandler (Baltimore, 1970), 2, pp. 668-76. Also see Funk, The Politics of TORCH, pp. 177-8, 182-3, 18891, 227-30; Giraud, Un seul but, la victoire, pp. 22-7; and Giraud, Mes Évasions, pp. 147-51. Lemaigre Dubreuil had thought it 'indispensable' that Giraud come directly to Algiers on the night of 6-7 November in order to calm 'certain nervous feelings' and to sign personal letters to the bey of Tunis and the sultan of Morocco rather than go first to Gibraltar. But this did not happen. See Robinson Crusoe to [Giraud], 5 November 1942.

56 For the Blida episode, see [Lemaigre Dubreuil], La Rentrée en guerre de la France africaine, pp. 34-6.

57 [Lemaigre Dubreuil], La Rentrée en guerre de la France africaine, p. 37.

58 See Hoisington, The Casablanca Connection, especially chapters 7 and 8.

59 Crusoé, Vicissitudes d'une victoire, pp. 56-7 and Murphy, Diplomat Among Warriors, pp. 124-5.

60 The Consul General at Algiers (Cole) to the War Department [From Murphy. For Leahy.], undated [Received 5 November 1942], in FRUS, 1942, 2, p. 425.

61 General Mark W. Clark, 'Record of Events and Documents from the date that Lieutenant General Mark W. Clark entered into negotiations with Admiral Jean François Darlan until Darlan was assassinated on Christmas Eve, 1942,' 22 February 1943, pp. 2-3 (Mark W. Clark Papers, Charleston, South Carolina).

62 Clark, 'Record of Events,' pp. 13-15.

63 See Clark, 'Record of Events,' p. 19.

64 Clark, 'Record of Events,' p. 36.

65 Clark, 'Record of Events,' pp. 43-4. On Noguès, see Hoisington, The Casablanca Connection, pp. 236-7. For Darlan and Lemaigre Dubreuil, see Hervé Coutau-Bégarie and Claude Huan, Darlan (Paris, 1989), p. 615, quoting the unpublished memoirs of General Jean Chrétien.

66 Crusoé, Vicissitudes d'une victoire, p. 55. Giraud insisted that his delay in reaching Algiers was due to the Americans. See Giraud, Un seul but, la victoire, pp. 21-2. 


\section{Working for Giraud}

1 [Jacques Lemaigre Dubreuil], 'Le Coup d'état du 8 novembre 1942,' 28 November 1942 (Lemaigre Dubreuil Papers).

2 Funk, The Politics of TORCH, pp. 251-2. On the furore over the 'Darlan deal,' see Hurstfield, America and the French Nation, chapter 8.

3 [Lemaigre Dubreuil], 'Le Coup d'état du 8 novembre 1942,' and Lemaigre Dubreuil, Les Relations franco-américaines et la politique des généraux, p. 34. On the ClarkDarlan Agreement, see Agreement Between General Mark Clark and Admiral François Darlan, Signed at Algiers, November 22, 1942, in FRUS, 1942, 2, pp. 453-7 and Funk, The Politics of TORCH, chapter 11.

4 Crusoé, Vicissitudes d'une victoire, p. 65.

5 [Jacques Lemaigre Dubreuil], 'Début novembre 1942: débarquement allié; début juin 1943: arrivée en Afrique du Nord du général de Gaulle,' n.d., p. 17 (Lemaigre Dubreuil Papers); Lemaigre Dubreuil, 'Historique des relations franco-américaines,' p. 36; and [Lemaigre Dubreuil], 'Le Coup d'état du 8 novembre 1942.' Also see Bégarie and Huan, Darlan, pp. 631-2, 652.

6 Clark, 'Record of Events,' pp. 49, 60.

7 [Jacques Lemaigre Dubreuil], 'Bilan de la situation 20 jours après le coup d'état du 8 novembre' (Lemaigre Dubreuil Papers). On the Darlan government, see the positive assessments of Coutau-Bégarie and Huan, Darlan, chapter 20 and George E. Melton, Darlan: Admiral and Statesman of France, 1881-1942 (Westport, 1998).

8 Lemaigre Dubreuil to Darlan, 27 November 1942 (Lemaigre Dubreuil Papers). Coutau-Bégarie and Huan term the letter 'rather insolent.' See Darlan, p. 652.

9 See 'Procès-verbal: Première réunion de l'amiral de la flotte et des résidents et gouverneurs généraux,' 30 November 1942 and 'Procès-verbal du Conseil Impérial, première réunion,' 30 November 1942 (both in Lemaigre Dubreuil Papers); and [Lemaigre Dubreuil], 'Début novembre 1942: débarquement allié,' pp. 18-20. For the press communiqué on the Imperial Council, see François Darlan, Lettres et notes de l'amiral Darlan [recueillies par] Hervé Coutau-Bégarie and Claude Huan (Paris, 1992), p. 595. On the American concern over the establishment of a French Imperial Federation, see Memorandum of Conversation, by the Assistant Chief of the Division of Near Eastern Affairs (Henry S. Villard), 3 December 1942, in FRUS, 1942, 2 , p. 471.

10 Rigault to Lemaigre Dubreuil, 3 December 1942 (Lemaigre Dubreuil Papers). On imperial federalism, see René Rodière, Législation de l'Afrique du nord en guerre, 8 novembre 1942-8 novembre 1943 (droit privé et droit criminel) (Algiers, La Maison des Livres, n.d. [1940-49]), pp. 9-10, 12-14.

11 See Darlan's declaration on the High Commissionership in Statement Issued to the Press by President Roosevelt, December 16, 1942, in FRUS, 1942, 2, pp. 482-3. On the organization of the High Commissionership, see Coutau-Bégarie and Huan, Darlan, pp. 650-62. According to the Journal officiel du Haut Commissariat, Darlan's complete title was 'Haut Commissaire de France résidant en Afrique Française.' He proclaimed himself 'head of state' over all the lands that had been under the rule of Marshal Pétain's government and that were not presently occupied by German troops. See Rodière, Législation de l'Afrique du nord en guerre, pp. 5-6.

12 'Procès-verbal: Première réunion de l'amiral de la flotte et des résidents et gouverneurs généraux,' 30 November 1942. On Darlan's political use of the MurphyGiraud Agreement, see 'Circulaire aux postes diplomatiques,' 5 December 1942, in Darlan, Lettres et notes de l'amiral Darlan, pp. 600-2.

13 Lemaigre Dubreuil to Giraud, 2 December 1942 and Giraud to Lemaigre Dubreuil, 'Note de service,' 3 December 1942, both in Lemaigre Dubreuil Papers.

14 [Lemaigre Dubreuil], 'Position politique du Haut Commissariat en Afrique française,' 15 December 1942 (Lemaigre Dubreuil Papers). Also see [Lemaigre Dubreuil], 'Note 


\section{The assassination of Jacques Lemaigre Dubreuil}

au sujet de la mobilisation des forces morales et materielles du pays,' 7 December 1942 (Lemaigre Dubreuil Papers).

15 [Lemaigre Dubreuil], 'Projet d'organisation gouvernementale,' 17 December 1942 (Lemaigre Dubreuil Papers).

16 Giraud to Lemaigre Dubreuil, 'Ordre de mission,' 10 December 1942 and Giraud, 'Note de service,' 10 December 1942, both in Lemaigre Dubreuil Papers. Also see Lemaigre Dubreuil to Captain André Beaufre, 7 December 1942 (Lemaigre Dubreuil Papers). Darlan approved the mission and wrote a letter of introduction to Admiral Leahy for Lemaigre Dubreuil. See Darlan, Lettres et notes de l'amiral Darlan, p. 626.

17 Clark, 'Record of Events,' pp. 92, 94; Eisenhower to Clark, 25 December 1942, in The Papers of Dwight David Eisenhower: The War Years, 2, pp. 860-1 and 'Décision du Conseil Impérial de l'Afrique Française,' 26 December 1942 (Noguès Papers). Giraud remembered the meeting of the Imperial Council where he was named to replace Darlan as 'one of the worst memories of [his] life.' Giraud, Un seul but, la victoire, pp. 79-80. Darlan's assassination was the work of a passionate university student, Fernand Bonnier de la Chapelle, who may have hoped that the admiral's death would pave the way for a royalist restoration. On the 'plots' to assassinate Darlan, see Coutau-Bégarie and Huan, Darlan, chapter 21 and Melton, Darlan, chapters 22 and 23, but especially Elmar Krautkrämer, Frankreichs Kriegswende 1942: die Rückwirkungen der alliierten Landung in Nordafrika: Darlan, de Gaulle, Giraud und die royalistsche Utopie (Bern, 1989) who wrongly targets Lemaigre Dubreuil as both a royalist and a plotter.

18 Crusoé, Vicissitudes d'une victoire, p. 90.

19 Memorandum of Conversation, by the Assistant Chief of the Division of European Affairs (Samuel Reber), 27 December 1942, in FRUS, 1942, 2, pp. 492-3.

20 Reber memorandum, 27 December 1942, and the Secretary of State to the Chargé in the United Kingdom (S. Freeman Matthews), 29 December 1942, in FRUS, 1942, 2, pp. 493, 495.

21 Press Release Issued by the Department of State, 28 December 1942 and Memorandum of Conversation, by the Assistant Chief of the Division of European Affairs, 28 December 1942, both in FRUS, 1942, 2, pp. 493-4.

22 The Under Secretary of State (Welles) to President Roosevelt with enclosed Suggested Instruction to General Eisenhower and to Mr. Murphy, 30 December 1942, in FRUS, 1942, 2, pp. 499-501.

23 President Roosevelt to the British Prime Minister (Winston S. Churchill), 1 January 1943, in FRUS, 1943, 2, p. 23.

24 The Chargé in the United Kingdom (Matthews) to the Secretary of State, 1 January 1943, in FRUS, 1943, 2, p. 24.

25 [Lemaigre Dubreuil], 'Note au sujet des négociations avec le Département d'État,' 8 January 1943 (Lemaigre Dubreuil Papers).

26 Memorandum of Conversation, by the Assistant Chief of the Division of European Affairs, 9 January 1943, in FRUS, 1943, 2, pp. 36-8.

27 Memorandum of Conversation, by the Assistant Chief of the Division of European Affairs, 11 January 1943, in FRUS, 1943, 2, pp. 38-9. For Lemaigre Dubreuil's account of the Washington meetings, see Crusoé, Vicissitudes d'une victoire, pp. 78-86; for his press statement at mission's end, see 'Déclaration à la presse de Washington de Monsieur Lemaigre Dubreuil,' 10 January 1943 (Lemaigre Dubreuil Papers).

28 Crusoé, Vicissitudes d'une victoire, p. 87.

29 See Eisenhower's summary of a cable from the State Department to Murphy (then in Casablanca) of what Lemaigre Dubreuil said he hoped to achieve, in the Commanderin-Chief, Allied Expeditionary Force in North Africa (Eisenhower) to the President's Personal Representative (Murphy), Algiers, 17 January 1943, in FRUS, Washington and Casablanca, pp. 812-14.

30 Roosevelt-Giraud Conversation, 17 January 1943, in FRUS, Washington and 
Casablanca, pp. 609-12 and The President to the Secretary of State, 18 January 1943, in FRUS, Washington and Casablanca, p. 816.

31 Hopkins-Harriman-Poniatowski Meeting, 19 January 1943, in FRUS, Washington and Casablanca, pp. 641-2. On Poniatowski, see Giraud, Un seul but, la victoire, p. 86.

32 Roosevelt-Giraud Conversation, 19 January 1943, in FRUS, Washington and Casablanca, pp. 644-6.

33 Roosevelt-Giraud Conversation, 19 January 1943, in FRUS, Washington and Casablanca, pp. 646-7.

34 Lemaigre Dubreuil to Jean Monnet, 21 January 1943 (Lemaigre Dubreuil Papers). Monnet had been Allied Chairman of the Anglo-French Coordinating Committee in London until the fall of France. Then he worked with the British Supply Mission in Washington and, after American entry into the war, with all of the combined supply boards.

35 See Crusoé, Vicissitudes d'une victoire, pp. 91-2 and Beaufre, La Revanche de 1945, p. 198. Although Giraud printed the Anfa Memorandum with the documents at the end of his memoirs, he made no mention of it at all in the text.

36 See the Consul General (Samuel H. Wiley) to the Secretary of State [For Atherton from Murphy], 1 February 1943, in FRUS, 1943, 2, pp. 44-6 and the President's Personal Representative (Murphy) to the Secretary of State, 1 February 1943, in FRUS, Washington and Casablanca, pp. 825-8. Also see Arthur Layton Funk, 'The "Anfa Memorandum": An Incident of the Casablanca Conference,' Journal of Modern History, 26, no. 3 (September 1954), pp. 246-54.

37 Haussaire [Haut Commissaire] à Mission française, Washington [Giraud to Béthouart], 26 January 1943, in Crusoé, Vicissitudes d'une victoire, pp. 145-6.

38 Crusoé, Vicissitudes d'une victoire, pp. 93-4.

39 See Crusoé, Vicissitudes d'une victoire, p. 94 and [Lemaigre Dubreuil], 'Quelques aspects de la politique extérieure et intérieure de la France extra-métropolitaine de 1940 à 1945,' pp. 136-7. According to Giraud, Lemaigre Dubreuil was shocked at his hostile reception by Fighting France militants in Washington. See Giraud, Un seul but, la victoire, pp. 104, 107.

40 For de Gaulle at Casablanca, see Arthur Layton Funk, Charles de Gaulle: The Crucial Years, 1943-1943 (Norman, 1959), pp. 73-5. For Giraud's perspective on de Gaulle and his team at Anfa, see Giraud, Un seul but, la victoire, pp. 101-11. For Gaullist antiLemaigre Dubreuil propaganda, see France Libre, 'Note sur l'activité de Monsieur Lemaigre Dubreuil antérieurement au débarquement allié en Afrique du Nord,' 4 February 1943, in the Lemaigre Dubreuil dossier at the Secrétariat Général du Gouvernement, Direction de la Documentation, Paris.

41 The President's Personal Representative (Murphy) to the Secretary of State, 1 February 1943, in FRUS, Washington and Casablanca, p. 826; Funk, Charles de Gaulle, pp. 80-1, 91-4; Crusoé, Vicissitudes d'une victoire, pp. 101-4; and Funk, 'Anfa Memorandum,' p. 252.

42 See the revised text in the Consul General at Algiers (Wiley) to the Secretary of State [For the Secretary and Under Secretary from Murphy], 6 February 1943, in FRUS, 1943, 2, pp. 48-51. Also see Funk, 'Anfa Memorandum,' pp. 251-3.

43 See Lemaigre Dubreuil to Rudolph d'Adler, 26 January 1943 (Lemaigre Dubreuil Papers) and 'Procès-verbal du Conseil Impérial,' 2, 3, and 4 February 1943 (Noguès Papers).

44 Lemaigre Dubreuil to Giraud, 6 February 1943, in Crusoé, Vicissitudes d'une victoire, p. 148.

45 See Giraud to Murphy, 10 February 1943, in Crusoé, Vicissitudes d'une victoire, pp. 149-50. Also see the Consul General at Algiers (Wiley) to the Secretary of State [For the Secretary and Under Secretary from Murphy], 9 February 1943; The Secretary of State to the Consul General at Algiers (Wiley) [For Murphy], 15 February 1943; and 


\section{The assassination of Jacques Lemaigre Dubreuil}

the Personal Representative of President Roosevelt in North Africa (Murphy) to the High Commissioner of French North Africa (Giraud), 19 February 1943, all in FRUS, 1943, 2, pp. 52-3, 58-9.

46 [Lemaigre Dubreuil], 'Note pour le Général Commandant en Chef,' 8 February 1943 (Lemaigre Dubreuil Papers).

47 Crusoé, Vicissitudes d'une victoire, p. 105.

48 'Compte-rendu d'un entretien entre le général Catroux et Monsieur Lemaigre Dubreuil,' 11 February 1943 (Lemaigre Dubreuil Papers). Catroux mentions his meeting with Lemaigre Dubreuil, but gives no details in Georges Catroux, Dans la bataille de Méditerranée, Égypte-Levant-Afrique du Nord, 1940-1944 (Paris, 1949). On Giraud's promise to Lemaigre Dubreuil, see Giraud, 'Ordre de mission pour le Délégué Général aux Affaires Inter-Alliées,' 9 February 1943 (Lemaigre Dubreuil Papers).

49 Lemaigre Dubreuil to Giraud, 5 March 1943 (Lemaigre Dubreuil Papers).

50 On Monnet and his mission, see André Kaspi, La Mission de Jean Monnet à Alger, mars-octobre 1943 (Paris, 1971). Also see Funk, Charles de Gaulle, pp. 105-6.

51 The Consul General at Algiers (Wiley) to the Secretary of State [Personal for the President and Secretary from Murphy], 4 March 1943, in FRUS, 1943, 2, pp. 67-70. On the speech, see the Consul General at Algiers (Wiley) to the Secretary of State [Personal for the President and the Secretary from Murphy], 14 March 1943, in FRUS, 1943, 2, pp. 71-3 and Funk, Charles de Gaulle, pp. 106-10.

52 See Robert Aron, Histoire de l'Épuration, 3 vols. (Paris, 1967-75), 1, p. 112.

53 See Lemaigre Dubreuil to Giraud, 26 March 1943 (Lemaigre Dubreuil Papers) and Le Figaro, 12 May 1949.

54 Lemaigre Dubreuil to Giraud, 29 March 1943 and [Lemaigre Dubreuil], 'Memorandum sur l'unité française,' 1 April 1943 (both in Lemaigre Dubreuil Papers).

55 See Funk, Charles de Gaulle, especially chapters 3, 4 and 5. Also see Martin Thomas, 'The Discarded Leader: General Henri Giraud and the Foundation of the French Committee of National Liberation,' French History, 10, no. 1 (1996), pp. 86-111.

56 Lemaigre Dubreuil to de Gaulle, May 1944 (Lemaigre Dubreuil Papers).

57 Lemaigre Dubreuil to H. Freeman Matthews, 15 June 1944 and 'Note de M. Lemaigre Dubreuil pour M. Matthews, directeur des Affaires Politiques d'Europe au Département d'État de Washington, en le priant de bien vouloir le communiquer à son Excellence M. le Secrétaire d'État Cordell Hull avec la déférente sympathie de son auteur,' [June 1944], both in Lemaigre Dubreuil Papers.

58 See Geoffrey Warner, Pierre Laval and the Eclipse of France (New York, 1968), pp. 393-6 for the German documents and François Piétri, Mes Années d'Espagne, 19401948 (Paris, 1954), pp. 244-50.

59 [Lemaigre Dubreuil], 'Situation politique intérieure de la France,' 5 October 1944 (Lemaigre Dubreuil Papers).

60 See Action, 14 and 28 December 1945 and 11 January 1946.

61 'Affaire Lemaigre Dubreuil-Rigault,' n.d.; 'Pour comprendre l'Affaire Lemaigre Dubreuil-Rigault,' n.d.; Premier Tribunal Militaire Permanent de Paris, 'Ordonnance de non-lieu,' 3 May 1945; Decree of the Minister of Finance, 27 June 1945, all in Lemaigre Dubreuil Papers.

62 See, for example, Lemaigre Dubreuil's letters to Philippe Barrès, managing director of Paris-Presse, 8 October 1945; to the editor of L'Aube, 25 March 1947; to Pierre Brisson, editor of Le Figaro, 30 May 1949 (all in Lemaigre Dubreuil Papers); and his letter on Catroux's memoirs, Dans la bataille de Méditerranée, published in Le Figaro, 30 September 1949.

63 Lemaigre Dubreuil to Albert Kammerer, 5 July 1946 (Lemaigre Dubreuil Papers).

64 Lemaigre Dubreuil to Giraud, 29 March 1943.

65 Auriol to Lemaigre Dubreuil, 11 July 1949 (Lemaigre Dubreuil Papers). 


\section{To die in Casablanca}

1 In Morocco Lesieur's chief competitors were two Marseille-based French firms, Cotelle et Foucher's Huileries et Savonneries du Maroc and Fournier-Ferrier's Huileries Marocaines.

2 Lemaigre Dubreuil, 'La France, le Maroc, l'Amérique,' L'Information politique, économique et financière, 22 November 1952.

3 Ibid.

4 Ibid. For Auriol's speech, see Annie Lacroix-Riz, Les Protectorats d'Afrique du Nord entre la France et Washington du débarquement à l'indépendance. Maroc et Tunisie, 1942-1956 (Paris, 1988). American policy at the UN was more pro-France than Lemaigre Dubreuil realized. See FRUS, 1952-1954, 11, part 1, pp. 142-4. Also see Martin Thomas, 'France Accused: French North Africa before the United Nations, 1952-1962,' Contemporary European History, 10, no. 1 (2000), pp. 91-121; Samya El Machat, Les États-Unis et le Maroc: le choix stratégique, 1945-1959 (Paris, 1996); Irwin M. Wall, The United States and the Making of Postwar France, 1945-1954 (New York, 1991); and Martin Thomas, 'Defending a Lost Cause? France and the United States Vision of Imperial Rule in French North Africa, 1945-1956,' Diplomatic History, 26, no. 2 (Spring 2002), pp. 215-47.

5 Lemaigre Dubreuil, 'La France, le Maroc, l'Amérique.' For France in Morocco, see William A. Hoisington, Jr., Lyautey and the French Conquest of Morocco (New York, 1995) and The Casablanca Connection: French Colonial Policy, 1936-1943 (Chapel Hill, 1984); Charles-André Julien, Le Maroc face aux impérialismes, 1415-1956 (Paris, 1978); and C. Richard Pennell, Morocco since 1830: A History (New York, 2000). For the deepening crisis over the protectorate, see Julien, Le Maroc face aux impérialismes, a detailed and at times autobiographical account, and Stéphane Bernard, The Franco-Moroccan Conflict, 1943-1956 (New Haven and London, 1968), as well as the memoirs of two residents general, General Alphonse Juin, Mémoires, 2 vols. (Paris, 1959-60) and General Augustin Guillaume, Homme de guerre (Paris, 1977).

6 Lemaigre Dubreuil, 'La France, le Maroc, l’Amérique.'

7 See the following notes among Lemaigre Dubreuil's papers which deal with these matters: 'Note sur quelques aspects juridiques d'une éventuelle transformation du régime actuel du Maroc,'n.d.; 'Note au sujet de la transformation éventuelle du Maroc en 'État Associé' intégré dans l'Union Française,' n.d.; and 'Note sur le problème marocain,' 29 March 1952.

8 Lemaigre Dubreuil to Bidault, 15 January 1953 (Lemaigre Dubreuil Papers) and Mauriac, 'La Vocation des chrétiens dans l'Union Française,' Le Figaro, 13 January 1953.

9 Pasha of Marrakech Thami al-Glawi to Monsieur Colin Faure, delegate of the Troisième Collège and member of the government council, 14 December 1952 (Lemaigre Dubreuil Papers).

10 Memorandum of the Delegation of the Elected Representatives of the French Population of Morocco to the French Government, 17 December 1952 (Lemaigre Dubreuil Papers).

11 Lemaigre Dubreuil, 'Le Maroc et la France,' L'Information politique, économique et financière, 22 January 1953 and also published in Le Petit Marocain/Le Progrès Marocain, 22 January 1953 and Paris (Casablanca, Alger, Tunis), 20 February 1953, the publication of the Présence Française in North Africa.

12 Lemaigre Dubreuil, 'Le Maroc et la France.'

13 Ibid.

14 Abderrazak Berrada to Lemaigre Dubreuil, 19 February 1953 and Lemaigre Dubreuil to Berrada, 27 February 1953 (both in Lemaigre Dubreuil Papers).

15 Draft memorandum for an Association Franco-Marocaine, 5 March 1953 (Lemaigre 


\section{The assassination of Jacques Lemaigre Dubreuil}

Dubreuil Papers). Lemaigre Dubreuil met with President Auriol (on 3 March) who urged him to discuss his planned Franco-Moroccan Association with Maurice Schumann, secretary of state for foreign affairs, who might be a useful 'stepping stone' in this matter. See Julien, Le Maroc face aux impérialismes, p. 272.

16 After independence Boucetta would serve as minister of justice; Bouabid as minister of state, of national economy, vice-president of the Council of Ministers, and ambassador to France; Abd el-Djellil as minister of agriculture, of education, and president of the Banque du Crédit Populaire; and Ben Kirane as member of the economic council, under secretary of state for commerce, industry, and mines, and director of the Office du Commerce Extérieur.

17 Dadi was vice-president of Amitiés Marocaines, another group that sought to bridge Franco-Moroccan differences. See Félix Nataf, L'Indépendance du Maroc. Témoignage d'action, 1950-1956 (Paris, 1975) and Hervé Bleuchot, Les Libéraux français au Maroc, 1947-1955 (Aix, 1973). Ben Bekkaï would be the first president of the Council of Ministers of independent Morocco and minister of the interior.

18 On the political division among French businessmen, see William A. Hoisington, Jr., 'Commerce and Conflict: French Businessmen in Morocco, 1952-55,' Journal of Contemporary History, 9, no. 2 (1974), pp. 49-67.

19 Lemaigre Dubreuil, 'Dialogue de sourds,' L'Information politique, économique et financière, 19 February 1953.

20 See Lemaigre Dubreuil to Pierre Fontaine, 6 May 1953 (Lemaigre Dubreuil Papers).

21 Lemaigre Dubreuil, 'Le Maroc et la France,' Le Monde, 20 June 1953.

22 Ibid.

23 Ibid.

24 Lemaigre Dubreuil, 'Avantages et périls d'une répudiation,' Le Monde, 30 October 1953.

25 Ibid.

26 Ibid.

27 The Comité France-Maghreb was presided over by François Mauriac, president, and Georges Izard, Charles-André Julien, and Louis Massignon, vice-presidents. Its founding declaration was signed by an array of luminaries, including Albert Camus, General Georges Catroux, Governor-General Robert Delavignette, Edmond Michelet, François Mitterand, and Léopold Senghor.

28 Lemaigre Dubreuil, 'Va-t-on laisser pourrir la situation?' Le Monde, 10 February 1954.

29 Lemaigre Dubreuil, 'La France à la croisée des chemins,' Le Monde, 12 March 1954. This was the second attempt on Moulay Ben Arafa's life. See the photographs and text in Julien's Le Maroc face aux impérialismes, pp. 280, 529.

30 Lemaigre Dubreuil, 'La France à la croisée des chemins.'

31 'Une lettre de M. Lemaigre Dubreuil à M. Joseph Laniel,' Le Monde, 14 April 1954.

32 Lemaigre Dubreuil, 'Le Maroc en péril,' Le Monde, 21 May 1954.

33 Ibid.

34 Ibid.

35 Lemaigre Dubreuil, 'Le Terrorisme au Maroc,' Le Monde, 3 June 1954. For the statistics on terrorism, see Annexe IV 'Terrorisme,' in Stéphane Bernard, Le Conflit francomarocain, 1943-1956, 3 vols. (Brussels, 1963), 3, following p. 352.

36 Lemaigre Dubreuil, 'Le Terrorisme au Maroc.'

37 See the account of the meetings (and the commentary 'Intrigues autour de M. Francis Lacoste' from France-Observateur, 10 June 1954) in Nataf, L'Indépendance $d u$ Maroc, pp. 89-96.

38 Lemaigre Dubreuil, 'Pour briser le cercle infernal,' Le Figaro, 16 June 1954.

39 Lemaigre Dubreuil to Zeghari, 7 July 1954 (Paul Aubry Papers). After independence Zeghari would serve as minister of state, vice-president of the Council of Ministers, minister of agriculture, agrarian reform, and economy, ambassador to France, and 
governor of the Bank of Morocco. Paul Aubry worked with Lemaigre Dubreuil from the days of the Taxpayers' Federation. In the 1950s he was a director of LesieurAfrique, Casablanca and helped gather documentation for Lemaigre Dubreuil's writings on Morocco.

40 Lemaigre Dubreuil, 'Faire vite,' Le Monde, 8 July 1954; Julien, Le Maroc face aux impérialismes, p. 363.

41 Lemaigre Dubreuil, 'Le Maroc,' Revue Politique et Parlementaire, 56, no. 7 (July 1954), pp. 9-15.

42 Alfred Grosser, La IVe République et sa politique extérieure (Paris, 1961), pp. 310-2.

43 Lemaigre Dubreuil, 'Grondements angoissants au Maroc,' Le Monde, 8-9 August 1954.

44 Lemaigre Dubreuil, 'Vérités sur le Maroc,' Le Monde, 27 August 1954. Also published in Le Journal du Maroc (Rabat), 11 September 1954.

45 Ibid.

46 Ibid.

47 Ibid.

48 Ibid.

49 Boyer de Latour to Lemaigre Dubreuil, 7 September 1954 (Lemaigre Dubreuil Papers). The title of Boyer de Latour's own reflections on policy in the Maghreb, Vérités sur l'Afrique du Nord (Paris, 1956), was intended to recall Lemaigre Dubreuil's article.

50 Lemaigre Dubreuil to Boyer de Latour, 10 September 1954 (Lemaigre Dubreuil Papers); Pacific Charter text, 8 September 1954, from The Avalon Project at the Yale University Law School. On Lemaigre Dubreuil, see Boyer de Latour, Vérités sur l'Afrique du Nord, pp. 125-6.

51 Lemaigre Dubreuil to Mendès France, 5 October 1954 (Lemaigre Dubreuil Papers).

52 Lemaigre Dubreuil to Mendès France, 5 October 1954 and enclosure 'Aide-mémoire sur le Maroc,' August 1954.

53 Lemaigre Dubreuil to Mendès France, 5 October 1954.

54 Ibid.

55 Ibid. By the end of December Lemaigre Dubreuil was also convinced that Mendès France was necessary at the head of the government in order to solve the Moroccan problem. See Lemaigre Dubreuil to Mendès France, 31 December 1954 and Mendès France to Lemaigre Dubreuil, 1 January 1955, in Pierre Mendès France, Oeuvres complètes, 6 vols. (Paris, 1984-90), 3, pp. 643-4.

56 Lemaigre Dubreuil to Mendès France, 5 October 1954.

57 Ibid. and 'Note annexe à la lettre adressée à Monsieur le Président Mendès France, le 5 Octobre 1954.' Juin was a hard-liner and fiercely anti-Mohammed Ben Youssef. He had served as Morocco's resident general from 1947 to 1951, was 'elevated to the dignity' of marshal of France in 1952, and elected to the Académie Française in 1953. Lemaigre Dubreuil knew him from the days after the Allied invasion of North Africa.

58 Lemaigre Dubreuil, 'Les 'bicots' et les 'ratons' du Maroc,' Le Monde, 15 October 1954.

59 Lemaigre Dubreuil, 'Éclaircie sur le Maroc,' Le Monde, 20 October 1954.

60 Ibid.

61 Lemaigre Dubreuil, 'Compte-rendu du dîner du 19 octobre 1954,' (Lemaigre Dubreuil Papers).

62 Ibid.

63 Lemaigre Dubreuil, 'Comment régler le problème marocain,' Combat, 4, 5, and 6 November 1954.

64 Ibid.

65 Ibid.

66 Ibid.

67 Ibid. 


\section{The assassination of Jacques Lemaigre Dubreuil}

68 'Synthèse des réponses des Français du Maroc au questionnaire du 22 novembre 1954' (Lemaigre Dubreuil Papers).

69 'Synthèse générale des réponses françaises et marocaine au questionnaire du 22 novembre 1954' (Lemaigre Dubreuil Papers).

70 Ibid.

71 Ibid.

72 Comité Directeur de l'Istiqlal, 'Réponse à Monsieur J. Lemaigre Dubreuil à la suite de son article du 6 novembre 1954,' 14 December 1954 and Parti Démocratique de l'Indépendance, 'Réponse au questionnaire du 22 novembre 1954,' both in Lemaigre Dubreuil Papers.

73 See Lemaigre Dubreuil, 'Note sur la question du trône,' 29 December 1954 and Lemaigre Dubreuil, 'La Crise marocaine,' n.d., both in Lemaigre Dubreuil Papers. Also see Lemaigre Dubreuil's short essay in the December 1954 issue of Évidences (pp. 19-21) which argues that a happy resolution of the sultanate would indicate a 'new orientation' for a Moroccan constitutional state.

74 Lemaigre Dubreuil, 'Rétrospective sur la crise marocaine,' Combat, 29 December 1954.

75 Ibid.

76 Lemaigre Dubreuil, 'Rétrospective sur la crise marocaine (II),' Combat, 30 December 1954.

77 Ibid.

78 Ibid.

79 Le Monde, 5 January 1955.

80 Lemaigre Dubreuil, 'L'Influence de l'évolution mondiale sur le problème marocain,' Le Monde, 1 February 1955.

81 Lemaigre Dubreuil, 'L'Influence de l'évolution mondiale sur le problème marocain.'

82 Lemaigre Dubreuil to Michel Deure, 17 February 1955 (Lemaigre Dubreuil Papers).

83 See La Correspondance de Presse, 25 April 1955. On Lemaigre Dubreuil and MarocPresse, see Jamaâ Baïda, La Presse marocaine d'expression française des origines à 1956 (Rabat, 1996), pp. 356-67. On the meeting with July, see Pierre July, Une République pour un roi (Paris, 1974), pp. 108-10. Baudouin de Moustier was married to Lemaigre Dubreuil's daughter. He was the brother of the Marquis Roland de Moustier, an Independent Republican deputy, who had led a parliamentary investigating committee to Morocco in January 1954. Its work was facilitated by Lemaigre Dubreuil who enabled committee members to talk with Moroccan leaders in hiding or in prison. On the committee, see Bernard, The Franco-Moroccan Conflict, pp. 198-203.

84 L'Écho de la Presse, 15 April 1955. By the spring of 1954 Maroc-Presse was losing more than one million francs in advertising every month.

85 Dimanche-Matin, 13 March 1955.

86 'Préamble à la situation marocaine en mars 1955,' 14 March 1955 (Lemaigre Dubreuil Papers). This unfortunate reference to Chicago in the 1930s was completely alien to what Lyautey had meant in 1914 when he admiringly called his modern skyscraper city in-the-making a 'Chicago on the Atlantic.'

87 'Note succincte à propos du terrorisme européen,' 14 March 1955 (Lemaigre Dubreuil Papers).

88 At the heart of Forestier's account was a description of the composition and operation of two Casablanca hit squads. See 'Note succincte à propos du terrorisme européen.' The 'Forestier affair' is open to dramatically different interpretations in part because not everything was known about him until some time after his death. See Le Monde, 9 May 1958 and the accounts in François Broche, L'Assassinat de Lemaigre-Dubreuil (Casablanca, le 11 juin 1955) (Paris, 1977), pp. 101-21 and Julien, Le Maroc face aux impérialismes, pp. 386-8.

89 'Note succincte à propos du terrorisme européen.' The government did commission an investigation into the police in Morocco by Directeur de la Surveillance du Territoire 
Roger Wybot. Wybot's report, ready at the end of March, recommended a total reorganization of police operations, but it was blocked by Resident General Lacoste and never implemented. At the same time in a puzzling twist Wybot accused Sartout of mounting counter-terrorist attacks that he and Forestier had organized by themselves in order to blame them on the French die-hards. See Julien, Le Maroc face aux impérialismes, pp. 396-400.

90 Maroc-Presse, 23 April 1955 and Le Monde, 25 April 1955.

91 Maroc-Presse, 23 April 1955 and Le Monde, 25 April 1955. From the start Lacoste opposed Lemaigre Dubreuil's Maroc-Presse initiative. See July, Une République pour un roi, pp. 110-1.

92 Lemaigre Dubreuil to Président Mendès France, 5 May 1955 (Lemaigre Dubreuil Papers).

93 On the conference, see Bleuchot, Les Libéraux français au Maroc, pp. 145-8. On Resident General Lacoste's ongoing concern that Maroc-Presse's editorials and news stories were causing 'a real upset' (un véritable désarroi) among those Moroccans who supported France as well as a growing 'unease'(un malaise général) among the Moroccan public in general, see Lacoste to Ministère des Affaires marocaines et tunisiennes, 7 June 1955, in Documents Diplomatiques Français, 1955, (1er janvier30 juin), (Paris, 1987), pp. 745-6.

94 Combat, 13 June 1955 and the New York Times, 13 June 1955. Also see July, Une République pour un roi, pp. 112-13. Arrests were very slow in coming, but some members of the police were involved in the assassination. See the summary and assessment after 3 years in Le Monde (9 May 1958) and the account by Broche, L'Assassinat du Lemaigre Dubreuil which focuses on the perpetrators.

95 Combat, 13 June 1955.

96 Le Figaro, 13 June 1955.

97 Times (London), 14 June 1955.

98 Le Monde, 14 June 1955. There are full biographical notices on Lemaigre Dubreuil in Maroc-Presse, 13 June 1955 and Le Monde, 14 June 1955.

99 Le Monde, 14 June 1955.

100 Ibid.

101 Ibid.

102 L'Écho d'Oran, 14 June 1955. On Lacoste's somewhat insensitive reaction to the assassination, see July, Une République pour un roi, pp. 104-5, 111-14. Also see Lacoste to July, 16 June 1955, in Documents Diplomatiques Français, 1955, (1er janvier-30 juin), pp. 779-83.

103 Oran Républicain, 14 and 15 June 1955 and Le Courrier du Maroc (Tangier), 14 June 1955. There may have been an attempt on Mendès France's life planned for the moment that he left the Casablanca cathedral. See Jean Lacouture, Pierre Mendès France (New York, 1984), pp. 370-1. On the Hotel El Mansour meetings, see Nataf, L'Indépendance du Maroc, p. 162.

104 Le Courrier du Maroc, La Dépêche de Constantine, L'Écho du Maroc, and Oran Républicain, all on 15 June 1955. Also see July, Une République pour un roi, pp. 11516. The day after the funeral services in Casablanca Lemaigre Dubreuil's body was flown to Paris for burial at his property at Larchant, near Fontainebleau. See Le Petit Marocain, 16 June 1955.

105 Bulletin de Paris, 17 June 1955.

106 Juin's note read in part: 'Witness to his courageous efforts since Algiers, I had a very high opinion of him. I knew that with his customary commitment (ardeur coutumière) and great generosity of heart he would try to find a solution to the current Moroccan trouble. And even if our views on certain points of detail were somewhat different (quelque peu différentes), I approved without exception (sans réserve) that he tried by every available means to bring Frenchmen and Moroccan nationalists together and to re-establish a climate of harmony. Alas! because of political stalemate (immobilisme), 


\section{The assassination of Jacques Lemaigre Dubreuil}

Casablanca today is nothing more than a hotbed of anarchy (foyer d'anarchie) where government authority is powerless to calm the passions and to prevent such abominable crimes. And, as always, it is the best who fall and our country has just lost a great Frenchman.' See Maroc-Presse, 17 June 1955. Juin resigned from the Comité de Coordination pour les Affaires d'Afrique du Nord on 2 July. See Maroc-Presse, 2 and 3 July 1955.

107 L'Express, 18 June 1955.

108 Ibid. Mendès France's essay was also published in Maroc-Presse, 17 June 1955 and excerpted in Le Monde, 18 June 1955; it is included in Mendès France, Oeuvres complètes, 4, pp. 66-8.

109 L'Express, 18 June 1955. Mauriac also maintained that Lemaigre Dubreuil's death underscored the 'impotence' (impuissance) of the state and in consequence the need to oust the conservative right-wing majority in the 1956 legislative elections in favor of a new center-left Popular Front coalition.

110 Maroc-Presse, 24 July 1955.

111 See the account in Julien, Le Maroc face aux impérialismes, pp. 433-6.

112 On Grandval's tenure, see Gilbert Grandval, Ma Mission au Maroc (Paris, 1956) and July, Une République pour un roi, pp. 123-82.

113 All this, of course, with none of the guarantees for France or Frenchmen that Lemaigre Dubreuil had hoped would be part of a Franco-Moroccan settlement.

114 Boyer de Latour, Vérités sur l'Afrique du Nord, p. 125.

115 Maroc-Presse, 6 November 1955. Maroc-Presse ceased publication on 30 April 1956.

116 Le Petit Matin (Tunis), 12 June 1959.

\section{Conclusion}

1 Lemaigre Dubreuil, 'Le Maroc et la France,' Le Monde, 20 June 1953. 


\section{Bibliography}

\section{Manuscript sources}

\section{Private Papers}

Charles Noguès Papers, Paris.

Jacques Lemaigre Dubreuil Papers, Paris.

Mark W. Clark Papers, The Citadel, Charleston, SC.

Paul Aubry Papers, Paris.

\section{Public Archives}

Archives de la Préfecture de Police, Paris B/A 351p 79501-953-1 (Fédération Nationale des Contribuables).

\section{Privately printed materials}

Fédération Nationale des Contribuables, Les Contribuables. Imprimerie Crété, Paris 1935.

Fédération Nationale des Contribuables, La Gestion de la ville de Paris: le Project du budget contribuable. Paris 1938.

Fédération Nationale des Contribuables, La Situation financière des collectivités publiques françaises en 1939. Paris 1939.

Fédération Nationale des Contribuables, Fédération départementale des contribuables du Maine-et-Loire, Contribuables, groupez-vous, défendez-vous: Examen des budgets d' Angers. Nantes 1937-1938.

Fédération Nationale des Contribuables, Groupement de défense des contribuables de Nantes, A propos du budget de la ville de Nantes. Rennes 1939.

Lemaigre Dubreuil, J., La Rentrée en guerre de la France africaine aux côtés des Alliés, le 8 novembre 1942. Imprimerie Paul Dupont, Paris 1944.

Société Georges Lesieur et ses Fils, De Dunkerque à Dakar, 1940-1950. Imprimerie de Draeger, Paris 1950.

Société Georges Lesieur et ses Fils, Historique., n.p., n.d.

Société Georges Lesieur et ses Fils, L'Usine de Coudekerque-Branche et l'occupation allemande. n.p., 1944.

Wenger, L., 55 ans de Pétrole, 1904-1959: Souvenirs de Léon Wenger. Imprimerie Fabre, Paris 1968.

Wenger, L., La Participation française dans la recherche et la production du pétrole. Imprimerie Presses Continentales, Paris 1943. 
170 The assassination of Jacques Lemaigre Dubreuil

\section{Government documents and official publications}

\section{France}

Armée, État-Major, Les Documents secrets de l'État-major général français, Deutsches Weissbuch des Auswärtigen Amtes, no. 6. Imprimé au Deutscher Verlag, Berlin 1941.

Assemblée Nationale, Charles Serre, Rapport fait au nom de la commission chargée d'enquêter sur les événements survenus en France de 1933 à 1945, 9 vols. Presses Universitaires de France, Paris 1952.

Conseil Municipal de Paris, Procès-verbaux et déliberations des séances de l'Assemblée du Conseil Municipal de Paris. Imprimerie Municipale, Hôtel de Ville, Paris 1937-39.

Chambre des Députés, Journal Officiel de la République Française, Débats parlementaires. Imprimerie Nationale, Paris 1920-56.

Chambre des Députés, Marc Rucart, Rapport général fait au nom de la commission d'enquête chargée de rechercher les causes et les origines des événements du 6 février 1934 et jours suivants, ainsi que toutes les responsabilités encourues, 4 vols. Imprimerie de la Chambre des Députés, Paris 1934.

La Délégation française auprès de la commission allemande d'armistice, Recueil de documents publié par le gouvernement français, 5 vols. A. Costes, Paris 1947-59.

Ministère des Affaires Étrangères, Commission de publication des documents diplomatiques français, Documents Diplomatiques Français, 1954 (21 juillet-31 décembre) and 1955 (ler janvier-30 juin). Imprimerie Nationale, Paris 1987.

\section{Germany}

Auswärtiges Amt, Documents on German Foreign Policy, 1918-1945, Series D (1937-45), 13 vols. U.S. Government Printing Office, Washington 1949-83.

\section{League of Nations}

International Trade Statistics. Annually, Geneva 1934-38.

Statistical Yearbook of the League of Nations, 1940/1941. Geneva 1941.

World Economic Survey, 1938/1939. Geneva, 1939; World Economic Survey,1939/1941. Geneva, 1941.

\section{United States}

U.S. Department of State, Foreign Relations of the United States: Diplomatic Papers. U.S. Government Printing Office, Washington 1940-89.

U.S. Department of State, Foreign Relations of the United States: The Conferences at Washington, 1941-1942 and Casablanca, 1943. U.S. Government Printing Office, Washington 1968.

\section{Books}

Aldrich, R., Greater France: A History of French Overseas Expansion. Macmillan, London 1996.

Arbellot, S., La Presse française sous la francisque. L’Écho de la Presse et de la Publicité, Paris 1952. 
Aron, R., Histoire de l'Épuration, 3 vols. Fayard, Paris 1967-75.

Atkinson, R., An Army at Dawn: The War in North Africa, 1942-1943. Henry Holt and Company, New York 2002.

Auriol, V., Journal du Septennat, 1947-1954, 7 vols. Armand Colin, Paris 1970-75.

Baïda, J., La Presse marocaine d'expression française des origines à 1956. Publications de la Faculté des Lettres et des Sciences Humaines de l'Université Mohammed V, Rabat 1996.

Bankwitz, P. C. F., Maxime Weygand and Civil-Military Relations in Modern France. Harvard University Press, Cambridge 1967.

Barrat, R., Justice pour le Maroc. Éditions du Seuil, Paris 1953.

Basch, A., The Danube Basin and the German Economic Sphere. Columbia University Press, New York 1943.

Beaufre, A., Mémoires, 1920-1940-1945. Presses de la Cité, Paris 1965.

__, La Revanche de 1945. Plon, Paris 1966.

Berger, S., Peasants Against Politics: Rural Organization in Brittany, 1911-1967. Harvard University Press, Cambridge 1972.

Bernard, S., Le Conflit franco-marocain, 1943-1956, 3 vols. Editions de 1'Institut de Sociologie de l'Université Libre de Bruxelles, Brussels 1963: The Franco-Moroccan Conflict, 1943-1956. Yale University Press, New Haven and London 1968 in English translation.

Berstein, S., Le 6 février 1934. Éditions Gallimard/Julliard, Paris 1975.

Berteil, L., L'Armée de Weygand: La Chance de la France, 1940-1942. Albatros, Paris 1975.

Béthouart, A. É., Cinq années d'espérance. Mémoires de guerre, 1939-1945. Plon, Paris 1968.

Bleuchot, H., Les Libéraux français au Maroc, 1947-1955. Éditions de l'Université de Provence, Aix 1973.

Bonnet, G., Défense de la paix, 2 vols. Éditions du Cheval Ailé, Geneva 1946-48.

Boyer de Latour du Moulin, P., Vérités sur l'Afrique du Nord. Plon, Paris 1956.

Broche, F., L'Assassinat de Lemaigre-Dubreuil (Casablanca, le 11 juin 1955). Balland, Paris 1977.

Catroux, G., Dans la bataille de Méditerranée, Égypte-Levant-Afrique du Nord, 19401944. René Julliard, Paris 1949.

Cavalier, A., La Révolte des contribuables. Éditions Bossard, Paris 1932.

Cerych, L., Européens et Marocains, 1930-1956; Sociologie d'une décolonisation. De Tempel, Bruges 1964.

Chamine [Géneviève Dunais], La Conjuration d'Alger. Albin Michel, Paris 1946.

— La Querelle des généraux Albin Michel, Paris 1952.

Clark, M. W., Calculated Risk. Harper, New York 1950.

Clayton, A., France, Soldiers and Africa. Brassey's Defence Publishers, London 1988.

- The Wars of French Decolonization. Longman, London and New York 1994.

Colton, J., Léon Blum: Humanist in Politics. Alfred A. Knopf, New York 1966.

Coutau-Bégarie, H. and Huan, C., Darlan. Fayard, Paris 1989.

Crusoé [Jacques Lemaigre Dubreuil], Vicissitudes d'une victoire. Les Éditions de l'Âme française, Paris 1946.

Darlan, F., Lettres et notes de l'amiral Darlan [recueillies par] Hervé Coutau-Bégarie et Claude Huan. Economica, Paris 1992.

Detton, H., L'Administration régionale et locale en France. Presses Universitaires de France, Paris 1960. 


\section{The assassination of Jacques Lemaigre Dubreuil}

Dorgères, H., Haut les fourches. Les Oeuvres françaises, Paris 1935.

—

Dougherty, J. J., The Politics of Wartime Aid: American Economic Assistance to France and Northwest Africa, 1940-1946. Greenwood Press, Westport 1978.

Dulles, E. L., The French Franc, 1914-1928. Macmillan, New York 1929.

Eisenhower, D. D., The Papers of Dwight David Eisenhower: The War Years, 5 vols. in Chandler, A. D., ed., Johns Hopkins University Press, Baltimore 1970.

El Machat, S., Les États-Unis et le Maroc: le choix stratégique, 1945-1959. L'Harmattan, Paris 1996.

Fernand-Laurent, J. C., Un peuple ressuscite. Brentano's, New York 1943.

Forter, N. L., and Rostovsky, D. B., The Roumanian Handbook. Simpkin, Marshall, Ltd., London 1931.

Funk, A. L., Charles de Gaulle: The Crucial Years, 1943-1944. University of Oklahoma Press, Norman 1959.

- The Politics of TORCH: The Allied Landings and the Algiers Putsch, 1942. The University Press of Kansas, Lawrence 1974.

Gabriel-Robinet, L., Dorgères et le front paysan. Plon, Paris 1937.

Gafencu, G., Prelude to the Russian Campaign, from the Moscow Pact (August 21st, 1939) to the Opening of Hostilities in Russia (June 22nd 1941). F. Muller Ltd., London 1945.

Gates, E. M., End of the Affair: The Collapse of the Anglo-French Alliance, 1939-40. University of California Press, Berkeley 1981.

de Gaulle, C., Mémoires de guerre, 3 vols. Plon, Paris 1954-59.

Germain-Martin, H., Le Problème financier, 1930-1936. Éditions Domat-Montchrestin, Paris 1936.

Giraud, H. H., Un seul but, la victoire. Alger, 1942-1944. René Julliard, Paris 1949.

—, Mes Évasions. Librairie Arthème Fayard, Paris 1951.

Gooch, R. K., Regionalism in France. The Century Company, New York 1931.

Grandval, G., Ma mission au Maroc. Plon, Paris 1956.

Grosser, A., La IVe République et sa politique extérieure. Armand Colin, Paris 1961.

—, Affaires extérieures: la politique de la France, 1944-84. Flammarion, Paris 1984.

Guillaume, A., Homme de guerre. France-Empire, Paris 1977.

Gunsburg, J. A., Divided and Conquered: The French High Command and the Defeat of the West, 1940. Greenwood Press, Westport 1979.

Haig, R. M., The Public Finances of Post-War France. Columbia University Press, New York 1929.

Hall, L. J., The United States and Morocco, 1776-1956. Scarecrow Press, Metuchen 1971.

Hillgruber, A., Hitler, König Carol und Marschall Antonescu, die deutsch-rümanischen Beziehungen, 1938-1944. F. Steiner, Wiesbaden 1954.

Hoisington, W. A., Jr., The Casablanca Connection: French Colonial Policy, 1936-1943. The University of North Carolina Press, Chapel Hill 1984.

—, Lyautey and the French Conquest of Morocco. St. Martin's Press, New York 1995.

Howe, G. F., Northwest Africa: Seizing the Initiative in the West, in The United States Army in World War II: Mediterranean Theater of Operations. U.S. Government Printing Office, Washington 1957.

Hurstfield, J. G., America and the French Nation, 1939-1945. The University of North Carolina Press, Chapel Hill 1986.

Jackson, J., The Politics of Depression in France, 1932-1936. Cambridge University Press, New York 1985. 
- France: The Dark Years, 1940-1944. Oxford University Press, Oxford 2001.

Juin, A. P., Le Maghreb en feu. Plon, Paris 1957.

- Mémoires, 2 vols. A. Fayard, Paris 1959-60.

Julien, C. A., Le Maroc face aux impérialismes, 1415-1956. Éditions Jeune-Afrique, Paris 1978.

July, P., Une République pour un roi. Fayard, Paris 1974.

Junot, M., Opération 'Torch' 8 novembre 1942; Les Américains débarquent en Algérie; Le rôle décisif de cinq jeunes Français dans le tournant de la guerre. Éditions de Fallois, Paris 2001.

Kammerer, A., Du Débarquement africain au meurtre de Darlan. Flammarion, Paris 1949.

Kaspi, A., La Mission de Jean Monnet à Alger, mars-octobre 1943. Éditions Richelieu, Publications de la Sorbonne, Paris 1971.

- Franklin D. Roosevelt. Librairie Arthème Fayard, Paris 1988.

Kemp, T., The French Economy, 1913-1939, The History of a Decline. St. Martin's Press, New York 1972.

Krautkrämer, E., Frankreichs Kriegswende 1942: die Rückwirkungen der alliierten Landung in Nordafrika: Darlan, De Gaulle, Giraud, und die royalistsche Utopie. Bern, Frankfurt am Main, New York and Paris: Peter Lang, 1989; in revised and expanded French translation, Vichy-Alger, 1940-1942: le chemin de la France au tournant de la guerre. Economica, Paris 1992.

Kuisel, R. F., Ernest Mercier, French Technocrat. University of California Press, Berkeley and Los Angeles 1967.

Lacouture, J., Cinq hommes et la France. Seuil, Paris 1961.

__, Pierre Mendès France. Seuil, Paris 1981; Holmes \& Meier, New York 1984 in English translation.

$\longrightarrow$, De Gaulle, 3 vols. Éditions du Seuil, Paris 1984-86; 2 vols. Norton, New York 199092 in English translation.

Lacroix-Riz, A., Les Protectorats d'Afrique du Nord entre la France et Washington $d u$ débarquement à l'indépendance. Maroc et Tunisie, 1942-1956. L'Harmattan, Paris 1988.

Langer, W. L., Our Vichy Gamble. Alfred A. Knopf, New York 1947.

Larmour, P. J., The French Radical Party in the 1930's. Stanford University Press, Stanford 1964.

Leahy, W. D., I was there. McGraw-Hill, New York 1950.

Lemaigre Dubreuil, J., Les Relations franco-américaines et la politique des généraux, Alger, 1940-1943. Publications Élysées, Paris 1949.

Levisse-Touzé, C., L'Afrique du Nord dans la guerre, 1939-1945. Albin Michel, Paris 1998.

Lucas, H., Die Deutsch-Rumänischen Wirtschaftsbeziehungen in neuerer Zeit. K. Triltsch, Würzburg 1940.

Marder, A. J., Operation 'Menace:' The Dakar Expedition and the Dudley North Affair. Oxford University Press, London and New York 1976.

Mast, C., Histoire d'une rébellion. Alger, 8 novembre 1942. Le Cercle du Nouveau Livre d'Histoire, Paris 1969.

Medlicott, W. N., The Economic Blockade, 2 vols. H.M. Stationery Office, London 1952, 1959.

Melton, G. E., Darlan: Admiral and Statesman of France, 1881-1942. Praeger, Westport 1998.

Mendès France, P., Oeuvres complètes, 6 vols. Gallimard, Paris 1984-90.

Monnet, J., Mémoires. Fayard, Paris 1976. 
Montagne, R., Révolution au Maroc. France-Empire, Paris 1954.

Mouré, K., Managing the Franc Poincaré: Economic Understanding and Political Constraint in French Monetary Policy, 1928-1936. Cambridge University Press, New York 1991.

- The Gold Standard Illusion: France, the Bank of France, and the International Gold Standard, 1914-1939, Oxford University Press, Oxford 2002.

Murphy, R. D., Diplomat Among Warriors. Doubleday, Garden City 1964.

Nataf, F., L'Indépendance du Maroc. Témoignage d'action, 1950-1956. Plon, Paris 1975.

Neubacher, H., Sonderauftrag Südost, 1940-1945, Bericht eines fliegenden Diplomaten. Musterschmit-Verlag, Göttingen 1956.

Nicolle, P., Cinquante mois d'armistice, 2 vols. André Bonne, Paris 1947.

Ordioni, P., Le Secret de Darlan, 1940-1942: le vrai rival de De Gaulle. Albatros, Paris 1976.

Orlow, D., The Nazis in the Balkans: A Case Study of Totalitarian Politics. University of Pittsburgh Press, Pittsburgh 1968.

Paillat, C., L'Échiquier d'Alger, 2 vols. Robert Laffont, Paris 1966-67.

Paxton, R. O., Vichy France: Old Guard and New Order, 1940-1944. Alfred A. Knopf, New York 1972.

- French Peasant Fascism: Henry Dorgères's Greenshirts and the Crises of French Agriculture, 1929-1939. Oxford University Press, New York 1997.

Pennell, C. R., Morocco since 1830: A History. New York University Press, New York 2000.

Piétri, F., Mes Années d'Espagne, 1940-1948. Plon, Paris 1954.

Rivet, D., Le Maroc de Lyautey à Mohammed V: le double visage du protectorat. Éditions Denoël, Paris 1999.

— , ed., Le Comité France-Maghreb: réseaux intellectuels et d'influence face à la crise marocaine (1952-1955). Les Cahiers de l'Institut d'Histoire du Temps Présent, Paris no. 38, December 1997.

Roberts, H. L., Rumania, Political Problems of an Agrarian State. Yale University Press, New Haven 1951.

Rodière, R., Législation de l'Afrique du nord en guerre, 8 novembre 1942-8 novembre 1943 (droit privé et droit criminel), Algiers, La Maison des Livres, n.d. 1940-49.

Rogers, J. H., The Process of Inflation in France, 1914-1927. Columbia University Press, New York 1929.

Rossi, M., Roosevelt and the French. Praeger, Westport and London 1993.

Rozelet, A. M., Passeurs d'expérance: Français libéraux dans le Maroc en crise, 1945 1955. Afrique Orient, Casablanca 1998.

Sauvy, A., Histoire économique de la France entre les deux guerres, 3 vols. Fayard, Paris 1965-72.

Schuker, S. A., The End of French Predominance in Europe: The Financial Crisis of 1924 and the Adoption of the Dawes Plan. The University of North Carolina Press, Chapel Hill 1976.

Shoup, C. S., The Sales Tax in France. Columbia University Press, New York 1930.

Spillmann, G., Du Protectorat à l'indépendance, Maroc, 1912-1955. Plon, Paris 1967.

—, Souvenirs d'un colonialiste. Presses de la Cité, Paris 1968.

Sullivan, C. K., The Tax on Value Added. Columbia University Press, New York and London 1965.

Thomas, M., The French Empire at War, 1940-45. Manchester University Press, Manchester 1998.

Thomas, R. T., Britain and Vichy: The Dilemma of Anglo-French Relations, 1940-42. 
St. Martin's Press, New York 1979.

Van Hecke, A. S., Les Chantiers de la jeunesse au secours de la France (souvenirs d'un soldat). Nouvelles Éditions Latines, Paris 1970.

Wall, I. M., The United States and the Making of Postwar France, 1945-1954. Cambridge University Press, New York 1991.

Warner, G., Pierre Laval and the Eclipse of France. Macmillan, New York 1968.

Weber, E., Action Française: Royalism and Reaction in Twentieth-Century France. Stanford University Press, Stanford 1967.

Weygand, M., Mémoires, 3 vols. Flammarion, Paris 1950-57.

Wolfe, M., The French Franc Between the Wars, 1919-1939. Columbia University Press, New York 1951.

Wright, G., Rural Revolution in France: The Peasantry in the Twentieth Century. Stanford University Press, Stanford 1964.

Zeldin, T., France, 1848-1945, 2 vols. Oxford University Press, Oxford 1973-77.

\section{Articles and chapters in books, theses and dissertations}

Bankwitz, P. C.F., 'Paris on the sixth of February, 1934: Riot, insurrection, or revolution?' in Gooch, B. D. ed., Interpreting European History. Dorsey Press, Homewood 1967, pp. 337-68.

Beloff, M., 'The Sixth of February,' in Joll, J. ed., The Decline of the Third Republic. St. Antony's Papers, no. 5. Chatto \& Windus, London 1959, pp. 9-35.

Bopp, K. R., 1941. 'The Government and the Bank of France,' Public Policy, 2:3-35.

Boris, G., 1936. 'Reforming the Bank of France,' Foreign Affairs, 15:155-64.

Broszat, M., 1968. 'Deutschland-Üngarn-Rumänien, Entwicklung und Grundfaktoren nationalsozialistischen Hegemonial-und Bündnispolitik 1938-1941,' Historische Zeitschrift, 206:45-96.

Clayton, A., 1993. 'Emergency in Morocco, 1950-56,' Journal of Imperial and Commonwealth History, 21(3):129-47.

Fisher, A. G. B., 'World Economic Affairs,' in Toynbee A. J., ed., Survey of International Affairs, 1938. 3 vols. Oxford University Press, London 1941, 1951, 1953.

Fox, B. C., 'German Relations with Romania, 1933-1944,' Ph.D. Dissertation, Western Reserve University, 1964.

Funk, A. L., 1953. 'A Document Relating to the Second World War: The Clark-Darlan Agreement, November 22, 1942,' Journal of Modern History, 25(1):61-5.

— 1954. 'The "Anfa Memorandum:" An Incident of the Casablanca Conference,' Journal of Modern History, 26(3):246-54.

- 1971. 'Eisenhower, Giraud, and the Command of 'TORCH', Military Affairs, 25(3):103-08.

_ 1973 . 'Negotiating the "Deal with Darlan," Journal of Contemporary History, 8(2):81-117.

Hoisington, W. A., Jr., 1971. 'The Struggle for Economic Influence in Southeastern Europe: The French Failure in Romania, 1940,' Journal of Modern History, 43(3):468-82.

— 1974. 'Commerce and Conflict: French Businessmen in Morocco, 1952-55,' Journal of Contemporary History, 9(2):49-67.

— 1976. 'Toward the Sixth of February: Taxpayer Protest in France, 1928-1934,' Historical Reflections/Réflexions historiques, 3(1):49-67.

Jèze, G., 1933. 'Le refus concerté de payer l'impôt,' Revue de science et de législation financières, 31:257-60. 


\section{The assassination of Jacques Lemaigre Dubreuil}

Katz, J. G., 2001. 'The 1907 Mauchamp Affair and the French Civilising Mission in Morocco,' Journal of North African Studies, 6(1):143-66.

Krautkrämer, El., 1982. 'General Giraud und Admiral Darlan in der vorgeschichte der alliierten Landung in Nordafrika,' Viertelsjahrshefte für Zeitgeschichte, 30(3):206-55.

Kupferman, A., 'François Coty, journaliste et homme politique,' Paris: Faculté des Lettres et des Sciences Humaines de Paris, Doctorat de Troisième Cycle, 1965.

Laufenburger, H., 1953. 'Technical and Political Aspects of Reform of Taxation in France,' National Tax Journal, 6:273-85.

Lemaigre Dubreuil, J., 1949. 'Giraud et de Gaulle à Alger,' Revue de Paris, July:91-108.

—_, 1954. 'Le Maroc,' Revue Politique et Parlementaire, 56(7):9-15.

Peyret, H., 'Les Pétroles,' in Boudet, J. ed., Le Monde des affaires en France de 1830 à nos jours. Société d'édition de dictionnaires et encyclopdies, Paris 1952.

Rémond, R., 1959. 'Explications du 6 février,' Politique, 7,8:218-30.

Royer, J. M., 'De Dorgères à Poujade,' in Fauvet, J. and Mendras, H. eds, Les Paysans et la politique dans la France contemporaine, A. Colin, Paris 1958, pp. 149-206.

Sangmuah, E. N., 1992. 'Sultan Mohammed Ben Youssef's American Strategy and the Diplomacy of North African Liberation, 1943-61,' Journal of Contemporary History, 27(1): pp.129-48.

Sauvy, A., 1969. 'The Economic Crisis of the 1930's in France,' Journal of Contemporary History, 4(4):21-35.

Thomas, M., 1996. 'To Arm an Ally: French Arms Sales to Romania, 1926-1940,' The Journal of Strategic Studies, 19(2):231-59.

M., 1996. 'The Discarded Leader: General Henri Giraud and the Foundation of the French Committee of National Liberation,' French History, 10(1):86-111.

- 2000. 'France Accused: French North Africa before the United Nations, 1952-1962,' Contemporary European History, 10(1):91-121.

—, M., 2002. 'Defending a Lost Cause? France and the United States Vision of Imperial Rule in French North Africa, 1945-1956,' Diplomatic History, 26(2):215-47.

Treue, W., 1953. 'Das Dritte Reich und die Westmächte auf dem Balkan, zur Struktur der Aussenhandelspolitik Deutschlands, Grossbritanniens und Frankreichs 1933-1939,' Vierteljahrshefte für Zeitgeschichte, 1:45-64.

Walker, D. A., 1987. 'OSS and Operation TORCH,' Journal of Contemporary History, 22(4):667-79.

Warner, G., 1958. 'The Stavisky Affair and the Riots of February 6th 1934,' History Today, June:377-85.

\section{Newspapers and periodicals}

L'Action contribuable, 1935-39.

La C.G.C. (Confédération Générale des Contribuables), 1928-37.

La Tribune des contribuables de Franche-Comté, 1934-36.

Le Contribuable de Saône-et-Loire, 1931-33.

Le Cri du contribuable, 1933-36.

Le Jour-Écho de Paris, 1938-42.

Le Réveil du contribuable, 1930-35.

Maroc-Presse, 1952-56. 


\section{Index}

6 February $19341,12-15,36,138,144 \mathrm{n} 90$

Abd el-Djellil, Hadj Omar 105

Abetz, Otto 96

L'Action contribuable 27, 29, 34, 41-2, 44, $128,145 \mathrm{n} 95$

Action Française 7, 10, 12, 22

Action française (newspaper) 17

Aix-les-Bains, Franco-Moroccan

Conference at (22-27 August 1955) 137

L'Alerte 54

Algeciras, Act of (7 April 1906) 103

Algeria 55, 58-9, 61, 63, 68, 71-2, 74, $77-8,80,83,86,93,97,121,126$

Algiers: in World War II 54, 60-5, 67-72, 74-6, 83, 86-7, 89-99, 112, 139, 167n106; and Allied landings (1942) 76-81, 158n55, 158n66; and Société Georges Lesieur et Ses Fils 57-8, 64, 99

Allied Combined Chiefs of Staff, 70, 76

Alsace-Lorraine 57

L'Ami du people 1

Amitiés Marocaines 112, 164n17

Anfa Memorandum see Casablanca Conference

Anglo-Persian Oil Company (later AngloIranian Oil Company) 50, 153n30

Anthouard de Wasservas, Baron Albert d' 2-7, 9, 13-14

Arab League 107, 114

Arabs 115, 123, 126; in Morocco 111, 115

Arafa, Sultan Sidi Mohammed Ben 107, $109,114,116-21,125,135$

Association for the Defense of the Middle Classes, 2

Association Franco-Marocaine 105, 163n 15

Atherton, Ray 86-7, 89

Aubry, Paul 164n39
Auguet, Gaston 38

Auriol, Vincent 27, 41, 98, 101, 163n15

L'Aurore 133

Axis 51, 62, 64, 66, 69, 71-2, 78, 80, $88-9,157 \mathrm{n} 41$; see also Germany, Italy

Bailby, Léon 53-4

Balkans 45-8, 51-3

Bank of France 64, 147n140, 148n146; and Lemaigre Dubreuil 27-31, 33, 44-5, 53, 62, 84, 93, 98, 138; and Taxpayers' Federation 24, 26, 29

Banque du Pays du Nord 15

Bardou, Dr. Georges 14

Barthélemy, Joseph 16, 62

Bastid, Paul 97

Baudouin, Paul 52

Baugnies, Georges 33, 148n 147

Beaufre, General André 53, 63

Beirut 51, 53

Bekkaï, M'Barek Ben 105, 112, 137

Berbers: in Morocco 111, 115, 136-7

Bérenger, Henry 13

Bergeret, General Jean 77, 93, 95

Berlin 55, 61

Berrada, Abderrazak 104

Béthouart, General Antoine-Émile 69, 78, $85,91,134$

Bidault, Georges 102, 124

Bizerte 64

Blida 76-7

Blum Léon 12, 14, 24, 26-7, 30, 32, 41, $98,143 \mathrm{n} 47$

Boissière, Gabriel 27

Boisson, Governor General Pierre 57, 83, 96

Bonnet, Georges 30, 32, 44

Bouabid, Abderrahim, 105

Boucetta, Muhammed, 105 


\section{The assassination of Jacques Lemaigre Dubreuil}

Boujad 136

Boulard, André 38

Bouton, André 14, 17, 145n98

Boyer de Latour du Moulin, General Pierre 117,137

Brunhes, Jean 21

Bucharest 45-7, 50-3

Bulgaria 49

Caillaux, Joseph 7

Cairo 94, 109, 111

Camelots du Roi 7-8, 10

Cameroons 123

Le Canard enchainé 29

Casablanca: and Société Georges Lesieur et Ses Fils 57-8, 97, 99-100, 164n39; in World War II 54, 69, 71, 78, 96; in the 1950s 99, 102-3, 105, 107, 109, 125-6, 128-37, 139, 166n88, 167n103, 167n104, 167n106; see also Casablanca

Conference, Morocco

Casablanca Conference (17-27 January 1943) 86, 90-1, 93, 100; Anfa

Memorandum

91-3, 95, 161 n 35

Castellaz, Louis 38-9

Catroux, General Georges 87, 94, 162n48, $162 \mathrm{n} 62,164 \mathrm{n} 27$

Cavalier, Auguste 1

Celier, Charles 133

Chamber of Deputies (Palais Bourbon) 1, 6-7, 9-10, 12, 15-16, 22, 24, 32, 44, 54, $96,102,109,124,127,144$ n90, $147 \mathrm{n} 145,148 \mathrm{n} 146$

Chapelle, Fernand Bonnier de la 160n17

Châtel, Yves 68, 80, 83, 93

Chautemps, Camille 10, 30, 32, 56

Cherchell, Franco-American meeting at (21-22 October 1942) 74

Chiappe, Jean 144 n90

Chicago 100, 129, 133, 166n86

Chrétien, Colonel Jean 72-3, 158n65

Churchill, Winston S. 86, 88, 90, 92-3

Clark, General Mark W. 74, 79-81, 83, 85-6

Clark-Darlan Agreement (22 November 1942) 81,85

Clermont-Ferrand 54-5

Clostermann, Pierre 132

Cold War East-West conflict 100, 107, 113,.117, 127

Cole, Felix 71

Collaboration: Franco-German 50, 60, 63-4, 68, 75; Franco-Moroccan 102, 107, 111
Colonialism 21, 57-8, 62, 73, 100-2, 106, $113,117,122$, 127; see also French empire

Combat 121, 123, 125, 132

Comité de Coodination pour les Affaires d'Afrique du Nord (North African Coordination Committee) 135, 167n106

Comité de Guerre see French Imperial Federation

Comité France-Maghreb 109, 164n27

Comité National d'Entente Économique $10-11$

Comité d'Organisation de l'Huilerie 57

Committee of Five (or the Five) 64, 66-73, 76-9, 81, 83, 87, 97-9, 157n37

Communist Party (PCF) 8-9, 22, 24, 38-9, $62,97,116,143 n 47$

Compagnie Africaine de Banque 105

Compagnie Fermière des Eaux d'OulmèsÉtat 105, 132

Compagnie Occidentale des Produits du Pétrole $153 \mathrm{n} 30$

Compagnie Sucrière Marocaine 105

Concordia 49-50, 152n28

Confédération Générale des Contribuables (CGC) 1, 141

Confédération Générale des Fonctionnaires 2

Confédération Générale du Travail (CGT) 8-9, 27

Conférence Nationale pour la Solution du Problème Franco-Marocain (7-8 May 1955) 131

Conscience Française 132

Conseil Supérieur des Oulémas 119

Les Contribuables 18-19, 23

Corsica 107

Coty, François 1, 4, 16, 143n70

Couderkerque-Branche 56-9

Count of Paris, Henri 131

Croix de Feu, 1, 6

Cruse, Lorrain 105

Czechoslovakia 45-6

Dadi, M'hamed 105

Dakar 15, 54-5, 57-9, 61, 63-4, 99; Anglo-Gaullist attack on (23-5 September 1940) 55, 61

Daladier, Édouard 10-12, 39, 41, 44

Dar Balek, 99

Darlan, Admiral François: and Vichy 71-3; and Allied landings in North Africa 79-81; as High Commissioner in French Africa 82-5, 159n11; assassinated 86-7, 
160n17; see also Clark-Darlan

Agreement, French Imperial Federation

Dar Mahieddine 64, 78

Défendre 1

De Gaulle, General Charles 55, 61, 82, 84, 96-8, 139; and Casablanca Conference 86, 90, 92; and Giraud 87-95; see also Free France, Fighting France; Gaullism, Gaullists

Delhomme, General Étienne 53

Desaché, Marc 15

Dien Bien Phu 110

Dorange, Major André 157n41

Dorgères, Henri 5, 7, 14, 16-18, 21, $144 n 83$

Dubois-Roquebert, Dr. Henri 119-20

Duhem, Édouard 148n147

Dunkirk, 4, 15, 56-7, 59, 63, 99, 151n1; 'miracle' of 56

\section{Egypt 104}

Eisenhower, General Dwight D. 66, 71-3, 75-6, 79-81, 83-4, 86, 88-9, 100, 139

L'Époque 34

Établissements Renaudat-Maroc 132

European Defense Community (EDC) 114, 120

L'Express 135

Eyraud, Émile 113-14

Faure, Edgar 127-31, 133, 135, 137

Faye, Major Léon 63

Fédération des Contribuables de la Seine 12,14

Fédération Nationale des Anciens Combattants 6

Fédération Nationale des Contribuables (Taxpayers' Federation, 1935-1939) 14 44: and big business; 14, 16-17, 145n96; and corporatism 19-21, 24; and middle-class France 22, 26-7, 42; and Paris city budget 33-40; and peasantry, political leagues, and veterans $16-18$, 22; and Popular Front politics, currency devaluation, and the Bank of France 14, 22-33; and press, public relations, and publicity 17 ; program of, 16-23; and municipal budgets of Saint-Étienne and Toulouse 39, 41-2; and tax strike 17-18, 36; see also Fédération Nationale des Groupements et Syndicats des Contribuables

Fédération Nationale des Groupements et Syndicats des Contribuables (Taxpayers'
Federation, 1928-1934) 1-14: and 6 February 1934, 12-14; and middle-class France 2-10, 13; and parliament and politics 3, 5, 6-13; and peasantry 5-9, 13-14; and political leagues $1,4,6-8$, $10,12-13$; program of $2-6,8,13$; and rallies, marches, and demonstrations 5 , 7-12; and tax strike 6-7, 9-11, 13; and veterans groups $4,6-7,11-12$; see also Fédération Nationale des Contribuables

Fédération Régionaliste Française 21

Fédération Républicaine 6

Fernand-Laurent, Jean-Camille 49, 53-5

Fez, Treaty of (30 March 1912) 101-3, 125

Le Figaro 1, 132-3

Finland 49

Forest, Louis (Louis Nathan) 144n83

Forestier, Albert 129-30, 133, 166n88

Fournier, Pierre 30-1, 97

France: Third Republic 2, 12, 14-5, 22, $56,61-2,86$; provisional government of France in North Africa 64-5, 85-9, 95-8; Fourth Republic 109, 138; sovereignty in France and the French empire 54, 60, 69, 71, 73, 84-5, 89-92, 100; see also Free France, Vichy France

Franchet d'Espérey, Marshal Louis 16

Franco, General Francisco 30

Franco-German Armistice (22 June 1940) 56,60

Franc-Tireur 133

Free France, Fighting France (La France Libre, La France Combattante) 61, 88, 92, 161n39; see also De Gaulle, French Committee of National Liberation, French National Committee

French Africa 54-5, 61-8, 71-3, 78, 81-4, 86-7, 91-5, 98-9, 139; see also High Commissionership in French Africa

French Committee of National Liberation (Comité Français de Libération Nationale, CFLN) 95-6

French Empire 54, 56, 60-2, 64, 69, 73, 84, 88-9, 94, 99-100, 105, 116

French Imperial Federation (Fédération Impériale Française) 83-5, 159n9; Imperial Council (Conseil Impérial de l'Afrique Française), then War Council, (Comité de Guerre) 83-8, 90, 92-3, 159n9, 160n17

French National Committee (Comité National Français) 87-8 


\section{The assassination of Jacques Lemaigre Dubreuil}

French North Africa seeAlgeria, Morocco, and Tunisia

French State (État Français) see Vichy France

French Union 99, 102

French West Africa 55, 57-8, 61, 66, 93; see also Dakar

Front Commun des Contribuables de Saint-Étienne 39, 41

Frossard, Ludovic-Oscar 9

Gafencu, Grigore 46

Gamelin, General Maurice 49, 51

Gaullism, Gaullists 55, 61, 70, 81, 83-4, 87, 89-90, 94-7, 116, 135, 161n40; see also De Gaulle; Free France, Fighting France

Geneva Accords on Vietnam (20 July 1954) 114

Georges-Picot, Guillaume 51

Germany 104; and France 2, 15, 26, 44, 53-63, 65-8, 70-2, 74-5, 78-80, 88, 91, $98,102,120,126,139,151 \mathrm{n} 219$, 155n10; and French Africa 57-8, 60-7, $70,72,80,98$; and Société Georges Lesieur et Ses Fils 56-9, 154n58; and Romania 45-53, 152n28, 153n35

La Gestion de la ville de Paris: le projet du budget contribuable 36

Gibraltar 66, 75-6, 79-81, 86, 158n55

Gillouin, René 38

Giraud, General Henri 67-8, 97; and Vichy 67-8, 98; and Allied landings in North Africa 60, 68-81, 138-9, 158n66, 160n17; as commander-in-chief of French forces in Africa 80, 82-5; as High Commissioner in French Africa and commander-in-chief of French land, sea, and air forces 86-9, 139; as French civil and military commander-in-chief 93-5; at Casablanca Conference 90-2; and Anfa Memorandum 91-4, 161n35; and French Committee of National Liberation 95; see also De Gaulle, Murphy-Giraud Agreement

Glawi, Abdessadek al - 121

Glawi, Thami al - 102, 106-7, 109, 121-2, 137

Goislard de Monsabert, General Jean 76-7

Goury de Roslan, Louis 49, 53-4, 145n102

Grandval, Gilbert 135-7

Great Britain 28-9, 45-6, 48, 50, 52, 55-9, $61,63,67-70,84,88-9,91-2$

Gringoire 34
Group for the Protection of Taxpayer Interests 6

Guillaume, General Augustin 107, 110

Hached, Ferhat 102

Hauteville, General Hubert d' 113

Herriot, Édouard 10, 96, 147n140

High Commissionership in French Africa (Haut Commissariat en Afrique Française) 84-6, 93, 159n11

Hirsch, Georges 38

Hitler, Adolf 15-16, 60

Hopkins, Harry 90-1, 94-5

Huileries et Savonneries du Maroc (Cotelle et Foucher) 163n1

Huileries Marocaines (Fournier-Ferrier) 97, 163n1

Huileries Réunies 100

Huiles Lesieur, see Société Georges Lesieur et Ses Fils

Hull, Cordell 87-90, 96

Hungary 49

Indochina 100, 120, 129; see also Vietnam

L'Information politique, économique et financière 100

Inter-professional Coordinating Committee of Paris Taxpayers 36, 39, 150n199

Islam 104, 122

Istiqlal (Independence Party) 101, 105, 110-11, 118, 122-5, 137; see also Morocco

Italy $45.61,64-5,98,104$

Jacquier, Paul 10

Jaurès, Jean 2

Javal, Dr. Adolphe 13, 144n83

Jeanneney, Jules 96

Jeloun, Abdel Ouahad Ben 105

Je suis partout 50

Jeunesses Patriotes 7-8, 10, 22

Jouhaux, Léon 27

Le Jour 29

Le Jour-Écho de Paris 45, 47, 49, 53-6, $59,62,64,97,128,15 \ln 1,15 \ln 219$

Le Journal 29, 34

Le Journal des débats 16-17, 39

Jousse, Colonel Louis 63, 155n15, 156n21

Juin, General (later Marshal) Alphonse xi, 120-1, 135, 157n41, 165n57, 167n106

Julien, Charles-André 113, 164n27

July, Pierre 128, 131-3, 135

Kammerer, Albert 98 
Kérillis, Henri de 34

Kirane, Ahmed Ben 105

Korchi, Si Bouchaïb Ben 135

Kula, Charles 1, 3, 15-16, 141n1

Labarthète, Henry Du Moulin de 51, 62

Labeyrie, Émile, 27, 29-31

Lacoste, Francis 111-2, 114, 119-20, 132, 134-5, 166n89, 167n91, 167n93, 167n102

Laguionie, Pierre 145n96

Lamoureux, Lucien 9, 56

Langer, William L. 61

Laniel, Joseph 110

Large, Louis-Alphonse 1, 3-4, 6-8, 10-13, $16,42,143 \mathrm{n} 59,143 \mathrm{n} 70$

Latour, François 33

Laval, Pierre 17, 56, 63, 67, 70-1, 82, 96, $155 \mathrm{n} 10$

Lavigne-Delville, General Paul de 144n87

Leahy, Admiral William D. 61, 73, 75-6, 79

Légion des Combattants Français 6-7

Lehideux, François 62

Lemaigre Dubreuil, Jacques: family background, early life, and marriage 14-15, 144n85; and Société Georges Lesieur et Ses Fils 15, 50, 56-9, 61, 97, 99-100; military service in World War I and II 14-15, 44-53, 55, 77, 144n87; and 6 February 1934 14-16; as Taxpayers' Federation president 14-44, 138; as councillor and adviser of the Bank of France 27-33, 44, 53; mission to Romania 44-53; owner of Le JourÉcho de Paris 45, 47, 49, 53-5, 59, 62, $97,15 \ln 219,15 \ln 1$; on Hitler, Nazi Germany, and Franco-German collaboration 15-16, 44, 57-9, 63-4, 154n58; and Vichy France 54-9, 62-5, $67,70,81-2,85,96-8$; and the Committee of Five and North African landings $64-81,83,89,97-8,154 \mathrm{n} 58$, $156 \mathrm{n} 28,157 \mathrm{n} 37$; as emissary and adviser to Giraud 68, 70-1, 73-7, 80-95, 98, 158n55; and Darlan 80-6; and DeGaulle 70, 82, 87-9, 92, 94-8, $161 n 39$; and Murphy 62-76, 85-7, 93-4; and Weygand 48, 51-6, 62-5; and Murphy-Giraud Agreement and Anfa Memorandum 73-6, 81-3, 85-94; on France in Morocco 100-4, 113-15, 125, 127; criticism of French policy in Morocco and reform proposals for Morocco 101-11, 114-22, 124-6, 130, 135; on terrorism and counter-terrorism
$99,110-13,118,120,122,125-35,139$; promotion of Franco-Moroccan dialogue and reconciliation 100, 104-8, $111,114,116-17,126,128,130,132-3$, 135-6, 139; owner of Maroc-Presse 128-32; and Juin xi, 120, 135, 167n106; and Mauriac xi, 102, 107, 136; and Mendès France 112, 114, 116-20, 127, 131, 134-6, 165n55; and Mohammed

Ben Youssef 100-1, 106-8, 112-14, 116, 118,137 ; assassination and funeral in Casablanca 131-5; see also Fédération Nationale des Contribuables

Lemaigre Dubreuil, Simone (née Lesieur) $15,133,135,145 \mathrm{n} 96$

Lend-Lease 69, 85

Le Provost de Launay, Gaston 36

Lesieur, see Société Georges Lesieur et Ses Fils

Lesieur, Georges 15, 144n88

Lesieur, Paul 15, 50

Lesieur-Afrique 64, 99, 116, 126; (Casablanca) 97, 99, 100, 116, 126, 164n39;

(Algiers) 99; (Dakar) 57-8, 99; see also Société Georges Lesieur et Ses Fils

Libya 66

Ligue des Contribuables de la Gironde 11

Linarès, Colonel François de 95

Lyautey, Marshal Hubert 106, 121, 125, $130,166 n 86$

Lyon 68, 74

Madagascar 68, 90, 107, 119-20, 124

Malta 66

Mammeri, Si Mohammed 119

Mandel, Georges 57

Marchandeau, Paul 56

Marin, Louis 97

Maroc-Presse 105, 118, 128-32, 136, $167 \mathrm{n} 91,167 \mathrm{n} 93$

Marseille 54, 57-8, 74, 76, 163n1

Martel, Pierre-Albin 132-3

Mast, General Charles 69-79

Mauchamp, Dr. Émile xi

Mauriac, François xi, 102, 107, 126, 135-6, $164 \mathrm{n} 27,168 \mathrm{n} 109$

Mazella, Antoine 129-30, 132-3

Mendès France, Pierre 6, 109, 112, 114, 116-20, 122-4, 127-8, 131, 134-5, 165 n55, 167n 103

Mercier, Ernest 45

Mers-el-Kébir, British attack on French fleet at (3 July 1940) 55, 61

Mierry, Colonel Joseph de 48, 51 


\section{The assassination of Jacques Lemaigre Dubreuil}

Mitterand, François 112, 164n27

Mohammed V see Sultan Sidi Mohammed Ben Youssef

Mokri, Mohammed El 119

Le Monde 106, 108-10, 113-16, 120-1, $127,132-3$

Monnet, Jean 91, 94-5, 161n34

Montrelay, Colonel Charles 77

Morocco: Allied landings in 59, 66, 71, 74, 78-80, 96; dynastic question in 114-21, 123-4, 126, 132, 137, 166n73; French policy in 100-3, 105-7, 109-14, 118, $120,124,128,131-2,136-7$; French protectorate and Residency in 57, 78, 99-103, 105-7, 109-10, 113-16, 118, $120-2,125,128-33,135-6$; independence of $100,103-4,107,110-11,117$, 122-4, 126, 137; Makhzen 103, 107, $110,118-19,121,124,126,135$; nationalism in $100,103,126$; Regency Council plans for 118-21, 123-4, 126, 137; sharifian empire in $78,116,119$; sovereignty in $111,114,116,118,120$, $122,124,133$; terrorism and counterterrorism in 98-9, 102, 107, 109-14, $118,120,122,125-36,139,164 n 35$, 166n89; and Société Georges Lesieur et Ses Fils 57, 97, 99-100, 116, 126, 163n1, 164n39; see also Casablanca, Casablanca Conference, Rabat, Sultan Mohammed Ben Arafa, Sultan Mohammed Ben Youssef

Moulay Hassan (son of Sultan Mohammed Ben Youssef) 119

Moustier, Baudouin de 128, 136-7

Moustier, Marquis Roland de 166n83

Mouvement Républicain Populaire (MRP) 134

Munich Agreement (29 September 1938) 44, 46, 51

Murphy, Robert D. 61-2, 64-6, 85, 87, 95; and preparations for Allied landings in North Africa 66-76, 78-9, 85, 87, 157n41; and Casablanca Conference 90-1; and Anfa Memorandum 91-4; see also Murphy-Giraud Agreement, Murphy-Weygand Agreement

Murphy-Giraud Agreement (2 November 1942) 73-4, 75-6, 81-3, 85-6, 88-9, 91-3, 157n45, 159n12

Murphy-Weygand Agreement (26 February 1941) 64, 155n5

Nataf, Félix 112
National Resistance Council (Conseil

National de la Résistance, CNR) 154n55

Nazi-Soviet (or German-Russian) pact (23 August 1939) 46

Noguès, General Charles 78-81, 83, 86, 96

Normandy: Allied landings in (6 June 1944) 96

North Africa see Algeria, Morocco, and Tunisia

Norway, 52

Oradour-sur-Glane 102

Oran 65,78

Oued-Zem 136

Pacific Charter (8 September 1954) 117

Parti Démocratique de l'Indépendance (PDI) 123-4, 135; see also Morocco

Patton, General George S., Jr. 80

Paxton, Robert O. 18, 22

Pearl Harbor, Japanese attack on (7 December 1941) 64

Peasant Defense (Défense Paysanne) 5, 7 , 13-14, 16-18, 144n83, 145n102

Pétain, Marshal Philippe 55-6, 59-63; 68, 71, 79-80, 84-5, 96-7, 159n11; see also Vichy France

Le Petit Marocain 131

Pétrofina Française 49; see also Société Financière Belge des Pétroles (Pétrofina)

Le Peuple 8

Peyrouton, Marcel 93, 96

Piétri, François 96

Pineau, Christian 137

Place Jacques Lemaigre Dubreuil (Casablanca) 137

Poincaré, Raymond 2, 55

Poniatowski, Prince André 90

Le Populaire 9

Popular Front 14, 22, 24, 26-30, 32, 34 , $42,44,62,147 \mathrm{n} 140,148 \mathrm{n} 146$

Port Lyautey 78

Potsdam 94

Présence Française 129

Le Progrès agricole de l'Ouest 5

Provence 75-6

Puech, André 34, 36, 38

Rabat 99, 102-3, 106-7, 109, 112, 114, $119-20,125,127,129,131-2,134,137$

Radical Socialist Party 3, 6, 10, 22, 24, 30, 97, 131, 143n47

Reber, Samuel 86-7, 89 
Reitzer, Jacques 105, 132

Les Relations franco-américaines et la politique des généraux, Alger 1940-1943 98

Réunion 90

Le Réveil du contribuable 1, 4, 6, 10, 13, $144 \mathrm{n} 84$

Revue politique et parlementaire 113

Reynaud, Paul 32, 51-3, 149n178, $150 \mathrm{n} 210$

Rhineland 26

Rigault, Jean 17, 47-9, 53-5, 62, 64-6, $68-9,83-4,86,95,135,155 \mathrm{n} 11$

Roches Noires 100

Romania 14-15, 45-54, 59, 63

Rond-Point de Mers Sultan (Casablanca) terrorist attack at (14 July 1955) 136

Roosevelt, Franklin D.: and U.S. policy on France and North Africa 61-2, 73, 82, 85, 88-92, 94-5, 100, 157n37, 157n45; and de Gaulle and Giraud 90-1, 95; and Casablanca Conference 85-6, 90-1, 100; see also Clark-Darlan Agreement, Murphy-Giraud Agreement, MurphyWeygand Agreement

Rous, Jean 133-4

Rural Alliance (Alliance Rurale) 18, $145 \mathrm{n} 102$

Russia, 15

Safi 78,131

Saint-Étienne see Front Commun des Contribuables de Saint-Étienne

Salé 99, 131

San Remo, Allied conference at (19-26 April 1920) 45

Sarraut, Albert 41

Sarret, Roger 47

Sartout, Major Henri 105, 118, 128-30, 132-3, 166n89

Schumann, Maurice 163n15

Sebti, Si Tahar 126, 129

Sefrou 105

Senegal, 15, 57-8, 64, 97, 99

Servan-Schreiber, Jean-Jacques 135

Slaoui, Omar 125

Socialist Party (SFIO) 2-3, 6, 8-9, 12, 14, $22,24,28,31,34,38-9,62,143 \mathrm{n} 47$, $144 \mathrm{n} 83$

Société des Huileries Marocaines 97, 163n1

Société d'Importation et de Répartition de Produits Oléagineux (SIRPO) 57-8

Société Financière Belge des Pétroles (Pétrofina) 49, 152n28
Société Générale des Huiles de Pétrole 50, $144 n 88,153 n 30$

Société Georges Lesieur et Ses Fils 14-16, 45, 50, 55-9, 61, 64, 97, 99-100, 116, $126,138,144 \mathrm{n} 88,145 \mathrm{n} 96,151 \mathrm{n} 1$, $153 \mathrm{n} 30,154 \mathrm{n} 58,163 \mathrm{n} 1,164 \mathrm{n} 39$

Solborg, Colonel Robert A. 63, 69-70, 73

Solidarité Française, 1, 4, 143n70

Soussi, Abbed 105

Soviet Union (USSR) 49, 63, 122

Spain 29-30, 63, 96

Stavisky scandal 12, 144n90

Switzerland 67

Syndicat des Contribuables Parisiens 11-12

Tangier 66, 119

Tarbé de Saint Hardouin, Jacques 64, 83, 86

Tardieu, André 6

Taxpayer Defense League (Ligue de Défense des Intérêts du Contribuable) 1

Taxpayers' Federation see Fédération Nationale des Groupements et Syndicats des Contribuables and Fédération Nationale des Contribuables

Teheran 94

Le Temps 9

Tetouan 109; Caliph of 119-20

Thierry, Adrien 48-52, 55

Times (London) 132

Togo 123

TORCH, Allied landings in French North Africa (8 November 1942) 59, 70-6, 78, $157 \mathrm{n} 36,157 \mathrm{n} 37$; see also Algeria and Morocco

Torchaussé, Henri 27

Toulon 72, 80

Toulouse: taxpayer protest in 39,42 , $15 \ln 216$

Tunis 54, 114, 137

Tunisia $71,80,98,102,114,117-18,120$, $126-7,158 \mathrm{n} 55$

Union Nationale des Combattants 7

United States 2, 46, 50, 58-9; and Vichy France 61-2, 65-6, 71, 82, 95, 157n37; and French Africa 61-98, 157n37, 157n41; and French Morocco 100-1, $103,105,114,122,163 n 4$

Van Hecke, Colonel Jean 65, 69, 83

Varinot, Louis 14

Versailles, Treaty of (28 June 1919) 45

Vichy France 44, 50, 53-6, 60-5, 67-8, 


\section{The assassination of Jacques Lemaigre Dubreuil}

$71,77,79,82,86,88,92-8$; and French Africa 57-61, 63-4, 66, 71, 78-81, 84-6, 94-6, 98; and Allied landings in North Africa 78-81, 157n37; and

Société Georges Lesieur et Ses Fils 50, 57-9, 61, 154n58; see also Darlan, Laval, Pétain

Vichy government see Vichy France

Vidal de la Blache, Paul 21

Vietnam 110, 112, 114; see also Indochina Vigerie, General François d'Astier de la 87 Vigerie, Lieutenant Henri d'Astier de la 65,83

Walter, Jacques 128-9

Welles, Sumner 66-7

Wendel, François de 97

Wenger, Léon 47, 49-51, 53
Weygand, General Maxime 48, 51-6, $61-6,68,78,84$

Wiesbaden 58; Franco-German vegetable oil accords at $154 \mathrm{n} 60$

Wohlthat, Helmut 47

Wybot, Roger 166n89

Yalta 94

Youssef, Sultan Sidi Mohammed Ben (Mohammed V) 78, 100, 165n57; and revision of Treaty of Fez 100-3, 105; dethronement and exile 106-8, 110-11, 113-16, 123, 136; national support for $101,107-8,110,112,114-15,118,123-5$, 136; and Regency Council plan 119-20, 123-4, 137; restoration $112,120-1,137$

Zeghari, M'hamed 105, 113 


